

Stacey Triplette

\title{
Chivalry, Reading, and Women's Culture in Early Modern Spain
}

\section{From Amadís de Gaula to Don Quixote}


Chivalry, Reading, and Women's Culture in Early Modern Spain 


\section{Gendering the Late Medieval and Early Modern World}

Series editors: James Daybell (Chair), Victoria E. Burke, Svante Norrhem, and Merry Wiesner-Hanks

This series provides a forum for studies that investigate women, gender, and/ or sexuality in the late medieval and early modern world. The editors invite proposals for book-length studies of an interdisciplinary nature, including, but not exclusively, from the fields of history, literature, art and architectural history, and visual and material culture. Consideration will be given to both monographs and collections of essays. Chronologically, we welcome studies that look at the period between 1400 and 1700, with a focus on any part of the world, as well as comparative and global works. We invite proposals including, but not limited to, the following broad themes: methodologies, theories and meanings of gender; gender, power and political culture; monarchs, courts and power; constructions of femininity and masculinity; gift-giving, diplomacy and the politics of exchange; gender and the politics of early modern archives; gender and architectural spaces (courts, salons, household); consumption and material culture; objects and gendered power; women's writing; gendered patronage and power; gendered activities, behaviours, rituals and fashions. 


\title{
Chivalry, Reading, and Women's Culture in Early Modern Spain
}

From Amadís de Gaula to Don Quixote

\author{
Stacey Triplette
}


Cover image: Vittore Carpaccio, The Virgin Reading, c. 1505. Oil on panel transferred to canvas. Samuel H. Kress Collection, National Gallery of Art

Cover design: Coördesign, Leiden

Lay-out: Crius Group, Hulshout

Amsterdam University Press English-language titles are distributed in the US and Canada by the University of Chicago Press.

$\begin{array}{ll}\text { ISBN } & 9789462985490 \\ \text { e-ISBN } & 9789048536641 \\ \text { DOI } & 10.5117 / 9789462985490 \\ \text { NUR } & 617 \mid 694\end{array}$

(c) S. Triplette / Amsterdam University Press B.V., Amsterdam 2018

All rights reserved. Without limiting the rights under copyright reserved above, no part of this book may be reproduced, stored in or introduced into a retrieval system, or transmitted, in any form or by any means (electronic, mechanical, photocopying, recording or otherwise) without the written permission of both the copyright owner and the author of the book.

Every effort has been made to obtain permission to use all copyrighted illustrations reproduced in this book. Nonetheless, whosoever believes to have rights to this material is advised to contact the publisher. 


\section{Acknowledgements}

One of the most valuable things I have learned during the process of writing this book is that good writing requires good friends. While many people have assisted me on my quixotic forays into the world of chivalry, I would like to mention a few who made that journey more rewarding. First, I would like to thank Ignacio Navarrete for putting Amadis de Gaula on his syllabus and for being the best dissertation director I could have imagined. I thank Emilie Bergmann and Albert Ascoli for their perspective on my writing and their excellent questions, and I thank Anthony Cascardi, Tim Hampton, Jesús Rodríguez-Velasco, José Rabasa, Soledad Miguel-Prendes, Olga Valbuena, and the late James Nicolopulos for shaping my thinking on the early modern world.

I also thank the colleagues and friends who have supported me through writing this book, including Mark Lynn Anderson, Elizabeth Archibald, Lynn Arner, Andrew Barnette, Greg Bondar, Bill Campbell, Jim Coleman, Sheila Confer, Elizabeth Contreras, Alicia Covarrubias, Anne Czerwinski, Neil Doshi, Kenya Dworkin, Amanda Folk, Rémi Fontanel, Rebecca FutoKennedy, Pilar Herr, Elisabeth Hodges, Amy Hubbard, Katherine Ibbett, Lina Insana, Lori Jakiela, Aaron Kahn, Renee Kiner, Martha Koehler, Olivia Long, Lowry Martin, Amber McAlister, Tom McWhorter, Giuseppina Mecchia, Steve Murabito, Sarah Rackley Olson, Silvina Orsatti, Russ Phillips, Bill Rued, Audrey Sartiaux, Francesca Savoia, Stephen Schrum, Laurel Parker Simmons, Linda Troost, Gretchen Underwood, Luc Vancheri, John Walsh, and the members of Humanities Professors Group 5 at the Academic Writing Club. I owe special thanks to those who read my book proposal or parts of the manuscript: Elisa Beshero-Bondar, Renate Blumenfeld-Kosinski, Patrick Bray, Julia Farmer, Maggie Flinn, Sayre Greenfield, Chloé Hogg, Christina Lee, Todd Reeser, and Sam Ruhmkorff.

I am also grateful to the Pitt-Greensburg administrators who have supported this project, including Jacqueline Horrall, Wes Jamison, and Sharon Smith. I thank my wonderful Pitt-Greensburg students, especially research assistants Madison Bredice and Rebecca Parker. I also thank Amsterdam University Press and the series editors for Gendering the Late Medieval and Early Modern World: James Daybell, Victoria Burke, Svante Norrhem, and Merry Wiesner-Hanks. In particular, I would like to thank acquisitions editor Erika Gaffney for shepherding this book through the review process with kindness and expertise. I am also grateful to the peer reviewers for the manuscript, whose thoughtful feedback helped me improve my work. 
I thank my family for supporting my pursuit of language, literature, and culture. I am grateful to my parents for encouraging me to study abroad in Spain, and to my brother, Matt, for helping me think through the world's problems. Lastly, I thank my husband, David Pettersen, my first and best reader. Thank you for reality checking my ideas and encouraging me to follow the good ones. Thank you for believing in this project even when I had my doubts. This book exists because of you. 


\section{Table of Contents}

Introduction

1. Women's Lives and Women's Literacy in Amadís de Gaula

2. Women's Literacy in Beatriz Bernal's Cristalián de España

3. The Triumph of Women Readers of Chivalry in Don Quixote Part I 117

4. The Defeat of Women Readers of Chivalry in Don Quixote Part II

153

Conclusion

Bibliography

Index

\section{Illustrations}

Figure 1 Woodcut of Amadís fainting after entering Arcaláus's dungeons, surrounded by ladies, one of whom is reading a book. From the 1519 Rome edition published by Antonio de Salamanca.

Figure 2 Woodcut accompanying the chapter with Amadís's erotic liaison with Oriana. Amadís leads Oriana by the hand while her maid looks on, modeling the affective response the scene should elicit from its readers. From the 1533 Venice edition published by Juan Antonio de Sabia.

Figure 3 A messenger reports to Oriana. From the 1526 Sevilla edition of Amadís de Gaula by Jácome Cromberger.

Figure 4 Oriana writes to her mother. From the 1526 Sevilla edition of Amadís de Gaula by Jácome Cromberger. 



\section{Note to the Reader}

In this book I cite primary sources in both the original language and in the English translation wherever possible. I have translated citations from secondary sources into English. In all cases, translations are my own unless otherwise noted. Many of the primary sources I cite reflect medieval and early modern conventions for spelling and punctuation. When I cite from a critical edition, I follow the editor's version of the text, including any modernizations. When I cite directly from an early modern book, I modernize capitalization, punctuation, the division and separation of words, and the distribution of letters $\mathrm{i}, \mathrm{u}, \mathrm{v}, \mathrm{j}$, and $\mathrm{y}$. 



\section{Introduction}

Mi raviosa quexa acompañada de sobrada razón da lugar a que la flaca mano

declare lo que el triste coraçón encubrir no puede contra vos el falso y desleal cavallero Amadís de Gaula, pues ya es conoçida la deslealtad y poca firmeza que contra mí, la más desdichada y menguada de ventura sobre todas las del mundo,

havéis mostrado

(My furious complaint accompanied by more than enough reason causes my weak hand to declare what the heart cannot conceal to you, most false and disloyal knight Amadis of Gaul; it is now well known what disloyalty and little constancy you have shown to me, the most wretched and least fortunate woman in the world)

- Garci Rodríguez de Montalvo, Amadís de Gaula

In Book II of Amadis de Gaula (1508), Oriana, the princess of Britain, writes an angry letter to her lover, Amadís, telling him never to come near her again. Oriana's famous letter, from which I drew the epigraph, reveals the unexpected role women's literacy plays in the plot of Amadis and the other early modern Spanish texts that imitated it. While men do almost all the fighting in early modern Iberian romance, women do much of the writing. Battles occupy many pages, but letters and prophecies, both of which tend to originate with women, flow between and around them. Interpolated texts attributed to women link characters across distance and open a space for personality, interiority, and emotion in the narratives. In this book, I contend that the interior worlds of Iberian chivalry and the women characters who shape them create a ripple effect that can be felt, even to the present day, in works of fiction that borrow from Iberian romance.

The literary fortunes of Oriana and her letter encapsulate in miniature the power and the ambivalence of Iberian chivalry's fictionalized women. Oriana is a hybrid creation, part medieval señora of courtly love and part early modern queen in the style of Isabel la Católica. ${ }^{2}$ Garci Rodríguez de Montalvo, the editor-compiler of the early modern Amadis, characterizes her as cruel at some moments and admirable at others. Yet it is precisely

1 Rodríguez de Montalvo, Amadís de Gaula, I: 676-77. All translations are my own unless otherwise noted.

2 For the connections between Oriana and Isabel, see Cuesta Torre, 'Realidad histórica', 106; Lobato Osorio, 'El auxilio a Oriana', 130; Triplette, 'From Guinevere to Isabel'. 
Oriana's complexity, her combination of virtues and flaws, that renders her worthy of sustained consideration. A beautiful aristocrat with an adoring lover, seemingly impervious to the predations of giants, enchanters, and Roman emperors, Oriana wields power in her own right and acts on her world through the written word. She commits repeated infractions against chastity and good sense, but her affair of the heart leads to triumph, not shame.

Negative commentary about Oriana in the conduct tradition suggests that she had considerable appeal for readers. Francisco Cervantes de Salazar warned in 1546 that women readers of the romance would want to become 'otra Oriana [...] servida de otro Amadís (another Oriana ... served by another Amadís).'3 Though Salazar worried primarily about women's chastity, I argue in this book that many found chivalric romance to be a threat because the genre suggested strategies through which literate women might subvert social norms. While it would be impossible to know exactly how each reader responded to the literate female characters of Iberian chivalry, the long history of these characters in imitation, translation, and adaptation, both in Spain and in other countries, suggests their potency and influence.

This book collects many moments like Oriana's letter and uses them to re-evaluate the place of women in Iberian chivalric fiction. Because the female characters of Iberian romance are less numerous and more confined than male characters, it has been relatively easy to miss their contributions to the genre, especially in previous centuries, when misogynist readings could be presented without question. Though the obvious lessons of Iberian chivalry are directed at men and masculinity, the romances issue a call to women as well. Early modern Spanish chivalric narratives teach their male audience that if they serve God, king, and country according to an archaic but compelling chivalric code, social mobility will be their reward. ${ }^{4}$ In turn, the romances show female readers how to use literacy as a lever of resistance. Though the authors who represented the female characters discussed in these pages were predominantly male and often echoed misogynist discourse, they do not subject female characters uniformly to the dominion of men. Female chivalric characters continually flaunt social norms and escape punishment, and even if the author protests in an aside, the genre suggests that the rules can be broken. Indeed, the early modern female writer Beatriz Bernal was able to find inspiration for egalitarian views on

3 Cervantes de Salazar, 'Introducción y camino para la sabiduría', f. 14r; qtd in Gagliardi, Urdiendo ficciones, 210.

4 Rodríguez Velasco, 'Fábula caballeresca', 357. 
gender in Amadis and other male-authored chivalric texts. In gathering a series of exceptions to the stereotypes about Iberian romance, I show how literate female characters offered a relatively progressive perspective on women and, in doing so, contributed to the development of trends in fiction that would later become associated with the modern novel.

In the texts I discuss, female characters are insistently literate, and their literacy serves as an index - if an equivocal one - for the degree of agency they are able to exercise. Many of the cherished tropes of chivalry, including its famous erotic plots, require the participation of women. Chivalric romance does not require women's silence, and thus, to a degree, the genre enables women's agency. Though the literate women of chivalry offer limited resistance to gendered codes of behavior, there is a degree of subversion involved in their choices: writing is always less circumspect than refusing to communicate. Oriana's missive, for example, is one such act of rebellion, and it took on a life of its own, both within Amadis and in the hands of historical readers. Amadís the character receives a quasi-physical blow to the heart when he reads the letter, and other characters, the intrusive author Montalvo, and even literary critics must scramble to prove his innocence. Oriana's messenger soon reports that Amadís has passed through the magical Arch of Loyal Lovers, so he must have been faithful after all. Oriana's jealousy, therefore, must be irrational. Most critics, even today, accept that view, and some forcefully reaffirm it. ${ }^{5}$ Yet Oriana's jealousy could be thought of as logical considering the information she received, and in fact, some medieval versions of the story attest to Amadís's guilt. ${ }^{6}$

As Amadis traveled through the European literary market, readers imitated, interpreted, and rewrote Oriana's letter as they pondered the concepts of gender and power. In Beatriz Bernal's 1545 Cristalián de España, the character Penamundi channels Oriana's ire when she writes to Cristalián, even though his crime-concealing his identity from a new acquaintance-is minor. By citing Oriana, Penamundi declares her dominion over her suitor. In Part I of Don Quixote (1605), Oriana's diction and tone surface in Cardenio's unsent letter to Luscinda. The citation reverses the gender polarities of the episode, drawing into question misogynist readings of Oriana. Cervantes places Cardenio in the pose of the irrationally jealous

5 See Rodríguez de Montalvo, Amadís de Gaula, I: 670; Eisenberg, Romances of Chivalry, 78; Aguilar Perdomo, 'La penitencia de amor caballeresca', 191; Lucía Megías, 'Los cuatro libros', 98. 6 For versions of the story in which the knight succumbed to rival queen Briolanja's lewd advances, see Rodríguez de Montalvo, Amadís de Gaula, I: 612-13; Avalle-Arce, El Amadís primitivo y el de Montalvo, 163. 
lover, emphasizing that being mistaken is not the exclusive province of women. Nicolas de Herberay's 1540 French translation, which is otherwise free in its relationship to the source text, produces a version of the letter faithful to Oriana's words. It contains recognizably the same content as in Montalvo's edition, with cognates for the Spanish diction and no embellishments, changes of tone, or omissions. Herberay's printer Janot likewise considers Oriana's missive special, as he distinguishes it from the surrounding romance with margins and white space of a kind twenty-first-century readers take for granted but which were not present in previous printings of the letter. In 1590, Anthony Munday published an English translation of Herberay's Amadis in which he reproduces Oriana's letter nearly word for word. 7 The digest Le Trésor des Amadis (The Treasury of the Amadis, 1560), with a contrasting technique, characterizes Oriana's words as a formulary for wounding others, thereby reducing their meaning to an act of cruelty. ${ }^{8}$ The Trésor follows Oriana's missive with an apocryphal complaint letter from Amadís to his father in an attempt to reassert gender polarities. The Trésor thus seeks to contain Oriana's ability to command. Other versions of this episode take the Trésor's technique one step further and omit the text of Oriana's letter entirely. Both Gil Vicente's 1533 Amadís play and Jean-Baptiste Lully's 1684 opera dramatize the sadness Amadís feels upon receiving the missive, without adapting any of the letter's words. ${ }^{9}$ The public watches Amadís suffer without learning the cause, and the effect is hollow. The different strategies imitators and translators used in their adaptations of Oriana's letter point to the gendered question at the heart of the romance of chivalry: To whom do the romances belong - men, women, or both?

This book argues that the romances indeed belonged to readers of both genders in the early modern period, in part because their structure allowed multiple viewpoints on gender to coexist. All Iberian chivalric romances demonstrate inconsistencies that arise from their interlaced structure, and Amadis - written at different times by different writers-is an extreme example. Moments structured around women offer a set of significant exceptions to the masculine-oriented rules of Iberian romance. This study classifies such interludes as instances of women's culture. I adapt this term from Elaine Showalter, who proposes a culturally based feminist theory that 'incorporates ideas about women's body, language, and psyche but interprets them in relation to the social contexts in which 
they occur'. Showalter, citing Gerda Lerner, emphasizes 'experience that binds women writers to each other over time and space..$^{10}$ For the purposes of this book, I define women's culture as the life stories of women, the spaces they inhabit, and the texts they create. These moments, ruled by interpolated texts, allow glimpses into the interior and family lives of female characters-concerns that will become important in the modern novel for both genders.

Chivalry, Reading, and Women's Culture tracks literate female characters within Amadis de Gaula and then follows their legacy in other works of Spanish literature. The objects I study span the sixteenth to the twenty-first centuries, with a gap corresponding to the decline in Amadis's reputation that has been noted by Daniel Eisenberg and others. ${ }^{11}$ The authors treated in these pages, however, are not the only writers who have responded to Amadis throughout its long textual history; indeed, the adaptations and imitations, both in Spain and beyond, are too numerous to be accounted for under a single framework. I have chosen to focus on those Spanish authors who celebrate literate female characters, but throughout the book, I mention in passing others who took a more normative view of women. In addition, it must be said that Amadis is not the only influential or popular Iberian romance that featured capable women; a parallel story could be told through Tirant lo Blanch or Palmerín. Amadís de Gaula, however, is a fitting central object for this study, as it was the most-reprinted and most-cited of the early modern Iberian romances. For Don Quixote, Amadís was 'el norte, el lucero, el sol de los valientes y enamorados caballeros (the polestar, the morning star, the sun to valiant, enamored knights)'. The fact that much of the early modern audience perceived Amadís in this exemplary manner was key to its market appeal and its imitation and adaptation. ${ }^{12}$ Although over the course of the sixteenth century, Spanish intellectuals advocated ever-greater restriction of women's behavior, Amadis, which dates from an earlier cultural moment, survives as a counter-narrative in which women are visible, numerous, intellectually equal to men, and capable of changing their circumstances via the written word. ${ }^{13}$

10 Showalter, 'Feminist Criticism in the Wilderness', 197.

11 Eisenberg, Romances of Chivalry, 48.

12 Cervantes Saavedra, Don Quijote, I, 25; 303; Cervantes Saavedra, Don Quixote, 193.

13 Emilie Bergmann, 'The Exclusion of the Feminine in the Cultural Discourse of the Golden Age', 125; Grieve, 'Mothers and Daughters in Fifteenth-Century Spanish Sentimental Romance: Implications for Celestina', 345 . 


\section{The Amadis Phenomenon}

Few texts in European literary history were as famous as Amadis de Gaula in their own era and as neglected thereafter. Amadis, the oldest version of which is thought to date to the fourteenth century, chronicles the entwined stories of a young knight of unknown parentage and his secret bride, the British princess Oriana. The couple's clandestine liaison produces a son, Esplandián, and the medieval legend concludes in tragedy, with Amadís's accidental death at Esplandián's hands and Oriana's suicide. ${ }^{14}$ At the end of the early modern version, the lovers marry publicly and assume British rule in Oriana's father's stead. In the last decade of the fifteenth century, Garci Rodríguez de Montalvo, a nobleman and city official from Medina del Campo, edited and compiled the romance as we know it today. Yet Amadis remains, quite evidently, a multi-author text, as Montalvo's commentary draws attention to episodes he changed or added.

Soon after its first publication, Amadís became one of the most dramatic success stories of the emergent print market in Europe. At least eighteen editions of the romance were published in Spain between 1508 and 1650 , and translations soon followed in Italian, French, Portuguese, English, Dutch, and Hebrew. ${ }^{15}$ Amadis enjoyed three distinct early modern vogues in which citations, imitations, translations, and adaptations proliferated. The first of these waves tracks to the mid-sixteenth century in the Iberian Peninsula, France, and Italy. In addition to inspiring nine sequels by five writers in Castilian, Amadís gave rise to Portuguese playwright Gil Vicente's 1533 Amadís de Gaula, a 1540 French translation by Nicolas de Herberay that reached an even wider audience than Montalvo's text, and an epic poem, Amadigi di Gaula (1560), by Torquato Tasso's father, Bernardo.$^{16}$ Amadis fell out of fashion in Spain during the reign of Felipe II (1556-1598), and in France the popularity of Herberay's translation declined after the 1559 death of Henri II in a chivalry-inspired tournament. ${ }^{17}$ Amadis enjoyed a revival in English translation in the first quarter of the seventeenth century, and at the same time it resurfaced in Spain via Cervantes's Don Quixote, if only as a subject of mockery. Amadis-related texts became relevant again during the reign of Louis XIV in France, lending metaphorical support to

\footnotetext{
14 Lida de Malkiel, Estudios, 151.

15 Chevalier, Lectura y lectores, 69.

16 Marian Rothstein gives what she terms a conservative estimate of 500,000 readers of the French Amadis de Gaule, rendering it the king of literary works in translation for its century. See Rothstein, Reading in the Renaissance, $\mathrm{v}$.

17 La Noue, Discours politiques et militaires, 134.
} 
the absolutist rule of the Sun King in not one but two royally commissioned operas. ${ }^{18}$ Each time Amadís declined, it re-emerged later in a different language, genre, or context. It might be argued that Amadís has recently begun to enjoy yet another afterlife, just past its five-hundredth year, as it has become a subject of renewed scholarly interest, both in connection with and independent of Don Quixote.

During its periods of popularity, Amadis took hold of its readers' imaginations in ways that overspilled the printed page. In the sixteenth century, Amadis impacted courtly behavior, aristocratic letter-writing conventions, and even the study of French as a second language. ${ }^{19}$ Editions of the work ranged from luxurious folio volumes that mimicked illuminated manuscripts to the tiny Belgian edition of the Trésor des Amadis (1560), a digest small enough to fit inside a sleeve cuff. Owning an Amadís, especially in France, could be a point of pride, signaling the possessor's wealth, good taste, and opportunities for leisure. ${ }^{20}$ Amadís appeared on both sides of the Pyrenees as a character in tournaments and masques, and courtiers used names from Amadís-themed romances as pseudonyms in their love letters and as names for their pets. ${ }^{21}$ The territory of California in the New World took its name from Las sergas de Esplandián, a sequel to Amadís, and one intrepid Spanish ambassador even dared to compare Queen Elizabeth I to Amadís's lover, Oriana. ${ }^{22}$ The readership of Amadis included women as well as men and crossed class boundaries. Though the world represented in the text was aristocratic, its high degree of abstraction from Castilian history and politics enabled a broad, international appeal. ${ }^{23}$

Yet even in the sixteenth century, some readers objected to Amadis on moral and aesthetic grounds. To properly understand the women of Amadis, it is essential to grasp the ambivalence of the work's reception from its first publication to the present day. Amadís has often been celebrated for its excellence and condemned for its bad style, sometimes by the same writer, and it is among the more polarizing works of Iberian literature. One of the reasons for this uneven reception is that the text already seemed archaic to its earliest print audiences. The libro de caballerías ('book of

18 The first, by Jean-Baptiste Lully, was performed at the Paris Opera and at Versailles in 1684 . The king commissioned a second Amadís-themed opera by André Cardinal Destouches in 1699.

19 Marín Pina, Páginas, 85; Rothstein, Reading in the Renaissance, 41.

20 Rothstein, Reading in the Renaissance, 40; Krause, Idle Pursuits, 121.

21 Chevalier, Lectura y lectores, 80-83.

22 Rodríguez de Montalvo, Las sergas de Esplandián, 728; Vogeley, 'How Chivalry Formed the Myth of California', 165; Avalle-Arce, El Amadís primitivo y el de Montalvo, 60.

23 Chevalier, Lectura y lectores, 70-98. 
chivalry') in Spain was primarily an early modern phenomenon, but the texts' language, customs, and politics felt medieval. ${ }^{24} \mathrm{Amadis}$ 's twelfth- and thirteenth-century French antecedents reached the Iberian Peninsula via troubadour poetry and the pilgrim's road to Santiago de Compostela, and the text presents itself as a prequel to the stories of King Arthur. ${ }^{25}$ Though the romance reflects the influence of the prose Lancelot at the level of structure and motif, its plot is unique and likely of Castilian origin. ${ }^{26}$ Some sixteenth-century readers appreciated Amadis's medievalizing tendencies, but others lamented its hybrid of medieval and early modern language and frequent lapses of verisimilitude.

The medieval European romance of chivalry, of which Amadís is a clear descendant, contains subtypes in poetry and prose and organizes itself according to three overarching themes: the Arthurian matter of Britain, the Carolingian matter of France, and the classical matter of Rome. With some exceptions, individual chivalric volumes tend to focus on a hero related to one of these three broad genealogies, often promoting a previously minor character to a starring role. Romances are not strictly tied to the nation-states in which they were written; many of the oldest Arthurian texts were written in French, and Carolingian hero Roland took his most popular form in Italian poet Ludovico Ariosto's Orlando Furioso (The Frenzy of Orlando, 1516). Early modern writers, including Sir Thomas Malory, Ariosto, and Montalvo, often rewrote medieval texts, and the most famous versions of a story are often the most belated. Chivalric romance distinguishes itself from other forms of narrative fiction in its nostalgic view of the past; its emphasis on courtesy, masculine honor, and ritual; and its favorable attitude toward magic and other non-verisimilar motifs. At times, however, it shades close to other genres: Italian varieties share much with epic, including poetic form, and the early modern Spanish romances resemble the sentimental novel except in their length. Women participate in chivalric romance as partners in love affairs, sorceresses wicked and benign, and equivocal emblems of power and weakness. Queens like Guinevere and Isolde are balanced with damsels in distress, named and unnamed, who exist to be the victims of the monsters who stalk a hostile landscape and, on occasion, of the knights who ride to their rescue.

24 Riquer, Estudios sobre el Amadís de Gaula, 13; Gutiérrez Trápaga, Rewritings, Sequels, and Cycles, 6 .

25 Lida de Malkiel, 'Arthurian Literature', 405; Gil-Albarellos, Amadís de Gaula y el género caballeresco en España, 32.

26 Harney, 'Spanish Lancelot', 190; Sharrer, 'The Acclimatization of the Lancelot-Grail Cycle in Spain and Portugal', 186; Lida de Malkiel, 'Arthurian Literature', 415; Bamford, 'Fragment as Phenomenon', 50. 
Though Amadis was among the most important books of the sixteenth century for those who lived it, the chivalric genre has largely been omitted from the history of the novel as it has been told in Spain. Beginning with the reign of Felipe II, elite cultural circles began to exclude medieval forms of narrative in favor of literary genres that presented themselves as historical, verisimilar, or grounded in classical allusion. ${ }^{27}$ Until the late twentieth century, criticism of Amadis echoed the qualms of sixteenth-century moralists about entertainment-oriented literature in general and chivalry in particular. For example, Marcelino Menéndez y Pelayo, writing at the turn of the twentieth century, considered chivalric romance an aberration in literary history rather than a fundamental link between medieval and modern fiction. ${ }^{28}$ Menéndez y Pelayo provided a rich resource for other scholars by collecting disapproving sixteenth- and seventeenth-century critical commentary on Amadís and texts like it. ${ }^{29}$ His citations of Juan Luis Vives, Melchor Cano, Alexio de Venegas, Fray Pedro Malón de Chaide, Pedro Mexía, Antonio de Guevara, Alonso de Fuentes, and Fray Luis de Granada make clear that even at the peak of Amadis's popularity in Castile, prominent thinkers considered chivalric romance poor reading material for anyone and especially dangerous for women..$^{30}$

Menéndez y Pelayo's book also constrained later criticism on Amadís by reinforcing what Barbara Weissberger terms an arbitrary divide between the 'masculine' chivalric romance and the 'feminine' sentimental romance. ${ }^{31}$ Even in the mid-twentieth century, which saw renewed enthusiasm for Amadis, the romance was often assessed in isolation from other genres or national literatures. The new interest in Amadis in the twentieth century owed largely to Antonio Rodríguez Moñino's 1955 manuscript find, which uncovered fragments of a pre-Montalvo Amadis and indicated that the legend most likely originated in Castile. ${ }^{2}$ Translators and scholars of earlier centuries had often speculated, in earnest or in jest, that the romance might have a Portuguese or French origin. That Amadís could be said with some confidence to be Castilian encouraged the study of it in the national interest of Spain. Indeed, much of the best twentieth-century work on

27 Gutiérrez Trápaga writes that of the 87 unique romances of chivalry published in sixteenthcentury Spain, two thirds appeared before 1551. See Gutiérrez Trápaga, Rewritings, Sequels, and Cycles, 4 .

28 Menéndez y Pelayo, Orígenes de la novela, 1: 275 .

29 Ibid., 1:266-70.

30 Ibid.

31 Weissberger, 'The Gendered Taxonomy of Spanish Romance', 211-12.

Rodríguez-Moñino, El primer manuscrito del Amadís de Gaula, 15-24. 
Amadís situates the text within Spanish history. Martín de Riquer identified mentions of Amadís in Castilian poetry dating to as early as $135^{0.33}$ Other critics, including Frank Pierce and Juan Bautista Avalle-Arce, used textual clues to distinguish the 'primitive' text from the contributions of Montalvo. ${ }^{34}$ While the lost medieval Amadis is not the focus of this book, these studies offer an interesting counterpoint for this project as they propose theories about how and why chivalric fiction changes over time. By contrast, Chivalry, Reading, and Women's Culture takes a forward-looking approach, emphasizing Amadis's impact on the subset of Spanish readers who reinterpreted its women.

This book's attention to Amadís and its afterlives also seeks to revise the longstanding line of criticism connecting the romances of chivalry to Don Quixote. To study Cervantes's novel is to study Amadis de Gaula, either directly or indirectly. René Girard writes that for Don Quixote, 'chivalric existence is the imitation of Amadis in the same way that the Christian's existence is the imitation of Christ'.35 Yet, with good reason, many scholars view Cervantes as categorically hostile to chivalry; after all, reading chivalry provokes such profound madness in the title character that death is the only remedy. Some critics read Don Quixote as the eulogy of Amadis, and others have constrained their treatment of chivalric romance to the volumes found in the mad hidalgo's library. ${ }^{36}$

Yet other studies of the connection between Amadis and Quixote, such as Edwin Williamson's The Halfway House of Fiction:Don Quixote and Arthurian Romance and Howard Mancing's The Chivalric World of Don Quixote, discuss the ways in which Cervantes's use of the romance of chivalry could be understood as an homage, if an equivocal one. As Williamson and Mancing have noticed, the notion that Cervantes would write to defeat the romance of chivalry does not entirely make sense. ${ }^{37}$ Daniel Eisenberg observes that the popularity of chivalric romance had already declined so sharply by the time of Don Quixote that the phenomenon needed no additional support. ${ }^{8}$ I argue in this book that Cervantes, writing at the turn of the seventeenth

34 Pierce, Amadís de Gaula, 15-70; Avalle-Arce, El Amadís primitivo y el de Montalvo, 119-32.

35 Girard, Deceit, Desire, and the Novel, 3.

36 Entwistle, The Arthurian Legend, 231; Eisenberg, Romances of Chivalry, xvii.

37 In the prologue to Part I, the amigo of the fictionalized author persona advises: 'llevad la mira puesta a derribar la máquina mal fundada destos caballerescos libros, aborrecidos de tantos y alabados de muchos más'. I join other critics in reading this phrase as ironic. See Cervantes Saavedra, Don Quijote, I: 58 .

38 Eisenberg, Romances of Chivalry, 48. 
century, transformed the motifs and character archetypes of the medieval genre in order to incorporate them into the hybrid literary form that would later come to be known as the novel. Don Quixote thus inaugurated the literary lineage that guaranteed Amadis its longest and most flexible afterlife.

Recent scholars, following Eisenberg's call to revive the study of the genre, have worked to broaden the context in which readers understand Iberian chivalric romance. ${ }^{39}$ Michael Harney has analyzed the family groups of Amadís and other Iberian romances, and Diana de Armas Wilson has shown how the mindset of chivalric romance influenced the conquest of the Americas. ${ }^{40}$ In keeping with that trend, Jesús Rodríguez Velasco has examined literary chivalry in dialogue with the historical tension among social classes, and Simone Pinet has discussed European concepts of cartography and geography in connection with the allegorical spaces of both Amadis and Don Quixote. ${ }^{41}$ Marian Rothstein and Elizabeth Spiller, meanwhile, have explored the fate of Amadis in France and England. ${ }^{42}$ Rothstein's and Spiller's studies share with this book the notion that Amadis offers an extraordinary opportunity to study the relationships among texts and readers in the early modern period. ${ }^{43}$ Cervantes, the most prominent reader of chivalry in my list, has always been a major player in Spanish literary history, but Beatriz Bernal and Rosa Montero are rarely connected to the story of the novel in Spain at all. Yet Cervantes, Bernal, and Montero all have one important factor in common: their literary works prove them to be readers, if not always fond readers, of the romance of chivalry, and they adapt female chivalric characters in ways that expand upon their literacy and agency.

\section{Women Readers of Chivalry}

Though moralists contemporary to Amadis observed that women read romances, most scholars up to the present day have assumed that chivalry's primary readers were men. This book highlights the presence of female readers of romance-historical and fictionalized - who respond to specific features of Amadis. This is not the first study, however, to discuss female characters in chivalric romances or female writers of chivalric texts. María

Harney, Kinship; Wilson, Cervantes, the Novel, and the New World.

Rodríguez Velasco, Order and Chivalry; Pinet, Archipelagoes.

2 Marian Rothstein, Reading in the Renaissance; Spiller, Reading; Spiller, 'Cervantes'.

Rothstein, Reading in the Renaissance; Spiller, Reading, 114. 
Carmen Marín Pina's Páginas de sueños contains a chapter on the intradiegetic letters attributed to women in Iberian romances, and Donatella Gagliardi's Urdiendo ficciones introduces sixteenth-century chivalric writer Beatriz Bernal to modern audiences. ${ }^{44}$ Marian Rothstein's Reading in the Renaissance, meanwhile, describes the popularity of the translated Amadis de Gaule among French women, and Elizabeth Spiller's Reading and the History of Race in the Renaissance includes female characters among its objects of study. While my book draws on work by these critics, the focus here is different. I use fictional representations of women and instances of intertextuality to explore the possibilities of romance reading among a female public in Spain. By following a single influential romance, Amadis de Gaula, on the pathways it traveled through other works, I am able to make inferences about the related trajectories of women's readership.

In sixteenth-century Spain, many women were readers, writers, and book owners, yet as Anne J. Cruz observes, women's literacy rates in the early modern period are less visible to us than men's. ${ }^{45}$ Concrete estimates of women's literacy, based on such evidence as wills and library inventories, vary significantly. Pedro Cátedra and Anastasio Rojo estimate in their study of wills and library inventories in sixteenth-century Valladolid that some 24 percent of women in the lower-middle to upper classes in that city could read, judged by their ability to sign their names..$^{46}$ Ángel Weruaga-Prieto's study on documents from Salamanca yields numbers similar to Cátedra and Rojo's, but Nieves Baranda, in her work on educational institutions for women, cites studies with lower estimates. ${ }^{47}$ Baranda highlights the significance of Serafín de Tapia's study of St. Teresa's home city of Ávila, in which only 6.7 percent of women who made wills could sign their names in 1510 , a rate that increased only to 24.5 percent by 1628 . In Madrid, Baranda observes, literacy rates appear to have climbed a bit higher, achieving, according to Claude Larquié's study, some 35 percent by $1650 .{ }^{48}$ Though scholars disagree on precise literacy rates, it remains clear that sixteenth-century women faced significant barriers to access to literary culture. Even carefully conducted analyses of civic records, moreover, cannot produce reliable estimates for literacy as we have come to understand it in the twenty-first century. As Cruz and Lisa Vollendorf point out, in early modern Spain,

Cruz, 'Reading over Men's Shoulders', 42.

6 Cátedra and Rojo Vega, Bibliotecas y lecturas de mujeres, 42.

47 Weruaga Prieto, 'La lectura femenina en la Salamanca moderna', 145.

48 Baranda Leturio, 'L'éducation des femmes dans l'Espagne post-tridentine', 30. 
reading was often taught independently of writing. ${ }^{49} \mathrm{~A}$ woman who could sign her name might have been able to read or write little else, and a woman might have been a fluent reader without knowing how to write. Yet in the aggregate, the studies suggest that female literacy, while not widespread except in the most aristocratic families, was an emerging and significant phenomenon in the Spanish Golden Age..$^{0}$

Furthermore, the available evidence points to chivalric romance as one of the genres that most appealed to women. According to Marín Pina, chivalry was a particular draw for this audience because it projected a gratifying image of the literate woman..$^{11}$ José María Paz Gago points out that books of chivalry were documented in many women's library inventories. ${ }^{52}$ Isabel la Católica's library, for example, contained several romances, most of them translations from the French. ${ }^{53}$ Chivalric romances, as Nieves Baranda points out, were also well represented among books dedicated to women. ${ }^{54}$ While Baranda cautions that dedications are only approximate testimonies of reading, she finds that the idealized images of women in the dedications 'educate' the reading public about women's literacy. 55

Some women in Spain responded to the chivalric genre by recreating it, perhaps thereby imitating the literate women represented within the narratives and in the dedications. In the Spanish court, the French princess Isabel de Valois, wife of Felipe II, and her ladies staged masques and games inspired by Iberian romance, despite the fact that her husband was not fond of chivalry..$^{6}$ St. Teresa of Ávila read, acted out, and even wrote chivalric romance alongside her brother; in reading chivalry, moreover, the siblings appear to have followed the example of their mother. ${ }^{57}$ Valladolid resident Beatriz Bernal, a notary's widow and avid

49 Cruz, 'Introduction', 1; Vollendorf, 'Cervantes and His Women Readers', 314.

50 Cruz, 'Introduction', 1; Baranda Leturio, 'Léducation des femmes dans l'Espagne posttridentine', 30 .

51 Marín Pina, 'La mujer', 133; Marín Pina, Páginas, 196.

52 Paz Gago, 'La noble lectora', 176.

53 Chevalier lists Isabel's books of chivalry as the Merlin, La demanda del Santo Grial, La historia de Lançarote, and El libro del caballero Cifar. Chevalier also notes that library inventories are only an approximation of a reader's taste, and that those who read books of chivalry might not have had them in their possession when the inventory was taken. See Lectura y lectores, $75,73$. 54 Baranda Leturio, 'Women's Reading Habits: Book Dedications to Female Patrons in Early Modern Spain', 25.

55 Ibid., 26.

56 Paz Gago notes that Isabel de Valois and her ladies imitated Amadis de Gaula, Florisel de Niquea, and El caballero del Febo. 'La noble lectora', 182.

57 Bernárdez-Robal, 'Las mujeres lectoras en el Quijote', 289; Marín Pina, 'La mujer', 129; Chevalier, Lectura y lectores, 75 . 
book collector who rented rooms to boarders, wrote a full-length romance of chivalry, Cristalián de España, in which she reworked motifs from Tirant lo Blanch, Amadís, La crónica troyana, and Las sergas de Esplandián. ${ }^{8}$ The anonymous chivalric romance Palmerín de Oliva has on occasion been attributed to a female author, as the Latin verses appended to its conclusion describe the writer as a docta puella ('learned girl'). ${ }^{59}$ Even this small sample makes clear that it was possible for women of early modern Spain to read chivalry and to create their own versions of romance, and that access to the texts extended at the very least from the aristocracy to the urban bourgeoisie.

This is not to suggest, however, that women's literacy and access to chivalric texts were givens in early modern Castile. The vogues for Amadís span a period of dramatic change in publishing, literacy rates for men and women, and literary taste. Amadís de Gaula emerged in print in the 149os, during Isabel's reign and the first flowering of print culture in Spain. It remained a widely known cultural artifact in Spain at least through the early seventeenth century. By the time of Lope de Vega's La dama boba in 1613, roughly contemporary with Don Quixote, an illiterate woman of the upper class could be played for laughs, but the same could not be said of the time period that produced Amadis, either the c. 1350 primitive romance or Montalvo's version from the $1490 \mathrm{~s}^{60}$ In medieval romance, literacy is not guaranteed even for queens and princesses, and characters who send or read letters often use scribes and monks to help them. Reading and writing, especially in private contexts, mark modernizing trends within the pages of a sixteenth-century romance. Between Montalvo and Lope-and between Oriana and Cervantes's Dorotea-lies the print revolution and the democratization of literary culture it made possible. And yet, as the studies cited by Baranda and Cruz illustrate, many women of the early seventeenth century had not achieved what twenty-first-century scholars would consider full literacy. The stubbornly illiterate Finea of La dama boba is perhaps not as deviant from the norm as Lope's play makes her seem, and the changes inaugurated by the print era had not yet taken full effect for women during the time period when Cervantes imitated Amadís. Chivalry may be a minor player in the cultural shift toward full literacy for women, but it was an early innovator in imagining women doing things with the written word. 


\section{Women as Inscribed Readers}

Authors and printers alike in the early modern era seem to have been aware that women were part of their audience, and they courted female readers through book dedications, illustrations, and in-text representations of women's literacy. The woodcuts accompanying early editions of Amadis indicate that women are among the imaginary consumers of the romances. Many of the illustrations heading chapters of Amadis feature ancillary female characters on the side or foreground of the image, observing the main characters and even reacting to them with gestures such as hands clasped over the heart. Some of these observer characters, moreover, have books in their hands, gendering the act of reading as feminine. The men of the woodblock illustrations, meanwhile, engage in active pursuits like hunting, fighting, or traveling by boat. These illustrations would have guided consumers of the texts - even, potentially, illiterate ones - toward understanding women both as a literate class and as appreciators of romance. As Francisco de Monzón wrote in his 1560 treatise El norte de idiotas (The Compass of Idiots), early modern woodcuts were thought to provide alternate visual texts that could be 'read' via their symbolism: 'Muchos provechos se siguen, generalmente de la vista y adoracion de las imagenes, y principalmente a las personas simples y sin letras, que segun se dize, son sus libros (Many advantages generally come from the viewing and adoration of images, principally to simple, illiterate people, for whom they are their books)' ${ }^{61}$ Though Monzón wrote specifically about devotional images, his notion of the purpose of illustration could be applied to the Amadís woodcuts, which represent recognizable versions of well-known episodes. The presence within them of female observer-readers suggests that the phenomenon of female readership of romance was likewise well known.

Within the actual text of the romances, the episodes in which women read and write could be taken as a similar metafictional consideration of the audience. The romance of chivalry is not the only early modern Spanish literary genre to depict women, but it is among the most inclusive. Medical and conduct texts of the period treat women as an afterthought, while chronicles feature exceptional women like Isabel la Católica rather than ordinary women. The romance of chivalry, moreover, makes participation in the narrative a relatively low-stakes activity for its female characters. It stages some scenes within the domestic sphere and does not require women, either as characters or readers, to step entirely outside their expected gender 
Figure 1 Woodcut of Amadís fainting after entering Arcaláus's dungeons, surrounded by ladies, one of whom is reading a book. From the 1519 Rome edition published by Antonio de Salamanca.

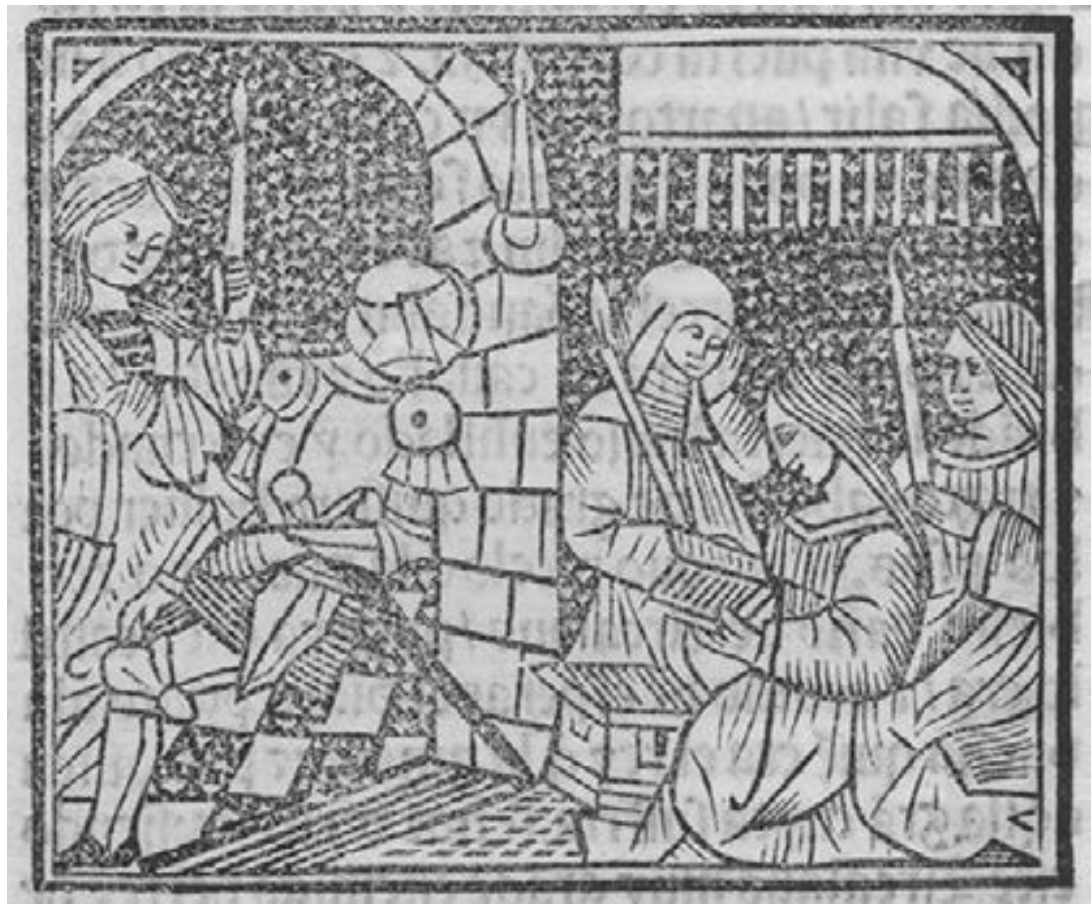

roles. Indeed, the transgressions of chivalry are insidious, balanced against moments of conformity. As Teresa de Lauretis has argued, representations of gender archetypes, like the writing women featured in certain chivalric romances, have a twofold relationship with the formation of gender ideology. For de Lauretis, 'the construction of gender is both the product and the process of its representation, ${ }^{62}$ Though, as de Lauretis cautions, these relationships are not simple, representations document a society's current view of gender and suggest revisions to received ideas about gender. She argues that the concept of gender is itself, at its core, a representation: 'Gender is not sex, a state of nature, but the representation of each individual in terms of a particular social relation which pre-exists the individual and is predicated on the conceptual and rigid (structural) opposition of two biological sexes'.63

62 De Lauretis, Technologies of Gender, 5 .

63 Ibid. 
Figure 2 Woodcut accompanying the chapter with Amadís's erotic liaison with Oriana. Amadís leads Oriana by the hand while her maid looks on, modeling the affective response the scene should elicit from its readers. From the 1533 Venice edition published by Juan Antonio de Sabia.

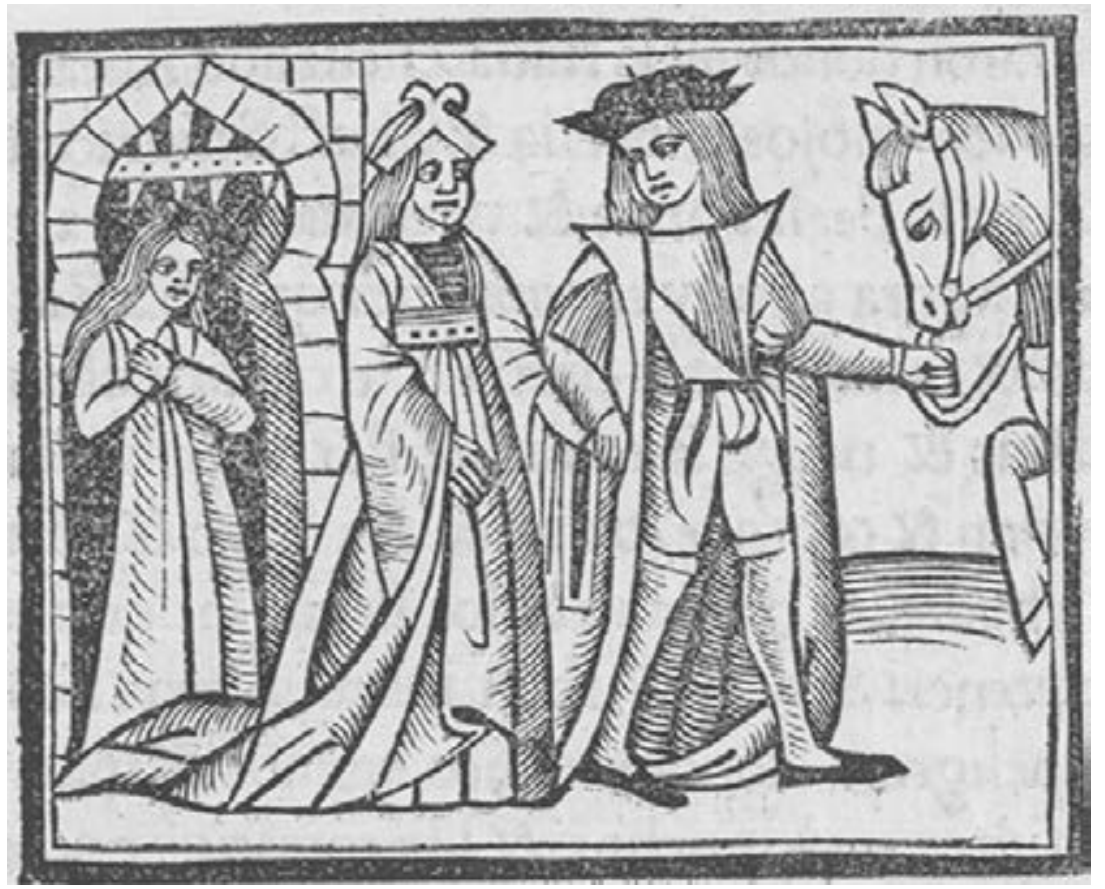

In agreement with de Lauretis, I would argue that some chivalric representations of literate women do merely inscribe gender norms as they existed in early modern Iberia. Others, however, including the depictions of women treated in this book, also make potential contributions to new practices, if at times ambivalent ones. Characters like Oriana make small steps toward independence through literary gestures that real readers could potentially imitate. As such, chivalric women contrast with the women of the exemplary tradition, including Amazons, Biblical heroines, and saints, who are represented favorably but who exist in a context very different from that of their readers. As Pamela Benson points out, texts like Boccaccio's De Mulieribus Claris (The Famous Women, 1374), Álvaro de Luna's Libro de las claras e virtuosas mugeres (Book of Famous and Virtuous Women, 1446) and even Christine de Pizan's La cité des dames (The City of Ladies, 1405) are paradoxical in their praise of women; they only offer examples that would be inconvenient or impossible for their female readership to 
follow. ${ }^{6}$ Though defenses of women do introduce new ideas about female virtue, they also support old ideas of feminine inferiority through their very structure, as, in Benson's words, 'the need of praise suggests weakness' ${ }^{65}$ Chivalric narratives, in contrast, are more parsimonious in their praise of women, but they also integrate women seamlessly into the public and private spheres of the textual world. Reading and writing, despite their subversive potential, are everyday activities for women in these texts, just as gendered and nearly as common as embroidery.

The meta-discourse of female literacy in Amadis and the texts that imitated it offer a tool for reconstructing the relationships between early modern women readers and the texts they consumed. Roger Chartier writes that reading 'rarely leaves traces', and this study recognizes the difficulty of accessing real reading practices from the early modern period. ${ }^{66}$ Marian Rothstein observes that metafictional moments can offer insight into historical reading practices when data is otherwise difficult to source, and much of the thinking about readers and readership in twentieth-century scholarship has depended on clues left by authors about the audiences they imagined for their work. ${ }^{67}$ Martyn Lyons, writing of the difficulty of finding testimonies of readership, affirms the need to search for traces of reading 'in the text itself'. ${ }^{68}$ This book, which is very much centered on textual detail, adapts models of readership from narratology and reception studies in two ways. First, I observe how the authors treated in this study seek to shape their own audiences through representations of reading and writing. Second, I trace these authors' own reading habits - their concrete testimonies of reading — through intertextual references.

Reception studies in the twentieth century offered literary scholars several terms with which to build models for the relationship between texts and their consumers. Of these, the 'ideal reader' — denoting a reader who is the product of authorial wishes - has perhaps the widest diffusion. Yet the 'ideal' reader has always presented difficulties: Louise Rosenblatt wrote in 1938 that there were no 'generic' readers, and Wayne Booth argued in 1961 that the ideal reader 'could never possibly exist'. ${ }^{69}$ Martyn Lyons, writing in 2010, agrees with Rosenblatt and Booth, observing that 'readers are not passive or docile; they make texts their own, improvising personal

64 Benson, Invention of the Renaissance Woman, 2.

65 Ibid., 15 .

66 Chartier, The Order of Books, 2.

67 Rothstein, Reading in the Renaissance, 95-96.

68 Lyons, A History of Reading and Writing, 9.

69 Rosenblatt, Literature as Exploration, 24; Booth, The Rhetoric of Fiction, 140. 
meanings and making unexpected textual connections.$^{\prime}{ }^{7}$ Even if a reader of the exact background and mindset the author had in mind should consume a text, he or she might perceive the work in a way the author did not intend. Elizabeth Freund characterizes the reader as 'the text's natural companion', but it does not follow that this companion must be responsible or skilled in the business of interpretation..$^{71}$ Lyons emphasizes how literary consumers 'select, interpret, re-work, and re-imagine what they read'. $7^{2}$ Michel de Certeau describes readers as 'travellers' and 'nomads poaching their way across fields they did not write'. ${ }^{73}$ Reading, like writing, is an exercise in chaos.

However, that does not mean that reading has no rules, or that the forces that govern it are not sometimes deliberately created. Lyons observes that readers absorb habits from the cultures, communities, and markets in which they read, forming expectations about literary texts 'through shared social experience. ${ }^{74}$ Literary works themselves are important sites for creating and reinforcing this experience, and Wolfgang Iser uses the term 'implied reader', a revision of the 'ideal reader', to describe the hypothetical reader whose action is 'pre-structured' by the text. ${ }^{75}$ For Iser, the author seeks to inculcate certain values in the 'implied reader', and, inevitably, influences real readers. Seymour Chatman emphasizes the gulf between the hypothetical implied reader and the inscrutable real reader, but Paul Ricœur calls the implied reader a correlate of the real reader, as real readers have a tendency to follow the author's 'instructions'. ${ }^{6}$ In the formulations by Iser, Chatman, and Ricœur, the implied reader is singular and abstract. It must be said, however, that some implied readers, like dedicatees, are quite real, and that authors sometimes address their texts to many different readers, skilled and unskilled, friendly and hostile, from a variety of backgrounds. I would suggest that the fundamental problem of the 'implied reader' is one shared with the 'ideal reader'; the term does not address the diversity of readers-both in demographics and in ideology — who may approach a work, both in its author's time and centuries later.

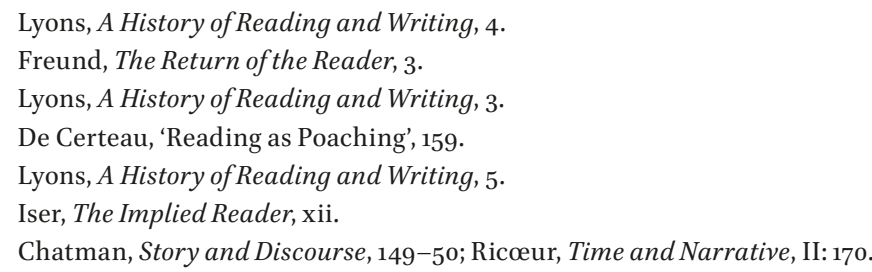


For me, the most helpful term reader-response theory uses to describe potential relationships between literary works and their audiences is the 'inscribed reader', which denotes any reader depicted within or projected by a text. Susan Suleiman points out that the key distinction between the implied reader and the inscribed reader is that while, especially in Iser's formulation, the implied reader is 'called upon to "agree" with the values of the implied author', the inscribed reader is an independent 'meaningproducing' element. ${ }^{77}$ Romances of chivalry, as well as works in other literary genres, can point to a variety of inscribed readers. Marian Rothstein describes the French Amadís as a text that directly spoke to and sought to influence its inscribed readers in authorial asides, instructing them in their literary habits..$^{7}$ I would add that this feature is not exclusive to the French translation, as it was present in the Montalvo. For me, the romances speak to readers in a second way by mirroring the action of reading through depictions of literacy and citations of other texts. I understand the fictionalized literate women of chivalric romance as inscribed readers both of the texts they interact with on the page (letters, books of magic) and of chivalric fiction itself. These fictionalized readers are not ideal in any sense, and they often deliberately misread or use their readings for sinful purposes. The concept of the inscribed reader thus makes room for the ambivalence with which chivalry represents its women.

Reading exists on many levels in the texts I study, and to describe their relative positioning, I adapt Gérard Genette's layered model of narratology, with the diegesis or narrative as the primary element and all other features positioned in relation to it as intradiegetic elements (inside the narrative) or extradiegetic elements (outside the narrative). ${ }^{79}$ The texts under examination in this study contain intradiegetic readers and writers of books, poems, and letters. Sometimes the content of interpolated texts is specified, and sometimes it is not. Characters, moreover, may make reference in their letters or dialogue to extradiegetic authors or texts, rendering these characters, in their turn, inscribed readers of those extradiegetic texts. For example, when Montalvo's Oriana adapts diction from Heroides or Cervantes's Luscinda tucks her letter inside a copy of Amadis de Gaula, the characters become inscribed readers of Ovid and Montalvo. The chain of references connecting intradiegetic and extradiegetic worlds creates a web of reading that perhaps even attempts to connect with real readers. 
Early modern thinkers believed that reading stirred the passions and caused readers to imitate the texts they enjoyed, and those beliefs, in some measure, likely conditioned the responses of real readers to chivalric romance. $^{80}$

Negative responses to chivalry from the early modern period decried the genre's ability to produce feelings and behaviors, and perhaps ironically, they are among the most enduring traces of the reception of chivalry. One of the primary assumptions the didactic tradition made about women readers of chivalry was that they sought out the genre as a means of erotic instruction. Conduct books shared a common obsession with chastity, and reading was among the dozens of quotidian habits that could threaten it. ${ }^{81}$ Moralists considered the imitation of entertainment-oriented literature to be an unconscious process that inevitably caused harm to young or female readers. ${ }^{82}$ Amadis was particularly threatening because, in Spiller's words, the work 'was understood, by both its proponents and detractors, to have powerful effects on its readers'. ${ }^{83}$ Part of the reason the text might have been perceived that way is that its intradiegetic readers, like the distraught Amadís with Oriana's letter in his hand, were themselves highly susceptible to the written word.

Humanist Juan Luis Vives's description of the dangers of chivalry in Education of a Christian Woman (1524) is the most famous condemnation of the genre, and it emphasizes the affective power chivalry could wield. ${ }^{84}$ Vives's list of books to avoid includes Amadis, other chivalric works, and two works of fiction in other genres, La Celestina (1499) and La cárcel de amor (The Prison of Love, 1492). ${ }^{85} \mathrm{He}$ criticizes these texts for their lack of erudition and verisimilitude, but his main qualm is their ability to create such emotional responses as delight, fascination, and arousal:

I wonder what it is that delights us in these books unless it be that we are attracted by indecency. [...] What madness it is to be drawn and fascinated by these tales! There is nothing clever here except for some words taken from the secret archives of Venus that are spoken at the propitious moment to impress and arouse the woman you love if she shows some resistance. ${ }^{86}$

Gagliardi, Urdiendo ficciones, 36; Spiller, 'Cervantes', 296.

81 Jehenson, 'Masochisma', 39.

82 Whitenack, 'Emphasis Added', 25.

83 Spiller, Reading, 113 .

84 Spiller, 'Cervantes', 296.

85 I cite here books mentioned in the original Latin text. The list of works varied in translation.

86 Vives, Education of a Christian Woman, 76. 
The diction of emotion Vives uses will be important to this study, as the interpolated texts attributed to women within the romances are likewise rich in feeling. For Vives, the texts seem almost to seduce readers, especially female readers: 'If a woman is so enthralled by the reading of these books that she will not put them down, they should not only be wrested from her hands, but if she shows unwillingness to peruse better books, her parents or friends should see to it that she read no books at all'. ${ }^{87}$ Vives urges parents to force disobedient daughters to 'unlearn' the ability to read; in the early sixteenth century, illiteracy still seemed a possible remedy. Yet the popularity of Celestina, Amadis, and other morally questionable works of fiction in sixteenth-century Spain suggests that readers, including women, did not wish to break the habit.

While Vives is the most severe of the conduct writers on the question, other early modern Spanish intellectuals also decried chivalric reading. Fray Luis de León suggests in La perfecta casada (The Perfect Wife, 1583) that sewing might be a salutary alternative to reading, and Menéndez y Pelayo cites a 1555 petition presented to the Cortes de Valladolid asking that the printing of chivalric books be forbidden on account of the damage Amadis and its imitators have done to young men and women. ${ }^{88}$ Donatella Gagliardi credits Beatriz Bernal, the author of a chivalric romance; Margaret Tyler, an English translator of Iberian chivalry; and other women who made contributions to the chivalric genre with 'prudent daring', a delicate balance between subversion and conformity. ${ }^{89}$ Of Bernal, Judith Whitenack writes: 'It is [...] ironic that a woman chivalric author should emerge at the very time of so many attacks on the genre by clerics and moralists convinced of the harmful effect of chivalric romances on readers, especially young, impressionable women'..$^{\circ}$ Bernal was no doubt aware of the didactic tradition, as conduct books were inventoried in her daughter's library, but she does not appear to have been discouraged by it.

The concept of literacy and authorship that emerges from Bernal and the other women readers in this book, real and fictional, encompasses both refusal to adhere to cultural norms and capitulation to them. Montserrat Piera and Jodi Shearn write that Iberian chivalric romances habitually contain 'heroines who, in spite of the restrictions imposed on them, textually perform, and thus exhibit to the reader, the ambiguity and problematic

87 Ibid., 78 .

88 Fray Luis de León, La Perfecta Casada, 80; Menéndez y Pelayo, Orígenes de la novela, 1:269.

89 Gagliardi, Urdiendo ficciones, 106.

90 Whitenack, 'Emphasis Added', 25. 
nature of the female speaking subject'. ${ }^{11}$ This book treats many women who reflect what Piera and Shearn term a 'resistant double-voiced discourse'. ${ }^{92}$ Yet some of the female archetypes that oppose male-dominated hierarchies in the early modern era appear here only in passing. The specter of Queen Isabel, as Barbara Weissberger has persuasively argued, haunts Iberian cultural discourse at the turn of the sixteenth century, but she is not the preoccupation of this work. ${ }^{93}$ Amazon-like warrior women, so memorable in the texts of Montalvo and others, make only a few appearances in these pages. I focus my attention on the female characters who read and write from within the domestic sphere and thus participate in a shadow version of the real literary market.

\section{Intertextuality and Reading}

Thus far I have primarily discussed reading in terms of the instructions texts leave for readers. This book also looks at reading through the citation and imitation of other texts, considering the networks of intertextuality in which early modern writers participate to be traces of the experiences of readers. Like the construction of the inscribed reader, these references signify in multiple ways and bridge intradiegetic and extradiegetic worlds. Though each of the chapters in this book focuses on a single author, the boundaries between the phenomena I discuss are porous, and pieces of the story I tell about the chivalric genre overlap and comingle. For Michel Foucault, 'the frontiers of a book are never clear-cut: beyond the title, the first lines, and the last full stop, beyond its internal configuration and its autonomous form, it is caught up in a system of references to other books, other texts, other sentences: it is a node within a network'. ${ }^{44}$ Foucault's description is particularly apt for chivalric romance, with its tendency toward serialization, unattributed citation, and pastiche.

In the early modern period, chivalric texts incorporate material from their sources in a variety of ways, many of which are difficult for twentyfirst-century readers to unravel. They continue a tradition of an earlier period, citing medieval texts piecemeal, and authors often obscure their own role in the creation of a text through such tropes as the apocryphal 
found manuscript. Translations, working with real 'found' manuscripts, tend to obscure the origin and authorship of source works, even when they are known to the translator. Multiple authors tell the same story, as is the case with the sequels to Amadis in Spain. Adaptations of an earlier work can be respectful, parodic, or both. Chivalric writers interpolate not just chivalric romance, but also texts in other genres that blend well with the motifs of chivalry. Even though chivalric romance is not usually thought to express the values of the Renaissance, it does demonstrate the complex interweaving of citation and original material that typifies the humanist approach to citation..$^{95}$

To describe the complex relationships between the texts I study and their sources, I make use of the term intertextuality, coined by Julia Kristeva in response to Mikhail Bakhtin's concept of heteroglossia, which he used to describe the intermixing of different kinds of utterances in verbal or written speech..$^{96}$ For Kristeva, 'any text is constructed as a mosaic of quotations; any text is the absorption and transformation of another. The notion of intertextuality replaces that of intersubjectivity, and poetic language is read as at least double. ${ }^{97}$ Kristeva argues that citation and imitation undermine the subjectivity of the author, which indeed they do, if one understands the author as the genius who exercises absolute control over all dimensions of a literary work. Roland Barthes replaces this unifying 'Author' with the term 'scriptor', which limits the control attributed to authors and allows for the flow of influence from sources outside the author's consciousness..$^{8}$ Barthes's scriptor possesses an 'immense dictionary' of material on which to draw, much of it absorbed through reading. The scriptor produces texts 'made of multiple writings, drawn from many cultures and entering into mutual relations of dialogue, parody, contestation'. ${ }^{99}$ Barthes's famous declaration of the death of the 'Author' allowed the reader to be the person around whom the meanings of a literary text coalesce. ${ }^{100}$ I agree with Barthes about the powers of the reader, but in this project, I emphasize the ways in which authors are also readers and thus enjoy a reader's capabilities. Judith Still and Michael Worton observe that 'imitation must [...] be seen as a theory not only of writing but also of reading as a performative act of

95 Quint, Origin and Originality, 5-7.

96 Bakhtin, The Dialogic Imagination, 263.

97 Kristeva, The Kristeva Reader, 37. Original emphasis.

98 Barthes, Image, Music, Text, 145.

99 Ibid., 148.

100 Ibid. 
criticism and interpretation'. ${ }^{101}$ As Daniel Gutiérrez Trápaga has argued, moreover, chivalric works in early modern Iberia engage in a high degree of intertextuality, perpetuating themselves through 'rewriting, continuation, and cycles'. ${ }^{102}$ The authors I study in this book adapt material from chivalric romance for their own purposes, exaggerating or diminishing aspects of the source material to suit new narrative situations.

Each work I mention in this book has in common a reading of Amadis, but the approach varies. Bernal expresses consistent enthusiasm for the tropes she adapts from the famous romance, while Cervantes exhibits greater critical distance. In Montero, the reading of Amadís is indirect, showing up in one clear citation and in a second-level reading via Don Quixote. Yet I do not confine my study of intertextuality to references to Amadis. Still and Worton argue that intertextuality enters the reading process in two ways. First, in the most familiar use of the term, authors incorporate multiple 'references, quotations, and influences' in their own literary works. ${ }^{103}$ There is a secondary dimension of intertextuality, however, that arises on the reader's end, when a reader brings his or her set of intertextual references to bear on the interpretation of a text. ${ }^{104}$ The authors studied here brought other sources into their reading of Amadis, and it is evident that they blended references to Amadis with other kinds of citations. Ovid and Iberian sentimental novels are mutual sources for Montalvo, Bernal, and Cervantes, and all these authors were likewise familiar with some version of the exemplary and conduct tradition. Rosa Montero, meanwhile, probably read Amadis through Cervantes, which would have tinged her chivalric borrowings with irony and nostalgia. This book points out moments where citations weave together to emphasize the complexity of reading as a contributor to the authorial process.

\section{Writing, Agency, and Emotion}

Though the association between women and literacy in the texts I study is fairly clear, the question of whether writing women, real and fictionalized, can be said to have agency is a matter of debate. For the purposes of this study, I define agency narrowly, as the capacity to act, decide, or choose,

101 Still and Worton, 'Introduction', 7.

102 Gutiérrez Trápaga, Rewritings, Sequels, and Cycles, 11.

103 Still and Worton, 'Introduction', 1.

104 Ibid., 2. 
whether or not that action is free of exterior constraint. Writing accompanies many of these choices. Cruz describes writing as a 'vital rhetorical and social tool' for early modern Spanish women. ${ }^{105}$ James Daybell and Andrew Gordon, writing in the English context, discuss the letters of early modern women as 'tools[s] for investigating the exercise of agency across a number of spheres'. Daybell and Gordon find that women used letters 'as an instrument in public life' and employed 'sophisticated strategies' in doing so. ${ }^{106}$ As Daybell and Gordon caution, historical women letter writers had to negotiate their ancillary social roles as submissive wives and daughters in order to use letters in this way. Indeed, women's texts, real and fictionalized, often play to stereotype, echoing or even supporting dominant notions of gendered behavior.

Michel Foucault famously argued that power and its discourses bring subjects into being, and in this study, women's texts engage, directly or indirectly, with the contradictory ideals of femininity circulating in Golden Age culture. For Foucault, power 'categorizes the individual, marks him by his own individuality, attaches him to his own identity, imposes a law of truth on him which he must recognize and which others have to recognize in him'. ${ }^{107}$ Judith Butler elaborates on Foucault's model of subject formation, arguing that 'power that first appears as external, pressed upon the subject, pressing the subject into subordination, assumes a psychic form that constitutes the subject's self-identity'. ${ }^{108}$ If agency exists, it depends, paradoxically, on the discourses it seeks to resist. In the case of the real and fictionalized early modern women who are the subject of my study, discourses of gender shape the words and tropes they use to combat the pressures these notions bring to bear.

One might logically question whether the female characters or authors of chivalric fiction have any capacity for agency at all. Pierre Bourdieu writes in Distinction that what might appear to be free choices are always bounded by habitus, which he defines as 'the internalised form of class condition and of the conditioning it entails'. ${ }^{109}$ For Bourdieu, the aggregate effects of socialization become 'embodied' cognitive structures that seem almost natural. Agency, then, cannot be understood as free of influence. However, as Butler observes, the fact that agency cannot exist except in response to

105 Cruz, 'Introduction', 2.

106 Daybell and Gordon, 'Living Letters', 21-22.

107 Foucault, 'The Subject and Power', 781.

108 Butler, The Psychic Life of Power, 3.

109 Bourdieu, Distinction, 101. 
discourses of power does not mean that resistance is impossible or that transgressions are not worthy of examination. ${ }^{110}$ Each instance of what I term women's agency in this book corresponds to a choice, usually between action and inaction. Though women express their perspectives in response to gender roles, literary tropes, and class-based expectations, they also defy these discourses, if in equivocal ways.

Even in those cases, however, where women's writing seems to reinforce gender norms, the fact that the writing exists or is represented fictionally constitutes a form of resistance. For Golden Age women, real and fictional, writing - especially writing a letter-was always a risk. Instances of women's literacy in chivalric romance and the imitations it inspired are more than mere convenience or passive reflections of a growing literacy rate; letters and books are among the least secure ways to transmit information, as any literate person may read them. Sending a messenger or keeping silent, indeed, would have seemed the safer or more expedient option in many of the instances I discuss. These fictionalized examples of women's writing, moreover, are doubly compromised, as many are examples of what Thomas Beebee terms 'male ventriloquism', or male-authored utterances attributed to women. ${ }^{111}$ This study, however, finds these representations of women's literacy significant for two reasons: they reveal the limits of permissible behavior for women in early modern Spain, and they suggest a link between writing and emotion that points forward to the future of the novel.

Writing and reading tend to feature in chivalric episodes that involve sentimental and family ties. Personal letters announce pregnancies and births, reveal love and hate, and maintain relationships across distance. Books of magic, meanwhile, contain prophecies that connect characters across time and distance, giving them a way to have knowledge of loved ones, or even of the future, without direct contact. Writing tends to be a deeply private act for chivalric characters, especially women, and the interpolated letters allow glimpses of individual psychology to emerge in a genre that usually exteriorizes sentiment through displays of weeping, shouting, or fainting. Women's texts in chivalric romance, which tend to be rich in the diction of the body and to reference these externalizations of feeling, bridge the Galenic notion of emotion as the imbalance of bodily 
humors and more modern conceptions of emotion as the 'inward, intimate' expression of the mind. ${ }^{112}$

Emotion has an intimate relationship with agency, and, as Jan Plamper points out, a conflict remains both for scientists and for historians of emotion as to whether emotions are automatic or cognitive, innate or learned. ${ }^{113}$ Though it is beyond the scope of this study to offer an opinion on how feelings arise, it does seem clear that cultural factors influenced how emotions could be represented in literary texts. Discourses of gender and class impact the diction of emotion, and intertextuality informs how characters are said to think and feel. I find particularly interesting for this study the moments that combine women's writing, emotions, and agency; this is the case with Oriana's letter, the texts that imitate it, and many of the other instances of women's writing under discussion in this book.

\section{Chivalry, Reading, and Women's Culture}

The organization of Chivalry, Reading, and Women's Culture in Early Modern Spain is chronological, allowing the reader to track the reception over time of the female characters of Amadís. Chapter One discusses episodes in Montalvo's 1508 Amadís de Gaula associated with a network of female characters: Amadís's mother, Elisena; his lover, Oriana; her own mother, Brisena; and the enchantress Urganda la Desconocida. Amadís recounts the histories of two generations of women through two pregnancies, two childbirths, and many letter exchanges. This chapter pays particular attention to the embedded epistles written by female characters. I show how the letters of Amadis align themselves with existing models for correspondence, including the medieval ars dictaminis, Ovid's Heroides, and the sentimental novel. Female correspondents fuse the affective, embodied discourse of Heroides with the decorum-oriented structure of ars dictaminis. In Amadís, women's letters are a proxy for action, tracing a parallel plotline in which women contest male dominance of the romance world.

In Chapter Two, I turn to Beatriz Bernal's Cristalián de España (1545), a chivalric romance whose main business is reading. Bernal's text is rich in allusions to other works of Iberian chivalry, including Amadís de Gaula, Tirant lo Blanch, Las sergas de Esplandián, and La crónica troyana. Though

112 Plamper, The History of Emotions, 28-33.

113 Ibid., 5 . 
Bernal cites motifs and character archetypes from Amadís de Gaula, her work is not a direct sequel to Montalvo's romance. Bernal is nonetheless a more perceptive reader of gender in Amadís than her counterparts Feliciano de Silva, Ruy Páez de Ribera, Juan Díaz, and Pedro de Luján, who wrote continuations of the 1508 text. Bernal adapts motifs associated with women's learning, letters, and books from Montalvo's romances and uses them to ponder whether women can gain authority or agency through literary practices. While Bernal remains sympathetic toward her large cast of female characters, many incur social punishment as a consequence of their attempts to exercise agency through the written word. To the female reader of chivalry, Bernal offers hope, but also caution.

Miguel de Cervantes, like Bernal a reader of Amadís and other works of Iberian chivalry, also capitalizes on the literate potential of chivalric women. In Chapter Three, I show that in Don Quixote Part I, Cervantes appropriated Amadis's representation of literate women to explore how and why early modern women consumed literature. Among the readers and listeners of chivalry in Part I of Don Quixote, Cervantes includes several women: Maritornes, the innkeeper's daughter, Dorotea, and Luscinda. Luscinda and Dorotea are expert readers of chivalric romance who imitate the literate women of Amadis to find solutions for gender-related difficulties. In this chapter, I compare and contrast the reading practices of male and female inscribed readers, showing how Cervantes destabilizes the gender polarities established by other works. The letter exchange between Luscinda and Cardenio in Don Quixote Part I is a multifaceted imitation of Amadís de Gaula, Diego de San Pedro's Arnalte y Lucenda and La cárcel de amor, and Ovid's Heroides and Metamorphoses. Dorotea's life narrative and performance as the princess Micomicona, meanwhile, oppose the strictures of the conduct tradition to the ludic tropes of chivalric romance. Lucinda and Dorotea engage in tacit cooperation through their shared reading material, and their partnership ultimately saves both from ruin. In Don Quixote Part I, the practice of literacy enables women's triumphs in a context hostile to their needs and perspectives.

Chapter Four offers a counterpoint to Chapter Three by analyzing a more sinister group of female readers of chivalry in Don Quixote, the duchess and her handmaidens in Part II. A reading community comprised of women coalesces around the duchess, and the servants and their mistress engage in collective imitations of chivalry that entrap and victimize Don Quixote and Sancho. This reading community exists at a level of remove from Amadís de Gaula. The women imitate Don Quixote's imitations of Amadis from Part I, degrading the idealism of the quixotic 
impulse. Cervantes illustrates through these women the chaos of the early modern literary market, pairing the rebellious servant girl Altisidora with the work of apocryphal sequel writer Alonso Fernández de Avellaneda in a vision of hell. Though the death of Altisidora represents the defeat of literate women, her swift resurrection signals women's continued participation in literary culture at the turn of the seventeenth century. In Part II, Cervantes intimates that Amadís and texts like it are flawed reading material, especially for women. However, rather than denying women access to literature, Cervantes guides readers like Altisidora to a set of authors that, for him, represent high culture: Virgil, Dante, Ariosto, and Garcilaso.

In the conclusion to the book, I move the story of imitation and adaptation of Iberian romance forward to the twenty-first century, showing that chivalric motifs oriented to literate women continue to have cultural currency in modern Spanish letters. Rosa Montero's 2005 novel La historia del rey transparente (The Story of the Transparent King) overtly cites Don Quixote and Arthurian legend in a novel about the coming of age of a girl knight, and it interpolates Amadis directly at one moment and indirectly at many others. Literacy is one of Montero's primary themes, and of the works treated in this book, her novel most clearly links writing, agency, and the emotions. Leola, a female version of an unknown knight like Lancelot or Amadís, builds a scholarly career alongside a military one, collapsing the figures of the warrior and the sabia into one. Though there is no explicit vogue for Amadis in twenty-first-century popular literature, Montero's quixotic, neo-Arthurian, neomedieval novel shows that Iberian chivalry continues to speak to literary audiences interested in the evolution of gender politics. Though Montero does not evoke Amadís by name, she engages with it at a distance, assuring Amadis one more afterlife in the modern novel. 


\section{Women's Lives and Women's Literacy in Amadís de Gaula}

Amadis de Gaula (1508) appealed to sixteenth-century Castilian readers, including women, because it re-interpreted the Arthurian world in ways uniquely suited to early modern Spain. Amadís has always been marked by cross-cultural borrowings and influences. The work tells the story of Amadís, a prince of Gaul, and Oriana, the daughter-heir to the throne of Britain, who work together to overcome obstacles to their marriage and unite their kingdoms under a joint rule. The legend first arose in Castile around $135^{\circ}$ in response to French Arthurian romances, especially the prose Lancelot. ${ }^{1}$ Garci Rodríguez de Montalvo, a fifteenth-century nobleman from Medina del Campo, combined one or more medieval or 'primitive' versions of the legend with new material. ${ }^{2}$ The work utilizes diction and narratological structures that recall medieval romances and chronicles, but its concept of the self, the state, and the roles of men and women points toward the modern. ${ }^{3}$ Daniel Eisenberg characterizes Amadís as 'a link between the medieval and the Renaissance periods', and indeed, Montalvo's Amadis contains courtly language typical of the late fifteenth century and encomia to the Catholic Kings. ${ }^{4}$

A crucial but underappreciated aspect of Amadís de Gaula's forwardlooking gaze is its representation of women's culture, by which I mean women's stories, women's spaces, and women's texts. Amadís de Gaula contains thirty-eight named female characters, compared to just over two hundred male characters. ${ }^{5}$ While the text offers many episodes in which men accomplish daring feats, it also introduces queens, princesses, mothers, wives, sisters, aunts, and serving women who interact with each other and with men. Amadis organizes itself through the device of interlace, with

1 For the connection between Amadis and Arthurian legend, see Alvar, 'Materia de Bretaña', 21; Harney, 'Spanish Lancelot', 185; Gil-Albarellos, Amadís de Gaula y el género caballeresco en España, 32; Riquer, Estudios sobre el Amadís de Gaula, 13.

2 See Lida de Malkiel, 'Arthurian Literature', 414-15; Sharrer, 'The Acclimatization of the Lancelot-Grail Cycle in Spain and Portugal', 186; Entwistle, The Arthurian Legend, 217; Avalle-Arce, El Amadís primitivo y el de Montalvo, 119; Pierce, Amadís de Gaula, 55.

3 Mancing, The Chivalric World of Don Quijote, 22; Tarzibachi, 'Sobre el autor', 29.

4 Eisenberg, Romances of Chivalry, 31; Pierce, Amadís de Gaula, 21; Cacho Blecua, 'Introducción a los gestos', 56-68; Lucía Megías, 'Los cuatro libros', 94.

5 I base my count on Cacho Blecua's index in his edition of Rodríguez de Montalvo's Amadis de Gaula, II: 1769-1807. 
strands of narrative focalized on different characters alternating throughout the 1508 text's four volumes. ${ }^{6}$ Chapters tend to begin with men and with combat, but once the battle ends, men return to households of women. Female characters have two axes of influence in Amadis, one concerned with reproduction and the other concerned with literacy. Amadis de Gaula thus fuses a traditional notion of women's identity and social role, motherhood, with an emerging conception of women's power to act on the world through reading and writing. This chapter focuses on acts of writing by women that express a degree of agency, here defined as the expression of a decision or choice, whether or not that choice is bounded by gender expectations. Amadis is remarkable for the way it recounts the histories of two generations of women through two pregnancies, two childbirths, and many letter exchanges. Amadis's depiction of women's literacy, not coincidentally, arises at a historical moment when more women were gaining access to the written word as readers of books, participants in literary circles, and writers of letters.

By highlighting the role of women's culture in Amadis, I do not mean to suggest that the romance is not about men or men's culture. Indeed, many scholars have noted and even lamented how masculine Amadis and its genre can be. Judith Whitenack refers to the romance of chivalry as a 'traditionally male genre', and Simone Pinet characterizes the typical plot as a series of encounters between men and their environment. ${ }^{7}$ For José Julio Martín Romero, chivalric romance is particularly adapted for male readers looking to climb the social ladder. ${ }^{8}$ In a similar vein, Jesús Rodríguez Velasco identifies in the romance of chivalry the 'chivalric fable', a habitual narrative pattern in which a knight—almost always a man—rises from obscurity due to his devoted service to the monarch. ${ }^{9}$ In addition, Iberian romance contains many female characters who appear less dynamic than their male counterparts. ${ }^{10}$ Indeed, for Montserrat Piera, the representation of women as passive and men as active in most Iberian romances of chivalry reflects the genre's patriarchal vision of medieval and early modern social relationships. ${ }^{11}$ Nevertheless, there are female characters in Amadis who

10 Eisenberg, for example, writes that in Iberian romance, 'both literally and figuratively, women are the spectators at the tournament'. Romances of Chivalry, 71.

11 Piera, 'Minerva', 74. 
have names, responsibilities, agendas, strengths, and weaknesses. Through them, Montalvo's text also recounts fables for women.

Though the women of Amadis are at times harder to see than the men, they are central to the text's development of individual and collective psychology. It is the women of Amadís who desire, observe, think, feel, and write, and as such, they are the primary bodies through which affect circulates. For the purposes of this chapter, I use the terms affect, feeling, and emotion as Ben Anderson and Brian Massumi define them. For Anderson, affect is the movement of the 'more than rational or the less than rational' among bodies, while 'feelings' are the words (blushes, smiles, tears) used to describe the physical effects of this process. Emotions, meanwhile, are 'those intimate, distinctly personal, ways of being that are retrospectively named.' ${ }^{12}$ Clarifying the difference between emotion and affect, Massumi writes that 'emotion is a subjective content, the socio-linguistic fixing of the quality of an experience'; emotion is the 'intensity' of affect defined and explained. ${ }^{13}$ Particularly when women characters are present, Amadis dramatizes the movement of affect, its manifestation in the body through feeling, and its expression as emotion in written or spoken language. Moreover, when characters in Amadis interact with each other or with text, phenomena Gregg and Seigworth refer to as 'contagions of feeling' tend to arise. ${ }^{14}$ In Amadis, affect is an axis of encounter, as important as that of adventure, which allows men and women to connect or compete. Just as adventure has its material vehicles—swords, horses, and magical objects—chivalric affect has a preferred medium: the letter. Amadis is indeed a tale of adventure, but it is also an early epistolary fiction. In this chapter, I suggest a reading of Amadís based on its letters, offering an alternate, woman-oriented journey through Amadis's narrative of a family and a nation.

\section{A Romance for Two Eras}

The letters of Amadis and the affective plotline they enable date to Montalvo's fifteenth-century revisions of the medieval legend. By changing the tragic ending and allowing the romance's two protagonists to live happily

\footnotetext{
12 Anderson, 'Becoming and Being Hopeful', 735-37. Jan Plamper, in contrast to Anderson, uses emotion and feeling interchangeably, and indeed, the two are intimately tied. See Plamper, The History of Emotions, 12.

13 Plamper, The History of Emotions, 15.

14 Gregg and Seigworth, The Affect Theory Reader, 8.
} 
ever after, Montalvo participates in a moral and cultural shift that began with the primitive Amadis. Harney and Williamson observe that in Iberian romance, conflicts among parents and children replace the Arthurian adultery plots. ${ }^{15}$ The medieval Amadís and Oriana did not commit adultery, but they did defy parental directives in order to be together. In imitation of Arthurian legend, the primitive Amadís ended in disaster: Amadís and his son, Esplandián, engaged in ritual combat without recognizing each other; Esplandián killed his father; and Oriana threw herself from a window in her grief. ${ }^{16}$ In Montalvo's version, by contrast, Amadís and Oriana marry and succeed jointly to the thrones of Gaul and Britain, while a legitimized Esplandián moves east to conquer pagan territory near Constantinople. ${ }^{17}$

It is possible to view the sentimental plots of Montalvo's Amadis as traditional in their notion of gender, as the stories drive women toward marriage, reproduction, and apparent social conformity. While the medieval Amadís and Oriana were modeled after Lancelot and Guinevere and Tristan and Isolde, their early modern counterparts in many ways leave courtly love behind. Michael Harney observes that in the early modern text, Amadís and Oriana's 'future-aligned, household-oriented devotion' has led many readers to dismiss the romance as 'bourgeois'. ${ }^{18}$ For me, what is important about the happy ending of the 1508 Amadis is that it refuses to punish Oriana for her infractions against chastity. The early modern Amadis allows the Castilian counterpart of Guinevere and Isolde to marry, produce a male heir, and become part of her society's future. By contrast, Peggy McCracken notes that adulterous queens in medieval French romance rarely have children; these texts cannot contemplate an illegitimate child rising to the throne. ${ }^{19}$ In Amadís, two princesses-Amadís's mother, Elisena, and his future wife, Oriana-conceive children in the context of clandestine marriages of dubious legality. Marian Rothstein argues that these pregnancies, far from being a mark of shame, render the characters exemplary: 'In a world in which women are valued for their capacity to produce children, their secret marriages allow the novels' heroines to furnish readers with an immediate assurance of the female equivalent of valor [...] by producing male heirs' ${ }^{20}$ Amadís forgives its female sinners and depicts mothers, children,

17 Esplandián's rise to the throne of the Eastern Roman empire occurs in Montalvo's original sequel, Las sergas de Esplandián, of which the first extant edition dates to $15^{05}$.

18 Harney, Kinship, 145-46; Harney, 'Spanish Lancelot', 190.

19 McCracken, Romance of Adultery, 28.

20

Rothstein, 'Clandestine Marriage', 886. 
and childhood at intervals throughout the romance. The 1508 text offers detailed accounts of the conception and birth of Amadís and Esplandián and narrates scattered moments from the early childhood of Amadís; Amadís's brother Galaor; Amadís's sister, Melicia; Oriana; and Esplandián. Mothers participate in most of these scenes.

However, women's culture in Amadis is not entirely expressed in the context of the nuclear family, as the female protagonist of the work is Britain's future ruler. Throughout the text, Montalvo implies a comparison between Oriana and the historical Isabel..$^{21}$ Frank Pierce notes that Montalvo had ample access to the royal mythology and court culture of the Catholic Kings, as his home city of Medina del Campo was among Isabel's favored royal residences. ${ }^{22}$ María Luzdivina Cuesta Torre finds the debate over Oriana's inheritance to be a reference to the life of Isabel, while Lucila Lobato Osorio identifies in Oriana certain Isabeline qualities. ${ }^{23}$ The coincidences in the biographies of Oriana and Isabel serve to ennoble Oriana, whose moral status is otherwise difficult to determine. Indeed, scholars disagree on what Oriana is supposed to represent for readers. Juan Bautista Avalle-Arce and Frank Pierce emphasize her jealousy, while Eisenberg points out that Montalvo criticizes the character in authorial intrusions. ${ }^{24}$ However, Justina Ruiz de Conde notes Oriana's redeeming qualities, remarking on her 'great sense of responsibility' and 'extraordinary judgment'. ${ }^{25}$ María Aguilar Perdomo considers Oriana's rejection of Amadís unjustified, while José Manuel Lucía Megías blames Amadís's bumbling dwarf for feeding her misinformation. ${ }^{26}$ For me, this critical disagreement reflects the textual contradictions that result from the rewriting of the medieval Amadis. Despite these ambiguities, the fact that a literate Oriana survives to rule Britain in the early modern Amadis de Gaula enacts a progressive gender politics, whether or not the editor-compiler Montalvo meant to do so.

Women's culture in Amadís de Gaula expresses itself most poignantly in the symmetry between the lives of Elisena and Oriana, Amadís's mother and wife, respectively. Though unrelated by blood, these two women play similar roles within their family and political networks. Both suffer secret pregnancies and are forced to abandon their first-born sons. They marry

Triplette, 'From Guinevere to Isabel'.

Pierce, Amadís de Gaula, 14.

Cuesta Torre, 'Realidad histórica', 106; Lobato Osorio, 'El auxilio a Oriana', 130.

Avalle-Arce, El Amadís primitivo y el de Montalvo, 172; Pierce, Amadís de Gaula, 62; Eisenberg,

Ruiz de Conde, El amor y el matrimonio secreto, 191.

Aguilar Perdomo, 'La penitencia de amor caballeresca', 191; Lucía Megías, 'Los cuatro libros', 98. 
their lovers and recover their lost children after long years of suffering. Letters - written by women, not men — play key roles in the articulation of their relationships, bringing about both family rupture and family reconciliation. What is so striking about the gender politics of Amadis is its emphasis on thought and feeling in stories about women. In contrast, medical treatises and conduct literature tend to talk about women as pathologies, objects, or beings so subordinate that they lack cognitive or affective capacity. Indeed, before we can properly appreciate the singular depiction of women's lives in Amadis, it will be helpful to consider more conventional treatments of women's bodily experience.

\section{Medieval and Early Modern Pregnancy}

Amadís de Gaula shares with medieval and early modern medical and conduct literature the persistent association of women and reproduction. Most medieval medical treatises adhere to the humoral theories of Hippocrates, Aristotle, and Galen, which attribute disease to imbalances in a delicate system composed of four bodily humors. ${ }^{27}$ Katherine Gatto writes that according to these theories, 'men were viewed as complete unto themselves while women needed men to complete them. ${ }^{28}$ Women, cold and wet by nature, were thought to seek the salutary heat and dryness of men. ${ }^{29}$ While both men and women were said to have seed or semen that participated in the reproductive process, men's was the strongest and most necessary. Although such texts dedicated only a small portion of their pages to women's medical troubles, they did recognize reproductive disorders and the dangers of birth, ascribing both to women's essential inferiority $3^{30}$ Medieval medicine viewed women as particularly 'rooted in the body', as opposed to men, who were credited with a more intellectual mode of being. ${ }^{31}$

While physical symptoms are more prominent than emotions or personality in such works, medical treatises refer to sufferers of mental and emotional illnesses such as melancholy or lovesickness with masculine pronouns. It is possible that the male pronouns used in the medical discussion of emotion and personality are meant to stand for both genders, an idea which 
would seem to be supported by the theories upheld by sixteenth-century physician Juan Calvo and others that consider women's genitalia to be the inverse of men's and viewed the bodily fluids of milk, semen, and blood as interchangeable. ${ }^{32}$ Yet Francisco López de Villalobos, court physician to Fernando el Católico, treats men and women as entirely separate creatures and depicts the latter as susceptible to pride and jealousy. ${ }^{33}$ When the medical tradition offers specific discussion of events that occur only in women, such as childbirth, it tends to make recommendations for behavior rather than suggest treatments for symtoms. Only rarely are women's emotions represented at all. Indeed, Petrus Hispanus's thirteenth-century Thesaurus Pauperum (Treasure of the Poor) is a rare exception, as it names sadness among the symptoms that indicate problems in the womb. ${ }^{34}$

One of the most detailed medieval treatises on women's health is the twelfth-century Sicilian Trotula, a compendium of three texts named for an apocryphal female physician. ${ }^{35}$ The first treatise in the set, The Condition of Women, takes its inspiration from Greek physician Galen by way of Ibn al-Jazzar's Viaticum. ${ }^{36}$ Based on humoral theory, this treatise urges women in labor to avoid cold and suggests unguents and scents as remedies. ${ }^{37}$ The treatise frames the danger of childbirth in a misogynist reading of the human condition: 'Because women are by nature weaker than men and because they are most frequently afflicted in childbirth, diseases very often abound in them especially around the organs devoted to the work of Nature' $3^{8}$ The second treatise, Treatments for Women, is a collection of folk wisdom and herbal remedies. It suggests practical techniques for midwives, including instructions for stitching perineal tears, but it pays no attention to emotion.

Another influential medieval medical text, Aldobrandino of Siena's thirteenth-century Le régime du corps (The Order of the Body), gives detailed advice for preventing miscarriages and prescribes specific diets for pregnant women. ${ }^{39}$ The Aldobrandino text contains more specific information about childbirth than the Trotula, including a description of the position of the

Calvo, Cirugía universal, 9-10.

López de Villalobos, Medical Works of Francisco López de Villalobos, xviii.r.

Petrus Hispanus, The Treasury of Health, 88.

35 More than one hundred manuscripts of the Trotula survive, and the text's diffusion extended throughout Europe, including the Iberian Peninsula. See Green, 'Introduction', 51; Arriaga, Desde Andalucía, 74 .

36 Green, 'Introduction', 25.

37 Green, ed., The Trotula: A Medieval Compendium of Women's Medicine, 105.

38 Ibid., 71 .

39 Ward, Women in Medieval Europe, 55. 
infant during normal labor. ${ }^{40}$ The author follows with discussion of stillbirths and breech births, ending with the recommendation that postpartum women bathe, treat themselves to good food, and take medicines if they have pain..$^{41}$ While the Aldobrandino treatise does attend, at least briefly, to the physical experience of childbirth, the only remark about emotion occurs in the recommendation that pregnant women avoid troublesome thoughts in order to prevent miscarriage. ${ }^{42}$

In the Castilian context, the Alfonsine Lapidario (Lapidary) combined the humoral theory of medicine with lore about the salutary benefits of stones. The Lapidario, translated from Arabic in 1250, resembles Treatments for Women in that it prescribes remedies for specific illnesses, usually in the form of stones ground and mixed in potions or worn on the body. For women, the Lapidario suggests several stones that facilitate labor, facilitate or prevent conception, and treat gynecological disease. ${ }^{43}$ While some stones in the Lapidario are said to have psychological or emotional effects, such as preventing fear, none address women's emotions, and only one addresses women's physical pain. The only emotion the Lapidario references in connection with women is sexual desire. ${ }^{44}$ The Lapidario, like the Trotula and the Aldobrandino treatise, recognizes the dangers of childbirth and pregnancy for mother and fetus alike but does not describe the emotional dimension of those experiences.

Sixteenth-century Castilian conduct books often reiterated traditional medical advice on maternity. Pedro de Luján dedicates more space in his Coloquios matrimoniales (Colloquies on Matrimony, 1550) to pregnancy than to any other feminine life experience. The Coloquios are a series of Erasmian dialogues, which is perhaps surprising considering that Luján also wrote a sequel to Amadís de Gaula titled Silves de la Selva (1546). Erasmians were famously hostile to all forms of fiction, especially the romance of chivalry. In the Coloquios, Luján presents conversations between a learned married woman, Doroctea, and her young friend Eulalia, a reluctant bride. In the fourth colloquy, Doroctea presents seven reasons why women miscarry. Six are women's fault: wearing tight clothing, eating fruit, drinking too much wine, attending dinner parties, hearing news, and leaving the house for any reason. ${ }^{45}$ Men, however, are responsible for some miscarriages, as

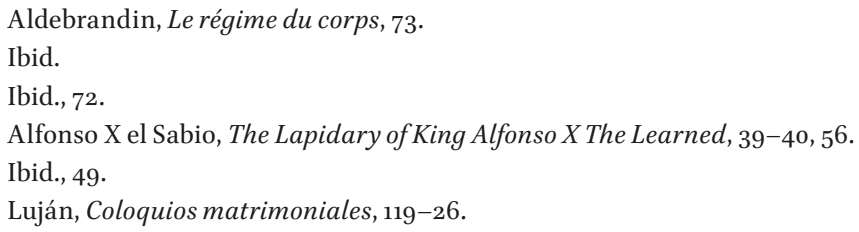


they have a tendency to provoke their wives to anger. ${ }^{46}$ Doroctea's advice is quite similar to Aldobrandino's, though Luján develops it with exempla from antiquity. While Luján's attention to pregnancy might seem a window into women's culture, in fact his recommendations for pregnant womenmodesty, moderation, and isolation-echo conventional restrictions on women's behavior.

Luján's discussion of pregnancy is heavily indebted to Antonio de Guevara's 1529 Relox de príncipes (The Dial of Princes), which provides the classical anecdotes and the seven reasons for miscarriage. ${ }^{47}$ The major difference between Luján and Guevara is that the female personae in Luján give the illusion that the author values women's perspectives. Readers might perceive that Doroctea, who has children of her own, might be drawing on her own experience as well as her extensive learning. Ironically, Guevara, the real source of Doroctea's knowledge, dismisses women's ability to understand pregnancy and childbirth. He declares that he, a male priest, knows more about the subject than any woman could, as wise men who read about a phenomenon comprehend it better than simple people who have only experienced it. ${ }^{4}$ Guevara's criticism of women's ignorance is ironic, as he and other conduct writers supported limitations on women's education. Guevara also compares pregnant women to bears, wolves, lionesses, hazelnut trees, and chestnut trees, implying that women, especially pregnant women, are something less than human. ${ }^{49}$

In literature, if not in medical discourse, the women of early modern Spain have the capacity to feel emotion. For example, George Yuri Porras writes that Melibea of La Celestina, a roughly contemporary figure with the female characters of Amadis, suffers a textbook case of lovesickness. ${ }^{50}$ Amadis shares the conduct books' focus on women's sexual identities, but like La Celestina, it credits women with the same affective capacities as men. Michael Harney has remarked the importance in Iberian chivalry of 'the closely related issues of sexuality, family structure, genealogy, property, sibling rivalry, and bastardy'. ${ }^{1}$ Amadis de Gaula, however, does more than merely include stories focused on sex, pregnancy, and childbirth; it imbeds these embodied, feminine experiences in an affective

46 Ibid., 129 .

47 See Asunción Rallo Gruss's notes to Luján's fourth colloquy for a detailed comparison to Relox de príncipes. The pertinent sections of Guevara are Relox II:X-XII.

48 Guevara, Relox, I:X:LXXX.r.

49 Ibid., II:XI:LXXXII.v.

50 Porras, 'El mal de amores', 143.

51 Harney, Kinship, 18. 
framework and juxtaposes them with acts of writing. In contrast to the conduct tradition, Amadis emphasizes women as thinking and feeling beings who encode their perspective in written letters. While men also write letters in Amadis, they are far less likely to use them to express emotion.

\section{Epistolary Chivalry}

The 1508 Amadis de Gaula mentions thirty-three letters, of which fourteen are quoted in the text. Female characters predominate among the letter writers: Darioleta (the maid of Amadís's mother, Elisena); Oriana; Oriana's mother, Brisena; the princess Celinda; and the enchantress Urganda contribute quoted letters. Three men write quoted letters: Amadís (multiple letters), minor character Angriote de Estraváus, and minor character Arbán de Norgales (one letter, written jointly). The unquoted letters are primarily cartas de creencia, diplomatic equivalents to letters of introduction, or carteles de batalla, letters of challenge..$^{2}$ Male correspondents, with the exception of Amadís himself, send letters only for political purposes. The women of Amadis use letters to maintain family ties.

The letters of Amadis form a quasi-physical link between the body of the writer and the body of the reader. In her theory of epistolary fiction, Janet Altman characterizes the letter as a 'metonymy of the self' that bridges the distance between characters. ${ }^{53}$ Recipients interact with letters physically, holding, kissing, or talking to the paper. Letter writers depict their own suffering with references to parts of the body, and recipients feel visceral effects when they read. Teresa Brennan writes that certain environments favor the transmission of affect from one body to another. ${ }^{54}$ The letters of Amadis create one such situation: feelings are contagious, and letters are their host medium. Writing about the sentimental novel La cárcel de amor (The Prison of Love), whose conditions for affective transfer are similar to Amadis, Emily Francomano argues that letters 'are more than linguistic objects meant to be read, interpreted, and provoke action; they are physical extensions of their writers, talismanic objects, and the material currency of the romance's poetic economy'. ${ }^{55}$ In both chivalric and sentimental romance, 
the material specificity of the letters impacts their meaning. The texts frequently mention ink, paper, envelopes, seals, greetings, and postscripts. For Altman, the level of 'epistolarity' in a text, which she defines as 'the use of the letter's formal properties to create meaning', reveals the degree to which the text meditates on the communicative process..$^{6}$ In Amadis, the form and materiality of the letters indicates that communication is a major thematic concern for the romance.

Thinking about the role of letters in Amadís can help us reconsider the supposed division between the romance of chivalry and the sentimental novel. Barbara Weissberger has advocated that the two forms be considered subvarieties of a single genre called 'romance' on account of their thematic parallels, and I would add that the true connection between the two genres is the interpolated letters through which they inscribe women's perspectives. ${ }^{57}$ Elizabeth Spiller and María Carmen Marín Pina have noticed the epistolary features of Amadis, and Marina Brownlee and Keith Whinnom have observed other similarities that link the two genres..$^{8}$ Moreover, though chivalric and sentimental romances are quite different in length and print format, the sixteenth-century literary market appears to have perceived them as similar objects. Feliciano de Silva, who wrote several sequels to Montalvo's Amadis, places Juan Rodríguez del Padrón, author of the sentimental novel Siervo libre de amor (The Servant Now Free of Love), in the catalog of loyal lovers in Amadís de Grecia. ${ }^{99}$ Juan Luis Vives criticizes Amadis de Gaula and La cárcel de amor in the same paragraph, writing that women should avoid 'pernicious books like those popular in Spain: Amadís, Esplandián, Florisando, Tirant, Tristán [...] Celestina, the brothel-keeper, begetter of wickedness, the Prison of Love ${ }^{60}$ Perhaps readers familiar with both genres realized that they covered similar emotional ground; indeed, if one looks only at the letters of Amadis, it begins to read very much like a sentimental novel. It is worth noting, moreover, that both genres included women among their inscribed readers. Both genres depicted their female characters reading and writing, and many works in both genres are dedicated to women. Moreover, as Patricia Grieve notes, Diego de San Pedro's Arnalte y Lucenda was dedicated to all the women of the Isabeline court, which indicates

56 Altman, Epistolarity, 4.

57 Weissberger, 'The Gendered Taxonomy of Spanish Romance', 211, 216.

58 Spiller, 'Cervantes', 202-203; Marín Pina, Páginas, 172; Brownlee, Severed Word, 148, 163; Whinnom, 'Introducción', 52.

59 Silva, Choronica del muy valiente y esforçado principe y cauallero de la ardiente espada Amadis de Grecia, $94 \mathrm{v}$.

6o Vives, Education of a Christian Woman, 75 . 
that the sentimental novel could imagine not just individual, exceptional women as its audience, but women as a larger class. ${ }^{61}$

In recent decades, critics have accorded the sentimental novel a place in the history of epistolary fiction. Marina Brownlee describes the Spanish sentimental novel as 'consistently—and significantly—epistolary'. ${ }^{62}$ Thomas Beebee does not consider all Spanish sentimental romances to be epistolary novels in the modern sense, but he credits Juan de Segura's Proceso de cartas (The Process of Letters) as the landmark work in the genre. ${ }^{63}$ If the sentimental novel can be considered an early epistolary novel, by the same critieria, Amadis, which interpolates letters and their material qualities in the same way, must also be considered a precursor to the epistolary fictions of the seventeenth and eighteenth centuries. Amadis de Gaula may perhaps have had an even greater impact on the epistolary novel in France than its sentimental counterparts, many of which were translated into French in the sixteenth century, but none of which reached as many readers as the French Amadis. ${ }^{6}$

The presence of epistolarity in Amadís, moreover, has intriguing implications for gender in the text. The missives of Amadis are examples of what Beebee terms 'male ventriloquism', and while they reveal how Montalvo conceptualized women's experience, they cannot shed light on how real Castilian women of Montalvo's era thought, read, or spoke. ${ }^{65}$ Juan Bautista Avalle-Arce argues that Montalvo most likely wrote all or most of the letters, as they reflect the style and diction of the late fifteenth century. ${ }^{66}$ Moreover, Montalvo's Las sergas de Esplandián (The Deeds of Esplandián), an original work, contains even more letters than Amadís de Gaula. Montalvo's letters are studied constructions, and their dense networks of citation reveal that Montalvo considered women's words important enough to merit literary allusion and strategic composition. The medieval ars dictaminis ('art of composition') allows the female letter writers of Amadís to exploit social hierarchy, while allusions to Ovid's Heroides inform their expression of emotion. Moreover, by attributing literary allusion to female writers, Montalvo

61 Grieve, 'Mothers and Daughters in Fifteenth-Century Spanish Sentimental Romance: Implications for Celestina', 346.

62 Brownlee, Severed Word, 70.

63 Beebee, Epistolary Fiction, 50.

64 La cárcel de amor, Arnalte y Lucenda, Grisel y Mirabella (as Aurello et Isabelle) and other sentimental novels were translated into French in the sixteenth century. Nicolas de Herberay, the translator of the French Amadis de Gaule, also translated Arnalte y Lucenda.

65 Beebee, Epistolary Fiction, 106.

66 Avalle-Arce, El Amadís primitivo y el de Montalvo, 197. 
renders women a vehicle for intertextuality and thus inscribed readers of the works they cite. Male characters, in contrast, read and write less frequently, and it is the women who model the actions of the extradiegetic reader by interacting with text.

The interpolated letters of Amadis, though favorable to women in many ways, reflect the ambivalence with which the romance views its female characters more generally. Though the letters occasionally provoke misogynist commentary from the characters or from Montalvo via authorial intrusion, Montalvo allows these missives to reconcile long-lost family members, negotiate peace between nations, and predict the future. Whether or not Montalvo realized it, by crafting letters in the voices of women like Oriana and the enchantress Urganda, he communicates to the reading public that literacy provides women with the means to influence the patriarchal structures of the family and the state.

\section{Writing the Family Origin}

The story of women's letters in Amadís begins in the first chapters of Book I, with a baby tucked in a wooden ark alongside a sword, a ring, and a scrap of waxed parchment. The letter, which reads 'Este es Amadís sin Tiempo, hijo de rey (This is Amadís Without Time, the son of a king)', accompanies the infant as he floats, Moses-like, down the river and into the sea. ${ }^{67}$ Amadís's origin story draws on familiar tropes of myth and legend. ${ }^{68}$ Like Lancelot, Amadís begins his journey as a knight before he learns of his parentage, but what happens to the families afterward is quite different. Lancelot's parents do not reenter their child's life story, but thanks to the cryptic letter, Amadís reunites with his mother and father and assumes his place as heir to the throne of Gaul.

Amadís de Gaula pays a great deal of attention to Amadís's mother, Elisena. In a genre in which male children are often described as copies of their fathers, Amadís appears to inherit his most distinct qualities-his sensitivity, his fidelity, and his need for solitude-from his mother. Perión is a brash, competent, and gregarious young knight who engages in at least one dalliance with a woman before he meets Elisena. Amadís will become as brave as his father, but he remains shy and devoted to Oriana throughout his life. The opening pages of Amadís likewise orient themselves to women;

67 Rodríguez de Montalvo, Amadís de Gaula, I: 246.

68 Cacho Blecua, Amadís: heroísmo mítico cortesano, 16. 
the first paragraph introduces not King Perión of Gaul but King Garínter, the grandfather of Amadís, and his two daughters, Amadís's mother and aunt. The elder, known as the Lady of the Garland, is already married to the King of Scotland; Amadís will join her household in early adolescence. The second daughter, Elisena, is lovelier than her sister, a woman of 'retraimiento y santa vida (reserve and saintly habits)'. ${ }^{69}$ She has refused many offers of marriage, causing Garínter's courtiers to refer to her as a 'beata perdida', an excessively religious old maid. The young princess's lack of interest in men dissipates when she is seated next to Perión in her father's hall. After dinner, Elisena places her ring in her lap so that she can wash her hands. Distracted by her handsome dining companion, she stands up without replacing it. The ring clatters to the floor, both young people bend to pick it up, and the rest is history.

Perión and Elisena's famous liaison, which follows that very night, includes a promise of future marriage. Michael Harney remarks that such promises 'exculpated carnal madness' in Iberian romances of chivalry. ${ }^{70}$ Scholars have debated whether this episode meets the conditions for a legal clandestine marriage in pre-Council of Trent Europe. Medieval Castilian law held the specific consent to marriage of both parties plus sexual intercourse to constitute a legal marriage..$^{71}$ Harney points out that while families tended to emphasize the rights of kin groups, the medieval church prioritized individual consent..$^{72}$ In this case, it is clear that Elisena consents to sex, but not specifically to marriage. Perión, however, swears upon his sword (to Darioleta the maid) that he will marry Elisena eventually, which suffices for his consent. Perión later gives Elisena his ring, which Justina Ruiz de Conde takes as confirmation of the marriage. ${ }^{73}$ I would caution that rings are exchanged and vows sworn for many purposes in chivalric romance. In my opinion, Perión and Elisena's marriage exists in a legal gray area until it is celebrated publicly, many chapters later. The text, however, does seem to grant Amadís retroactive legitimacy.74

69 Rodríguez de Montalvo, Amadís de Gaula, I: 227.

70 Harney, Kinship, 242.

71 Hindson, 'Fernando-Dorotea', 483.

72 Harney, Kinship, 107-108.

73 Ruiz de Conde, El amor y el matrimonio secreto, 174.

74 The matter of Amadís's inheritance provides some of the best evidence that Montalvo's text considers him legitimate. Perión and Elisena have a younger son, Galaor, whose legitimacy is never in doubt, but he never contests his brother's primogeniture. Perión also has an older son, Florestán, product of an earlier liaison, who likewise does not attempt to inherit his father's kingdom. Amadís assumes the throne of Gaul in Las sergas de Esplandián, at a time when both his brothers are alive and well, indicating that Montalvo almost certainly saw him 
Yet the legality of Perión and Elisena's clandestine marriage, however controversial, is not the focus of the episode. Instead, the text emphasizes the two characters' subjective experience, which it renders with a rich vocabulary of feeling.

Transformations of the body, physical and metaphoric, mark the emotional upheavals in these chapters. Upon brushing hands with Perión, Elisena blushes, and as she follows her mother from the hall she is nearly blind with love: 'Cuasi la vista perdida llevava (She had almost lost her sight)' ${ }^{7}$ The text describes Elisena's 'piadosas lágrimas (piteous tears)' and the 'fuerça que en su coraçon avía sentido (shock which she had felt in her heart)'. Perión, for his part, tells Darioleta that he is 'llagado de herida mortal (stricken by a mortal wound) $\cdot{ }^{76}$ Perión then experiences a symbolic nightmare in which a hand reaches into his chest, pulls out his heart, and throws it in the river. ${ }^{77}$ He later learns from his court magician that the hand represents Elisena and the heart their abandoned son..$^{78}$ In the opening sequence of Amadís, Perión is not the seducer but the seduced, and two women-Elisena and her maid - determine his amatory destiny. His emotions are important, but hers determine the course of their future. Perión's dream marks out this striking reversal of gender politics, establishing Amadis as a story about women's role in the foundation of families.

The next chapter of Amadís narrates Elisena's pregnancy in terms attentive to her physical and emotional state. When Perión leaves for Gaul, Elisena feels deep sadness: 'Quedó con mucha soledad y con grande dolor de su amigo (She was left in much loneliness and great pain due to the absence of her lover)' ${ }^{79}$ The physical symptoms of Elisena's pregnancy mirror her troubled emotional state: 'Preñada se sentió, perdiendo el comer, el dormir y la muy hermosa color (She knew herself to be pregnant, as she had lost her appetite, her ability to sleep, and the lovely color in her face), ${ }^{80}$ These phrases describe the symptoms of morning sickness, and they also match the sadness, pale color, and listlessness that, according to Petrus Hispanus's

as legitimate. Justina Ruiz de Conde argues that Amadís was always legitimate, but Edwin Williamson calls him 'an illegitimate baby'. See Ruiz de Conde, El amor y el matrimonio secreto, 204; Williamson, The Half-Way House of Fiction, 40.

75 Rodríguez de Montalvo, Amadís de Gaula, I: 231.

76 Rodríguez de Montalvo, Amadís de Gaula, I: 232.

77 Ibid., I: 238.

78 Ibid., I: 251.

79 Ibid., I: 242.

80 Ibid. 
Thesaurus Pauperum, indicated problems in the womb. ${ }^{81}$ They also bear close resemblance to the symptoms for lovesickness.

Emotions, especially fear, threaten to overcome Elisena: 'Allí fueron las cuitas y los dolores en mayor grado, y no sin causa, porque en aquella sazón era por ley estableçido que cualquiera muger por de estado grande y señorío que fuesse, si en adulterio se fallava, no podía en ninguna guisa excusar la muerte (Then she felt grief and pain to a greater degree, and not without cause, because at that time it was established by law that any woman, no matter how great her status, who was found in adultery could not be excused from death) ${ }^{82}$ Importantly, the text does not say that Elisena deserves punishment. ${ }^{83}$ The 'ley de Escocia (law of Scotland)' that condemns women is referred to as a 'cruel costumbre (cruel custom)' ${ }^{84}$ It is the law itself, not the mother who seeks to circumvent it, that the text describes as 'cruel'. Elisena could be seen by some readers as a cruel mother, as Darioleta's plan of placing the baby in the basket would likely lead to his death. Yet Elisena herself objects on account of the emotional connection she feels with the child's father: ‘Cómo consentiré yo matar aquello que fue engendrado por la cosa del mundo que yo más amo? (How could I consent to killing that which was engendered by the thing in the world I love most?). ${ }^{85}$ Amadis creates a moral dilemma featuring a transgressive woman and a harsh law, and incredibly, the text resolves it in favor of the woman.

One of the best indicators that the text is sympathetic to Elisena is the continuing focus on Elisena's thoughts and feelings during her child's birth. In the final weeks of her pregnancy, Elisena's parents allow her to retreat to an isolated house by a river. The text then describes the birth of Amadís in relatively direct terms:

Le vino el tiempo de parir, de que los dolores sintiendo como cosa tan nueva, tan estraña para ella, en grande amargura su coraçon era puesto, como aquella que le convenía no poder gemir ni quexar, que su angustia

81 Petrus Hispanus, The Treasury of Health, 88.

82 Rodríguez de Montalvo, Amadís de Gaula, I: 242-43.

83 Rothstein, 'Clandestine Marriage', 875 .

84 The 'ley de Escocia' that Elisena fears is a much-commented feature of Amadís. Entwistle traces the motif to the Vulgate Merlin. See The Arthurian Legend, 217. According to Barbara Matulka, the law of Scotland did not reference a specific rule from Scotland, but its antecedent could be a pair of Scottish saints' lives, the stories of St. Kentigern and the blessed Barra. Matulka finds evidence for both banishment and burning as punishments for adultery in Spain. See Matulka, The Novels of Juan de Flores, 55-63.

85 Rodríguez de Montalvo, Amadís de Gaula, I: 244. 
con ello se doblava; mas en cabo de una pieça quiso el Señor poderoso que sin peligro suyo un fijo pariesse.

(The time of birth came upon her, and she felt the pains as a new and strange thing. Her heart was placed in great bitterness, for she did not dare cry out or complain, which redoubled her anguish. But after a while mighty God willed that without danger she should give birth to a son. $)^{86}$

This description recounts the physical experience of childbirth through the words amargura ('bitterness') and angustia ('anguish'). The secrecy with which Elisena gives birth renders her, perhaps ironically, an exemplary pregnant woman by Guevara's definition: 'Deven las mugeres en general, y las princesas y grandes señoras en particular, andar assosegadas y estar muy quietas (Women in general, and especially princesses and great ladies, should be quiet and still)'. ${ }^{87}$ Guevara here refers to behavior during pregnancy, but Elisena's ability to keep silent through the pain of childbirth is likely meant to express her propriety and fortitude.

For Amadis de Gaula, pregnancy is important enough to feature twice. The second maternity sequence, featuring Amadís's wife, Oriana, shows that women matter to this text not as exceptional figures, but as a class of people with common experiences. Oriana, like Elisena, begins to suspect that she is pregnant when she experiences a 'gran flaqueza de su persona (great weakness of her person)' and a 'gran mudança de su salud (great change in her health). ${ }^{88}$ She fears the law of Scotland as Elisena did, and, like her predecessor, retreats from company. Unlike Elisena, Oriana articulates a sensible plan for her child's survival, arranging for an abbess to find the baby a suitable nurse. ${ }^{89}$ Oriana, an update of a prior exemplar of maternity, combines emotional sensitivity with a capacity for cool-headed planning.

When Oriana goes into labor, the text attends to her physical experience: 'Según los desmayos y lo que sentía, que no era otra cosa sino que quería parir (Based on her faintess and the sensations she felt, she must have been ready to give birth).$^{90}$ The faintness is perhaps meant to indicate a medical problem; Petrus Hispanus associates faintness with painful childbirth, and Juan Calvo, writing in the late sixteenth century, associates desmayos ('fainting spells') more generally with gynecological malfunction. $\cdot{ }^{91}$ Oriana,

86 Ibid., I: $245^{-46 .}$

87 Guevara, Relox, II:LXXX.v.

88 Rodríguez de Montalvo, Amadís de Gaula, I: 920.

89 Ibid., I: 921.

90 Ibid., II: 1003.

91 Petrus Hispanus, The Treasury of Health, 91; Calvo, Cirugía universal, 167. 
however, appears to be experiencing a normal if emotionally fraught labor. The reader gets a sense of the timeline and the progression of Oriana's contractions: 'Allí estuvo Oriana con algunos dolores fasta la noche, y con ellos recibiendo algún tanto de fatiga; mas de allí adelante la afincaron mucho más en cuantidad (Oriana had some pains until nightfall, from which she felt somewhat fatigued, but from then on they increased in quantity)..$^{2}$ Though this description of labor is centered on the body, it also includes emotion, describing 'el gran miedo que tenía de ser descubierta de aquella afruenta $[. .$.$] que sin quexarse lo sufría (the great fear she had of being$ discovered [...] so that she suffered without complaint). ${ }^{93}$ Oriana's stoic silence reiterates the most salient detail of Elisena's labor, and in further connection to Elisena, the text refuses to depict Oriana as a cruel mother. After the birth, she shows affection to the infant Esplandián, taking him into her arms and kissing him. The childbirth experiences of Elisena and Oriana combine emotional and physical detail, and they both conclude with hints at the women's capacity for maternal love.

Though the behavior that led to Amadís's birth is imprudent at best, it is essential to Montalvo's dynastic fable that Elisena escape punishment. However, the abandoned infant Amadís would never have risen to the throne of Britain and Gaul if not for a second act of feminine daring, the quick thinking of Darioleta, Elisena's handmaiden. Darioleta writes a letter to accompany the baby in the basket: 'La donzella tomó tinta y pergamino, $y$ fizo una carta (The damsel took up ink and parchment and wrote a letter)'. ${ }^{94}$ Darioleta then covers the letter in wax. The end result is a document small enough to fit inside a ring and durable enough to endure the ravages of water and time. Within the short text of the letter, the name 'Amadís sin tiempo (Amadís without time)' indicates that Darioleta does not expect the child to survive. The sadness Elisena felt during her pregnancy and birth finds brief expression in the bleakness of the phrase sin tiempo, rendering women's letters, even in this small example, a vector for emotion. The descriptor 'hijo de rey (son of a king)', however, articulates a hope for the infant's future, as the person who finds the son of a king might be inclined to help him. Darioleta's letter thus also expresses, in a transmuted way, Elisena's maternal affection. All the emotions of the sexual liaison and the childbirth scene lead to the letter's composition and are, in a sense, inscribed within it. This letter proves efficient at holding and transmitting women's emotion, as it 
will later become the foundational text that enables Amadís to reconcile with his parents, marry Oriana, and rule Britain and Gaul alongside his wife.

In order to accomplish its goals, the waxed letter must travel, linking characters across time and distance. Amadís's foster parents find the bit of wax, but they do not realize it is a letter. At the prompting of the enchantress Urganda, Galvanes gives the object to his adoptive son, then known as the Donzel del Mar. Oriana asks Amadís for the apparently valueless bit of wax as a keepsake, and on a sea journey, the wax breaks and Oriana notices the words, fifteen years after Darioleta wrote them. ${ }^{95}$ Oriana here becomes the letter's inscribed reader; she is the first person to interact with it after Darioleta and thus the mirror of the extradiegetic reader. Once Oriana learns from the letter that her sworn knight is the son of a king, she indulges feelings that might otherwise have led nowhere. Oriana then sends the letter by messenger back to Amadís, who speaks to the letter as if it were a character: ‘`Ay, carta, cómo fuestes bien guardada por aquella señora cuyo es mi coraçon! (Oh letter, how well you were kept by that lady who possesses my heart!) ${ }^{9}{ }^{6}$ The waxed letter has both materiality and what Francomano terms 'corporeality' - the ability to stand in for a living body. ${ }^{97}$

Even though this particular letter contains only one sentence, it bridges the physical and social gaps between Amadís and Oriana and then reunites Amadís with his birth parents. Soon after discovering that he is the son of an unknown king, Amadís defends Gaul from evil King Abiés and then visits Perión and Elisena. This is a writing family: upon her father's death, Elisena wrote a letter to Perión informing him of her freedom, and they were publicly married soon after..$^{8}$ The reader learns that the ring Perión gave Elisena is one of a pair; when he asks her about it, she claims to have lost it. ${ }^{99}$ During Amadís's visit, Perión and Elisena's youngest child, Melicia, has been playing with her father's ring and grows upset when she cannot find it. Amadís gallantly gives the little girl a similar ring from his hand-the one with which he was found as an infant. When Perión sees this ring, he becomes enraged, as the ring Melicia thought she had lost is still on Perión's finger. The king of Gaul leaps to the conclusion that his wife gave the ring to this stranger as a love token and then lied about it. Amadís is quick to save Elisena's reputation by showing off the waxed letter, which Elisena

97 Francomano, 'Puse un sobrescripto', 27.

98 Rodríguez de Montalvo, Amadís de Gaula, I: 262.

99 Ibid., I: 325 . 
recognizes as 'la mesma que Darioleta por su mano escriviera (the very one Darioleta wrote with her hand)'. ${ }^{100}$ The letter again serves as a vector for the transfer of affect. Elisena details her changed emotional state as she welcomes Amadís to her family: 'Mi amado hijo, cuando esta carta se scrivió era yo en toda cuita y dolor, y agora soy en toda holgança y alegría (My beloved son, when this letter was written I felt nothing but grief and pain, and now I am overcome with pleasure and joy)'. ${ }^{101}$

The waxed letter illustrates the principles that drive the circulation of epistles in Amadis. The letter passes into the possession of six characters before it accomplishes its communicative goal. Chance, not intent, dictates who reads it: Galvanes and Amadís fail to notice the letter inside the wax, and Oriana reads it when she is not supposed to. A misunderstanding brings it to its final readers, Perión and Elisena, closing the circle on the group of writers and recipients. Gary Schneider, citing Harold Love's notion of scribal publication, refers to communicative circles of this type as scribal communities. ${ }^{102}$ According to Schneider, in the early modern period, personal letters circulated among many readers, with or without the writer's permission, and all letters risked being read out of context. ${ }^{103}$ The path of this particular letter traces out a family group with Amadís at its center, and the materiality of the letter is key to both its failure and its success. Its small size delays its discovery, but the wax allows it to survive adverse conditions. The waxed letter brings the past into the present, and it places the characters on the path to familial and political union.

\section{Writing the Emotions}

Although Darioleta's letter reunites the ruling family of Gaul, its impact results from chance rather than composition strategy. Oriana, a far more deliberate writer than the servant girl, uses a variety of classical and medieval allusions to assure that her interlocutors will accede to her requests. Perhaps ironically, the most important epistle in Amadis de Gaula threatens the bonds that Darioleta's letter made possible. In the beginning of Book II, Oriana hears a report of Amadís's infidelity and sends a letter severing all ties. Amadís replies by way of a ballad in which he declares that he will

100 Ibid., I: 328.

101 Ibid.

102 Schneider, Culture of Epistolarity, 23; Love, Culture and Commerce, 177.

103 Schneider, Culture of Epistolarity, 26. 
soon die of grief. Once independent evidence has convinced Oriana of Amadís's innocence, she sends him a letter of apology, and Amadís pardons her by sending a reply letter. The reconciliation of the characters leads to the conception of Esplandián, which motivates both further letters and an eventual public marriage. Like Darioleta's letter, Oriana's angry letter is a foundational document. It unleashes the chain of events that leads to marriage between the heirs to Britain and Gaul and the abdication of the British king, the key components of Montalvo's reversal of the medieval text's tragedy.

Letters and literacy are Oriana's primary means of egress from the domestic sphere. She makes occasional visits to her castle at Miraflores, but both friends (Amadís) and enemies (an evil enchanter) must abduct her when they need to move her from one place to another. The bulk of Oriana's travel occurs by proxy: her letters range the extent of the British nation and connect to allied states. Durín, Oriana's servant, carries the angry letter from Vindilisora ('Windsor') to Amadís at Ínsola Firme ('Firm Isle'), a peninsula that lies somewhere between Gaul and the kingdom of the giant Balán. ${ }^{104}$ One could argue that Oriana sends letters out of sheer necessity; if she did not, she could not communicate emotions or information (like her pregnancy) to her lover, who remains absent from the British court for the bulk of Books II and III. However, the circumspect option would have been to refrain from communicating at all; Elisena, in a similar situation, did not write to Perión between the time of their separation and her father's death. If one must communicate, sending a verbal message is safer than writing; Montalvo's Leonorina chooses this option in Las sergas de Esplandián. Oriana's letter demonstrates a degree of agency, as it deliberately visits her negative emotions upon Amadís. Yet it is an incomplete act of subversion, as it reiterates gendered expectations for chivalric women and formulates its command via the conventions of courtly love.

As with Elisena and Darioleta's waxed letter, Oriana's letter reflects emotional phenomena central to the themes of the work. The major moments of Amadís and Oriana's love affair reiterate the stages of Perión and Elisena's, and the text foregrounds Oriana's emotions. Like Elisena, Oriana is passionate, empathetic, and at times sad. Amadís and Oriana meet as children and fall in love at first sight. The text specifies Oriana's attachment to Amadís: 'Ella que lo amava de coraçon guardávase de fablar con él más que con otro [...] Mas los ojos avían gran plazer de mostrar al corazón la cosa del mundo que más amavan (She who loved him in her 
heart took care not to speak more to him than any other [...] but her eyes took great pleasure in showing her heart the thing in the world they loved best)'. ${ }^{105}$ This description focuses on Oriana's subjective experience and, unusually for this text, represents emotion as an interior state that can contrast an exterior state. The Galenic model of emotion, evident in the pregnancy episodes discussed earlier in this chapter, viewed emotions as a set of physical conditions; here, the text evinces a more modern view, in which emotions are an expression of psychology or identity. ${ }^{106}$

Once Oriana has learned of Amadís's high lineage, the two young people confess their mutual affection. In a scene that imitates Guinevere's meeting with Lancelot across the bars of a window, Amadís asks Oriana for merced ('favor'), which has a sexual connotation. She denies his request and asks him to keep their love secret 'por aquél señorío que sobre vos tengo (on account of that dominion which I hold over you)'. ${ }^{107}$ Though the reference to Lancelot and Guinevere makes courtly love an important generic model for this love affair, Amadis is out of the linguistic and temporal range for courtly love as a general category, and it demonstrates important differences from its medieval French models. Gaston Paris defined courtly love in the nineteenth century as 'an illicit, furtive, and extraconjugal liaison that placed the lover in the service of and at the mercy of a haughty and capricious lady'. ${ }^{108}$ It is impossible to know how the medieval Amadis treated the trope, but Montalvo's version emphasizes women's feelings as well as men's and directs the love affair toward marriage. Oriana only turns haughty and capricious when the rumor of Amadís's infidelity gives her a reason, and though she causes Amadís grief, she also displays her rationality by apologizing once the truth is revealed. For me, the pairing of Amadís and Oriana resembles the less conventional courtly love scenarios E. Jane Burns describes, which grant women conditional agency as 'a relational dynamic between individual protagonists and the social formations surrounding them'. ${ }^{109}$ For Burns, the most self-actualized ladies of courtly love do not display agency that is 'conscious, controlled, or full-blown'. Rather, their agency, like Oriana's, is situational and variable.

The essential difference between Oriana and the stereotypical ladies of courtly love is her deliberate recourse to writing. For Oriana, letters

105 Ibid., I: 269.

106 Plamper, The History of Emotions, 16, 33.

107 Rodríguez de Montalvo, Amadís de Gaula, I: 385 .

108 E. Jane Burns paraphrases Gaston Paris in Burns, 'Courtly Love', 28.

109 Ibid., 49. 
are weapons, and their construction is less a spontaneous response to stimuli than a performance of emotion meant to have the greatest possible effect on the recipient. For me, Oriana's letters, especially the angry letter, constitute what William Reddy terms 'emotives'. Reddy draws on both J. L. Austin's notion of the linguistic 'performative' (the speech act) and Judith Butler's theorization of gender performance to describe the motivations and effects of emotional communications. ${ }^{110}$ For Reddy, emotives both describe and alter emotional states; in a sense, emotive utterances bring emotions into being. Oriana's letter has a tripartite goal: to express Oriana's sorrow, to transmute it into anger, and to enact revenge on Amadís. The 'self-exploring and self-altering effects' of this letter suggest a potential link to agency and interiority. ${ }^{111}$ The letter is the reader's best indication that characters in Amadis de Gaula have psychological depth and the capacity for variations in thought and feeling. In my opinion, this letter is a successful emotive.

Oriana's composition strategy, morever, renders her an inscribed reader of several different sources, including Arthurian texts, the medieval ars dictaminis, and Ovid's Heroides. ${ }^{112}$ By attributing written letters to Oriana, Montalvo implies that she has the training in literary culture and cleverness necessary to craft them, making her stand out in a world in which book learning is rarely depicted. The most evident source for Oriana's angry letter is the scene from the prose Lancelot in which Guinevere dismisses Lancelot from her service. In both cases, a misunderstanding leads to an accusation of infidelity. Guinevere discovers Lancelot in bed with the daughter of King Pelles, and she tells him to leave the court: 'Ah, scoundrel [...] You disloyal traitor who have indulged your debauchery in my room and in my presence, get out of here, and take care never to come to any place where I am'. ${ }^{113}$ Lancelot then withdraws to a lonely isle, where his lovesickness becomes madness and nearly kills him. Lancelot appears guilty, but there are mitigating circumstances: the daughter of King Pelles pretended to be Guinevere and seduced Lancelot by deception. Amadís's culpability is more difficult to determine. If one considers all the variants of the episode, he is both guilty and innocent. Montalvo's text summarizes four medieval versions of rival queen Briolanja's attempt to seduce Amadís and then refutes them

110 Reddy, The Navigation of Feeling, 98, 111; Austin, How to Do Things with Words, 6; Butler, Gender Trouble, 33 .

111 Reddy, The Navigation of Feeling, 111.

112 Marín Pina, Páginas, 186; Avalle-Arce, El Amadís primitivo y el de Montalvo, 210.

113 Lancelot-Grail: The Old French Arthurian Vulgate and Post-Vulgate in Translation, III: 321. 
all. ${ }^{114}$ Depending on the reader's choice, interpretation, or memory, Oriana is either an irrationally jealous lover or a victim who seeks just revenge.

Montalvo's ambivalence toward Oriana reveals itself in the material features of the angry letter. Oriana's literacy demonstrates that she has received some version of the education that would be considered appropriate for young ladies of high status in fifteenth-century Castile. ${ }^{115}$ At one point, Montalvo depicts Oriana reading alone and silently, which points to the modernity of the episode: 'Oriana [...] estava muy triste a una finiestra de su cámara leyendo en un libro (Oriana [...] feeling rather sad, sat at one of the windows of her room reading a book) ${ }^{116}$ Oriana's literacy is not wicked in and of itself, but she uses her learning for the most corrupt purpose imaginable - to conduct a love affair. The writing conditions of the letter reflect both Oriana's intelligence and her capacity for deception:

Mudada su acostumbrada condición, que era estar en la compañía de aquéllas, apartándose con mucha esquiveza, todo lo más del tiempo estava sola, pensando cómo podría, en vengança de su saña, dar la pena que mereçía aquel que la causara; y acordó que, pues la presencia apartada era, que en absencia todo su sentimiento por scripto manifiesto le fuesse, y fallándose sola en su cámara, tomando de su cofre tinta y pargamino, una carta scrivió.

(In a departure from her usual habit, which was to be in the company of her ladies, she avoided them, spending her time alone thinking about how she could, in vengeance for her anger, give he who had caused her pain the punishment he deserved; she decided that, since he was not in her presence, she would reveal to him her sentiment in writing, and finding herself alone in her room, she took ink and parchment from her coffer and wrote a letter. $)^{117}$

This and other instances in which the women of Amadis interact with books, pen, and paper model the practice of literacy for a female audience.

114 In the variants, Briolanja imprisoned Amadís in a tower in order to coerce him into a liaison with her. In one version, Amadís stays in Sobradisa for a year and has twin children with Briolanja. See Rodríguez de Montalvo, Amadís de Gaula, I: 612-13; Avalle-Arce, El Amadís primitivo y el de Montalvo, 163 .

115 Nicasio Salvador Miguel's research into the early life of Isabel la Católica has revealed that the princess received early training in literacy, arithmetic, music, dance, horseback riding, Christian devotion, history, and government. See 'Instrucción', 114-20.

116 Rodríguez de Montalvo, Amadís de Gaula, I: 749.

117 Ibid., I: 676 . 
The words esquiveza ('secrecy'), vengança ('vengeance'), and saña ('anger') point to negative behaviors, and Montalvo appears to disapprove of Oriana's sentimental decisions even as he narrates them. Yet, by depicting her writing practices in such detail, he signals to potential female readers that literacy itself is acceptable for women.

Oriana's letter allows her to circumvent conventional restrictions on women's behavior, and it also has the power to render an act of communication permanent. The impact of Guinevere's verbal command to Lancelot fades over time, but Oriana's written command remains fresh. Oral expression might be a choice for Guinevere, but it is also possible that in the prose Lancelot, she is illiterate. This is not to say that the world of Lancelot is entirely without literacy. In the Lancelot-Grail cycle, letters and reading are associated with the Lady of the Lake and her milieu. ${ }^{118}$ The water fairy teaches Lancelot to read, which allows him to complete the challenges at Douloureuse Garde ('Dolorous Gard'). Arthur, Gawain, and Guinevere, meanwhile, use clerks and monks to read for them. ${ }^{119}$ For the Lady of the Lake, for Lancelot, and for Oriana, literacy equals power.

Oriana's letter, written in isolation, is one of the few moments in Amadis that could be said to have an interior focus. Even though Oriana's subjectivity is bounded by genre and gender conventions, she has unique thoughts and feelings. In a development parallel to the Iberian sentimental novel, the letter allows her feelings to pass to Amadís. The blow is delivered when Amadís interacts physically with the letter: 'No parecía sino ser fecho pedaços su coraçón (It seemed as though his heart had been torn into pieces).' ${ }^{120}$ Oriana names herself on the envelope as la donzella herida de punta de espada por el coraçón (the maiden wounded by a swordpoint through the heart)'; when Amadís tucks the letter into his clothing, he faints, as though he too has received a mortal wound. ${ }^{121}$ María Aguilar Perdomo characterizes the depressive state into which Amadís then sinks as typical for Iberian romance; angry letters from ladies to their knights habitually pass on negative feelings. ${ }^{122}$ Oriana's is the first and most influential of these instances, most of which were modeled on this episode.

The strength of Amadís's reaction also reflects Oriana's mastery of the hierarchical language of ars dictaminis, a set of recommendations for letter

118 Lancelot du Lac, 96.

119 Lacy, Lancelot-Grail Reader, 144.

120 Rodríguez de Montalvo, Amadís de Gaula, I: 679.

121 Ibid., I: 680, I: 677.

122 Aguilar Perdomo, 'La penitencia de amor caballeresca', 132. 
writers that circulated in Europe from the twelfth to the fifteenth century. ${ }^{123}$ Gideon Burton notes that this bureaucratic formulary served as a model for private as well as public letters. ${ }^{124}$ The most salient feature of the ars dictaminis is its emphasis on epistolary decorum. ${ }^{125}$ The formulary coalesced by the end of the thirteenth century into a five-part structure, composed of a salutatio or greeting, a captatio benevolentiae meant to elicit the reader's goodwill, a narratio stating the letter's business and/or a petitio making a request, followed by a brief conclusio. ${ }^{126}$ Each part of the letter attends to hierarchy. Letters from an inferior writer to a superior addressee have a lengthy salutatio and captatio benevolentiae, while letters from superior to inferior have brief or absent greetings and emphasize petitio. In the latter case, the request is a command and little flattery is required. ${ }^{127}$

Oriana's use of ars dictaminis positions her as superior to Amadís and thus capable of issuing an order. She includes a salutatio but identifies herself pseudonymously because she fears discovery by third parties. Oriana identifies her addressee by name, as 'el falso y desleal cavallero Amadís de Gaula (the false and disloyal knight Amadis of Gaul). ${ }^{128}$ If the letter were to go astray, it could damage Amadís's reputation. This is a captatio malevolentiae, an invocation of ill will, rather than the expected flattery of the captatio benevolentiae. Oriana then narrates the rumor of Amadís's infidelity with Briolanja. She follows with her petitio, 'no parescáis ante mí ni en parte donde yo sea (do not appear before me or in any place that I am)', which echoes Guinevere's dismissal of Lancelot. Oriana's letter ends with a conclusio that projects the end of her life: 'Plañiré con mis lágrimas mi desastrada ventura y con ellas dar fin a mi vida, acabando mi triste planto (I will lament my ill-starred fortune with my tears and with them end my life, ending my sad complaint), ${ }^{129}$

Oriana's narratio is scant, as her main business is the transfer of emotion. In order to develop Oriana's affective landscape, Montalvo draws on a second well-known correspondence model, Ovid's Heroides. Montalvo might have had access to Ovid either in the original Latin or through Castilian translations and imitations. Juan Rodríguez del Padrón's fifteenth-century version

123 Burton, 'From Ars Dictaminis to Ars Conscribendi Epistolis', 88; Camargo, Ars dictaminis, 20.

124 Burton, 'From Ars Dictaminis to Ars Conscribendi Epistolis', 93.

125 Ibid., 88.

126 Camargo, Ars dictaminis, 22-23.

127 Ibid., 23.

128 Rodríguez de Montalvo, Amadís de Gaula, I: 676.

129 Ibid., I: 677. 
of the Ovidian text, El bursario (The Bursar, c. 1438), is both a translation of Heroides and a proto-sentimental novel..$^{130}$ The narrative epistles of Heroides resemble this portion of Amadis in that they recount the suffering of women at the hands of men. Ovid's letters are rich in psychological complexity, but they are incomplete communications; only three letters (those from men to women) have replies. ${ }^{131}$ The epistles also undermine their own content through insistent references to the frail, passion-ridden female body.

The Ovidian concept of emotion has much in common with Galen's humoral theory; emotions are internal but physical, and in Ovid, wounding the body seems to let them out. Ovid's fictionalized letter writers cannot wound the men who have wronged them, so they wound their bodies instead. Phyllis, abandoned by a lover who vowed marriage, declares: 'I wish that I could plunge a sword in my heart so that my blood could be poured out'. ${ }^{132}$ Oenone, a nymph abandoned by Paris, seeks to destroy the physical features men value: 'I tore the clothes away from my breasts and beat my hands against my flesh; my long nails tore at my tear-stained cheeks.' ${ }^{133}$ Dido, abandoned by Aeneas, describes her 'shoulders bent in grief, hair undone, all stained with blood'. ${ }^{134}$ Hermione, the unwilling bride of Pyrrhus, refuses to hold back her tears: 'My face swells with fury [...] I can pour out rage so that tears like a stream cover my bosom. Only these do I have, and freely do I let them go; my cheeks are always wet and ugly from their unending flow'. ${ }^{135}$ Whether wife, lover, daughter, or slave, Ovid's female letter writers lack the power to resist the commodification of their bodies on the erotic market, and their only means of revenge - or of emotional expression-is to ruin the beauty and thus the exchange value of the body.

Oriana believes herself to be almost as helpless as the women of Heroides at the time of the letter's writing. Oriana's situation is most similar to that of Phyllis, and she uses the same image as the Ovidian speaker to identify herself on the envelope, the sword piercing the heart. Oriana's pain has compromised her health and beauty, and by extension her worth on the marriage market. The princess makes reference to la flaca mano (the weak hand)', 'el triste coraçón (the sad heart)', 'mis sospiros y passiones (my sighs and passions)', and 'mis lágrimas (my tears)' ${ }^{136}$ Oriana represents herself

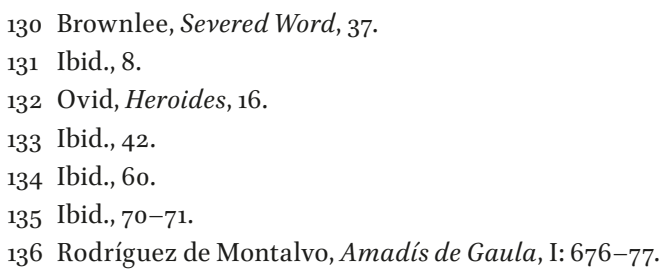


as a 'cativa mujer (wretched woman)' who has been 'burlada y desechada (deceived and discarded)'. ${ }^{137}$ These images of the suffering body are at odds with the hierarchy established by the ars dictaminis.

The tension of ars dictaminis and Heroides as correspondence models further underscores the ambivalence with which the text represents Oriana. Heroides serves to contain the wrong a woman has suffered within a frame that exposes a man's crimes but exempts him from the consequences. Montalvo explicitly compares Oriana in her jealousy to Ovid's Medea, a woman whose very name evokes evil. ${ }^{138}$ Yet the Medea of Heroides is an equivocal figure. Her claim against Jason is just, and she has not yet committed her famous infanticide. She names herself 'Queen of Colchis' and reminds Jason that in order to help him, she forfeited her kingdom. ${ }^{139}$ Oriana believes that Amadís has seduced and abandoned her, just as Jason seduced and abandoned Medea. The comparison to Medea suggests that Oriana might be evil, but it also leaves open the possibility that Oriana's feelings might be justified.

The 1508 text retains some hesitance over Amadís's fidelity, and in order to exonerate him, Montalvo has him pass through a magical device, the Arco de los leales amadores ('Arch of Loyal Lovers'), which produces beautiful music when it encounters faithful hearts. ${ }^{1{ }^{10}}$ As Williamson notes, 'Montalvo's response to technical difficulties or aesthetic doubts is to invent a new character or a new episode in the hope of dissimulating the problem.. ${ }^{141}$ David Quint points out that Amadís never accuses Oriana of wrongdoing. ${ }^{142}$ Amadís's reply poem is just as ambivalent as the rest of the episode: 'Pues se me niega vitoria / do justo m'era devida [...] es gloria morir la vida (Because a just victory is denied to me [...] death will be my glory).'.43 Amadís's poem is both a gesture of obedience to an unreasonable lady of courtly love and a tacit acceptance of a just punishment from a queen.

Whether or not he feels guilt over the Briolanja situation, in submitting to Oriana, Amadís rejects the misogynist ideology that would render the princess an object of derision. The misogynist view is well represented elsewhere in the episode. The hermit tells Amadís not to trouble himself over

137 Ibid., I: 677 .

138 Ibid., I: 606.

139 Ovid, Heroides, 106.

140 Pinet argues that the 'mechanical artifices' at Ínsola Firme are, like Oriana's letter, Montalvo's own invention. See Archipelagoes, 84.

141 Williamson, The Half-Way House of Fiction, 62.

142 Quint, Cervantes's Novel of Modern Times, 33.

143 Rodríguez de Montalvo, Amadís de Gaula, I: 731. 
an 'hecho de mugeres, que se ligeramente gana y pierde (a matter of women, who are easily won and easily lost)'. ${ }^{144}$ Oriana's servant Durín accuses her of murdering Amadís. ${ }^{145}$ Yet Amadís himself, the moral center of the romance that bears his name, declares that 'Oriana, mi señora, nunca erró en cosa ninguna (my lady Oriana never erred in anything). ${ }^{146}$ Amadís persists in adhering to the worldview in which Oriana is sovereign: 'Si yo muero es con razón, no porque lo yo merezca, mas porque con ello cumplo su voluntad y mando (If I die it is for a reason, not because I deserve it, but because in so doing I comply with her will and command)'. ${ }^{147}$ It would be tempting to view Amadís as a mere echo of Lancelot here, but there is more in this episode than the usual construction of courtly love, in which the man's subjectivity is paramount and women exist as inscrutable objects. ${ }^{148}$ For me, courtly love is not the only motif at work, as Oriana's thoughts and feelings provoke the episode; it is she who acts, and Amadís who reacts. Heroides allows Oriana to transmit a strong dose of suffering, and ars dictaminis allows her to do so without surrendering her superior position in the romance hierarchy. These references are possible because of Oriana's implied education; she knows the letter formulary, and the allusions position her as an inscribed reader of Heroides and Arthurian tradition. In addition, the extradiegetic reader knows that Oriana's perspective is important to the text because both of her letters are cited and Amadís's is not; only his oral ballad makes an appearance. The combination of inscribed reading and writing thus makes Oriana an unusual lady of courtly love, one capable of at least a conditional agency.

Oriana's letter, moreover, is a more effective communication than even the letters of Heroides because Montalvo imbeds it in a bi-directional communicative setting. When Oriana learns the truth, she sends a conciliatory letter to Amadís that follows neither the model of ars dictaminis nor Heroides. The second letter is a simpler composition that attributes her mistake to 'gran sobra de amor (great excess of love)'. ${ }^{149}$ Oriana refers to Amadís as amigo ('friend' or 'lover') twice in the letter; the word is fond and familiar, as opposed to the formal cavallero ('knight') she used in the angry letter. The hierarchical polarities have changed as well. Oriana now represents herself as 'persona culpada que con humildad su yerro conosce (a guilty

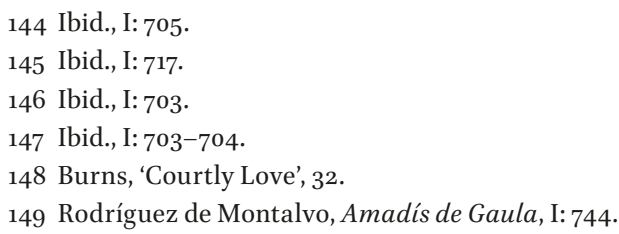


Figure 3 A messenger reports to Oriana. From the 1526 Sevilla edition of Amadís de Gaula by Jácome Cromberger.
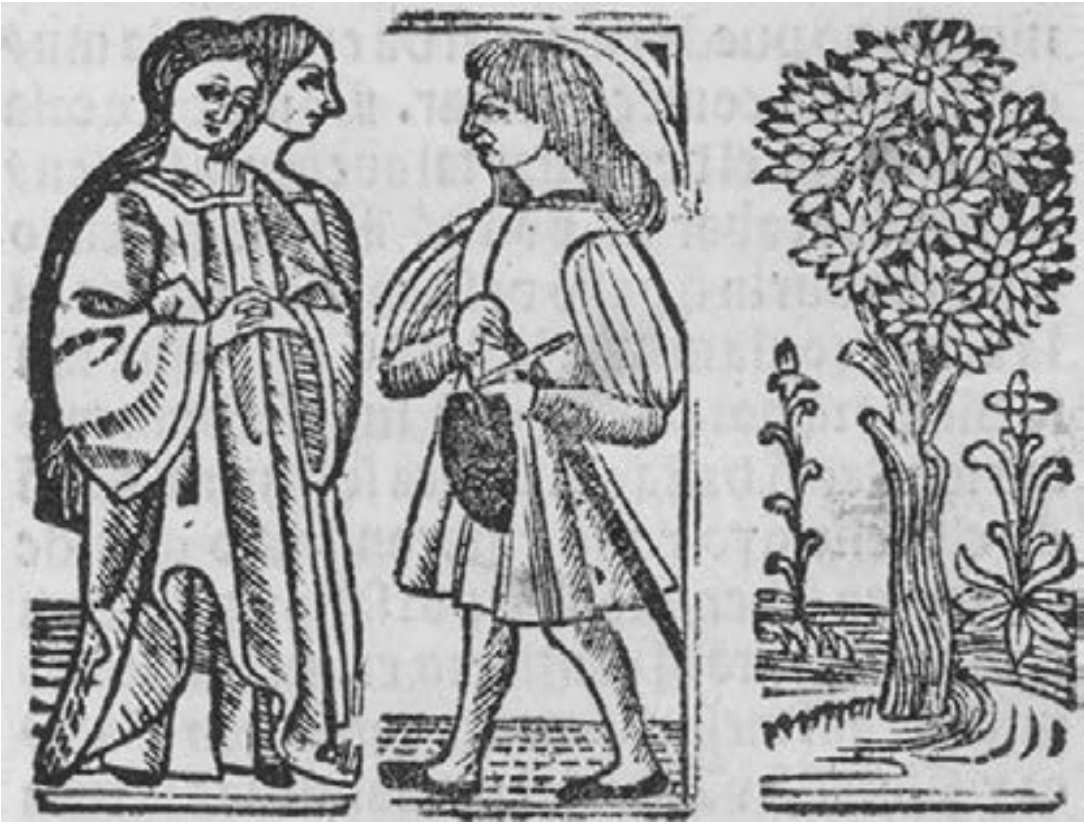

person who recognizes her error with humility)' equal to or lower than the friend to whom she writes. ${ }^{150}$ Amadís replies to this letter, accepting the apology, though his missive is not cited.

Oriana's second letter reconciles a sentimental relationship, but it also hints that Oriana possesses the virtues of a monarch. Humility can be an attribute of the strong as well as the weak, and Oriana here rules her subject with clemency. Her ability to admit fault, moreover, indicates that she will be a better ruler than her stubborn father, Lisuarte. Throughout the rest of the text, the partnership of Oriana and Amadís persists on terms of courtesy and relative equality. Each defers to the other, and in their joint reign, they appear to act together. Oriana's capacity for remorse also redeems her with Montalvo. The narrator of Book IV observes: 'Esta Infanta siempre fue la más mansa, de mejor criança y cortesía, y sobre todo la templada humildad que en su tiempo se falló (This princess was always the most gentle, with the best manners and courtesy, and with the most temperate humility of any woman of her time)'. ${ }^{11}$ Montalvo was almost certainly the author of this 
Figure 4 Oriana writes to her mother. From the 1526 Sevilla edition of Amadís de Gaula by Jácome Cromberger.

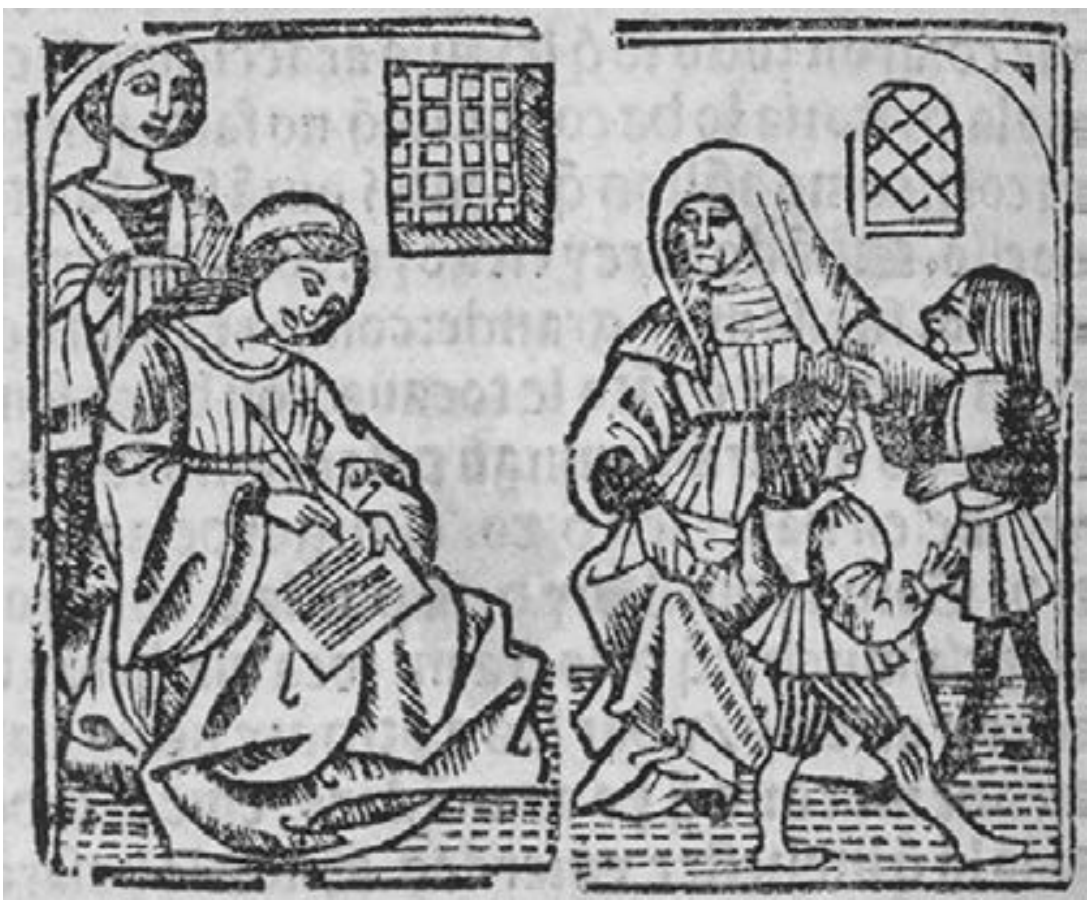

description, as it occurs during the revised conclusion to Amadís. As a lover, Oriana has her faults, but as a queen and bride to Amadís, she is exemplary.

Oriana's third cited letter, a diplomatic appeal to her mother, Brisena, arises out of the complications of her reconciliation with Amadís and reflects her newfound humility. After receiving Oriana's apology letter, Amadís seeks out his beloved at her castle at Miraflores. Esplandián is conceived during the characters' reunion, and the child's existence puts his parents on the path to public marriage. Indeed, Oriana becomes the ally of her secret husband rather than her father from this point. King Lisuarte, ignorant of the marriage pact between Amadís and Oriana, attempts to force his daughter to marry the Roman emperor and renounce her claim to the throne of Britain in favor of her younger sister. Amadís abducts Oriana and shelters her in Ínsola Firme to save her from this fate, which in turn sparks civil war. In order to protect the bright future of Britain and Gaul, Montalvo must find a way to make peace between Lisuarte and Amadís. A letter from Oriana is the first attempt at reconciliation. 
Under siege at Ínsola Firme, Oriana writes a letter to her mother that returns to the models of ars dictaminis and Heroides, hoping to persuade Brisena to broker a truce. In terms of ars dictaminis, Oriana is now a suppliant, and her diction is humble. Heroides, as before, conditions Oriana's expression of emotion. The letter begins with a greeting that declares the status of both parties: 'Muy poderosa reina Brisena, mi señora madre: Yo la triste y desdichada Oriana, vuestra hija, con mucha humildad mando besar vuestros pies y manos (Most powerful queen Brisena, my lady mother: I, the sad and unlucky Oriana, your daughter, with great humility kiss your feet and hands)'. ${ }^{152}$ Oriana's salutatio and captatio benevolentiae cultivate Brisena's goodwill through expressions of filial piety. After a brief narration of the events that led to her abduction, Oriana appeals to her mother's compassion: 'Si [...] haviendo piedad de mí no procuráis el remedio, no solamente yo, mas muchas otras gentes que culpa no tienen, con muy crueles y amargas muertes fenescerán sus vidas (If [...] you, taking pity on me, do not find a solution, not only I, but many other innocent people will die cruel and bitter deaths)'. ${ }^{153}$ Oriana's petitio is simple; she wants her mother to ask for Lisuarte's mercy. Her goal is to end, not win, the civil war.

The emotional vocabulary of Heroides is also important to Oriana's letter to Brisena. This time, Oriana's plight resembles that of Ovidian heroines Hermione, Hypermnestra, and Canace, who suffer at the hands of their fathers. Hermione's predicament, an unwanted betrothal to Achilles's son, Pyrrhus, is most similar to Oriana's. Oriana recalls Hermione by referencing her anguished heart and many tears. ${ }^{154}$ The missive to Brisena is a sincere but calculated emotional appeal to a family member who happens to be the wife of a monarch. After reading it, Brisena asks Lisuarte for clemency: 'Fincó la Reina los inojos delante dél llorando, y díxole: Señor, leed esta carta que vuestra hija Oriana me ha embiado, y aved piedad della y de mí (The Queen knelt before him weeping and said: my Lord, read this letter that your daughter Oriana sent to me, and take pity on her and on me).' ${ }^{155}$ The letter constitutes a negotiation between queens that circumvents a negotiation between kings. Amadís and Lisuarte will never understand each other, but Brisena, unlike her husband, is capable of acting in the best interest of

152 Ibid., II: 1364.

153 Ibid., II: 1365 .

154 Ibid., II: $1364-65$.

155 Ibid., II: 1366. 
the family and the nation. If matters had been in her hands, the war would have ended at this moment.

Oriana's letter to her mother is meant to unite the family, as Darioleta's letter did for Perión, Elisena, and Amadís. Lisuarte, however, is immune to good advice. ${ }^{15}$ From his perspective, absolute monarchy justifies any action he might take: 'Yo, seyendo lugarteniente de Dios, a Él y no a otro ninguno soy obligado de dar la cuenta de lo que por mí fuere fecho (I, as the representative of God on Earth, am obliged to give an account of my deeds only to Him)'. ${ }^{157}$ Oriana's letters show that she will be a very different kind of monarch. She can re-evaluate a deeply held belief based on new evidence, negotiate with family and allies, and make peace instead of war. Lisuarte, perhaps recognizing at last his daughter's potential, abdicates to her in Montalvo's sequel, telling his people: 'Para vuestro reparo, dexo a mi fija Oriana con este cavallero, su marido (As your refuge, I leave you my daughter, Oriana, and this knight, her husband)' ${ }^{158}$ Lisuarte's diction reveals Oriana's sovereignty; it is clear that she is the monarch and Amadís is her consort. She will be the solution to the difficulties Lisuarte's autocratic style of leadership caused.

\section{Writing the Future}

Although Oriana's letter to Brisena gives us a picture of the kind of ruler she will be, the letter alone cannot guarantee that Oriana will succeed her father. Another woman, this time an enchantress, must intervene through the written word in order to broker a lasting peace and prevent Lisuarte from disinheriting Oriana. Urganda la Desconocida ('the Unknown'), a literate female magician who has been involved with the ruling families of Britain and Gaul since the birth of Amadís, uses letters of prophecy as a form of statecraft. She succeeds in influencing Lisuarte where family members and counselors fail. Urganda's personal network, moreover, is comprised of women, and she connects the monarchies of Britain and Gaul through her relationships with the women, children, and adolescents associated with the two kings.

156 Pierce credits Brisena and Oriana with forging the eventual peace between Britain and Gaul; if this is true, the letter has a delayed impact. See Amadís de Gaula, 34.

157 Rodríguez de Montalvo, Amadís de Gaula, II: 1370.

158 Rodríguez de Montalvo, Las sergas de Esplandián, 399. 
The degree to which Urganda actually practices magic is debatable. She does possess some magical objects, including a pot of ointment that allows her to change her apparent age, rings that protect the wearers from enchantment, and a book that contains a sleeping spell. Her serpent boat travels swiftly and appears from nowhere. Her home of Ínsola no Fallada ('Undiscovered Isle') is difficult to reach, but it does not seem to be under water or exist in a parallel dimension. Urganda and her nieces are able to heal severe wounds and can read ancient Greek. Many of these marvels might be due to superior technology or learning rather than magic. Urganda's prophecies sometimes signal future events, but often they merely communicate current events across distance. Urganda's legion of unnamed damsels carry messages across the kingdoms of Amadis, and perhaps they also report information to their mistress. Urganda might be clairvoyant, but it is also possible that she is a spymaster.

Whereas Elisena and Oriana are more modern in their forms of literacy, literate enchantresses are one of the oldest representations of female scholarly activity in the romance tradition. The character of Urganda la Desconocida appears to be based on the Lady of the Lake, Lancelot's fostermother and teacher. The Lady of the Lake is often represented as a fairy, and her dwelling-place is described either as the bottom of a lake or the magical isle of Avalon. Carlos Alvar explains that the Lady, sometimes named Niniane or Viviane, first appears in Chrétien de Troyes's twelfth-century Le chevalier de la charrette (The Knight of the Cart). In the anonymous thirteenth-century Lancelot, she plays a larger role, serving as a foster mother for Lancelot and his cousins. ${ }^{159}$ Elspeth Kennedy notes 'the Lady of the Lake's careful education of Lancelot for knighthood', during which the young boy learns letters, the arts of war, and the chivalric code. ${ }^{160}$ Though Urganda is not a surrogate mother for Amadís, she influences his upbringing almost as much as the Lady of the Lake influenced Lancelot's.

In further connection to the Lady of the Lake, Urganda is literate, and she delivers many prophecies as cartas ('letters') or scriptas ('writings'). When a prophecy comes true, Urganda insists that it be read to the public, thereby increasing her standing in the community. Urganda serves as a surrogate of the author, signposting important events for the reader and creating anticipation. Urganda's writings also influence public policy. On the eve of battle between Britain and an alliance of giants and Irishmen, Urganda sends two brief missives concerning the princes of Gaul. They bear a structural

159 Alvar, El Rey Arturo, 114.

160 Kennedy, Lancelot and the Grail, 14. 
and linguistic similarity to Oriana's letters, and their placement occurs soon after the reconciliation of Oriana and Amadís. Both of these features suggest that Montalvo wrote Urganda's letters. The first letter informs Lisuarte that he will win the battle but that the knight Beltenebros (Amadís in disguise) will lose his name. Lisuarte believes that Beltenebros will die; in fact, he will unmask himself and resume his true identity. In her conclusio, Urganda seems to urge the king to change his battle plans: 'Cata, Rey, lo que farás, que lo que te embío dezir se fará sin duda ninguna (Take heed, King, of what you will do, for that which I say will come true without any doubt)'. ${ }^{161}$ The second letter, addressed to Amadís's younger brother, Galaor, tells him that he will suffer a serious wound. ${ }^{162}$ Galaor is Lisuarte's dedicated knight, and he shows his lord the letter from the enchantress. Urganda understands the relationships among the parties, and she must know that her second letter will reach the king. Lisuarte, to his credit, discourages the knights from participating in the battle. Citing their honor, they refuse.

Urganda's prophecies might seem null and void, as no one takes action based on her warnings. Yet prophecies - especially women's propheciesrarely alter characters' behavior. Female seers in Iberian romance possess an equivocal sort of power. They can provide information about the past, present, or future, but, like the archetypal prophetess Cassandra, they do not have the power to make others believe them. Amadís/Beltenebros and Galaor cannot help but adhere to the chivalric code, which requires bravery in the face of danger. Fortunately, in Montalvo's use of prophecy, the danger such messages index can usually be avoided by other means. The prophecy about Beltenebros is a riddle and requires no action. Galaor is, in fact, at risk, but Urganda whisks him away for healing the moment he receives his wound. What, then, was the purpose of these letters?

The answer concerns their common reader, King Lisuarte of Britain. The king, at the zenith of the chivalric hierarchy, can act more freely than his knights. This king in particular considers his own power to be absolute. Urganda sends these two prophecies in order to influence Lisuarte's opinion of the two princes of Gaul. Amadís has never been Lisuarte's favorite, as early on the knight dedicated himself to Queen Brisena rather than to the king. 'Beltenebros', however, will earn favor by saving Lisuarte's life during the battle. Galaor, meanwhile, has long been among Lisuarte's preferred advisors, and the threat to his life makes him even more precious. Urganda may hope that the stubborn Lisuarte will listen to Galaor's wise counsel. 
Perhaps disappointingly, the king makes no changes as a result of these prophecies. Urganda, however, receives public recognition as one who sees and one who knows. Lisuarte has the prophecies read to the entire court: 'El Rey las fizo traer y leer a todos, y vieron como todo aquello que en ellas se dixera avía enteramente complido (The King had them brought and read to everyone, and they saw how everything told in them had come true)'. ${ }^{163}$ The prophecies establish Urganda's authority in the eyes of the people, and eventually Lisuarte will indeed recognize the worth of the princes of Gaul, as Urganda had intended. This episode positions Lisuarte as an inscribed reader of Urganda, yet his reception of her letters is ambivalent, as one would expect considering the gender positioning. Montalvo appears to consider writing a kind of agency on a woman's part that can be rendered futile, as men may read women's words and ignore them.

Indeed, Lisuarte heeds no one but himself. When he decides to disinherit Oriana and marry her to a foreign monarch, Galaor warns Lisuarte that if he does so he will become an exemplum of the bad king 'perpetuamente en sus libros y crónicas (perpetually in books and chronicles)'. ${ }^{164}$ Writing, according to Galaor, stands for permanence, and he levels it here as a threat. He also offers to preserve his advice in writing: 'Dexaré un scripto de mi mano, que fagáis mostrar a todos vuestros hombres buenos, de lo que os he dicho (I will write down in my hand that which I have told you, so that you may show it to all good men)'. ${ }^{165}$ Interestingly, Galaor uses the same techiques Urganda did to transmit wisdom, suggesting that the strategy itself is gender neutral. Perhaps Galaor hopes that Urganda's gender influenced the reception, and that his case will be different. Yet Lisuarte ignores Galaor, just as he will ignore his daughter's tears and diplomatic letter. In another rare moment of gender neutrality, Lisuarte, as a reader, fails to benefit from the writings of men or women. Letters from Urganda, not Galaor, will ultimately persuade the stubborn monarch, but only when an object lesson accompanies them.

Urganda knows everything that is going on in the romance world, including Oriana's deepest secrets and the movements of lions and hermits. She knows what Lisuarte's kingdom lacks: his kingdom has no male heir, and the succession remains in debate. Urganda manipulates the characters into a tableau that offers Lisuarte the solution to succession: the marriage of Amadís and Oriana. Their son Esplandián, who inherits all of his parents' virtues and none of their flaws, will give everyone, including Lisuarte, confidence in a 
new dual monarchy. Urganda knows more about the origin of Esplandián than any other person, including the boy himself. She consults with Oriana after her liaison with Amadís at Miraflores, using a magical book to place Oriana's companions in a deep sleep so that she can issue a prediction about Oriana's pregnancy. ${ }^{166}$ Oriana herself has not yet realized she is pregnant; either Urganda is a true seer or she has heard of Amadís and Oriana's long stay at Miraflores from her spies and is making an educated guess.

By some inscrutable means of observation, Urganda also learns what happens to the child after his birth. Once Esplandián is born, Oriana orders the Damsel of Denmark and her brother, Durín, to take him to a friendly abbess. However, during their journey through the wilderness, a lioness scares the Danish servants and they abandon the child. Instead of eating the tender morsel, the lioness adopts the human infant and allows him to nurse alongside her cubs. The hermit Nasciano, already a friend to the lioness, takes the child and feeds him on sheep's milk until he can find a human nurse. ${ }^{167}$ Urganda sends a cryptic prophecy about this event to the court long before Oriana can discover her child's fate.

Urganda's third letter-prophecy encourages Lisuarte to reunite the British royal family, but he does not understand it until many years after it is delivered. Soon after the episode with the lioness and the hermit, a letter arrives at court 'çerrada con una esmeralda muy fermosa [...] passavan por ella unas cuerdas de oro, y tenía unas letras enderredor que dezían: 'Este es el sello de Urganda la Desconocida' (sealed with a beautiful emerald [...] there passed through it cords of gold, and it had letters around it that said: this is the seal of Urganda the Unknown).' ${ }^{68}$ This letter, like Oriana's angry letter, has specific material characteristics that certify its provenance and authenticity. The cords, seal, and emerald render it an official rather than a personal missive. Urganda's letter states that the child brought up by three nurses will bring about peace between Lisuarte and Amadís. Incredibly, no one ever guesses the child's identity, despite the fact that the foundling Esplandián, nursed by lioness, ewe, and human, comes to live at Lisuarte's court when he is six years old. Oriana recognizes her son by his birthmark and admits him to her household, but even she does not connect him to the prophecy. ${ }^{169}$

When the meaning of the prophecy is revealed, King Lisuarte at last agrees to make peace with Amadís. Even as Lisuarte's forces besiege Ínsola Firme,

166 Ibid., I: 855 .

167 Ibid., II: 1007-1008.

168 Ibid., II: 1107.

169 Ibid., II: 1113 . 
the hermit Nasciano tells Lisuarte - at Oriana's urging — that Esplandián is his grandson and that Amadís and Oriana are secretly married. At that very moment, the boy rides into the war camp with a letter from Brisena. Esplandián has already begun to show promise, and the fact that he will be the eventual heir to Britain seems to validate the marriage of Amadís and Oriana. When Lisuarte had first read the prophecy of the three nurses, he had declared: 'la sabiduría desta muger no se puede pensar ni escrivir (the knowledge of this woman cannot be thought about or written down)'. ${ }^{170}$ The statement is ironic, as Urganda habitually writes down the fruits of her knowledge. Indeed, the written nature of the prophecy makes it durable, able to influence events years after Urganda communicates it.

Urganda's prophecy proves the only effective means of controlling the bad king. Even at this point, Lisuarte could have insisted on continuing the war or attempted to enforce the law of Scotland against Oriana. However, this time the king yields to the weight of prophecy, making it come true through his own actions. Lisuarte never recovers from his symbolic surrender. He continues to express dissatisfaction at losing the alliance with Rome, and he appears to realize that his rule has become superannuated. ${ }^{171}$ The old king takes to going out alone and is soon captured by evildoers. As soon as he is rescued, he formally abdicates to his daughter. Lisuarte's autocratic vision of monarchy is not the future of Britain and Gaul. The new, collaborative monarchs, known for their compassion and sensitivity, will govern with an eye to alliance, mercy, and justice. Writing and other acts of literacy have enabled their reign and, perhaps unsurprisingly, letters of diplomacy will be among their primary levers of power in Montalvo's sequel.

\section{Writing the End of Chivalry}

One final letter of prophecy initiates the generational shift that occurs at the end of Amadís de Gaula. As the work concludes, the torch of love and adventure passes from Amadís and Oriana to Esplandián. During the search for the missing Lisuarte, Urganda delivers to Amadís a prophecy encouraging him to retire from knight errantry in order to dedicate himself to governing Britain alongside his wife. When he grows up, Esplandián will be the one to undertake the long journey to the Holy Land, where Lisuarte has been 
held captive. At this point, Perión still occupies the throne of Gaul, and the union of the two countries lies a decade or so in the future.

The fragile alliance of Britain and Gaul depends on the personalities of Amadís and Oriana, who now must turn their attention to ruling the kingdom. Urganda visits Amadís to console him upon the disappearance of his fatherin-law, and when the enchantress leaves, Amadís finds a letter in his hand that tells him, gently, that his time of youthful energy is over: "Toma ya vida nueva con más cuidado de governar que de batallar (Begin now a new life with more care for governance than for battles)'. ${ }^{12}$ The new life for Amadís the character is the end of Amadis the book. From this point forward, Oriana and Amadís become the matriarch and patriarch of sequels that chronicle the deeds of their descendants. Oriana fades from the narrative, but so does Amadís; their reign is too stable to be of much interest. One could argue that Oriana becomes subordinate to her husband, but in my view, they merely meld together in their retirement. Montalvo enchants them at the end of the Sergas into an Arthur-like living death, while Feliciano de Silva grants the pair a long-life enchantment that allows them to watch their grandsons, great-grandsons, and great-great-grandsons grow up. In Florisel de Niquea Part IV, Silva reveals that Amadís is two hundred years old, white-haired, just as spry and handsome as ever, and still ruling Britain and Gaul alongside Oriana. ${ }^{173}$

Urganda's final prophecy also predicts the long afterlife Amadis de Gaula will enjoy in early modern European literature. The time of action is over for Montalvo's Amadís and Oriana, but they survive in new forms and new contexts. Imitators of the work in Spain interpolate Oriana and Amadís as exemplary figures whose story can be divided into iterable motifs. Citations of Amadis are sometimes direct, as in the case of continuations by Montalvo, Ruy Páez de Ribera, Juan Díaz, Feliciano de Silva, and Pedro de Luján. They can also be subtle, as in Beatriz Bernal and Cervantes, for whom Amadis becomes the warp on which to weave a complex tapestry of citation, imitation, and innovation. Montalvo's authorial persona is forgotten after twenty years of printing, but the representation of women's lives and women's literacy in Amadís survives in sequels, imitations, translations, and adaptations. ${ }^{174}$ The link between women and textuality persists, and indeed, for Beatriz Bernal, reading becomes the companion of the chivalric adventure.

172 Ibid., IV: 1763.

173 Silva, Florisel IV, 145r; Martín Romero, 'Amadís de Gaula humanizado', 263.

174 Editions of Amadis in the sixteenth century, including the influential 1526 Sevilla, tend to misspell Montalvo's name as Garci Ordóñez de Montalvo. French translator Nicolas de Herberay names Montalvo only as the Spanish author, and English translator Anthony Munday appears to believe that Herberay is the original author of the work. 



\section{Women's Literacy in Beatriz Bernal's Cristalián de España}

The half-century after the publication of Garci Rodríguez de Montalvo's 1508 Amadis de Gaula witnessed a vogue for chivalric romance crafted in its image. ${ }^{1}$ Montalvo himself, Ruy Páez de Ribera, Juan Díaz, Feliciano de Silva, and Pedro de Luján explicitly continued Amadís, and in the process they diminished the work's independent-minded female characters. Even Feliciano de Silva's ludic sequels celebrated the freedom of men, not women. ${ }^{2}$ Beatriz Bernal's Cristalián de España, first printed in 1545 in Valladolid, goes against this trend, crafting new female characters who are in some ways more subversive than their models. Though Bernal does not continue the story of Amadís and Oriana, she expands on the tacit promise Amadís de Gaula made to literate women by proposing a more egalitarian division of chivalric labor. In Amadis, the plot is gendered and bifurcated: men fight and women write. However, in Cristalián de España, characters of both genders write and act. Bernal also expands the number of literate female characters, suggesting that reading and writing women are the rule and not the exception. These women, like their counterparts in Amadís, exercise a conditional agency through their literary practices. Bernal's literate women draw heavily on available models, not just from Amadís, but also from Montalvo's sequel Las sergas de Esplandián and other chivalric works, including Tirant lo Blanch and La crónica troyana. Bernal's allusions to these texts in a sense 'read' the women depicted therein, and intertextual borrowings complicate her depictions of women's literacy. The result is a romance world in which women's literary practices are both more frequent and more risky than in the source works. Women use reading and writing for good and evil, and their attempts at accomplishing a communicative goal through written texts often fail. Women, however, are primary rather than secondary players in Cristalián, and the range of roles and functions they undertake speaks to Bernal's egalitarian notion of chivalric romance as a genre.

On the surface, Beatriz Bernal, as a sixteenth-century woman of the bourgeoisie, does not seem a good candidate for chivalric authorship. Yet

\footnotetext{
1 Chevalier counts 267 editions of romances of chivalry in Spain between 1501 and $165^{0 .}$ Chevalier, Lectura y lectores, 66.

2 Cravens, 'Feliciano de Silva', 29; Sales Dasí, 'Continuaciones', 118.
} 
despite her gender, Bernal enjoyed relative financial, social, and intellectual independence as well as access to the products of an active print industry. Donatella Gagliardi's archival work has documented how Bernal moved in literate circles attached to Valladolid's chancery court. ${ }^{3}$ Bernal's first husband was a relator ('court reporter'), and her second was an escribano ('notary'). Both left property to Bernal in their wills, and upon the death of her second husband, Juan Torres de Gatos, Bernal earned income by renting rooms to chancery-connected boarders. Bernal's only child, Juana de Gatos, received an excellent education under the supervision of her mother and was reputed to know Latin. ${ }^{4}$ Though both Bernal and her daughter were involved in financial disputes, the inventory of Juana's goods indicates that they led fairly comfortable lives. ${ }^{5}$ Juana de Gatos's library inventory, taken in 1588 , notes an impressive sixty-one books from various genres. ${ }^{6}$ Juana's library inventory does not mention Amadis, but it does contain La Celestina, copies in print and manuscript of Cristalián, two books by Antonio de Guevara, several books of poetry, and a few volumes in Latin and Italian. ${ }^{7}$ Though the library inventory does not show which chivalric works Bernal read, her approach to citation and imitation in Cristalián reveals that she was a sophisticated consumer of Iberian chivalry. ${ }^{8}$ Valladolid printed many romances during Bernal's lifetime, including Tirant lo Blanch (1511, translated into Castilian) and Feliciano de Silva's Florisel de Niquea (1532); from Bernal's intertextual references, it seems likely that Bernal read widely in the genre. ${ }^{9}$

Though Bernal eventually succeeded at bringing Cristalián into print, the pressures that kept many women confined to the domestic sphere impacted its literary reputation. Bernal asked for permission to publish Cristalián de España in 1537 but did not secure it until $1545 .{ }^{10}$ Though Bernal revealed her

3 Gagliardi, Urdiendo ficciones, 77-88. A preliminary version of the research appears in Gagliardi's dissertation, “"Quid puellae cum armis?” Una aproximación a Doña Beatriz Bernal y a su Cristalián de España'.

4 Gagliardi, Urdiendo ficciones, 77.

5 Ibid., 83 .

6 Cátedra and Rojo Vega, Bibliotecas y lecturas de mujeres, 31.

7 Gagliardi, Urdiendo ficciones, 90-93.

8 Ortiz-Hernán Pupareli, 'Escritura femenina', 135-36.

9 Piera, 'Minerva', 74-76.

10 The 1545 edition of Cristalián, by Juan Villaquirán, may be found in libraries in London, Lisbon, Naples, Munich and Paris. The 1587 Alcalá edition is preserved in Barcelona, Madrid, Valencia, London, and Paris. An Italian translation of Cristalián appeared in $155^{8}$ and was reprinted in 16o8. In preparing this chapter, I consulted the 1545 (RES-Y2-251) and 1587 (RES G-Y2-24, MFILM RES G-Y2-24) editions of Cristalián at the Bibliothèque Nationale de France 
gender in the liminary material, she remained anonymous until 1587, when Juana de Gatos named her as the author to secure permission to print a new edition. ${ }^{11}$ Gatos cited dire financial circumstances as the impetus behind her desire to reprint her mother's work, rendering Bernal, if posthumously, Spain's first female professional writer. ${ }^{12}$ Although Cristalián was a modest success in the sixteenth century, accumulating a number of citations in other works as well as a 1558 Italian translation, literary historians through the twentieth century tended to dismiss it. Marcelino Menéndez y Pelayo writes that Cristalián de España only has merit because it was the work of a woman, and many other scholars appear to have agreed that it was, at best, a footnote in literary history. ${ }^{13}$

Though a handful of scholars have written about Bernal in recent years, interest continues to lag behind that in other early modern women writers. One concrete obstacle to the study of Bernal is the availability of her work to specialist and non-specialist readers. Jodi Growitz produced the first modern edition of Cristalián in 2014, covering only the first two books, and as of this writing, books three and four can only be accessed in modern edition through Sidney Park's 1981 dissertation. ${ }^{14}$ Neither the Growitz nor the Park edition provides a text of the full romance with a robust critical apparatus. Park's edition takes a modernizing approach, and Growitz's takes a paleographic approach, but neither makes the romance accessible to readers not already steeped in the genre. As a consequence, Bernal might well seem less modern, and perhaps less capable as a writer, to twenty-first-century readers than male authors of the period who have been edited differently. The intersection of gender and genre, moreover, appears to have discouraged many scholars from approaching Bernal at all. Chivalry began to fall out of fashion in the latter half of the sixteenth century in Spain, and Cristalián's length and proliferation of characters and subplots require significant investment on the part of readers. Though interest in Iberian chivalry has increased in recent decades, works thought of as minor, like Cristalián, are often assumed to be of low literary quality. Whitenack suggests that Bernal's

(Mitterand) in Paris. See Bernal, Cristalián de España, 1545; Gagliardi, Urdiendo ficciones, 136; Growitz, 'Introduction', 10.

11 Gagliardi, Urdiendo ficciones, 73 .

12 Ibid., 74-75.

13 Menéndez y Pelayo, Orígenes de la novela, 1: 294; Gagliardi, Urdiendo ficciones, 18.

14 For citations of Cristalián, I privilege Jodi Growitz's edition for Books I and II and use Sidney Park's dissertation edition for Books III and IV. When I cite Growitz's edition, I remove the angle brackets and hyphens used for paleographic transcription in order to facilitate reader comprehension. See Bernal, Cristalián de España, 2014; Park, 'Don Cristalián'. 
success at fitting in with her genre is part of her reception problem; for Whitenack, there is nothing particularly feminine about Bernal's writing, and Cristalián is relatively indistinct from other chivalric romances. ${ }^{15} \mathrm{It}$ is also possible to take the opposite view. Menéndez y Pelayo wrote that Cristalián is a labor femenina ('feminine labor'), by which he implies that it is too feminine and can therefore be dismissed as a curiosity. ${ }^{16}$

My view of Cristalián splits the difference between Whitenack and Menéndez y Pelayo's assessment of its gendered qualities. I agree with Whitenack that nothing about Bernal's diction, choice of genre, or overarching plot is essentially feminine, as in fact it has proved difficult for critics to identify 'women's writing' in any stable or satisfactory way. Hélène Cixous, exploring the term écriture féminine ('feminine writing'), argues for an expansive, abstract definition: 'Woman must write her self: must write about women and bring women to writing, from which they have been driven away as violently as from their bodies - for the same reasons, by the same law, with the same fatal goal. Woman must put herself into the text-as into the world and as into history-by her own movement. ${ }^{17}$ Cixous's formulation would account for a variety of ideological positions among women writers, potentially including those that support existing social norms in addition to flaunting them. Indeed, the feminine perspective Bernal encodes in her writing is often conformist. It is important not to read Bernal as a feminist avant la lettre; rather, she is first and foremost a writer of her century and her genre, if a somewhat unusual one. I follow Elaine Showalter in cautioning that women's writing should not be expected to be universal or uniform in content or purpose. ${ }^{18}$ Bernal, however, is clearly thinking through the problem of gender in her writing, albeit within the confines of existing chivalric motif and Golden Age perceptions of femininity.

Bernal pushes at the boundaries of chivalric femininity in subtle rather than overt ways, pondering the intersection of gender and genre as a reader and as an author. Cristalián sifts out, reiterates, and reconsiders many of the stories Iberian chivalry tells about women. Iberian chivalric narratives, especially Amadis, take a relatively egalitarian approach to women's literacy, allowing women to use reading and writing as a means of egress from the domestic sphere. For the chivalric woman, literacy offers an escape valve within an otherwise male-dominated social system. Bernal physically

Whitenack, 'Emphasis Added', 26.

Menéndez y Pelayo, Orígenes de la novela, 1: 264 .

Cixous, 'The Laugh of the Medusa', 875 .

Ibid.; Showalter, 'Feminist Criticism in the Wilderness', 185-86, 197. 
frees some of her women characters from the domestic sphere, but writing and reading continue in Cristalián to serve as proxies for action for two major female chivalric archetypes - the enchantress and the princess. ${ }^{19}$ However, Bernal issues more caution about women's literary practices than Montalvo did.

This chapter examines instances of reading and writing associated with women in Cristalián de España. These episodes depend heavily on intertextuality, displaying Bernal's own ingenuity as a reader of other works in her genre. Though Bernal's many references to literate women reveal an interest in women's lives and women's perspectives, these episodes do not advocate the subversion of masculine dominance in any categorical way. Rather, Bernal's ambivalence about her literate female characters emphasizes the risks as well as the rewards literacy poses to women of the Spanish Golden Age. Authority and power, moreover, are at issue in many of these episodes. Bernal appears to ponder whether women can exercise textual authority or whether, in contrast, the powers of text belong exclusively to men.

\section{Reading and Textual Authority}

Bernal's proemio ('prologue'), the most commented portion of Cristalián de España, establishes writing as a masculine activity women can usurp, using literary devices that both establish and diffuse feminine narrative authority. ${ }^{20}$ In the proemio, a fictionalized version of the author finds a manuscript in a crypt and, 'acuciosa de saber sus secretos (eager to know its secrets)', reads and translates it for a new public. ${ }^{21}$ Like many apocryphal manuscripts in the chivalric tradition, Bernal's imaginary book is ancient and foreign:

Hallé que estava escripto en nuestro comun lenguaje, de letra tan antigua, que ni parescia Española, ni Araviga, ni Griega: Pero toda via cresciendo mi desseo, y abraçandome con un poco de trabajo, vi en el muy diversas cosas escriptas, de las quales, como pude, traduxe y saque esta historia, pareciendome de mas subtil estilo que ninguna otra cosa

19 The female characters who escape physical confinement include Minerva, the Amazon-like warrior, and Amplamira, the traveling British princess.

20 Marín Pina, 'Beatriz Bernal', 282.

Bernal, Cristalián de España, 2014, 891. 
(I found that it was written in our common language, but in such antique handwriting that it did not appear to be Spanish, Arabic, or Greek. But my desire increased even so, and by embracing a bit of work, I was able to see in it many diverse things written, from which, as I could, I translated and brought out this story, which seemed to me of more subtle style than any other $)^{22}$

The device of the apocryphal manuscript gives Bernal's romance an external provenance, if a transparently fictional one, and provides an excuse for literary activity that goes beyond what is customary for her gender. This moment is emblematic of how Bernal treats feminine authority and literary activity more generally. She hides it behind a masculine façade, mixing subversion with conformity.

Though Bernal nominally pays respect to masculine authority, represented by the male corpse from which she takes the book, the proemio also stakes a claim for women in public life. Gagliardi observes that the author-character finds her manuscript in the only public space to which women had access, the church. ${ }^{23}$ Yet the author-figure's actions are less than devout; indeed, Bernal describes the taking of the manuscript as sacrilegio. Gagliardi reads the episode as an echo of the story of Eve, and Montserrat Piera views the author-figure's defiance and curiosity in terms of Eve and Pandora. ${ }^{24}$ The proemio represents feminine reading as a secret and dangerous act, but also, as Piera points out, a successful one. ${ }^{25}$ I would add to these prior readings of the episode that Bernal's short description of the manuscript find is rich in the diction of emotion. For the author-figure, the taking, reading, and translating of the manuscript is akin to an act of lust. Bernal describes her avatar as acuciosa ('moved by violent desire') when she encounters the manuscript, and 'translating' it appears to evoke even stronger feeling, as the words deseo ('desire') and abraçandome ('embracing') indicate. ${ }^{26}$ Bernal's proemio thus evinces the same association among women's writing, emotion, and interiority found in Amadis de Gaula.

The proemio, in fact, shares more with Bernal's chivalric sources than an association between writing and the emotions. The apocryphal or found manuscript is a habitual trope for Iberian romance, though Bernal uses 
it a bit differently from any other writer. Bernal might have known the motif from Garci Rodríguez de Montalvo's Amadís de Gaula or Las sergas de Esplandián (1505), Gonzalo Fernández de Oviedo's Claribalte (1519), Juan Díaz's Lisuarte de Grecia (1526), Feliciano de Silva's Amadís de Grecia (1530), or a number of other texts. ${ }^{27}$ Amadís is probably the immediate source, as like Bernal, Montalvo describes the ancient manuscript as coming from a grave, in his case a tumba found under a hermitage in Constantinople, though he describes this finding as an archeological discovery rather than an instance of grave-robbing. ${ }^{28}$

The trope of the found manuscript allows romance authors to blur the line between history and fiction and praise the products of their own invention while seeming to obey the authority of the past. Chivalric authors may also use a fictional encounter with a fictional manuscript to represent their relationship to their own real sources. Montalvo did not buy an ancient Greek manuscript from a Hungarian merchant, as he says in his prologue, but he did work from an existing medieval Amadis that had in turn drawn, at some point in its past, on the prose Lancelot. Thus, the two-step voyage Montalvo imagines for the manuscript, first from the Greek tomb into the hands of the Hungarian merchant, and then from the merchant to Montalvo, reflects a real two-step process of literary transformation. Montalvo, however, does not use the language of desire to present his false manuscript, speaking only of trabajo ('work'). ${ }^{29}$ Other writers used the apocryphal manuscript trope to pretend that sources like Montalvo's had existed, locating authority as something ancient, past, and unquestionable. In all of its forms, the apocryphal manuscript trope dissembles the process of intertextuality, reinventing the relationship between source text and target text to undermine the authority of the real or alleged source even while paying lip service to it..$^{30}$ When sources are fictional, or when their provenance is obscure, the only author-figure left is the one who brought the work into print.

Bernal uses the found manuscript motif to stake a claim in a genre dominated by men. The secretive taking of the text from the crypt distinguishes Bernal from her intertexts; most authors do not represent their acquisition of

27 Cuesta Torre, 'Combates interrumpidos', 564.

28 Rodríguez de Montalvo, Amadís de Gaula, I: 225.

29 Ibid.

30 By 'source text', I mean a prior text on which a new author draws; by 'target text', I mean the final result that shows the evidence of borrowing from the source. I adapt these terms from Susan Bassnett's work in translation studies, and I find that they apply to the case of intertextual borrowing as well as to translation. See Bassnett, Translation Studies, 81. 
the manuscript, whether discovered or bought, as criminal or sacrilegious. Bernal, moreover, will give hints later in the text about the identity of the corpse. Bernal's narrator tells us that the wise giant Doroteo wrote the romance; the body in the tomb is probably his. If indeed the corpse is a character from Cristalián, Bernal has stolen only from herself. Though the literary authority appears to be masculine, his gender is only a mask. For me, the taking of the manuscript in the proemio is indicative of how women usurp men in the narrative of Cristalián, both where literacy is concerned and otherwise. They appropriate tools and texts from men and adapt them for women, but the act of doing so is dangerous. The connection to emotion in the episode speaks to the high stakes in Cristalián of undertaking literary activity while female. Literary practices remain transgressive throughout Cristalián, and Bernal is as careful about them as she is about her found manuscript trope. Bernal's female characters use books for purposes good and evil, and though women express their thoughts and feelings in letters, their expressions are more guarded than those of their intertextual models. Literate women, moreover, are often solitary or despised by other characters, condemned to live at the margins of their society.

The plot of Cristalián de España appears, at the superficial level, to be just as male-oriented as that of other romances, but as with the manuscript in the tomb, all is not as it seems. The romance begins with the titular character's father, Lindedel, presenting his boyhood, early adventures, marriage to Cristalina, and the birth of their sons, Cristalián and Luzescanio. In subsequent episodes, Lindedel's sons grow up, undertake quests, and meet their destined brides, Penamundi and Bellaestela, respectively. Women play roles more prominent than usual in chivalric romance throughout the book. Referencing the use of the word sutil in Bernal's proemio, Judith Whitenack terms Bernal's emphasis on women a 'subtle but persistent subtext' ${ }^{31}$ For Montserrat Piera, Bernal's active female characters, particularly the warrior Minerva, undermine the genre's usual argument about masculinity. ${ }^{32}$ Growitz refers to Bernal's romance as a 'chivalric microcosm that [...] defies gender restrictions by tipping the scales of control'.33 Cristalián's first adventure is to rescue the mother for whom he was named, and all the men and women of the family benefit from the patronage of Membrina, an enchantress in the tradition of the Lady of the Lake. A second enchantress, Celina, who protagonizes a gender-reversed Sleeping Beauty plot, aids 
Cristalián's younger brother, Luzescanio, in his adventures. Each of the younger knights has a female associate with whom he experiences no erotic tension. The Amazon-like Minerva accompanies Cristalián on many quests, and Luzescanio encounters British princess Amplamira during a series of maritime adventures. Contrary to the usual proceeding in Iberian romance, both Minerva and Amplamira split off from their male compatriots and protagonize self-contained episodes. ${ }^{34}$ The romance's entire cast gathers at the end of the book for Cristalián and Penamundi's wedding, where a magical whirlwind sweeps them away to new adventures that remain forever untold, as neither Bernal nor anyone else wrote a sequel. With her whirlwind, Bernal defers the heterosexual couplings that end most romances. Such marriages often condemn female characters to submission to their husbands and cause them to lose the conditional subjectivity they had during their youth.

Cristalián evokes reading and writing through landscape, magic, books, and letters, and each of these devices grants practitioners power and authority. The primary expression of magic in Cristalián is the epigraph, which allows magical practitioners to inscribe their desires and perspectives quite literally in the landscape. They use words to create instructions and traps for seekers, and the marvels they craft recall Amadis's Ínsola Firme ('Firm Isle') and the Lancelot's Douloureuse Garde ('Dolorous Gard'). The origin of this type of magic is not innate ability but book knowledge. To produce or interpret landscape marvels, magical practitioners seek power in the written word. The enchantresses Membrina and Celina own personal libraries, as does the evil enchantress Drumelia. Knights must also participate in the game of reading. The fairy doncella del gavilán ('lady with the sparrowhawk') sets a series of tasks for Cristalián that require reading skill and knowledge of languages. Unlike in Amadís de Gaula, men cannot simply hack and slash their way through chivalric challenges; they have to know the 'feminine' skill of manipulating the written word. More mundane letters, meanwhile, allow characters to communicate and make decisions, transmitting feelings or information. Two of the letters cited in the romance come from women, the first from Cristalián's beloved Penamundi, and the second from a minor character, Libida, queen of Armenia. Both of these letters appear imbedded in motifs of courtly love, and they play with the power the lady holds - or appears to hold-over her knight. The authority women wield through text, however, is always conditional. Though Cristalián contains more authoritative literate women than Amadís de Gaula, female characters pay a greater 
price for their literary freedoms than their models, indicating that text, though powerful, is not powerful enough to upend the social order.

\section{Good Enchantresses}

Most of the literate women in Cristalián are enchantresses, and Montalvo's Urganda la Desconocida appears to have been a potent influence on Bernal's use of this character archetype. As the previous chapter discussed, in Amadís de Gaula, Urganda writes letters and uses books of magic to cast spells in the service of the ruling families of Britain and Gaul. In Montalvo's sequel, Las sergas de Esplandián, Urganda also serves as a literary patroness, offering the author-figure an apocryphal manuscript..$^{35}$ Bernal's enchantresses, like Urganda, practice a textual variety of magic, though Bernal emphasizes the reading of books over the writing of letters. The major difference from the world of Amadis is the sheer number of enchanters and enchantresses Bernal imagines; each main character interacts with multiple magicians, both male and female. Bernal's enchantresses can be either good or evil, and this chapter will deal with them separately, as their literary practices differ.

Both types of enchantresses model some of the practices of feminine authorship Bernal hinted at in the proemio. Judith Whitenack points out that Bernal always refers to enchantresses as sabias ('wise women') rather than magas ('magicians'), which indicates that reading and study are the source of their power. ${ }^{36}$ Good enchantresses study books, finding prophecies and guidance within. Evil enchantresses read out loud from books, using them to cast offensive spells. Whitenack observes that in Cristalián, magic is not considered evil a priori: 'We find none of the preaching against enchantments and magic characteristic of several of the earlier and more strictly religious romances, most notably Florisando'.37 Bernal, however, distinguishes her enchantresses by their intentions. Good sabias use their knowledge to help others, while evil sabias use magic to wound or take revenge. Both types, however, prove an awkward fit within the dynastic families that dominate romance plots. Most of Bernal's magical practitioners are represented as elderly and unmarried. It is unclear in Cristalián whether advanced learning can be compatible, even in exceptional cases, with the 
expectation of marriage and motherhood that structures the lives of Iberian chivalric romance's most privileged women..$^{8}$

Yet Bernal's sabias are not immune to family concerns, and they use their magic to create families of choice, composed of themselves as mother figures and their protégés as stand-ins for children. These motherly and grandmotherly personas stand in contrast to the magical seductresses of the Italian tradition. They recall French and Iberian enchantresses in their associations with ruling families and in their substitution for mothers who are lost or missing. In Amadís, as Chapter One described, instances of maternity were often tied to interpolated texts, and in Cristalián, surrogate mothers interact with texts. Membrina, the first sorceress to appear in Bernal's romance, recalls Urganda in both her literacy and her sponsorship of one particular chivalric dynasty. She also echoes Urganda's Arthurian source, the prose Lancelot's Lady of the Lake, as well as the Muslim enchantress Melía of Las sergas de Esplandián. ${ }^{39}$ Like Urganda la Desconocida, Membrina lives on a hidden island, specializes in prophecy, travels about in a magical boat, and transforms her appearance through optical illusion. Membrina owns an extensive magical library, as does Montalvo's Melía, and she echoes the Lady of the Lake in her provisions for the early education of Cristalián's father, Lindedel.

Membrina's presence in the text is authorial in addition to maternal, and her practice of magic mirrors the processes that allow an author to translate or imitate a source work. Membrina, however, takes greater social risks than the author-figure of the proemio. Membrina explicitly desires independence from men: 'Fue tanto el su saber que jamas quiso tomar marido porque nadie tuuiesse mando ni señorio sobre ella (Such was her knowledge that she always refused to marry so that no one would have dominion or power over her) ${ }^{\prime}{ }^{40}$ For Montserrat Piera, Membrina's resistance to marriage speaks to Bernal's perception of the demands of family life as incompatible with a life of study, and for Gagliardi, Membrina rejects men out of pride and, perhaps, out of wisdom..$^{41}$ As a determinedly single magician, Membrina is an update on Urganda, who has a lover in Amadís de Gaula and marries

\footnotetext{
$3^{8}$ Gagliardi, Urdiendo ficciones, 204-205.

39 In Las sergas de Esplandián, Melía is a Muslim enchantress who has exiled herself to a cave hidden in a savage landscape. Though her long hair and animal skin clothing indicate a degree of savagery, inside the cave Melía preserves a marvelous library. See Rodríguez de Montalvo, Las sergas de Esplandián, $55^{8}$.

40 Bernal, Cristalián de España, 2014, 64.

41 Piera, 'Minerva', 82; Gagliardi, Urdiendo ficciones, 204-205.
} 
the magician Alquife in one of the sequels. While Urganda surrenders some of her autonomy when she marries, Membrina refuses to do so.

Though Membrina does not have children of her own, her sponsorship of Lindedel allows her to use her literary practices to influence the next generation. In order to plan Lindedel's first quest, Membrina goes to her library to consult a book by the apocryphal female historian Nicóstrata. Bernal might have read about Nicóstrata in Giovanni Boccaccio's De Mulieribus Claris (The Famous Women, 1374), Christine de Pizan's La Cité des Dames (City of Ladies, 1405), Álvaro de Luna's Libro de las claras evirtuosas mugeres (The Book of Famous and Virtuous Women, 1446), or Antonio de Guevara's Relox de príncipes (The Dial of Princes, 1529), all of which describe the figure as an emblem of feminine learning. Gagliardi and Marín Pina agree that Guevara is Bernal's immediate source, as she follows him in characterizing Nicóstrata as a historian of the Trojan War. ${ }^{42}$ In Bernal's treatment of the motif, Nicóstrata's history reveals the location of Priam's treasure and tells how its ghostly guardian Troilus may be defeated. Urganda, the Lady of the Lake, and Membrina all choose their protégés' initiatory quests, but only Membrina draws on explicitly literary knowledge in order to do so. Membrina's choice of text suggests that Bernal imagines an alternate history written by women that contradicts dominant versions of history written by men.

Nicóstrata, purportedly an eyewitness to events at Troy, writes about the actions of Cassandra, daughter of Priam, crediting her with the scheme to enchant her slain brother and preserve the family wealth. ${ }^{43}$ Bernal also writes about another of Priam's children in the passage, Cassandra's lovely sister Polyxena, implying that the Trojan women are just as important to history as the men she mentions, Achilles and Hector. Marín Pina points out that Bernal represents Cassandra as a sabia comparable to those depicted in Cristalián, just as Amadis sequel writer Feliciano de Silva did with Medea. ${ }^{44}$ Thanks to Cassandra's arts, Troilus awaits a worthy champion to release him from living death. Thanks to a chain of three wise women-Cassandra, Nicóstrata, and Membrina-Lindedel has the opportunity to inherit the glories of the past. This tripartite cooperative of female scholars recasts the generational argument of Iberian romance in which sons replace their

42 Bernal, Cristalián de España, 2014, 64; Gagliardi, Urdiendo ficciones, 203; Marín Pina, 'Beatriz Bernal', 286.

43 Bernal, Cristalián de España, 2014, 64.

44 Marín Pina also points out that this episode owes to the Crónica troyana. See Marín Pina, 'Beatriz Bernal', 291. 
fathers. The knight who participates in this adventure is incidental, and the real generational transfer passes from sabia to sabia. The episode is important for Lindedel's entire family, as Priam's treasure and the fame Lindedel earns as a champion allow him to rise from obscurity and court the princess of Constantinople. Membrina, without whom the quest would not have occurred, is thus the founder of a new chivalric dynasty.

Celina, a younger sabia, plays a similar role in the life of Lindedel's son Luzescanio. She identifies Luzescanio's initiatory quest in another search through the archives, and like Membrina, she resists marriage in order to preserve her independence. Celina, however, is also the ruler of her kingdom, as her father has died with no other heir. She thus cannot choose Membrina's path of determined independence. Though she acquiesces when her advisors implore her to take a husband, she rejects a political match, insisting instead on choosing her own marriage partner. ${ }^{45}$ The details of Celina's marriage plot suggest a possible intertext for the episode, the twelfth-century French Partonopeus de Blois, which was loosely translated in Castilian in 1497 as El conde Partinuplés and enjoyed considerable popularity in the Iberian Peninsula. ${ }^{6}$ This short romance offers a fable of women's scholary achievement along with a story of lust, deception, and marriage. The protagonist, a young fairy named Melior who is also the empress of Constantinople, seeks a worthy husband who will obey her commands. At a young age, Melior displays an extraordinary talent for book learning and magical arts and enough wisdom to know that she should not let her political advisors influence her choice of husband. She identifies a French prince as her ideal partner, secretly brings him to her kingdom at Constantinople, and visits him only at night. The prince must swear never to look upon his future bride, or else she will reject him. This reverse Cupid and Psyche plot ends, unfortunately, in Melior's humiliation. Partinuplés lights a candle, breaking his word, and Melior sentences him to death. Luckily for Partinuplés, other characters conspire to secure his pardon. Despite her book learning and her will to assert her own point of view, Melior's fate is to be twice ignored: first, when Partinuplés forgets his promise; and second, when her sister and advisors save him from punishment. Like Cristalián itself, the Partonopeus romances suggest that scholarly women may have only conditional freedom and that the power they gain through knowledge has a significant opportunity cost. Partonopeus was also, via the Castilian translation, the source for Ana Caro's play El conde Partinuplés. This romance 
about the impossibility of reconciling feminine learning with the demands of marriage was compelling enough to inspire at least two women in early modern Spain to create their own versions.

Celina's story adapts the nature of Melior's learning while leaving behind the French romance's most notorious feature, the 'invisible mistress' motif that featured frank depictions of sexuality. ${ }^{47}$ Perhaps ironically, by removing the humorous scenes of adolescent sexual exploration that made both Partonopeus and its translation scandalous, Bernal also ensures a happier fate for Celina. Bernal's episode resembles the language of the translated Partinuplés in its description of Celina's education and search for an appropriate husband. From an early age, Bernal's Celina shows aptitude for learning: 'Esta princesa fue muy afficionada a aprender la[s] artes y como el rey barciano su padre la amasse tanto hizo venir a su reyno grandes maestros para que su hija fuesse enseñada. Esta fermosa princesa aprendio tanto que passo en su saber a todos los maestros (This princess was very fond of learning the arts, and as King Barciano her father loved her so much, he brought great masters to his kingdom so that his daughter could be instructed. This beautiful princess learned so much that she surpassed all the masters in her knowledge)'. ${ }^{8}$ Both Celina and Melior of the translated romance are child prodigies who quickly outpace their tutors, and each learns unspecified 'arts'. The 'arts' in question are likely magical arts, but they could also be the liberal arts. In the French version of the romance, Melior specifies that she has learned sorcery, the seven liberal arts, and medicine, though this extended description did not make it into the 1497 translation. ${ }^{49}$ In both Bernal and the translated Partinuplés, the learned princess's father dies, leaving the kingdom in her hands at a young age. The princess's advisors, with the implied consent of the people, attempt to force her to marry. The Melior character of the Castilian translation stalls her tutors by sending letters all over the world looking for a good match. Celina buys time by considering her problem in the library:

La reyna estuuo quinze dias que jamas hizo sino mirar y reboluer en sus libros \& a la fin ella supo por sus artes que en la deuisa del valle fermoso estaua encantado vn cauallero llamado Sonabal de fenusa rey de la diserta a marauilla muy preciado cauallero: ella tuuo mucha voluntad de lo auer por marido: pero no sabia como lo librar de aquel encantamento: 
y tornando a reboluer sus libros hallo que no podia ser libre sino fuesse por la mano del segundo hijo del valiente \& muy esforçado emperador lindedel de trapisonda.

(The queen spent fifteen days doing nothing but looking at and leafing through her books, and at the end she discovered by her arts that in the kingdom of Valle Fermoso there was an enchanted knight named Sonabal de Fenusa, King of Diserta, who was marvelously well regarded. She had a great desire to take him for her husband, but she did not know how to free him from that enchantment. Going back to her books, she found that he could not be freed except by the hand of the second son of the most valiant and brave emperor Lindedel of Trebizond.) $)^{50}$

Like Membrina, Celina uses her research skill to identify a worthy quest, but this adventure makes a more personal reflection on women's literary talents than the treasure-dive in the tomb of Troilus. The description emphasizes Celina's desire ('tuvo mucha voluntad') without suggesting concupiscence, and it allows an enchantress to marry, seemingly without disturbing either her study or her rule. Celina is unusual among the sabias of Cristalián in that she does not appear to give up her literary study, her agency, or her chance at forming a family, at least not during the episode as Bernal presents it to readers.

Celina, moreover, is one of the few female characters in Iberian romance to rescue a male character. The King of Diserta was enchanted into a seeming death many years ago by Darsia the enchantress, now a shriveled, bitter old woman. Darsia had wished to marry him, and he refused. He was unable to outmaneuver her magic, and she buried his still-living body in a glass coffin surrounded by magical guardians. Celina and her future husband are both prisoners constrained by the threat of an unwelcome marriage, and the fairy tale-like resolution of the episode frees both characters from submitting to a sexual partner not of their choosing. Once he regains consciousness, the King of Diserta falls in love with Celina without any prompting, magical or otherwise-he is simply impressed by her beauty. Celina's research earns her a grateful and good-natured partner, though not a particularly capable fighter. Perhaps by assigning her one of the book's most helpless knights, Bernal means to suggest that the enchantress will retain a measure of independence. Indeed, Celina's plan works out much better than Melior's gambit from the source romance, which compromised the latter's chastity. What is more, Bernal uses this episode to rewrite Membrina's greatest sin, 
stealing the infant Lindedel from his mother, in a positive way. Celina knows that the young Luzescanio must help her, but she does not abduct him to make sure he is under her control. He comes to the adventure on his own, and Celina assists him without intruding on his free will.

\section{Evil Enchantresses}

Membrina and Celina both use their powers for good, and Celina is able to reconcile the conflicting requirements of marriage, politics, and the pursuit of knowledge. However, in Bernal's romance, not all women who practice literary magic do so with good intentions. Indeed, Bernal expresses her greatest degree of ambivalence about women's learning and its consequences through the corrupt reading practices of evil sabias. Evil magic poses a greater threat to gender norms than good magic, as it has an offensive, public orientation instead of a private, knowledge-based one. It also validates fears about the consequences of women's education. The evil enchantresses fall prey to anger and jealousy, and their arcane knowledge allows them to attack others. Bernal's magical practitioners tend to be less sexualized than the seductive sorceresses of Italian chivalry, including Ariosto's Alcina and Tasso's Armida, but they still reflect a negative view of feminine learning. Their targets are often other women, and in harming the young, they seek to prevent the generational transfer of power from woman to woman and sabia to sabia.

Danalia, the first of the evil enchantresses to surface in Cristalián, is an elderly single woman of considerable power who crafts a large-scale enchantment to take revenge on a younger woman. Though Danalia, like Membrina and Celina, refused to marry so that she could pursue a life of study, she has a nephew for whom she serves as patroness. This nephew dies of grief when Penamundi, the princess of Persia, rejects him. In response, Danalia drowns Persia's capital city, Larenta, in a magical lake and situates a dragon as its guardian. Like other marvels in the chivalric tradition, beginning with the prose Lancelot's Douloureuse Garde and including Amadis's Ínsola Firme, the ruined city of Larenta contains epigraphs that tell seekers how to solve its puzzles. Bernal favors such magical epigraphs, using them to an even greater extent at the arches of flame that are crafted by the male enchanter Dioneo.

Although landscape epigraphs are not the exclusive creation of female magicians, they imply that the business of enchanting, for women as well as men, is a literary one. Amadís and Las sergas de Esplandián contain 
precedents for landscape writing by a female enchanter. In those romances, the luckless, unattractive doncella encantadora ('enchanting damsel' or 'damsel enchantress'), left epigraphs leading to her treasure after she committed suicide..$^{51}$ For adventurers, these epigraphs offer a test of literacy; knights must read the instructions to earn a reward. Such magical epigraphs are curiously self-defeating, as the downfall of the enchanter often occurs as soon as characters read and follow the instructions. Even good enchantments like those at Ínsola Firme can be brought to an end by successful reading, interpretation, and completion of the assigned task. For female enchanters, moreover, there is a gendered dimension to the threat of being read. A female magician may express her rage and grief using her literacy, but because men share the use of the tool, her attempt to punish her enemies fails. For Bernal's female enchanters, writing serves as a proxy for direct action, but as with the female letter writers and enchanters of Amadis, using writing in this way does not guarantee the accomplishment of one's goals.

Danalia's epigraphs at Larenta explain the relationships among magical objects and guide knights through a maze of challenges. The words draw victims into the marvel, where they become trapped if they cannot meet the enchantment's conditions. The first epigraph, which appears graven on a monument by the lake, explains that the knight who grasps the enchanted sword suspended over the water will be granted entry to the castle below. This initial challenge recalls the Arthurian motif of the sword in the stone:

Junto al lago estaua vn padron en cima del qual auia vna grande ymagen de Cobre y tenia en sus manos vn letrero que dezia assi: aquel bien auenturado cauallero que la fermosa espada en su poder vuiere sea cierto que dara Cima a la grande auentura de larenta: y la su alta caualleria passara a todos quantos oy en el mundo son.

(By the lake there was a column upon which there was a large statue in copper which had in its hands a sign that read: the fortunate knight who will have this beautiful sword in his power will surely complete the great adventure of Larenta: and his great chivalric prowess will surpass that of all who are in the world today. $)^{52}$

The enchantment suspends those who fail next to a copper column with an inscription that reveals their names. Most who try the marvel, including the girl warrior Minerva, meet this ignominious fate. The self-engraving 
plaque works the same way the padrones or columns do at Amadis's Ínsola Firme, and both are made of copper, which suggests that Bernal has Amadis in mind as an intertext for the episode. The fact that the marvel at Larenta is reserved for the best knight in the world echoes Ínsola Firme's test of knightly prowess at the Cámara Defendida ('Forbidden Chamber'), which compels men to fight invisible opponents and emblazons their names upon shields where they yield. ${ }^{3}$ One major difference here is that Bernal allows both men and women to try the test of military might; even in its small details, Bernal's world is more egalitarian than that of Amadis.

Once Cristalián grasps the sword, he enters the castle, where another epigraph guides him toward the dragon: 'Si tu cauallero venturoso que la rica espada ganaste esta grande \& muy espantosa auentura quisieres acabar sepas que la tu entrada a de ser por aqui (If you, fortunate knight who won the sword, wish to complete this great and terrifying adventure, you should know that the entry is through here)' ${ }^{5} 4$ This magical signpost resembles the written clues Lancelot follows inside Douloureuse Garde after defeating the military challenges in the courtyard. ${ }^{55}$ Habituated readers of chivalry might expect a battle with the dragon, but all Cristalián must do is read it. The dragon opens its mouth, and an emerald lizard emerges, inscribed with a second message in gold letters telling Cristalián to walk down the dragon's throat..$^{6}$ Cristalián can read the Latin script because he spent the first eleven years of his life studying 'todas las lenguas del mundo (all the languages of the world)'. 57 Even though Cristalián dedicates little of his adult life to scholarship, he had an advantageous education as a child that outmatches even Celina's. Perhaps Bernal means to indicate that even though her world contains many literate women, men still have easier access to literary culture. There is a sense in this marvel that Cristalián beats Danalia at her own game, which might be understood as the interpretation of arcane language and symbols. Had Cristalián not been able to read Latin, he might have killed the dragon and lost his chance to free Penamundi. The linguistic ability needed to complete this marvel points back to the moment in the proemio when the author-figure 'translated' an apocryphal manuscript; Bernal appears to have a particular appreciation for language skill.

Bernal, Cristalián de España, 2014, I: 377.

55 Corley, Lancelot of the Lake, 119; Kennedy, Lancelot and the Grail, 25.

56 Bernal, Cristalián de España, 2014, I: 378.

57 Ibid., I: 190-91. 
Once inside the dragon's throat, Cristalián finds himself in a field, where he battles a beast named Babilonica. The monster is a relatively conventional two-headed 'hechura del Diablo (work of the devil)', and Bernal does not develop the battle with it in detail. ${ }^{8}$ The next challenge, however, shows more authorial care and introduces the trope of symbolic reading. A series of winsome damsels dressed in symbolic colors present themselves, each holding an apple that matches the color of her dress in a likely reference to temptation in the Garden of Eden. ${ }^{59}$ Bernal specifies the meaning of each damsel's color: green is for hope (esperanza), brown for struggle (trabajo), blue for jealousy (celos), yellow for hopelessness (desesperación), red for happiness (alegría). These damsels represent the emotions Cristalián has experienced on his journey toward Penamundi, but they also offer an additional test of reading: Cristalián must choose the real Penamundi from the parade of illusions. The princess, the most beautiful woman in the world, is dressed in the least beautiful color, black for sadness (tristura). Danalia has frozen her in a posture of mourning for the fallen nephew. The color black represents not just Penamundi's sadness at being trapped, or her regret at the inadvertent role she played in a man's death, but the grief that drove Danalia to create the marvel. Danalia exteriorizes her own emotion by imposing it visually on Penamundi.

The colorful damsels sequence is one of many instances in Cristalián that require the reading of symbols. There is no antecedent for this motif in Amadís de Gaula, but Feliciano de Silva's Amadís de Grecia (1530) predates Cristalián de España and contains a similar set of allegorical women. In an interlude in which Silva pays homage to his wife, Gracia Fe, two symbolic damsels, Esperanza and Desesperación, accompany the author-figure. These are also the names of Bernal's green and yellow ladies. ${ }^{60}$ Another reference point for the episode can be found in Tirant lo Blanch. When Tirant first encounters Princess Carmesina, she is clad in black garments and lying on a black bed, mourning for her brother. ${ }^{61}$ Her pose is similar to that of the enchanted Penamundi. Danalia's marvel thus has an intertextual complexity that shows off Bernal's own skill at combinatory, creative reading. This sabia's magic, however, comes to nothing because a man can read and understand it. Cristalián, moreover,

$5^{8}$ Ibid., 382 .

59 Ibid., 383-88.

6 o Silva, Choronica del muy valiente y esforçado principe y cauallero de la ardiente espada Amadis de Grecia, 94v.

61 Martorell and de Galba, Tirant Lo Blanc, 188. 
has the power to undo an old woman's aggression against a younger, weaker woman. Danalia's ire must have been based at least in part on generational resentment. Penamundi is her opposite in age and social status, and she is in many ways more conventional than the enchantress. Perhaps the defeat of Danalia is also Bernal's way of punishing — or cautioning-exceptional women.

Cristalián's most whimsical adventure, the defeat of the evil fairies of the Hondos Valles ('Deep Valleys'), also involves a generational conflict among women, this time among a family of fairy enchantresses. Cristalián meets an enigmatic young fairy, the doncella del gavilán ('lady with the sparrowhawk') on the road and agrees to help her defeat her seven aunts. These aunts, jealous of the young woman's beauty, kidnapped her seven years ago, and she has been serving as apprentice to the youngest. The seven aging hadas have a favorite spell, the transformation of humans into animals, which ranks third behind prophecy and architectural enchantments in frequency of magic types in Cristalián. According to the apprentice, the hadas are able to work their magic 'por su gran saber (because of their great knowledge'), implying that book learning plays a role in their spellcasting. ${ }^{62}$ In each of the seven fairies' personal homesteads, Cristalián meets characters who have been trapped by the evil women, usually through animal metamorphosis. The first fairy sends man-sized fish (her transformed relatives) to fight him ineffectually with swords, and another fairy has transformed a pair of star-crossed lovers into talking deer. More interesting for the purposes of this book, however, is the test of reading comprehension Cristalián faces at the home of the last fairy. For the final test, the doncella del gavilán herself, disguised with a veil, offers Cristalián a richly decorated book:

Parescio ante el vna Donzella con vn antifaz en el rostro: y ante el cauallero del leon puso vna rica Mesa: y puesta que fue la cubrio de vn paño de oro: y encima del puso vn libro todo guarnido de piedras y perlas de de mucho valor: la donzella le abrio y estaua todo escripto con letras de oro (There appeared before him a damsel with a veil over her face. Before the Knight of the Lion she placed a rich table, which she covered with a golden cloth. On top she placed a book decorated with precious stones and pearls. The damsel opened it for him, and he saw that it was written in letters of gold $)^{63}$ 
The fairy damsel here plays the role of librarian, literary patroness, or muse. The book appears to belong to her, as it is she who presents and handles it. The jewels, pearls, and gold indicate that the book is an item of value, perhaps even magical in some way. Considering the setting, it could even be the volume the seventh hada used to teach her niece magic.

The test that involves this book has metafictional overtones. The damsel explains that illusions will taunt Cristalián, and that he must keep reading despite them: 'Si a qual quiera destas siete cosas por ventura tu alçasses la cabeça dexando de leer en este Libro que ante ti tienes: luego los tus Dias seran fenescidos (If by chance you raise your head on account of any of these seven things, ceasing to read the book that you have before you, your days will then be finished), ${ }^{64}$ Cristalián must trust in the word of a woman as well as the words on the page. The distractions include a series of chivalric motifs: war, violence against a woman, water, fire, arrows, monsters, and a beautiful damsel asking a favor. They index the masculine business of knighthood, and dealing with these threats would be much more ordinary for a knight than either reading a book or serving an enchantress. The test possibly speaks to the powers of literary illusion, or to the dangers of novelistic distraction. The damsel controls the literary activity: she knows what is in the book and what the distractions will contain. Cristalián must remain passive throughout the episode, even when the chivalric code of conduct would demand action. Even as a reader he is passive; the text does not reveal what the book says by having Cristalián read aloud. In contrast to Danalia's enchantments, where Cristalián's education outmatched the enchantress's arts and showed him how to take action, here a man engages in a relationship to literature that is servile at best. This test, moreover, was not a strictly necessary part of the quest to liberate the Hondos Valles. At its conclusion, the doncella del gavilán reveals that the last fairy was already on her deathbed. The doncella del gavilán, who had heretofore seemed to be a good enchantress, seems to have improvised the final test for her own reasons. Perhaps she uses the magical book to show Cristalián that she is no longer a victim of her aunts, but if that were the case, why would she threaten Cristalián's life? Perhaps Bernal means to suggest that the young damsel will someday outmatch her aunts as an evil sorceress. Cristalián has freed the young fairy from her duties, leaving her free to indulge in the corruption that appears to overtake most enchantresses as they age.

A third evil, elderly enchantress, the sabia Drumelia, uses books as weapons even more directly than the doncella del gavilán. Drumelia, like 
Membrina, predicts the future based on what she reads. She learns from her books that Cristalián's family will cause her pain, and she seeks revenge against them in advance. Drumelia's library, however, is quite different from Membrina's. In order to work her power, she uses five libricos ('small books') from which she reads spells aloud. This is the only instance in Cristalián that reads like a modern depiction of wizardry; when Drumelia chants, architectural enchantments and animal transformations occur. The fact that Drumelia must read out loud from the books to cast her spells rather than simply learning from them hints that the books have intrinsic powers. They are perhaps even inherently evil and thus the source of Drumelia's corruption. Roger Chartier comments that medieval and early modern authors often describe the use of magical books in the language of diabolical possession'. ${ }^{65}$ In this case, Drumelia possesses the books rather than the other way around, but perhaps they have seductive qualities that have drawn her in.

The reader first encounters Drumelia's magic when Candebia, a lovely young huntress, arrives at court with a sword imbedded in her skull. Candebia declares that the sabia Drumelia has punished her this way for indulging in the vicio ('vice') of hunting, and that only the best knight in the world can save her life. This episode thus features the punishment of a younger woman by an older woman on account of her supposed shortcomings. Candebia is a sympathetic character, and she entices several members of Cristalián's family to follow her out into the wilderness. On the road, an elderly damsel, who will turn out to be Drumelia, appears and offers the party delicious-looking fruit. Upon eating it, they turn into birds.

The whole family, however, has not yet undergone avian metamorphosis, and in order to trap the stragglers, Drumelia takes her magic books on the road:

Dize la hystoria que como aquella reyna \& principe \& infanta y toda su compañia fueron presos y encantados que lugo ella puso por obra su dañado pensamiento: \& tomando cinco libricos pequeños sola en su palaren no lleuando en su compañia sino vn escudero tomo su camino para el imperio de trapisonda

(The story says that once the queen and prince and princess and all their company were imprisoned and enchanted, she then put into practice her evil plan: and taking five small books with her, alone on her palfrey, not 
taking any other company except a squire, she took the road toward the empire of Trebizond $)^{66}$

One by one, Danalia enchants the rest of the main characters, including Cristalián's grandparents, his friends at the royal court of Romania, and Cristalián himself. Finally, Drumelia chants an extended spell to build a wall of fire around the Romanian royal family: 'Anduuo en torno dellos por espacio de tres horas rezando en sus libros \& haziendo sus signos \& conjuros (She walked around them for three hours praying over her books and making signs and conjurations)' ${ }^{6} 7$ The reference to fire has a hellish dimension, and this episode suggests that Cristalián's many architectural enchantments might have been constructed through the out-loud reading of a spell.

Drumelia uses another trick to cause pain to Penamundi. She sends a messenger to Persia to tell Penamundi that Cristalián has died, when in fact he has merely turned into a bird. The messenger girl pretends to be the niece of the enchanter and apocryphal manuscript writer Doroteo, and her message borrows that purported writer's authority. Drumelia fails to account, however, for Doroteo's own communication network. Doroteo's daughter, Belsael, who serves as his representative in many episodes, appears at court and reveals that the previous message was a ruse:

Serenissimo emperador de persia el sabio doroteo mi padre revoluiendo sus libros por el su gran saber supo como Drumelia la encantadora vino a la vuestra corte por os hazer saber como el principe don cristalian era muerto (Most serene emperor of Persia, the wise Doroteo my father, upon consulting his books with his great knowledge, found out that Drumelia the enchantress came to your court to tell you that the prince Don Cristalián had died $)^{68}$

Belsael reveals that Cristalián is enchanted, not dead. Her father, Doroteo, sends yet another message, this time by letter (pargamino), to Luzescanio, Cristalián's still-free younger brother, and provides directions to Monte Despoblada ('Uninhabited Mountain'), where his relatives are imprisoned. Doroteo has outsmarted Drumelia at the enchanter's art. His books contain better information than hers do, and his messenger 
is more credible. Once again, Bernal suggests that men can beat women at the literary game.

Though Drumelia underestimates the knowledge-based arts of a rival male enchanter, Doroteo is not the root cause of her misfortune. In this episode, Bernal highlights the risks of magic, and perhaps reading itself. The prophecy that inspired Drumelia's preventative measures proves to be self-fulfilling. Drumelia would never have suffered at Luzescanio's hands had she not provoked him to ire by attacking every member of his family. As Luzescanio rides toward the castle where his family is imprisoned, Drumelia's amigo ('lover') feels honor-bound to challenge the young knight. The old man is swiftly killed, giving Drumelia in the last act of her story a real reason to hate the family against whom she has committed so many wrongs. In her grief, she returns to her library to search out new magic:

Sabed que ella se fue a su castillo y en el no se detuuo sino solo vn dia quanto a gran prissa anduuo mirando sus libros y hallo por su gran saber que el infante luzescanio lleuaua su derecho camino a la montaña despoblada por librar a todos lo que alli encantados estauan: ella procuro de hazer tales encantamentos por donde el infante no pudiesse entrar en la montaña

(Know that she went to her castle and that she did not delay even one day in her hurry to search through her books. She found through her great knowledge that the prince Luzescanio was taking the direct road to the Uninhabited Mountain to liberate all those enchanted therein. She took care to make enchantments that would keep the prince from entering the mountain $)^{69}$

Once again, Drumelia's spells fail to achieve their goal. The episode makes clear that the magical arts, especially prophecy, pose a danger to those who practice them. Drumelia had no reason to take revenge against the family; rather, she created the situation in which one of them would cause her pain. Here, Bernal suggests that active uses of the enchantress's core power can easily turn to evil. Sabias are supposed to know and to influence, not to practice offensive magic. Bernal grants female practitioners of literary magic a certain degree of agency and independence, but when they overstep the boundaries of a female magician's passive, sponsorial role, grave misfortune is the result. 


\section{Letter Writers}

Bernal's female letter writers manifest same kind of conditional agency as the female magicians. Letters potentially modeled after those in Amadis de Gaula and Tirant lo Blanch play a role in two of the love stories of Cristalián, and the intertextual dimensions of the letter episodes suggest that Bernal took great care with the articulation of this trope. The episode shows off Bernal's perspicacity as a reader of her own gerne and her acute awareness of the dangers letter writing, fictional or non-fictional, posed for women. Bernal's view of the female letter writer remains ambivalent. While the letters allow women a nominal expression of their own desires and perspectives, in one case, the exchange is so formulaic as to be meaningless, and in the other, the male recipient simply ignores the female writer's request.

In both cases, the letter exchange is two-sided but initiated by men and involves a single pair of letters. The two missives from men recall the tropes of courtly love. Each male correspondent expresses suffering on account of love and asks for a reward. The replies are more interesting, as they offer the reader two different responses to this request, one of which reflects the ideal posture for a courtly lady: pleased acceptance of the knight's suit. The other expresses only anger and irritation. The writer who acquiesces to the request, aptly named Libida, has little role to play in Cristalián except as a bland object of desire. Penamundi, who turns down the request, presents a more interesting case. I read Penamundi's anger as a citation of Oriana's letter to Amadís. For me, the refusal by letter is Bernal's most significant attempt in the volume to lend dimension to Penamundi, who lives an otherwise conventional, circumspect existence within the confines of her royal chambers. The implied command of Penamundi's letter-'go away'-hints that the princess attempts to exercise agency through the written word. As with the enchantresses, however, gendered constraints on Penamundi's behavior and emotional expression ensure that her words will not be obeyed.

María Aguilar Perdomo describes Oriana's letter to Amadís as the origin point for imitations in many other works. Female correspondents echo Oriana's anger, while men's responses mirror Amadís's despair. In Aguilar's understanding of the motif, women are overcome by unreasonable jealousy, and their response is to demand the exile of their lovers, just as Guinevere and Oriana did. $7^{0}$ The recipients of these letters experience a love-madness

Aguilar Perdomo, 'La penitencia de amor caballeresca', 129. 
that threatens both their own lives and the well-being of others. ${ }^{71}$ The narrative situation in which Cristalián and Penamundi write their letters, however, bears only superficial similarity to the conflicts between Lancelot and Guinevere and Amadís and Oriana. Bernal has her heroine write a letter of anger and dismissal to Cristalián even though he has given Penamundi no cause for jealousy. Bernal's use of Oriana's angry letter shows her ability to interpret chivalric trope against the grain, creating new meanings from old motifs. Bernal combines citations from Amadís de Gaula, Tirant lo Blanch, and Las sergas de Esplandián, re-inscribing Oriana's anger into an argument that emphasizes female authority.

Cristalián and Penamundi exchange letters after he frees her from Danalia's enchantment. At their initial meeting, Cristalián promises to visit again soon, but the adventure with the fairies at the Hondos Valles delays him. Cristalián's tardiness offends Penamundi, and by the time he returns, she no longer wishes to see him. Penamundi and Cristalián must negotiate his visit by letter because the Persian princess, like Oriana, lives in a sheltered domestic circle comprised of women. Throughout Cristalián, the hero demonstrates a puzzling disinclination to pay a public visit to the emperor's court, preferring instead to communicate directly with Penamundi. Minerva, Cristalián's friend and secretaria ('secret-keeper'), becomes their go-between, facilitating an exchange of gifts and letters. ${ }^{72}$

During Cristalián's first stay at Larenta, Minerva accepts a diamond from Penamundi as a pledge of favor and relays Penamundi's desire to know Cristalián's name and parentage. This polite request has an antecedent in the Las sergas de Esplandián. As with Cristalián and Penamundi, Esplandián and Leonorina, his destined bride, do not engage in private conversation until late in the volume. Leonorina requests, via messenger, that Esplandián pay her a visit. ${ }^{73}$ Like Penamundi, Leonorina sends a token as a proof of the message's authenticity. The messenger in Las sergas de Esplandián is a platonic female companion of the hero, the damsel Carmela; Minerva's friendship with Cristalián recalls this figure. Esplandián delays his meeting with Leonorina for various reasons, and she expresses her displeasure to Carmela and her anger to her father's court. ${ }^{74}$ Leonorina, however, writes no letters; as Montalvo's exemplar of feminine propriety, she restricts herself to reading. Yet literacy continues to be important, even in the Sergas. Spiller 
observes that 'an act of reading' unites Leonorina and Esplandián. ${ }^{75}$ When the time finally arrives to meet, Esplandián hides himself in a coffer with twin inscriptions in Latin and Greek. Leonorina reads them, understands that Esplandián has hidden himself inside, and has the box moved to her chamber, which finally allows the two to converse.

Cristalián, like Esplandián, is slow to fulfill the lady's request and uses intermediaries to communicate. He returns to Larenta still in disguise, having refused to reveal his identity to either the emperor or Penamundi. At this point, the romance enters a phase that recalls the Iberian sentimental novel. Cristalián writes a letter and first plans to send the note by his squire, which would incur a significant risk of discovery since his squire is well known to the court. Minerva, 'que muy sesuda era (who was very intelligent)', suggests that Cristalián use her as a more secure intermediary. ${ }^{76}$ Minerva then addresses an envelope to Sandalia, Penamundi's lady-in-waiting, and encloses Cristalián's letter. Her own squire takes the message to Sandalia, who passes the note to Penamundi.

As in Amadis and Diego de San Pedro's sentimental novels, the narration remains focalized on the messenger as Penamundi reads the message, and Sandalia reveals to the reader the recipient's emotions. Penamundi appears to blush: 'En las señales de su rostro bien entendio la infanta que con la letra no le auia pesado (The princess [Sandalia] understood by the signs of her face that the letter had not troubled her)'.77 The text of Cristalián's letter follows the medieval ars dictaminis structure, with the expected greeting and expressions of courtesy. Its narratio tells of Cristalián's gratitude for the favor Penamundi has shown him and declares him to be her servant. There is no specific request, but Cristalián awaits further instructions: 'Pues vuestra imperial persona me manda lo que yo dexar de hazer no pudiera andando siempre en el vuestro seruicio (It would be impossible for your imperial majesty to command me to do something that I would not do, as I walk always in your service) ${ }^{7} 7^{8}$ The erotic content of the letter is implied, not stated; Cristalián hopes to be asked to perform a task that intensifies his connection to Penamundi. Penamundi's irritable reply might come as a surprise to a reader unaccustomed to Amadis or to the sentimental tradition in Spain. Though her face seems to reveal positive emotions, Penamundi 
expresses displeasure, annoyance, and even anger once she realizes that Cristalián's letter failed to answer her request and reveal his true name.

Penamundi's reply is similar in structure to Oriana's angry letter. Both writers follow ars dictaminis, with minimal narratio and a petitio that dismisses the recipient. The writers place their accusations in the spot where, according to ars dictaminis, the captatio benevolentiae or flattering recitation of the hierarchical relationship between sender and receiver should occur. Penamundi writes:

Penamundi princesa de persia a ti el cauallero del leon: tan dichoso en auenturas como esforçado en batallas: salud a tu inuencible persona dessea. estando muy descuydada del cuydado que tu al presente tienes $[. .$.$] me dieron vna letra tuya y en ninguna Cosa satisfazes a mi Desseo:y$ pues que assi es: yo quiero responder a lo que en ella me escriues.

(Penamundi the princess of Persia writes to you, Knight of the Lion, who are as lucky in your adventures as you are brave in battle. She wishes good health to your invincible person but is quite unconcerned about the concern you have at present [...]. They gave me a letter from you which in no respect satisfies my desire, and since things are thus, I wish to respond to what you wrote to me therein. $)^{79}$

Penamundi's declaration of herself as descuydada or unconcerned over Cristalián's request occurs in the same point in Oriana's letter at which the latter names herself as 'desdichada y menguada de ventura (unhappy and unfortunate), ${ }^{80}$ Though Penamundi lacks Oriana's passion, she uses an adjective with a negative connotation. Also like Oriana, she refers to herself in third person, as if to separate herself from her emotions.

Cristalián has committed no real or imagined offense, but as the mere existence of letters from men can compromise women's reputations in both the chivalric and sentimental traditions, Penamundi's caution is perhaps justified. Yet the circumspect option would have been to make no written reply at all, following the example of Montalvo's Leonorina. Certainly, her inclusion of her own name is highly dangerous. Cristalián's letter implies a request for favor, which is even more dangerous, but Penamundi's stated reason for refusing is that she does not know Cristalián's heritage, not that offering her favor would be unchaste. The issue of parentage in this scene recalls Amadis de Gaula. Oriana and Amadís do not begin their romantic

79 Ibid., 561.

80 Rodríguez de Montalvo, Amadís de Gaula, I: 676. 
relationship until the identity of Amadís's parents has been discovered. When they meet at the window at Lisuarte's palace in imitation of Guinevere and Lancelot, their first topic of conversation is Amadís's family. Oriana congratulates him on learning his origins and being received into the family of his father and mother. ${ }^{81}$ Amadís then asks Oriana for her favor with the sexually charged word merced, which she refuses on account of propriety. Yet, as with Penamundi's letter, the fact that Oriana entertains the conversation hints that the prospect might not be wholly unappealing.

Penamundi's written rejection of Cristalián, however, is much stronger than Oriana's half-hearted rebuff of Amadís during the window scene. Instead, it channels the stronger language of Oriana's angry letter, provoked by the rumor that Amadís was unfaithful. Like Oriana, Penamundi contrasts past favor with current disapproval:

\begin{abstract}
A los grandes seruicios que de tu persona tengo rescebidos tuue por bien de hazer te en algo contento. $E$ sey cierto que este me falta y faltara hasta saber si en la genealogia de donde vienes ay merescimiento para que de las mercedes de mi a ti hechas enteramente seas capaz: y no quiero importunar te mas: pues tu voluntad es encubrir te. Tenga te dios con su mano para que tu bien auenturada fama vaya siempre a delante.

(On account of the great services I received from your person I found it appropriate to make you in some ways content. But be clear that I now lack and will always lack this goodwill toward you until I know that you are fully capable of receiving favors from me by virtue of the genealogy from which you come. I do not wish to importune you any further as you wish to hide your origins. Let God take you into his hand so that your fortunate fame may ever increase. $)^{82}$
\end{abstract}

Penamundi uses the word merced here, though Cristalián did not, making her letter a match for the erotic context of Oriana's letter to Amadís. Though Penamundi praises Cristalián's reputation, this part of the letter is in fact a rejection, analogous to Oriana's 'no parescáis ante mí ni en parte donde yo sea (do not appear before me or in any place that I am). ${ }^{83}$ Penamundi does not offer Cristalián the chance to respond, just as Oriana commanded her messenger Durín to accept no reply from Amadís. 
The letter diverges from Oriana's with its conclusion, which expresses a wish for Cristalián's good fortune rather than stating the writer's mortal despair. If Penamundi is truly angry at Cristalián at this moment and not just pretending to be so, the feeling is weak. However, the next scene featuring the two characters gives Penamundi both sufficient provocation for anger and the freedom to express it. As Marín Pina observes, in order to bring the lovers together, Bernal adapts the trope from Las sergas de Esplandián in which Esplandián conceals himself inside a carved trunk. ${ }^{84}$ Bernal echoes this artifice with one important difference: Cristalián secures no permission from Penamundi before having himself transported to her chamber.

Cristalián has recourse to an object similar to Esplandián's coffer, a hollow, golden statue of a giantess taken from the treasury at the Hondos Valles. The statue was made for observation: there is space for a person to stand or sit inside, and the eyes are transparent. Cristalián has it placed in Penamundi's bedroom, and when the two are alone, he emerges from the statue and repeats the request of his letter. Penamundi, offended that he would risk her reputation in such a way, responds with anger, forcing him to confess his parentage. ${ }^{85}$ The next moments distill the emotions present in Oriana's letter and Amadís's physical and verbal responses to it. Cristalián kisses Penamundi, angering her further. After Penamundi rejects him, Cristalián tries to kill himself, and Penamundi stops him. While this setup might lead the reader to expect a sexual liaison analogous to those of Amadis or perhaps even Tirant lo Blanch, Bernal follows the more circumspect model of Las sergas de Esplandián in the resolution of the episode. Penamundi talks with Cristalián into the night, but with Minerva's help, she locks him in her closet (retrete) when it is time to sleep. Fortunately, Cristalián also took from the treasury a magical plate and cup that provide food and water, so although he is quite lonely, he does not suffer hunger or thirst. ${ }^{86}$

Montserrat Piera and Jodi Shearn have suggested that the letter exchange episode and especially Minerva's role as a messenger recall the nocturnal liaison of Tirant and Carmesina in Tirant lo Blanch, which the damsel Plaerdemivida mediated. ${ }^{87}$ Tirant might well have been a secondary model for the letters between Cristalián and Penamundi. In my opinion, Bernal prefers Amadis as a model for the composition strategy of the letters, but Tirant informs the communicative situation. In Tirant, the knight sends and

84 Marín Pina, 'Beatriz Bernal', 300.

85 Bernal, Cristalián de España, 2014, 593-94.

86 Ibid., 597-98.

87 Piera and Shearn, 'Gendering Action', 85. 
receives a letter while residing in the outskirts of the city, and the female letter writer expresses her negative opinion of his behavior. However, the similarities largely end there, as the letters in Tirant do not adhere to ars dictaminis or refrain from expressions of sexuality. The letters between Tirant and Carmesina connect the diction of the body to emotion, as those of Amadis did, but they employ a lesser degree of circumlocution. If a third party had read Oriana's letter, they would not know the full extent of the writer's sexual transgressions, while a person who read Carmesina's would have little doubt about what had happened in her bedroom.

Tirant's letter to Carmesina references the episode in which the servant Plaerdemivida helps him invade Carmesina's bedchamber and grope her during the night. The motif might have been a reference point for Bernal, as Plaerdemivida hides Tirant in a trunk with an opening that permits observation, as the statue of the giantess in Bernal does. However, Plaerdemivida is decidedly a go-between and not a chaperone, and unlike Minerva, she encourages Tirant in behavior that, while it falls short of sexual intercourse, imperils Carmesina's chastity. Carmesina screams when she discovers a man in her bed, and in the confusion that follows, Tirant jumps out a window and breaks his leg.

The letter exchange occurs during Tirant's convalescence. The first missive, from Tirant to Carmesina, does not apologize for his bad behavior, but rather expresses satisfaction at the fact that his broken leg has moved his lady to pity. ${ }^{88}$ Plaerdemivida, naturally, has kept him informed of his lady's mental state. Carmesina replies to the letter, expressing her displeasure at the liberties Tirant took but rebuking him only gently:

I feared to take pen in hand, for while writing with friendship, I felt obliged to show my indignation. Though my grief has redoubled, I shall bear it patiently all my life, knowing that such cruelty and love were never seen together. This thought alone forces me to reply: to make you see that your hands, which learned a new trade and pitilessly seized pleasure, now deserve no pardon from the lady you have wronged [...]. So great was my distress that I cried out 'Jesus, Jesus, Jesus!' thus confessing my grief [...] he who errs deserves no pardon, and your punishment will be such that you will think no more of me, nor I of you. ${ }^{89}$ 
The letter is a rejection notice, which brings it into line semantically with Oriana and Penamundi's letters. However, its composition strategy differs from those letters in two ways. The ars dictaminis formulary is not the model for this composition, as there is no salutation or hierarchical language to situate writer and recipient. Carmesina, moreover, is less given to metaphor, circumlocution, or politeness than Oriana or Penamundi. Carmesina mentions 'hands', not to represent metaphorically her emotional grief, but in literal reference to the groping she suffered. Moreover, she hints that the ire the letter expresses is feigned: she feels 'obliged' to seem angry, and she writes in 'friendship'.

Another message from Carmesina to Tirant, which occurs long after any veneer of ire at the clumsy groping has faded, reveals that Carmesina is indeed a very different correspondent from Oriana and Penamundi. Carmesina sends the second letter to Tirant while he is out on chivalric errand to tell him that she misses him and to request that he return. Her frank sexual diction would be unthinkable in the world of Amadís or Cristalián: 'I would pace about the room, saying: "Tirant sat here, he held me here, here he kissed me, here we lay together naked [...] may such thoughts ease with your coming, which will end my woes'.$^{90}$ This letter likewise contains no greeting or polite hierarchical language. For me, Penamundi's letters bear a closer relationship to the ars dictaminis-inspired letters of Amadís, which express emotion but refer to a messenger for details. When Penamundi and Oriana reference sexual matters, they do so through circumlocution, and they spend most of the letter's length on hierarchy and the command. Though Tirant might well have influenced the global architecture of Cristalián and Penamundi's love affair, particularly his illicit sojourn in her chamber, Carmesina does not appear to be Penamundi's primary correspondence model.

The question remains of why Penamundi would write at all. If she wishes to ignore Cristalián, the most efficient way would be to do so completely, without sending a note. In my mind, her letter shares with Carmesina's and Oriana's its role in asserting her power over the male recipient. This secret communicative goal is much more important to Penamundi than the letter's actual request, which is weak. Yet unlike Oriana, Penamundi has little power to move Cristalián by letter. Instead of raving or lamenting his fate, Cristalián simply devises a way to speak to the princess. Penamundi's letter has a nearly null effect. The provocation was slight, the reunion between the characters has lower stakes, and the knight is granted his initial request (his lady's favor), though in a chaste manner. No wars or future monarchs have their origin point in the immediate aftermath of this letter exchange. However, during the 
in-person meeting brought on by the letter, Penamundi succeeds in imposing her will on Cristalián. He must accept her boundaries and spend the night in the closet. Though Cristalián ends before the couple can undertake a joint rule, Bernal perhaps hints with the resolution of the letter episode that their relationship is more egalitarian than most pairings on the courtly love model.

Indeed, Penamundi's relative power over Cristalián becomes more evident when her letter is compared to the only other cited letter from a woman in Cristalián de España, the placid message from Libida to her new admirer Dismael. The character Dismael features in Cristalián's most salacious plots; he climbs into one damsel's window and forces her into a sexual relationship, and when she suddenly dies, he transfers his allegiance to Libida. After a brief acquaintance with Libida, Dismael leaves on chivalric adventure, as Cristalián did shortly after he met Penamundi. Dismael writes a rather obsequious letter apologizing for a long absence from his beloved. Instead of replying in anger as Penamundi did, Libida soothes her knight's feelings:

Libida, reina de Armenia, a ti Dismael de la Roca, Príncipe de Macedonia, salud y victoria contra tus enemigos desea [...] recibo mucho placer en saber que gastas tu tiempo en mi servicio. Yo te ruego tengas por bien, cuando para ello lugar tuvieres, de visitar este reino

(Libida, the queen of Armenia, wishes health and victory against your enemies to you, Dismael de la Roca, Prince of Macedonia [...]. I take pleasure in knowing that you spend your time in my service. I pray that you will find it in your heart to visit this kingdom when you have time) $)^{91}$

Libida and Dismael have little need to communicate, as there appears to be no conflict in their relationship. It is puzzling, indeed, that Bernal should have included letters from them at all, except as a counterpoint for the letters of Cristalián and Penamundi. Through this conventional, dull pair of letters, Bernal shows what correspondence between a man and an acquiescent courtly lady would look like. Libida requests that Dismael visit in polite and contingent terms, and he can feel free to ignore her if he likes. Libida uses the ars dictaminis structure at its most respectful; though Dismael is her knight, she presents herself as his equal or even inferior. This passivity on the part of the lady of courtly love reflects the behavior E. Jane Burns described as the ideal for women in such partnerships in medieval French literature. ${ }^{92}$ Penamundi's letter takes greater risks and is 
more forceful in expressing her point of view. Even though her lover does not obey her command, Penamundi nonetheless attempts to use writing to make a decision about her erotic life.

The question remains of whether Bernal ultimately supports the agency of female characters as expressed through the practice of reading and writing. The resolutions of the episodes I have discussed tend to be ambivalent, and, debatably, all reading and writing women in Cristalián experience some measure of punishment for their efforts. Membrina succeeds in promoting the fortunes of Lindedel and his family, but once Lindedel builds his empire, he neglects his aging patroness. Celina's story ends in a marriage to the partner of her choice, but it is unclear whether she maintains her autonomy within that marriage. The evil sabias reap the punishment poetic justice holds out for them. The sole exception among that group, the lady with the sparrowhawk, will perhaps take an apprentice someday, mistreat her, and learn firsthand the fate of women whose reach exceeds their grasp. Penamundi and Libida succeed, at least in part, in their attempts at communication; Cristalián reveals his name to Penamundi and becomes more frequent in his visits, and Dismael remains dedicated to his bland paramour. Both letter-writing couples are ready to marry at the end of the volume, when an unexpected calamity that is perhaps a saving grace interrupts them.

At the collective wedding ceremony at the end of the volume meant to unite all the characters of the romance in neat pairs, a whirlwind sweeps the characters to a new fairy adventure. Bernal's final deus ex machina denies some characters a long-awaited pleasure but saves others from having to fulfill promises they did not make willingly. For just one example, Cristalián promised Minerva to the Duke of Fonteguerra, her greatest enemy. The apocalyptic ending of Cristalián returns to the double bind that embitters the lives of the work's female practitioners of magic. Women's agency is contingent, and women largely possess it when they are single, either when they are young objects of desire, capable of inspiring a man's obedience, or if they reject the most privileged life path for women-marriage and motherhood - and resign themselves to isolation. The whirlwind refuses to choose between these options for some of Cristalián's major players, infinitely deferring the question of how and whether women can rule their own lives.

Bernal's own story suggests that the question of women's literacy remained fraught with conflict in mid-sixteenth century Valladolid, even for a woman who slipped through many of the cracks in the patriarchal system. Bernal had access to learning and reading, and from a variety of contemporary options, some of which would have been more circumspect, 
she chose the romance of chivalry as a vehicle for a narrative that imagines female characters as numerous and important. Bernal combines the most exceptional episodes about women from her reading materials to create a relatively gender-neutral world in which female characters frequently go on adventure. However, she also replicates some of the constraints that ruled the lives of Golden Age women; none of her literate women escape their stories unscathed. Indeed, some of the punishments these women endure are worse than those imagined by Montalvo and other chivalric writers, who attacked female characters more directly with misogynist language.

Bernal's doubled message, of women's power and the limits to that power, might well be directed at female readers. In the proemio, the author-figure walks through the church in the company of other un-named women. These silent figures might also be the author's companions throughout her narrative, which she directs in a conversational tone to readers of unspecified gender. The sheer number and variety of Bernal's female characters suggest that she always has women in mind, and the fact that so many of them read and write hints at a link to the extradiegetic woman reader. If Bernal's romance is, at least in part, written for women, then it offers them a message of both hope and caution. Women have physical and intellectual strength, but they still must play by a set of rules more constricting than those articulated for men. However, submission to men is not inevitable; it can be infinitely deferred, both by scholarly practice and by fairy magic. Though Cristalián is not a work of pure, counter-factual fantasy, it does suggest a form of incremental progress for chivalric women, including chivalry's women readers. 



\section{The Triumph of Women Readers of Chivalry in Don Quixote Part I}

By the time Miguel de Cervantes evoked Amadís of Gaul as his hero's primary target for imitation in Don Quixote Part I (1605), the romance of chivalry had lost much of its cultural cachet in Spain. ${ }^{1}$ Beatriz Bernal's Cristalián was among the last group of new romances to emerge in print, and what little chivalric publication continued during the reign of Felipe II was largely confined to editions of already known romances. ${ }^{2}$ In Cervantes's context, it was perhaps not possible to view books of chivalry as sacred objects capable of sustaining narrative authority, as Bernal does in her proemio. For Cervantes, chivalric romance is indeed a relic, but not an authoritative one. The reading of chivalry, transgressive in Bernal, becomes risible in Cervantes. Indeed, if one considered only Don Quixote's too-literal reading practices, it would be logical to conclude that Cervantes expresses a categorical denouncement of chivalric romance in his novel. The mad knight, however, is not the only reader of chivalric fiction in Don Quixote, nor is he the final arbiter of what romance tropes mean or how they can be used.

The next two chapters of this book will examine the fates of four inscribed female readers in Cervantes's novel_Luscinda and Dorotea from Part I, and the duchess and Altisidora from Part II — who echo the essential quixotic drive to apply literature to life. Although Cervantes mocks the romance of chivalry, he also celebrates it, primarily through the genre's women readers. Cervantes eulogizes the masculine plotlines of Iberian chivalric romance while preserving one of its most radical features, the agency it grants female characters through the written word. In this chapter, I discuss how Luscinda and Dorotea partner to out-Quixote the other readers gathered at Juan Palomeque's inn. These two seemingly naïve young women use chivalric romance as a handbook of creative solutions for the predation of men.

Far from representing the reading of chivalry as a masculine, aristocratic pursuit, Cervantes goes to great lengths throughout Don Quixote Part I to emphasize the diversity of romance readers. A work of fiction, of course, cannot be taken as a historical document, especially for a slippery phenomenon like readership, but various scholars have examined the readers Cervantes depicts and found them historically plausible. Elizabeth Spiller, tracing the

1 Girard, Mensonge romantique et vérité romanesque, 3.

2 Eisenberg, Romances of Chivalry, 48. 
connections between Cervantes and others who wrote about reading in the Golden Age, characterizes Don Quixote as a virtual laboratory that offers 'a literary history of how romance reading changed in the previous hundred years'. ${ }^{3}$ For Lisa Vollendorf, the fact that women are among Cervantes's inscribed readers reflects real women's increasing access to literacy and literary culture during the author's lifetime. ${ }^{4}$ For Cervantes, reading has the potential to cut across class and gender lines, and some 'readers' are illiterate listeners of texts. Cervantes's fictional consumers of chivalric literature in Part I include Don Quixote himself, the priest, the barber, innkeeper Juan Palomeque, the innkeeper's daughter, the servant girl Maritornes, the canon of Toledo, Cardenio, Luscinda, and Dorotea. These characters range from the low nobility to the working poor, with women appearing at both ends of the social spectrum. They converge on a single physical space, the inn in Sierra Morena, and their interlacing stories reflect different responses to the same reading material. Cervantes's women read quite differently from the men, in ways both expected and unexpected. Far from reiterating the conduct tradition's clichés about female readers, however, Cervantes complicates the question, playing with and at times circumventing the stereotypes.

Maritornes and the innkeeper's daughter, the two lower-class women consumers of chivalry featured in Part I, experience the texts through out-loud reading. With little social position to lose, they are freer than upper-class women to admit to using chivalry as an inspiration for erotic fantasies, just as the conduct tradition warned women would do. Adrienne Martín compares Maritornes, who enjoys chivalric love scenes, to Don Quixote in her desire to reinterpret her own experience as a rural prostitute through literary trope. ${ }^{5}$ The innkeeper's daughter, meanwhile, prefers a related motif, the love-laments of knights. ${ }^{6}$ These two women do indeed imitate their favorite literary genre, though in a parodic fashion. They entice Don Quixote to believe that he is participating in a nocturnal meeting like that of Amadís and Oriana at the window, instruct him to put his hand through a hole in the stable wall, and tie it to trap him in place. They do not gain erotic gratification from the encounter, but they do seem to delight in using their knowledge of chivalric trope to ridicule Don Quixote. ${ }^{7}$ 
Luscinda and Dorotea demonstrate a more sophisticated approach to literary imitation than Maritornes and the innkeeper's daughter. They are explicitly literate, and they combine strategies from chivalric romance and other literary sources including the sentimental novel, Ovid's Heroides and Metamorphoses, the conduct tradition, and Tasso's Gerusalemme Liberata. Cervantes thus renders these characters inscribed readers not just of Iberian chivalry, but of other genres with more literary prestige. Luscinda and Dorotea's aptitude for comparison, imitation, and parody mirror the authorial habits of Cervantes himself. E. Michael Gerli explains that 'as [Cervantes] wrote he would critically read, assimilate, deconstruct, and as it were, rewrite — often write against — not just discrete literary traditions but also a broad spectrum of texts and discourses ranging from abstract Renaissance literary theory to specific legends, textual typologies, even his own prior versions of a passage'. ${ }^{8}$ For Gerli, Cervantes's governing citation principle is 'ironic reversal followed by reconstruction'. Expanding on Gerli's paradigm, I would characterize Luscinda and Dorotea as constructive readers who use reading to craft new realities. These two women succeed in reconciling chivalric romance with the literary climate at the end of the sixteenth century, especially its neo-Aristotelian appreciation for verisimilitude. Luscinda and Dorotea accomplish what Cervantes's canon and priest merely talk about in the end of Part I: rewriting the romance of chivalry to suit the demands of a 'real' world.

\section{Luscinda's Letters}

Luscinda, a young woman from a noble family of modest means, lives a conformist existence relieved by the entertainments of reading and falling in love. Yvonne Jehenson writes that, in general, the women of Don Quixote are 'controlled by the requirements of a good reputation, the expectations of a good marriage, and their own naiveté - the latter resulting from a sheltered education'. ${ }^{9}$ Luscinda might seem to fit Jehenson's template in that she remains mostly at home and forms a romantic attachment to one of the few men she knows, her neighbor Cardenio. However, Luscinda is not as guileless as Jehenson would expect: she manipulates her family, Cardenio, and Fernando through words and actions adapted from chivalric romance, Ovid, the sentimental novel, and the legend of Roman matron 
Lucretia. Luscinda's reworking of chivalric motifs to assert control over her fate follows Gerli's principle of ironic reversal, and she undergoes a series of transformations in her love affair with Cardenio as she alternates among various literary models. In turn, her imitations put pressure on Cardenio to react in the way the literary model prescribes. In my discussion of Luscinda's reading practices, I contrast them with Cardenio's to explore how the couple's reading habits both conform to and subvert gender stereotypes. Some of the dangers of reading chivalry appear to be gender neutral, while others can afflict the 'wrong' gender under certain circumstances.

The overall framework of Luscinda and Cardenio's relationship mirrors that of Amadís and Oriana in Amadis de Gaula. In his analysis of the episode, Stanislav Zimic observes that both pairs of lovers promise eternal love and take on the institutions of patriarchy and nobility, sustaining their pact only 'at the cost of great suffering, sacrifices, and risk of death'. ${ }^{10}$ Cardenio and Luscinda are neighbors, like Amadís and Oriana, but rather than the heirs of neighboring monarchs, they are the scions of equally noble families. Both couples meet and fall in love as children and are separated in adolescence. The lady's father is the obstacle to marriage in both cases. In Amadis de Gaula, the emperor of Rome persuades Oriana's father, Lisuarte, to ignore his daughter's opinion and betroth Oriana to him. Luscinda's father makes much the same decision when Fernando, the second son of a duke, offers his hand. In Amadís, civil war, with all the collateral damage it implies, is required to make things right. In Don Quixote, a smaller-scale family disturbance erupts. The conflicts that haunt Cardenio and Luscinda center around four texts: two letters from Luscinda, and a letter and a poem from Cardenio. The insistent textuality of the episode recalls Montalvo's treatment of Oriana's angry letter, suggesting that for Cervantes, the entire episode is a meditation on the relative agency men and women may exercise through the written word. Both genders, indeed, fall short of the communicative goals they express in their missives, though Luscinda eventually accomplishes hers by other means.

'Pyramus and Thisbe', from Book IV of Ovid's Metamorphoses, provides another structural model for Cardenio and Luscinda's star-crossed love, revealing the relationship's potential for disaster. The Ovidian lovers attempt to circumvent parental opposition by conversing through a crack in the wall and arrange a nighttime assignation that ends in their deaths. After escaping her parents' home, Thisbe encounters a lion and is forced to flee. Pyramus, who finds her bloodied mantle, assumes that she has been killed 
and commits suicide. When Thisbe discovers her beloved's body, she ends her own life. While Cardenio and Luscinda have an outcome more like Amadís and Oriana's, were it not for the quick thinking of Luscinda and Dorotea, the episode might have concluded with the death of one or both of the lovers. Reading and literary imitation are key components of the relatively happy resolution of Luscinda and Cardenio's story. Luscinda can make her words travel across distance through letters, and her reading gives her models that allow her to gauge the outcome of her communication.

Cardenio, for his part, evokes Ovid directly in his narration of the love affair to Don Quixote and Sancho, and it is quite likely that the Metamorphoses is a shared reading material for the couple. ${ }^{11}$ Cardenio remarks that Luscinda's father restricted his access to her house, 'imitando en esto a los padres de aquella Tisbe tan decantada de los poetas (imitating in this regard the parents of that same Thisbe praised so often by poets)'. ${ }^{12}$ Pyramus and Thisbe's story contains no mention of literacy or texts, but their love affair, like that of Luscinda and Cardenio, breaches physical absence with words:

The walls that divided the two estates had a tiny hole, a cranny formed long ago at the time the partition was built. In the course of years, this imperfection had never been noticed but what is not sensed by love? The lovesick pair were the first to find it, and used it to channel their whispered endearments in safety. ${ }^{13}$

The wall that separates the lovers finds an echo both in Cervantes and in Amadís de Gaula. Cardenio and Luscinda meet by night at the bars of her window, as do Amadís and Oriana and their own antecedents, Lancelot and Guinevere. ${ }^{14}$ Cardenio and Luscinda's letters are analogous to words whispered through cracks in the wall; in fact, Luscinda's decision to write to Cardenio may draw inspiration from 'Pyramus and Thisbe'. The veil Luscinda is wearing when she arrives at Juan Palomeque's inn recalls Thisbe's mantle,

11 Ovid's works, particularly the Metamophoses, were well known in Spain during Cervantes's era. Rudolph Schevill and Frederick de Armas note the proliferation of Spanish translations of Ovid, and William Worden argues that Ovid's Metamorphoses provides an organizing device within Don Quixote Parts I and II, as Cervantes 'depicts transformations of all kinds'. For example, in Part II, the knight's guide to the Cave of Montesinos declares himself to be working on a book entitled the Metamorfoseos, or the Ovidio español. See Schevill, 'Ovid and the Renaissance in Spain', 147-48; De Armas, 'Captured in Ekphrasis', 241-42; Worden, 'Cervantes Transforms Ovid', 116.

Cervantes Saavedra, Don Quijote, I, 24; 293; Cervantes Saavedra, Don Quixote, 184.

Lida de Malkiel, 'Arthurian Literature', 414. 
and Luscinda's feigned or real attempt to stab herself may be an imitation of Thisbe as well as Lucretia. If Luscinda indeed chooses to imitate Thisbe, she likely does so to heighten Cardenio's awareness of the danger they face. Luscinda's invocation of Ovid, whether deliberate or accidental, has a visceral affect on Cardenio. When Quixote and Sancho meet Cardenio, starvation and exposure have weakened him to the point that he risks imitating Pyramus and causing his own death.

Luscinda, however, does not restrict herself to the Metamorphoses as a model for behavior. A sophisticated reader of epistolary fictions, Luscinda channels Oriana and the female letter writers of the sentimental tradition as well as Ovid's Heroides in her letters to Cardenio. From Amadís de Gaula, Luscinda adapts Oriana's ability to command her lover through the written word. From the sentimental novel, Luscinda adapts the language of honor and duty that renders erotic relationships legal contracts. From Ovid's Heroides, Luscinda takes diction that externalizes emotion by mapping it onto the body. Through Luscinda, Cervantes re-interprets the female chivalric correspondents this book featured in Chapter One. María Carmen Marín Pina observes that in chivalric romance, many women write letters of reproach or reconciliation, while a select few 'take the initiative and dare to declare their love in writing'. ${ }^{15}$ Luscinda's letters express feelings, as chivalric letters do, but they surpass chivalric missives by pairing emotion with information.

Oriana and Luscinda are both meek conversation partners and bold correspondents. In Amadis de Gaula, Oriana brokers her rupture and reconciliation with Amadís through letters. Luscinda writes to Cardenio throughout their relationship, first 'regaladas y honestas respuestas (delicate, virtuous responses)', and then missives that contain commands. ${ }^{16}$ The first of Luscinda's letters cited in Cervantes's text is a veiled proposal of marriage. It alludes to emotion, but the diction is practical:

Cada día descubro en vos valores que me obligan y fuerzan a que en más os estime: y así, si quisiéredes sacarme desta deuda sin ejecutarme en la honra, lo podréis muy bien hacer. Padre tengo, que os conoce y que me quiere bien, el cual, sin forzar mi voluntad, cumplirá la que será justo que vos tengáis, si es que me estimáis, como decís y como yo creo.

(Each day I discover in you virtues that oblige and compel me to value you even more; and therefore, if you wish to free me from this debt without

16 Cervantes Saavedra, Don Quijote, I, 24; 293; Cervantes Saavedra, Don Quixote, 184. All English citations from Don Quixote are from Edith Grossman's translation. 
attaching my honor, you could do so very easily. I have a father who knows you and loves me, and he, without forcing my will, can meet the obligation of what it is reasonable for you to have, if in fact you value me as you say, and as I believe you do. $)^{17}$

Luscinda encloses her letter in the volume of Amadis de Gaula she borrowed from Cardenio. For Spiller, this gesture serves to remind readers that Luscinda is imitating Oriana. ${ }^{18}$ Cardenio, who shares Luscinda's knowledge of Amadis, would understand that Luscinda feels a faithful, passionate love that mimics Oriana's, even though her diction is neutral rather than effusive. Luscinda's communication is a partial success. Cardenio does speak to Luscinda's father, who declares that a proper proposal must come from Cardenio's father. The latter, however, presents a letter from an Andalusian duke demanding Cardenio's service, delaying his son's plans for marriage.

Luscinda's second letter again prods Cardenio to action. In the intervening weeks, Cardenio has developed a friendship with the duke's second son, Fernando. Luscinda warns Cardenio that his friend has betrayed his trust:

La palabra que don Fernando os dio de hablar a vuestro padre para que hablase al mío, la ha cumplido más en su gusto que en vuestro provecho. Sabed, señor, que él me ha pedido por esposa, y mi padre, llevado de la ventaja que él piensa que don Fernando os hace, ha venido en lo que quiere, con tantas veras, que de aquí a dos días se ha de hacer el desposorio [...]. Cuál yo quedo, imaginaldo: si os cumple venir, veldo: y si os quiero bien o no, el suceso deste negocio os lo dará a entender.

(Don Fernando's promise to you that he would speak to your father about speaking to mine has been carried out more to his pleasure than to your benefit. Know then, Señor, that he has asked for my hand in marriage, and my father, carried away by the advantage he thinks Don Fernando has over you, has agreed to everything he wishes, and with so much enthusiasm that in two days' time the betrothal will take place [...]. Imagine the state I am in; if you come, you will see it, and you will know, in the outcome of this business, whether I love you dearly. $)^{19}$

Luscinda's second letter is more modern than the ars dictaminis-inspired chivalric missives discussed in the previous chapters. It contains emotion 
and a command, as Oriana's letters do, but it also introduces a new plot point and gives Cardenio the information he needs in order to determine his next action. Thomas Beebee characterizes non-literary letters from this period as possessing 'an unstable status between fiction, sermon, news, and gossip'. ${ }^{20}$ Chivalric letters rarely contain news, which messengers must transmit verbally. Luscinda here improves on her correspondence model, making it suited for a context in which a messenger cannot be trusted to relay information and in which the letter must stand for itself.

Luscinda, moreover, improves the efficacy of her communication by subtracting as well as adding to Oriana's model. Luscinda refrains from jealous rage, leaving all irrational expressions of emotion to Cardenio. Cervantes thus refuses to link Luscinda with negative stereotypes about women in general and female chivalric correspondents in particular. Despite the fact that Luscinda is the correspondent who deliberately invokes Amadis by inserting her letter into the book, Cardenio's communications sound more like Oriana's letters than Luscinda's do. It is he who expresses sadness, jealousy, and rage, as Oriana did. By scrambling the gender polarities of his borrowings from Amadis, Cervantes brings into question the gendered hierarchy at the root of the love conflicts. Cardenio, in particular, offers a meditation on gender and reading, as he falls prey to the reading practices that the conduct tradition and other critics of romance identify with women.

Cardenio's letter and poem strongly recall the letter and poem exchange between Amadís and Oriana. In Amadís de Gaula, Oriana hears a rumor that Amadís has been unfaithful and then writes a letter asking him never to contact her again. Her conclusion hints that she will soon die of grief. Amadís receives the letter by messenger and sends no reply, as his lady had instructed. Instead, Amadís writes a ballad that expresses both his innocence and a wish for death: 'Pues se me niega vitoria / do justo m'era devida / allí do muere la gloria / es gloria morir la vida (Because a just victory is denied to me, there where glory dies, death will be my glory). ${ }^{21}$ Minstrels later deliver the message of the ballad to Oriana by hearsay. Both Oriana's and Amadís's compositions are rich in emotion and light on information. Indeed, their messages are dependent on the recipients' prior knowledge of the context and the messengers' skill in reporting pertinent facts.

Cardenio's poem contains a message similar to Amadís's ballad: 'O le falta al Amor conocimiento / o le sobra crueldad, o no es mi pena / igual a la ocasión que me condena / al género más duro de tormento (Either love 
has too little understanding / or too much cruelty, or else my grief's / not equal to its cause though it condemns me / to suffer this, the harshest kind of torment) ${ }^{22}$ Cardenio's use of the pseudonym Fili (Phyllis) later in the poem hints that it is not love itself that he believes to be cruel, but Luscinda. Both Cardenio's and Amadís's poems declare their innocence, but only Cardenio attributes fault to his beloved. As David Quint points out, Amadís takes the blame because he caused his lady pain, however accidentally. ${ }^{23}$ By contrast, Cardenio reflects the misogyny that haunts interpretations of Oriana's letter. As Chapter One relates, readers, starting with Montalvo himself, have often commented on Oriana's jealousy, marking it as a particularly feminine failing.

Cardenio's 'carta misiva' on the next page of the memory book is every bit as impassioned and unreasonable as Oriana's letter, showing that for Cervantes, the emotion of jealousy does not belong exclusively to women. He writes:

Tu falsa promesa y mi cierta desventura me llevan a parte donde antes volverán a tus oídos las nuevas de mi muerte que las razones de mis quejas. Desechásteme, ¡oh ingrata! por quien tiene más, no por quien vale más que yo [...]. Quédate en paz, causadora de mi guerra.

(Your false promise and my certain misfortune have taken me to a place from which news of my death will reach your ears before the words of my lament. You rejected me, $\mathrm{O}$ ungrateful lady, for one who has more than I, but not one of greater worth [...]. Go in peace, cause of my conflict. $)^{24}$

Cardenio's opening recalls Oriana's 'Mi raviosa quexa acompañada de sobrada razón (My furious complaint accompanied by more than enough reason)'. ${ }^{25}$ The two letters begin not with the writer, but with an adjectival phrase presenting his or her complaint. Both letters reference a rival, though not by name, and accuse the recipient of infidelity. They make the same basic request, 'go away': Oriana's 'no parescáis ante me ni en parte donde yo sea (do not appear before me or in any place that I am)' is similar to Cardenio's 'Quédate en paz (go in peace)'. In addition, both letters state that the writers will soon die of the pain they feel. The difference between the two letters is that Oriana's transmits a message to her reader. Oriana gives her letter 
to the servant Durín, who delivers it to Amadís. Cardenio, however, has abandoned his letter in the dust. With this incomplete communication, Cervantes perhaps hints that Cardenio's composition strategy and the misogyny that underlies it are relics best left behind.

Chivalric correspondence serves Luscinda because she adapts only those parts of it that function in her world. She uses letters to command her beloved, as Oriana does, and to work around her father's consent, but she adapts the structure of the missives themselves for a context in which letters need to carry news. Yet unlike Oriana, Luscinda cannot get what she wants with a one-sided correspondence. The difficulties Luscinda and Cardenio encounter in creating a two-way letter exchange evoke another major correspondence model, the Iberian sentimental novel. In the sentimental tradition, the materiality of the letters themselves and the contexts in which they are transmitted tend to have negative consequences for communication. Spiller writes that in Cervantes, 'the pure love letters of the Amadis become material objects that can be misdirected, misread, sold, stolen, or lost'. ${ }^{26}$ However, as Chapter One shows, the letters of the 1508 Amadis do indeed have material specificity. Montalvo depicts Oriana writing her angry letter with ink and parchment and then describes the finished letter's envelope, wax seal, and stamped heraldic device. Oriana's letters are subject to time, distance, and the whims of messengers, as when Durín accuses Oriana of murdering Amadís with her words. ${ }^{27}$ I would argue that the difference between Oriana's and Luscinda's letters has less to do with materiality than with the intervening model of Diego de San Pedro's sentimental novels, in which women's letters utilize the language of honor, duty, and reputation, and men ignore women's words in favor of bodily signs.

According to Marina Brownlee, the chivalric and sentimental traditions influenced each other, and for Barbara Weissberger, they are similar enough to be considered members of a single genre. ${ }^{28}$ Both genres include a mix of letters and narration. Don Quixote, however, adapts some features of Diego de San Pedro's novels Arnalte y Lucenda (1491) and La cárcel de amor (The Prison of Love, 1492) that do not appear in Amadis. Dorothy Severin discusses several connections between Arnalte y Lucenda and the Cervantine episode, noting the similar names of Lucenda and Luscinda, the depiction of the lover 
as a suffering wild man, the betrayal by a friend, and the lady's retreat to a convent. ${ }^{29}$ Although Arnalte y Lucenda did not circulate widely in Spain during Cervantes's lifetime, Severin believes that Cervantes might have known it in French or Italian translation. Cervantes would almost certainly have known La cárcel de amor. ${ }^{30}$ For Severin, Cervantes's imitation of San Pedro's sentimental novels is partial: 'The epistolary form is merely hinted at and not exploited. ${ }^{31}$ Cervantes's sentimental episode contains fewer letters and more narration than San Pedro's sentimental novels; structurally, it bears greater resemblance to the epistolary episodes of Amadís de Gaula. Yet thematically, Luscinda's letters have much in common with women's letters in the sentimental tradition. For San Pedro's Lucenda and Laureola and Cervantes's Luscinda, bodies are commodities for exchange, love is a service that incurs a debt, and men, even men in love, have an obligation to protect a lady's reputation. By evoking the sentimental novel, moreover, Cervantes hints that Luscinda, as an inscribed reader, is sophisticated enough to imitate and recombine different correspondence models for rhetorical effect. The intertextuality of her letters hints not at an inexperienced writer reacting to overwhelming emotions, but at the calculation of an author.

Luscinda's first letter uses economic metaphors to persuade Cardenio to propose marriage. The verb obligan ('oblige') and the noun deuda ('debt') evoke duty both moral and financial. Luscinda's use of valores ('virtues' or 'values') and estime ('esteem' or 'estimate') to evaluate her potential partner looks forward to the economic metaphors for women's honor Lotario employs in the interpolated tale El curioso impertinente several chapters later, including the luxury goods finísimo diamante ('finest diamond') and arminio ('ermine'). Quint identifies the love triangle of El curioso impertinente as an intertext for the Luscinda-Cardenio-Dorotea-Fernando affair, and the fact that metaphors from the same semantic field apply in both places implies that manipulation is as much at work in Cardenio and Luscinda's story as it is in the more transparent interpolated novella. ${ }^{22}$ Spiller characterizes the monetary implications of Luscinda's letters as a response to the print industry: 'At each new narrative level the basic thematic elements of the epistolary exchange between Amadís and Oriana reappear, but they do so in increasingly material, mercantile, and public forms' ${ }^{33}$ Luscinda uses

33

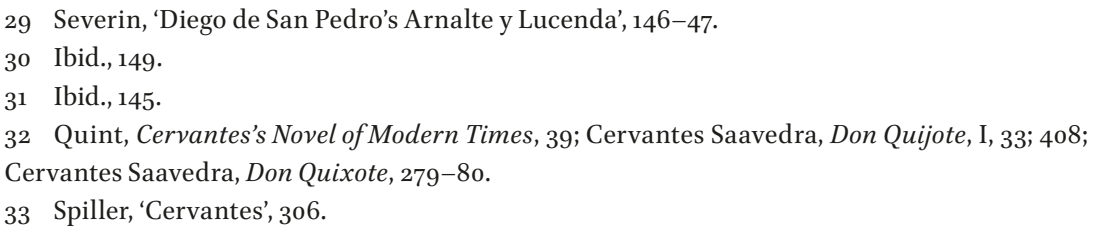

32 Quint, Cervantes's Novel of Modern Times, 39; Cervantes Saavedra, Don Quijote, I, 33; 408; Cervantes Saavedra, Don Quixote, 279-80. 
antiquated genre references to produce a modern product, and in so doing, she seeks to subvert traditional gender norms. Luscinda manipulates Cardenio through their shared reading material in order to secure another modern commodity, a marriage based on mutual affection rather than family prerogatives.

Like her chivalric and sentimental antecedents, however, Luscinda is only partially successful in persuading her reader. Cardenio attempts to bring about a parentally sanctioned betrothal, but he is distracted by other business and fails to formalize the bargain. Luscinda's second letter employs the language of obligation to warn Cardenio of a broken contract. Fernando has broken his word to Cardenio and attempted to make his own contract with Luscinda's father. Luscinda uses two forms of the verb cumplir ('to fulfill'), reinforcing the notion of marriage as a business negotiation. If the first letter was a proposal of marriage, and Cardenio's actions an attempt to accept, it can perhaps be argued that Cardenio and Luscinda entered into a precontract to marry. However, Luscinda's father threatens this tenuous business deal through his contradicting betrothal of Luscinda with Fernando. The semi-public ceremony of the desposorio, if completed, would likely supersede Cardenio and Luscinda's private betrothal. Luscinda's second letter thus asks Cardenio to weigh two contracts against each other and decide which is the most valid.

In the sentimental tradition, women use the language of economics a bit differently, to discourage unwanted admirers rather than to entice a beloved to act. In Arnalte y Lucenda, Arnalte indulges in dangerous and threatening behavior. He cross-dresses in order to talk to Lucenda at church, coerces her into dancing with him at court, follows her to her lodgings, and arranges to spy on her from his friend Elierso's nearby dwelling. Lucenda writes two short letters asking Arnalte to stop harassing her. At first, Lucenda says, she considered not writing at all: ‘ ¡Oh cuánto llegar la mano [a]l papel rehusé! (Oh how I refused to put hand to paper!)' ${ }^{34}$ Lucenda knows that writing to a man, even for this purpose, places her reputation at risk: 'Cata que cuando las tales vitorias los hombres pregonan, de la honra de las mujeres fazen justicia (See that when men boast of such victories, they put women's honor on trial)' ${ }^{35}$ As Janet Altman explains in reference to the French epistolary novel, female correspondents' efforts to defend themselves with letters often fail: 'Whereas the seducer regards the letter as his arm for overcoming the barrier between him and his lady, the lady paradoxically regards the letter 
as an extension of this barrier, as her weapon of protection. ${ }^{36}$ Lucenda's second letter offers Arnalte a contrabto (contract), agreeing to let him kiss her hands only if thereafter he ends his pursuit. ${ }^{37}$ The story ends in disaster when Arnalte breaks the contract. Lucenda marries Elierso, Arnalte kills him in a duel, and Lucenda flees to a convent in order to escape from her unwanted suitor. Lucenda's literacy does not aid her: whether she writes or remains silent, she cannot control Arnalte.

In San Pedro's La cárcel de amor, Laureola's letters evoke the same semantic fields as Lucenda's. Laureola explains her compassion for Leriano as the repayment of a debt: 'Más te escrivo por redemir tu vida que por satisfacer tu deseo. Mas, triste de mí, que este descargo solamente aprovecha para complir conmigo (I write you to redeem your life rather than to satisfy your desire. But, alas, this discharge of debt will only serve to bring an end to me)'. The words redimir ('redeem'), satisfacer ('satisfy'), descargo ('discharge'), and complir ('fulfill' or 'end') employ economic metaphors for love. In further connection to Lucenda, Laureola asks Leriano in one of the letters to preserve her fama or reputation..$^{8}$ Emily Francomano writes that for the characters of La cárcel de amor, these letters are indeed legal contracts: 'The characters see the creation of these written documents as both dangerous and binding'. ${ }^{39}$ As in Arnalte y Lucenda, however, the contract fails to protect the interested parties. Laureola can be traded for Leriano, or Leriano for Laureola, but only one can survive. Almost immediately upon Leriano's exit from the allegorical prison of love, Laureola's father confines her to a physical prison. Laureola pays her sentimental debt to Leriano with the coin of reputation: 'Remedié como inocente y pago como culpada (I redeemed as an innocent person and paid as a guilty one)'. ${ }^{40}$ The language of payment and remediation speaks to Laureola's fraught position as, at once, señora of courtly love and subject to the king, her father. She shares this double bind with Oriana of Amadis de Gaula and Cervantes's Luscinda. Yet Luscinda, with her combination of strategies, does eventually prevail over her father, Cardenio, and Fernando, though not without difficulty.

In the Cervantine episode, as in the San Pedro novellas, this difficulty arises when men refuse to take women's words at face value, instead interpreting the situation according to stereotype, dubious physical signs, or 
their own wishes. Luscinda responds to this problem by exteriorizing her emotions in a dramatic tableau. Her suicide attempt, real or feigned, is an extreme measure that gives male spectators the emotional display they expect from a woman. Chapter One discussed the ways in which Ovid's Heroides, a mutual source for the chivalric and sentimental traditions, mapped women's emotions onto specific, often sexualized body parts. Ovid's female epistle writers rend their hair and cheeks and describe tear-stained faces. In Amadis de Gaula, both men and women manifest emotion in the body. The sentimental tradition takes the embodiment of emotion one step further, as men actively read women's bodies for physical signs of emotion or deception.

In La cárcel de amor, the auctor ('author'), who plays messenger to the lovers, places greater faith in physical cues than Laureola's words. When Laureola makes an angry reply to Leriano's request, the auctor searches her face for a different response: 'Hallava en sus apariencias más causa para osar que razón para temer (I found in her appearance more cause for boldness than fear)..$^{41}$ The auctor feels certain that Laureola feigns sickness as a cover for love: 'Más vezes se quexava de estar mal por huir los plazeres. Cuando era vista, fengía algund dolor; cuando la dexavan, dava grandes sospiros (Many times she complained of feeling ill to flee from pleasures. When she was seen in public, she feigned some pain; when they left her alone, she heaved great sighs)'. ${ }^{2}$ Yet the change in Laureola's appearance might well be due to concern for her reputation, not love. In her letter, Laureola uses embodied language to express fear: 'Con este miedo, la mano en el papel, puse el coraçón en el cielo (With this fear, and with my hand on the paper, I committed my heart to heaven). ${ }^{43}$ The body, as a set of signs, is even more inscrutable than the written word, and yet men in the sentimental tradition are always confident that they can read it.

Having failed to transmit their point of view, San Pedro's Lucenda and Laureola have recourse to silence. Luscinda, in contrast, attempts to capitalize on the ways in which men read women. Luscinda's third letter, never quoted in text, is not a real communication, but a prop in a one-woman play that brings together the imitation of several literary sources. During the betrothal ceremony to Fernando, Luscinda shows Cardenio the emotion he expects, despair taken to the point of self-sacrifice. Luscinda's feeble attempt to stab herself recalls the tragic ending of 'Pyramus and 
Thisbe', Amadís's and Oriana's allusions to death in their letter and ballad, and legendary Roman matron Lucretia's honor-preserving suicide. The letter tucked into the bodice of Luscinda's gown, meanwhile, discloses her precontract with Cardenio and her desire to end her life. I agree with David Quint that Luscinda's gesture toward self-harm is only for show, as it bears a close resemblance to Camila's explicitly fake suicide attempt in El curioso impertinente. ${ }^{44}$ Luscinda has thus set up this tableau and placed her written words in a setting in which they will be read against the signs of her body. She appears to know how men read women, and she exploits those stereotypes. Here, as with the earlier letters, Luscinda's cleverness as an adapter of intertexts gives her quasi-authorial powers.

Given the deliberate staging of the suicide attempt, the fable at its center, that of Roman matron Lucretia, bears further examination. Though Luscinda does not utter the word 'Lucretia', her double, Camila, does, referencing the exemplary figure in her staging of the same trope. ${ }^{45}$ Lucretia, the wife of a Roman official, was raped by Tarquin and then committed suicide to expunge her family's honor. Livy relates the story as an illustration of the chastity and fortitude of Roman women..$^{46}$ As Pamela Benson points out, Lucretia was a popular persona in books of exempla like Boccaccio's $D e$ Mulieribus Claris. Her story speaks to women's reputation in two ways. Tarquin becomes determined to rape her because of her reputation for chastity and wifely devotion, illustrating that for women, any kind of fame-even positive fame - can be dangerous. ${ }^{47}$ More obviously, the story illustrates the lengths to which women are expected to go to defend their core virtue. Lucretia earns readers' sympathy because her response to circumstance is so extreme. By evoking this ancient persona, Luscinda connects her own story not to the tawdry world of chivalric or sentimental fiction, but to the gravitas of the classical exemplum, demonstrating to those present that she is innocent of wrongdoing. Remote, exaggerated models like Lucretia proved difficult for medieval and early modern women to follow. ${ }^{48}$ For Luscinda, as for Camila in El curioso impertinente, a feigned suicide attempt is an attempt at compromise: she wishes to earn the credit for self-martyrdom without actually dying. 
Though Lucretia is the name most strongly associated with an honorrelated suicide, Ovid's Heroides, another likely reading material for Luscinda, provides a secondary model that emphasizes women's capacity for revenge. One of Ovid's female letter writers is the bitter, raving Dido, who commits suicide upon being abandoned by Aeneas. Whether Luscinda is more like Lucretia or more like Dido depends on whom she feels has wronged her more deeply; is it Fernando, with his misplaced lust, or is it Cardenio, in his lukewarm treatment of the woman he claims to love? In a secret meeting at her window, Luscinda indicates that Cardenio is the real target of her performance, telling him:

Procura hallarte presente a este sacrificio, el cual si no pudiere ser estorbado de mis razones, una daga llevo escondida que podrá estorbar más determinadas fuerzas, dando fin a mi vida y principio a que conozcas la voluntad que te he tenido y tengo.

(Try to be present at the sacrifice, which, since it could not be prevented by my words, my hidden dagger, which could deter even more determined forces, will put an end to my life and a beginning to your knowledge of the love that I have had and still have for you.) ${ }^{49}$

Luscinda insists that Cardenio spy on the betrothal ceremony. If the real target of Luscinda's performance were Fernando, Cardenio's presence would not be required. Fernando, moreover, can learn nothing he does not already know from Luscinda's suicide; Cardenio will learn the depth and sincerity of Luscinda's love, which he might have gleaned from the letters had he been willing to pay attention to a woman's words.

As he watches the ceremony through a window, Cardenio expects to see physical violence but instead encounters verbal violence in the 'sí quiero (yes, I do)' with which Luscinda gives her consent to marry Fernando. ${ }^{50}$ If Cardenio is in fact the target of the suicidal tableau, the sí could be meant to hurt him just as Dido's coldness wounds Aeneas when she encounters him in the underworld in Book VI of Virgil's Aeneid. ${ }^{{ }^{1}} \mathrm{~A}$ jealous Cardenio watches as Luscinda faints, prompting her mother to loosen the girl's gown and reveal the dagger and the letter. Cardenio notices only the letter: 'Se descubrió en él un papel cerrado, que don Fernando tomó luego y se le puso

49 Cervantes Saavedra, Don Quijote, I, 27; 337; Cervantes Saavedra, Don Quixote, 223-24.

50 Cervantes Saavedra, Don Quijote, I, 27; 339; Cervantes Saavedra, Don Quixote, 223.

$5^{1}$ According to Michael McGaha, the Aeneid is one of the most important sources for Don Quixote Parts I and II. See 'Cervantes and Virgil', 34-35. 
a leer [...] y se puso la mano en la mejilla, con muestras de hombre muy pensativo (A sealed letter was discovered, which Don Fernando immediately took and began to read [...] when he finished reading it, he sat on a chair and rested his cheek in his hand, like a man lost in thought). ${ }^{52}$ Previously, Fernando spied on Cardenio and Luscinda's correspondence, but in a typical Cervantine reversal, Cardenio reads Fernando's face as he reads the letter.

Luscinda's letter does not have the desired effect on Cardenio because he does not stay for the entire performance. In Dorotea's account of the same event, which she did not witness, the reader learns that the dagger was indeed tucked into Luscinda's clothing and that Fernando attempted to kill her with it. ${ }^{33}$ We also learn that Fernando did not heed Luscinda's words. After the failed betrothal, he abducted her from her convent refuge, presumably to renew his plan to force her to marry him. Luscinda's attempts to manipulate men through literary imitation go wrong because her male interlocutors misunderstand them. Cardenio and Fernando witness the performance but ignore what they see. Dorotea, however, shares Luscinda's reading habits, and as an interpreter of Luscinda's performance and collaborator after the fact, she becomes the key to Cardenio and Luscinda's reconciliation. During her conversation with Cardenio, she plays the messenger, transmitting the content of Luscinda's third letter to Cardenio and corroborating Luscinda's suicide plan. Dorotea, a capable supporting actress, provides a logical excuse for Luscinda's behavior: 'Si había dado el sí a don Fernando, fue por no salir de la obediencia de sus padres (If she had agreed to marry Don Fernando, it was in order not to disobey her parents)'. ${ }^{54}$ To add to the ironies of this episode, Cardenio considers the gossip Dorotea retells a more authoritative source than the testimony of his own eyes. Cervantes gives no indication as to which version is true, emphasizing the importance of stories, including those told by women, in shaping the reality of the diegetic world.

\section{Dorotea and the Performance of Chivalry}

Like Luscinda, Dorotea has a problem caused primarily by Fernando and resolves it through playing a number of literary roles, many of them informed by chivalry. Dorotea seems at first to be a damsel in distress, but she also plays a messenger, a princess, and an enchantress. The tacit cooperation 
between Luscinda and Dorotea continues when the characters converge at Juan Palomeque's inn. Luscinda speaks first in this scene, calling Cardenio her verdadero esposo ('true husband'), but then defers to Dorotea, who puts on a show that solves the problems of both women. ${ }^{55}$ In Dorotea, Cervantes collects the chivalric roles available to women and allows the character to play them to her advantage. Though Luscinda also attempted to manipulate men through literary models, her success was incomplete. It is as though the two women have written two halves of a chivalric comedia, with Dorotea, the most astute reader of all, performing the final act.

Cervantes introduces Dorotea in Sierra Morena, placing her in the symbolic wilderness where Cardenio and Don Quixote practice their lovemadness. This is also the location where La cárcel de amor began and is thus the literal and figurative crossroads of the sentimental novel and chivalric romance. Dorotea, dressed as a shepherd boy, recites a long monologue recounting her life history to the barber, the priest, and Cardenio that is itself rich in literary allusion. Stanislav Zimic observes that Dorotea's confession to a trio of strangers echoes Heliodorus. ${ }^{6}$ Armando Villamandos compares Dorotea's story to the Italianate novella and cape-and-sword plays. ${ }^{57}$ Both Villamandos and Christine Garst-Santos find references to Juan Luis Vives's The Education of a Christian Woman (1523) in Dorotea's representation of herself. ${ }^{8}$ Garst-Santos also mentions Fray Luis de León's La perfecta casada (The Perfect Wife, 1583) as a touchstone for Dorotea's description of her family life. ${ }^{59}$ Like Luscinda, Dorotea takes a combinatory approach to citation, and she fuses tropes from each of these genres to her imitation of chivalry.

Dorotea joins many other quixotic figures in the novel, including Luscinda, in her indulgence in entertainment-oriented literature. Both characters imitate what they read, but Luscinda embodies chivalry's passive roles for women, while Dorotea exhibits the agency and penchant for cross-dressing of chivalry's warrior women. Each of Dorotea's phrases is calculated to capitalize on her interlocutors' attitudes toward women, chivalry, and reading. For example, Dorotea initially admits only to reading 'algún libro devoto (a book of devotions)', but once the priest presents his plan of entrapping Don Quixote with a mock quest, Dorotea reveals herself to be a fond reader of chivalric romance. ${ }^{60}$ Dorotea's lie of omission reveals her

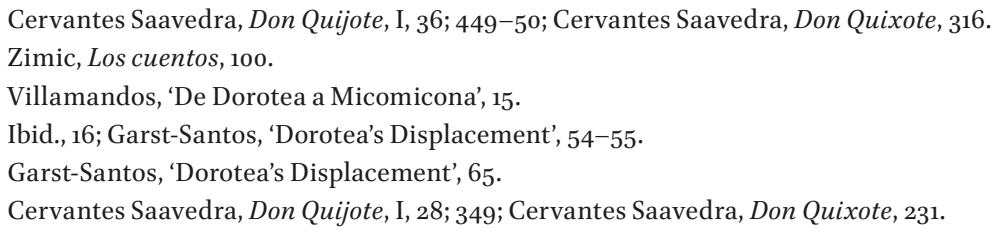


awareness of the humanist prejudice against chivalric reading. Throughout the episodes in which she appears, Dorotea performs her identities for others. She is alternately an ideal daughter, a helpless princess, and a nononsense seeker of revenge, depending on who is listening. The stories Dorotea tells about herself constitute what Judith Butler would describe as a 'social performance' of gender tropes rather than a reflection of qualities inherent to the character. ${ }^{61}$ Dorotea is capable of living for weeks dressed as a man and defending herself from threats by verbal or physical means. The narratives she offers her male interlocutors are a particularly useful form of self-protection, and her autobiography likely owes as much to literature in its construction as does her more overt imitation of chivalry.

Dorotea brings the powers of the reader to bear on all the identities she represents, but she must tread carefully as she reveals that reading to her interlocutors. Most early modern moralists considered some amount of reading to be acceptable for women, as long as they did not stray into the entertainment-oriented genres that encouraged idleness and vice. Erasmus praises educated women, including Catherine of Aragon, but he decries fictional reading for both genders. ${ }^{62}$ Juan Luis Vives writes that women should restrict their reading to devotional books and the Scriptures. ${ }^{6}$ Fray Luis laments women's fondness for 'el leer en los libros de caballerías, y [el] traer el soneto y la canción en el seno, y [el] billete (reading books of chivalry, carrying sonnets and songs tucked in their bodices, and letters)'.64 Pedro de Luján, who wrote a romance of chivalry, Silves de la Selva (1546), and a conduct book, Coloquios matrimoniales (Colloquies on Matrimony, 1550), uses the character Doroctea, a literate woman of the bourgeoisie 'asaz instructa en la lengua latina (very learned in Latin)', to inform women that they should read only devotional books, Scriptures, and history. ${ }^{65}$ Cervantes's Dorotea, whose name suggests a possible connection to Luján's character, is careful not to stray from humanist recommendations until the priest's comment reveals that it is safe to do so.

Dorotea in this passage suggests herself as the opposite of an idealized female figure in Don Quixote's orbit, the illiterate Dulcinea. The gulf between the two characters reveals the degree to which women's literacy could be considered controversial. In the very section of the work in which Luscinda

61 Butler, Gender Trouble, 180.

62 Sowards, 'Erasmus and the Education of Women', 80.

63 Vives, Education of a Christian Woman, 71.

64 Fray Luis de León, La Perfecta Casada, 8o; Vives, Education of a Christian Woman, 78.

65 Luján, Coloquios matrimoniales, 19, $15^{2}$. 
and Dorotea make use of their literary habits, Don Quixote writes a letter to Dulcinea but comments that 'Dulcinea no sabe escribir ni leer (Dulcinea does not know how to read or write) ${ }^{6}{ }^{6}$ It is unclear whether Dulcinea cannot read because her model, the village girl Aldonza Lorenzo, comes from a social class with a low level of literacy, or whether she cannot read because Don Quixote considers illiteracy a desirable quality in a woman. In this same passage, Don Quixote mentions the encerramiento (seclusion) in which Dulcinea's parents brought her up, a term that would apply to Luscinda's upbringing and that actually surfaces in Dorotea's description of her youth. ${ }^{67}$ Cervantes may mean to prompt readers to compare the three women.

In fact, Cervantes may even mean to illustrate that literacy is a lesser evil than ignorance. While Dulcinea's literacy debatably places her at a moral advantage, it is also inconvenient to the point that it makes communication with Quixote impossible. If Dulcinea is to hear Quixote's missive, Sancho, the scribe, and the literate person who eventually reads it to her must learn her private business, which they might later use to harm her reputation. Sancho never does deliver the letter, but he tells Quixote an apocryphal story of doing so, and even he, an illiterate farmer, understands the risks a love letter read out loud would pose to a woman's reputation. Sancho's imaginary Dulcinea tears the letter into pieces, valuing privacy over communication. Dulcinea's illiteracy makes it impossible for her to conduct business of any kind across distance, which would have made an aristocratic or bourgeois woman's household duties more difficult to accomplish.

For Cervantes's Dorotea, as for other women of the emergent bourgeoisie, literacy provided not just instruction and entertainment but also an opportunity to contribute to the family's economic productivity. Dorotea manages her family's account books, oversees parts of the farm, and hires and fires servants, activities best paired with literacy and numeracy. ${ }^{68}$ For Garst-Santos, literacy is a fundamental part of 'the emergent virtue of hard work'. ${ }^{69}$ Cátedra and Rojo's study of women's wills from sixteenth-century Valladolid finds connections between book ownership and other professional activities for women, such as participating in a family business..$^{7^{0}}$ Dorotea uses the categories familiar from conduct books to describe her genteel employments and literary pursuits, but ultimately what emerges

66 Cervantes Saavedra, Don Quijote, I, 25; 311.

67 Ibid., I, 28; 349 .

68 Ibid.

69 Garst-Santos, 'Dorotea's Displacement', 59.

70 Cátedra and Rojo Vega, Bibliotecas y lecturas de mujeres, 36-39. 
is a portrait of a woman fully involved in her family's economic life who uses her learning to support that activity. The illiterate Dulcinea, whom Sancho depicts winnowing grain, can only participate in the family economy through physical labor. ${ }^{71}$

Dorotea's statement that she was brought up in cloister-like seclusion cannot be accurate, especially if she took an active role in managing the farm. ${ }^{72}$ Her parents do not appear to have restricted her reading material much either, and she has almost certainly read some of the same books as Luscinda. In further connection to her tacit partner, Dorotea has been under attack by Fernando, the same unscrupulous nobleman who preyed on Luscinda. Dorotea explains how, like Diego de San Pedro's Arnalte, Fernando pursued her in increasingly public ways, bribing her servants, playing music in the street at night, and sending infinite numbers of letters (billetes). ${ }^{73}$ Fernando's unwelcome letters, like Arnalte's and Leriano's, breach physical and emotional barriers. Unlike Lucenda, however, Dorotea chooses not to respond.

A lack of written response, unfortunately, proves to be no better defense than a letter of rejection. Fernando bribes his way into Dorotea's house and rapes her under pledge of matrimony. Anne J. Cruz remarks that early modern readers might well have blamed Dorotea for her own assault: 'Once a man transgressed a girl's protective barrier, she incurred the blame for leaving herself vulnerable to his attack'. ${ }^{74}$ To seek justice, Dorotea turns away from the conduct book and toward chivalric romance. When Dorotea narrates the crime to the priest, the barber, and Cardenio, she first describes Fernando as a caballero, a word that means both nobleman and knight, and argues that he has broken the social contract. Second, she reports that she asked Fernando to swear a pact of clandestine marriage, as many couples do in Iberian books of chivalry. ${ }^{75}$ Dorotea uses the language of the romance of chivalry to accomplish the goal of a sentimental novel-style letter, the preservation of her honor. Moreover, her narrative draws in Cardenio, the barber, and most importantly, the priest, as witnesses after the fact to the clandestine marriage, a technique that will later help her cement its legality.

Hierarchy, one of the main principles of chivalric romance, is key to Dorotea's narrative, and she represents the relationship between herself and 
Fernando as essentially feudal. She begins the story with 'en esta Andalucía hay un lugar de quien toma título un duque (here in Andalucía there is a place from which a duke takes his title)', not with herself or with her family, because this is a story about lords who betray their vassals. ${ }^{76}$ The phrase 'un lugar de' recalls the opening lines of the novel and Don Quixote's own obscure hometown, suggesting a comparison between Dorotea and the mad knight and reinforcing the idea that, in her narrative, Dorotea is imitating chivalric romance. Dorotea's geographic reference also recalls the linkage of character and place common in the romance of chivalry, as in the names Amadís de Gaula, Belianís de Grecia, Palmerín de Inglaterra, Lancelot du Lac, and Cristalián de España. The names Don Quixote de la Mancha and Dulcinea del Toboso parody this trope. Dorotea foregrounds Fernando's origin to show that he disrupts the social contract, a serious breach either in the romance of chivalry or in the world of Don Quixote.

Fernando at once transgresses against the chivalric code and the more verisimilar concept of noblesse oblige. Maurice Keen writes that chivalry requires of the knight both hereditary nobility and personal virtues including prowess, loyalty, generosity, courtesy, and frankness. ${ }^{77}$ The code of chivalry reinforces existing hierarchies, and the knight owes service to those above and below. The lord-vassal relationship is a cornerstone of chivalric literature: knights owe fealty to their lords and magnanimity to their vassals. Don Quixote's promise to reward Sancho with an island reflects the idea that knights must share the spoils of victory with their retainers. The relationship between Dorotea and Fernando's families is one of unequal power but mutual responsibility, and it should be a relationship of mutual respect. Dorotea makes explicit their contract: 'Tu vasalla soy, pero no tu esclava; ni tiene ni debe tener imperio la nobleza de tu sangre para deshonrar y tener en poco la humildad de la mía (I am your vassal, but not your slave; the nobility of your blood does not have nor should it have the power to dishonor and scorn the humbleness of mine) $\cdot .^{8}$ Dorotea argues that relative to their station, her family is just as worthy of respect as Fernando's.

In chivalric narratives, exalted lineage usually correlates with virtue. Jesús Rodríguez Velasco, however, has observed what he terms the 'chivalric fable', a counter-discourse of personal merit in which knights make their own way in the world, independent of their families. ${ }^{79}$ Rodríguez Velasco 
also notes that the late medieval bourgeoisie employed the discourse of chivalry against an entrenched nobility: 'Certain bourgeois groups that accrued a growing economic importance set up new spheres of power by invoking and reinventing discourses on chivalry'. ${ }^{80}$ Dorotea seems to favor social mobility in accordance with virtue and, in connection, punishment for those of privileged lineage who defy the chivalry code. Dorotea argues that Fernando has transgressed against his noble blood, revealing that blood to be worthless in the first place. Her narrative also leaves open the possibility of new entry to the nobility. Dorotea's own parents are in the process of climbing the social ladder:

Ellos, en fin, son labradores, gente llana, sin mezcla de alguna raza mal sonante, y como suele decirse, cristianos viejos ranciosos; pero tan ricos, que su riqueza y magnífico trato les va poco a poco adquiriendo nombre de hidalgos, $\mathrm{y}$ aun de caballeros

(They are, in short, farmers, simple people with no mixture of any objectionable races, what are called the Oldest of Old Christians, but so rich that their wealth and luxurious way of life are slowly gaining for them the name of gentlefolk, even of nobility) ${ }^{81}$

In one sentence, Dorotea transforms her parents from humble farmers to old Christians to caballeros, the same word she applies to Fernando's family. She suggests, moreover, that her parents are more truly noble than Fernando. The word magnifico ('magnificent') suggests not just wealth and luxury but generosity offered to those below on the social ladder, who ideally should exist in a relationship of mutual respect and benefit with their betters.

While wealth and hard work have improved the standing of Dorotea's family, marriage to the son of a Duke would offer greater social prominence. Though the prospect of a marriage between Dorotea and her abuser might seem abhorrent to twenty-first-century readers, Cruz notes that 'life in a convent or marriage to the assailant' would have been the only available means of restoring honor after a rape in early modern Spain. ${ }^{82}$ To lay the groundwork for her social redemption, Dorotea convinces Fernando to swear a pact of clandestine marriage that resembles the secret oaths of Perión and Elisena and Amadís and Oriana in Amadís de Gaula. Dorotea echoes Oriana when she declares to Fernando that she would freely grant the sexual favors 
he seeks by violence to a legitimate husband. ${ }^{83}$ Oriana, though consenting to sex willingly, makes a similar statement during her first sexual encounter with Amadís: 'Yo haré lo que queréis, y vos hazed como, aunque aquí yerro y pecado parezca, no lo sea ante Dios (I will do what you wish, and you must make it so that, even though it seems to be error and sin, it is not so in God's eyes), ${ }^{84}$ Dorotea's diction is likewise religious: 'Para con Dios seré su esposa (In the sight of God I will be his wife), ${ }^{85}$ Dorotea shares with her chivalric sources the notion of marriage as a spiritual, private matter dependent on consent and requiring no familial or ecclesiastical supervision.

Yet there are differences in the two scenes, the first of which concerns hierarchical relationships. Dorotea refers to Fernando as señor ('lord'), while Oriana calls Amadís the more affectionate amigo ('friend'). Amadís, meanwhile, gallantly refers to Oriana as his señora ('lady'), granting her symbolic power. The second deviation concerns the legality of the private marriage contract. Though the clandestine marriages in Amadis have an ambiguous legal status and are later reinforced through public wedding celebrations, the mid-fourteenth century, when the primitive Amadis emerged, would have been more likely to support a clandestine marriage than post-Council of Trent Spain.

In this episode, Cervantes references the centuries-long debate in Europe over who has the power to make marriage contracts. The needs of individuals who wish to contract marriages of choice conflict with the needs of families, who increasingly in the early modern era assert their right to choose marriage partners for their children. Yet Christian thinkers and humanists pay lip service to consent, as demonstrated in Pedro de Luján's statement 'por solo el consentimiento se contrae el matrimonio (matrimony may only be contracted by consent), ${ }^{86}$ Michael Harney writes that Iberian chivalric romance consistently debated the issue: 'The principal conflict in the narratives occurs between those who regard arrangement of marriage as a patriarchal entitlement and those who [...] glorify marriage as an emotional and sexual bond between two individuals. ${ }^{87}$ In medieval Iberia, as Harney explains, the Church took the side of consent, while wealthy families emphasized the needs of kin groups over those of individuals. ${ }^{88}$ The Siete Partidas (Seven-Part Code) of Alfonso $\mathrm{X}$ upheld the validity of marriages contracted on consent

83 Cervantes Saavedra, Don Quijote, I, 28; 354.

84 Rodríguez de Montalvo, Amadís de Gaula, I: 573.

85 Cervantes Saavedra, Don Quijote, I, 28; 353; Cervantes Saavedra, Don Quixote, 235.

86 Luján, Coloquios matrimoniales, 40.

87 Harney, Kinship, 105.

88 Ibid., 113 . 
alone, especially if those marriages were consummated. ${ }^{89}$ However, medieval legal codes also recognized the difficulties such marriages could present. ${ }^{90}$ Anne J. Cruz explains that 'although valid, clandestine marriages offered no means of ensuring consent by both parties, since there were no witnesses and, without banns posted or read, no way to investigate impediments'. ${ }^{11}$ In 1563 , the Council of Trent invalidated private marriages. ${ }^{92}$

Iberian chivalric romance, with some exceptions, takes a sympathetic view of characters who engage in clandestine marriage. In Cervantes the situation is more ambivalent, and the question is not resolved until Fernando confirms Dorotea's version of events in public. The measures Dorotea takes to solemnize the marriage, however, echo chivalric romance. In both Amadis and Don Quixote, there are witnesses to the promise: Dorotea's unnamed maid and Elisena's maid Darioleta. An object with symbolic significance also takes part. Darioleta asks Perión to swear on his sword to marry Elisena, and for Fernando and Dorotea, an image of the Virgin Mary serves the same purpose. ${ }^{93}$ Rings change hands in both clandestine marriages in Amadis; Perión gives Elisena his ring, and Oriana gives Amadís her ring. Fernando, similarly, removes a ring from his hand at the conclusion of their meeting and gives it to Dorotea. These rings are pledges of sentiment, but they are not equivalent to modern wedding rings. In chivalric romance, such tokens are meant to identify the giver and receiver to each other. For example, they can be sent with letters to certify the message's authenticity or given to an illegitimate child to certify his or her paternity.

In order to make her marriage to Fernando a legal reality at the turn of the seventeenth century, Dorotea must engage in a second chivalric imitation. Dorotea volunteers to play the doncella menesterosa ('damsel in distress') in order to assist the priest and barber in extracting Don Quixote from the wilderness. She changes from her shepherd's attire into her own clothes and asks Don Quixote to follow her until she releases him. Anne J. Cruz remarks that 'as a marvelously ingenious storyteller, [Dorotea] spins a delightful novel of chivalry that allegorizes her own amatory experiences'. ${ }^{4}$ For me, Dorotea's performance as Micomicona is not merely an allegory, but a deliberate attempt to persuade her interlocutors. Yet at first, Dorotea and the priest struggle for authorship. Micomicona was the priest's idea, and he adds details that mock 
Dorotea both implicitly and explicitly. For Laura Gorfkle, when Dorotea imitates the discourse of chivalry, 'she emphasizes her neediness and her dependence on male authority'. ${ }^{95}$ As Gorfkle observes, the romance of chivalry often places women in dependent positions. However, chivalric romance also contains many female chivalric characters who disobey convention-not just the famous cross-dressed female knights, but also certain princesses, servants, and enchantresses, whose adventures are on display in the first two chapters of this book. Dorotea seizes control over the Micomicona fiction in order to exploit chivalry's transformative potential. By the episode's conclusion, three male readers of chivalry-Cardenio, the priest, and Don Quixote-have pledged their support for her version of the character.

The priest introduces Micomicona to Sancho as a Guinean princess who has come to Spain to ask Don Quixote 'que le desfaga un tuerto o agravio que un mal gigante le tiene fecho (that he right a wrong or correct an injustice done to her by an evil giant)'. ${ }^{6}$ The priest's take on the romance of chivalry shows inexpert knowledge of the genre. He describes the apocryphal Micomicona as the heiress of her kingdom 'por línea recta del varón (by direct male line)' when this is impossible, as she would be a female inheritor. The repetitive phrase 'tuerto o agravio' could mean anything or nothing. The term mal gigante suggests the most banal of chivalric villains. According to Walter Stephens, giants in medieval literature are evil by nature, and their malice has little psychological motive. ${ }^{97}$ For Jeffrey Jerome Cohen, the giant is a creature of pure appetite. ${ }^{98}$ The giant of the priest's imagination has no specific motivation; he is merely evil in a generic way.

The priest imagines a princess who is likewise deviant from the ideal in a generic, superficial way. She hails from Guinea, and the white skin of the woman who incarnates her suggests a connection to Chariclea and Clorinda, the white-skinned African princesses in Heliodorus and Torquato Tasso respectively. The details of Micomicona's apocryphal biography reference color-based racism and the African slave trade. Sancho imagines enslaving the country's black inhabitants and turning them, literally, into money: 'Por negros que sean, los he de volver blancos o amarillos (No matter how black they are, I'll turn them white and yellow)'. ${ }^{99}$ I would argue that the details of the priest's story express not only racism, but also the priest's unfavorable

96 Cervantes Saavedra, Don Quijote, I, 29; 362; Cervantes Saavedra, Don Quixote, 242.

97 Stephens, Giants in Those Days, 3.

98 Cohen, OfGiants, 38 .

99 Cervantes Saavedra, Don Quijote, I, 29; 366; Cervantes Saavedra, Don Quixote, 245. 
opinion of the woman who plays Micomicona. The salient idea behind Micomicona's origin is her failure to conform to the white Christian ideal. In Luján's Coloquios matrimoniales, the character Eulalia comments: 'Más quisiera haberme casado con un negro de Guinea cuando me casé con mi marido (I would have rather married a black man from Guinea than my husband)'. ${ }^{100}$ The reference to Guinea indicates that the priest considers Dorotea undesirable.

The name 'Micomicona' reinforces this notion, as all its potential meanings are misogynist. For modern readers, mico suggests a connection to female genitals, though this interpretation is likely an anachronism. ${ }^{101}$ For the early modern context, Covarrubias defines mico as 'una especie de mona, pero con cola, y de faciones, y talle más jarifo (a type of monkey, but with a more lovely tail, features, and figure)'. ${ }^{102}$ In Iberian romance, Montalvo and Feliciano de Silva use mono ('monkey') and ximio ('primate') as insults, usually as markers of ugliness. Covarrubias mentions in his definition of mona that sailors often mistake apes for human beings in their travels. ${ }^{103}$ In the Sergas de Esplandián, monkeys both imitate and transgress against humans. Two large apes steal helmets from Christian knights and repeatedly 'poníanlos en las cabezas y quitávanlos (put them on their heads and take them off).' ${ }^{104}$ Carlos Sainz de la Maza reads this detail as a 'comic interlude' but also notes that in the medieval bestiary tradition, monkeys symbolize the devil. ${ }^{105}$ In connection, the ugly dwarf Ximiaca of Feliciano de Silva's Florisel III, whose name means monkey-like, mimics chivalric femininity in a perverse manner. This minor character elicits laughter as she promises to release the Christian hero from prison in return for sexual favors. ${ }^{106} \mathrm{By}$ naming Dorotea 'Micomicona', the priest reads her as worthy of mockery and guilty of sin.

Many readers and critics join the priest in his unsympathetic interpretation of Dorotea's rape narrative. Anne J. Cruz notes a sexist trend in criticism on the episode: 'Nothing that Dorotea says or does convinces [scholars] that she is anything but a vindictive virago hiding under the guise of a meek,

100 Luján, Coloquios matrimoniales, 48.

101 For the sexual connotation of 'mico', see Cruz, 'Dorotea's Revenge', 617; Casalduero, Sentido y forma del Quijote, 148; Márquez Villanueva, Personajes y temas del Quijote, 21.

102 Covarrubias Horozco, Tesoro de la lengua castellana, $548 \mathrm{v}$.

103 Ibid., $553 \mathrm{v}$.

104 Rodríguez de Montalvo, Las sergas de Esplandián, 268.

105 Ibid., 268 n. 178.

106 Silva, Florisel de Niquea (Parte III), 80. 
guileless victim.' ${ }^{107}$ Márquez Villanueva, for example, writes that Dorotea is immodest. ${ }^{108}$ Harry Vélez Quiñones remarks the 'regrettably misogynistic' current in Robert M. Flores's reading of the episode, which characterizes Dorotea as damaged goods, unworthy of becoming Fernando's legal wife. ${ }^{109}$ Robert Hathaway emphasizes Dorotea's capacity for deception. ${ }^{110}$ For many critics, Dorotea is a seductress suspicious in her behavior and rhetoric. The priest's story of Micomicona amplifies Dorotea's potential negative qualities, and for Augustin Redondo, Micomicona might truly be larger than life. He finds in the name 'Micomicón' a potential connection to the chivalric giant based on the phonetic similarity between Micomicones and Patagones, the famous giants of Primaleón. ${ }^{111}$ Redondo speculates that Micomicón might mean 'giant monkey'. Though Redondo finds utopian potential in the suggestion, it bears mentioning that a land of giants might also be a region of evil, and that a giant monkey would be an undesirable bride for most humans.

The priest, the worst acting partner possible for the improvisational comedia built around Micomicona, offers Dorotea an origin story that promises humiliation. However, using her extensive knowledge of chivalry, she redirects Micomicona's biography to earn her interlocutors' sympathy. Dorotea asks Quixote for a favor according to solemn chivalric ritual:

De aquí no me levantaré ¡oh valeroso y esforzado caballero! fasta que la vuestra bondad y cortesía me otorgue un don, el cual redundará en honra y prez de vuestra persona y en pro de la más desconsolada y agraviada doncella que el sol ha visto.

(I shall not rise up from this place, $\mathrm{O}$ valiant and brave knight, until thy goodness and courtesy grant me a boon, which will redound to the honor and renown of thy person and the benefit of the most disconsolate and aggrieved damsel e'er seen by the sun. $)^{112}$

Dorotea's expansive syntax and linguistic archaism reveal knowledge of the form and content of the romance of chivalry. She defines the knight's identity through the virtues of valor ('bravery') and esfuerzo ('prowess') and

107 Cruz, 'Dorotea's Revenge', 626.

108 Márquez Villanueva, Personajes y temas del Quijote, $25^{-26}$.

109 Vélez Quiñones, 'Barefoot and Fallen', 282; Flores, ‘¿Cómo iban a terminar los amoríos de Dorotea y don Fernando?', 463 .

110 Hathaway, 'Dorotea, or the Narrators' Arts', 112.

111 Redondo, Otra manera de leer el Quijote, 365.

112 Cervantes Saavedra, Don Quijote, I, 29; 364. 
acknowledges his quest for honra ('honor') and prez ('reknown'). Her kneeling posture and her state of mind, described as desconsolada ('disconsolate') and agraviada ('aggrieved'), identify her as a worthy suppliant. After Quixote vows to comply with her request, Dorotea evokes a second chivalric motif by making her favor open-ended, asking that he follow her until she has been avenged. ${ }^{113}$ The don contraignant ('blind promise'), a familiar chivalric motif, places the knight in Micomicona's power and gives her a means to abuse him, should she wish to. In connection, those that remain with Don Quixote, including the priest, now must follow her lead.

Dorotea's favor draws on Torquato Tasso's Armida as a model, as Frederick de Armas and Pedro Ruiz Pérez have noted. ${ }^{114}$ This citation reveals that more is at stake in this episode than giants and princesses. Tasso, like Cervantes, tried to reconcile chivalry and verisimilitude, and through Dorotea, Cervantes reiterates and reconstructs Tasso's theory of the marvelous. In Canto IV of Tasso's Gerusalemme Liberata (Jerusalem Delivered, 1581), the Saracen sorceress Armida requests help under false pretenses from Godfrey and his soldiers, hoping to thin the Christian ranks by convincing men to abandon the battlefield. Armida introduces herself as a princess, the daughter of Arbilan and Chariclia of Damascus. The name Chariclia invokes the protagonist of Heliodorus's Ethiopian History, the white-skinned princess Chariclea from North Africa, whose biography also resembles Micomicona's. According to Armida, her parents died, leaving her to the mercy of an uncle who usurped power in her kingdom and urged her to marry her objectionable cousin. Though not a giant, this man has a 'misshapen' exterior, 'base mind', 'proud heart', and 'greedy and burning desires.' ${ }^{115}$ Some of the details Dorotea adds to the priest's Micomicona story, including her status as an orphan and the threat of unequal marriage to a partner who is psychologically but not physically monstrous, closely resemble Armida's story. Dorotea, not the priest, is the potential reader and imitator of Tasso.

It is possible that the invocation of Armida's deceitful request to Godfrey indicates that Dorotea's cause is not just. Ruiz Pérez describes Armida as 'the feminine image of evil, seduction, and deceit'. ${ }^{116}$ However, Dorotea's intentions are substantially different from those of the Saracen sorceress. Armida leads Christian soldiers away from holy war to a garden of false

113 Ibid., I, 365 .

114 De Armas, 'Cervantes and the Italian Renaissance', 44; Ruiz Pérez, 'La hipóstasis de Armida', 157 .

115 Tasso, Jerusalem Delivered, 4:46.

116 Ruiz Pérez, 'La hipóstasis de Armida', 157. 
delights. Dorotea wants to lead Don Quixote away from a wilderness where literary tropes and fantasies intersect, causing harm to those who indulge in them, including herself. Armida sickens her victims, but Dorotea leads Quixote toward sleep, food, and the recovery of his health.

Armida and Dorotea may have different moral polarities, but they resemble each other as figures of the meanings and uses of fiction. Critics have understood Armida as a crucial articulation point for Tasso's debate over the deceptive nature of fiction in Gerusalemme Liberata and Discorsi sul poema eroico (Discourses on the Heroic Poem, 1594). Tasso wrote the early portion of the discourses at the same time at which he composed his heroic poem, which he later revised as Gerusalemme Conquistata (Jerusalem Conquered) according to Aristotelian criteria for verisimilitude. For Tasso, the primary struggle concerns the dubious reputation of the marvelous, which existed both in the ancient epic he sought to imitate and in the romances of chivalry that influenced his depictions of knighthood and military action. Chivalric fiction itself is not immune to the preference for truth: books of chivalry, including Amadis de Gaula, often pretend to be histories. ${ }^{117}$ In the Italian context, epic poetry and chivalric romance are difficult to distinguish. Boiardo's Orlando Innamorato (Orlando in Love) and Ariosto's Orlando Furioso (The Frenzy of Orlando), both of which Tasso terms heroic poems, freely intermingle tropes from classical epic and chivalric romance.

Tasso, who looked to epic as his privileged model, developed a concept of the Christian marvelous in the Discorsi that sought to include fanciful motifs while observing Aristotelian rules. ${ }^{118}$ Tasso found the marvelous necessary to produce 'wonder' and 'delight', but cautioned that writers should ground it in verisimilitude:

The poet ought to attribute actions that far exceed human power to God, to his angels, or demons, or to those granted power by God or by demons, for example, saints, wizards, and fairies. Such actions, if considered in themselves, will seem marvelous; nay, they are commonly called miracles. But if regarded in terms of their agent's efficacy and power, they will seem verisimilar. ${ }^{119}$

117 Fogelquist, El Amadís y el género de la historia fingida, 6-9.

118 Forcione, Cervantes, Aristotle, and the Persiles, 40; Rhu, The Genesis of Tasso's Narrative Theory, 20.

119 Tasso, Discourses on the Heroic Poem, 38. 
Armida, as an enchantress, inhabits Tasso's space of dubious verisimilitude. For Lynn Enterline, she allegorizes and distorts Tasso's own narrative project. ${ }^{120}$ For Lawrence Rhu, Armida represents 'the temptation that lays traps for the affective faculty'.121 According to Tasso, it requires only a small suspension of disbelief to accept the idea that wizards and enchantresses can do magic. Armida thus suggests one way to reconcile the desire for the marvelous with the need for verisimilitude: sorceresses are inherently believable. ${ }^{122}$ Modern readers, however, are not likely to agree with Tasso on the relative realism of wizards and fairies. Cervantes's Dorotea poses a solution with greater longevity in the modern novel through the use of chivalry as a metaphor for 'real' life, rather than presenting chivalry as verisimilar in and of itself.

Like Tasso, Cervantes's canon of Toledo expresses ambivalence about fiction that announces itself as different from reality. It is possible that Cervantes had Tasso in mind when he developed the conversation between the canon and the priest in Don Quixote Part I. ${ }^{123}$ According to Anthony Cascardi, the conversation references the search in classical texts, especially Aristotle, for 'normative guidelines that could be used to regulate contemporary literary practice. ${ }^{124}$ Similarly, Forcione argues that Cervantes sought to reconcile the appealing features of medieval romance with the Aristotelian rules in vogue at the turn of the seventeenth century. ${ }^{125}$ The canon refers to romances of chivalry as harmful to the nation, criticizing them for heterogeneity, bad style, and lack of verisimilitude. ${ }^{126}$ This character is a failed chivalric writer, and perhaps his opinion indexes his frustration with his own inability to reconcile chivalry to the present moment. Yet neither the priest nor the canon, both vocal opponents of chivalry in Don Quixote Part I, can resist the powers of romance, and they listen attentively when Don Quixote tells his own story of the Caballero del Lago ('Knight of the Lake'), which contains a boiling lake and an enchanted palace made of gold. Don Quixote's take on the romance of chivalry may provide the wonder and delight Tasso sought, but it is Dorotea's version that reconciles the real and the fictional.

120 Enterline, The Tears of Narcissus, 115 .

121 Rhu, The Genesis of Tasso's Narrative Theory, $15^{8 .}$

122 Tasso, Discourses on the Heroic Poem, 14-15.

123 Forcione, Cervantes, Aristotle, and the Persiles, 30-35. Cervantes mentions Tasso and Gerusalemme Liberata in Persiles; Tasso appears painted in a panel depicting poets of the future.

124 Cascardi, Cervantes, Literature, and the Discourse of Politics, 43-44.

125 Forcione, Cervantes, Aristotle, and the Persiles, 12.

126 Cervantes Saavedra, Don Quijote, I, 47; 564. 
Micomicona's plight is not only Armida's - it is also Dorotea's own, drawn from her previous narration to the other characters. Critics generally agree that Dorotea reinterprets her personal misfortunes during her performance as Micomicona. David Quint observes that 'the reader sees the parallel between Dorotea's real-life situation and the chivalric scenario invented for the benefit of Don Quijote-Don Fernando is like a wicked giant, she is a genuine damsel-in-distress. ${ }^{127}$ John Jay Allen characterizes the meeting between Quixote and Dorotea as 'a confrontation between a mad knight playing the part of a mad knight and a damsel in distress playing a damsel in distress'. ${ }^{128}$ Ruth El Saffar states that 'as Micomicona, Dorotea repeats the role she played for the priest and barber'. ${ }^{129}$ For Quint, Allen, and El Saffar, the correspondence between appearance and reality are key to Dorotea's rendition of Micomicona, while for De Armas and Ruiz, literary imitation is the most important feature of the performance. For me, it is precisely the balance of imitation and verisimilitude that creates Dorotea's personality as an author-figure. While it is true that many stories about women in chivalric romance include predatory men or predatory giants, in my opinion, Dorotea bends the details of Armida's story toward her own biography in a way that is meant to be read as deliberate. As a result of this closure of the gap between literature and life, her story is more convincing to her listeners than Quixote's 'Caballero del Lago', which contains, coincidentally, a woman who is preternaturally silent.

Dorotea's most successful use of chivalry as metaphor occurs when she renders Micomicona's giant enemy an echo for Fernando. She gives the monster a name-Pandafilando de la Fosca Vista — and describes him to Don Quixote as a 'descomunal gigante, señor de una grande ínsula, que casi alinda con nuestro reino (monstrous giant, lord of a large island that almost touches our kingdom)'. ${ }^{130}$ Pandafilando's uncommonly large size and his geographical proximity to the kingdom of Micomicón reflect the lord-vassal relationship between Fernando and Dorotea's families. The term ínsula echoes Don Quixote's own promise to reward Sancho and gestures to the language of social class and obligation present in Dorotea's autobiographical narrative. Dorotea has primed her audience to see Fernando as evil and Dorotea as a victim who merits restitution.

127 Quint, Cervantes' Novel of Modern Times, 5 .

128 Allen, Don Quixote, Hero or Fool?, 69.

129 El Saffar, Beyond Fiction, 70.

130 Cervantes Saavedra, Don Quijote, I, 30; 373; Cervantes Saavedra, Don Quixote, 251. 
Dorotea's description of Pandafilando, moreover, clarifies that the nature of his monstrosity is psychological, not physical, placing her narrative more clearly in the territory of metaphor. His name seems to reference a deformity, but Dorotea explains that 'aunque tiene los ojos en su lugar y derechos, siempre mira al revés, como si fuese bizco, y esto lo hace él de maligno (although his eyes are in the correct place, he always looks the wrong way round, as if he were cross-eyed, and does this out of malice)'. ${ }^{11}$ Pandafilando's propensity to turn his head and stare reflects Fernando's sinister lust. In further connection to Dorotea, Micomicona resists the giant's advances because he represents an unequal marriage. Here Dorotea inverts the relative social positions of herself and her seducer; Pandafilando is too base a partner for Micomicona. Dorotea may be Fernando's economic inferior, but she is his superior in virtue. Micomicona flees Pandafilando's endiablada fuerza ('devilish power') to seek help in Spain, just as Dorotea fled her home to seek recognition of the clandestine marriage. ${ }^{132}$ The word endiablada references the chivalric giant's usual status as pagan or infidel, and fuerza references his physical strength. However, these words also have a metaphorical application to the Christian Fernando. By ignoring the contract of marriage, sworn before the icon of the Virgin Mary, Fernando has violated the terms of his faith. Fuerza, moreover, has a legal meaning as the use of force against someone else's will and is one of the most common Golden Age words for rape. The word indexes the force Fernando employed when he invaded Dorotea's bedroom, physically restrained her, and coerced her into sexual activity. ${ }^{133}$

By presenting her own rape as a story about an evil giant and helpless princess, Dorotea displays her skill in reading her audience. Dorotea's interlocutors will not believe a story about rape in a bourgeois household, but the archetypes of the giant and the princess draw on her audience's habitual reading material and earn immediate recognition. Yet Dorotea's performance as Micomicona also reveals her intellectual limits and her need for collaboration. Dorotea has Micomicona disembark at Osuna, her home city, which lacks a port. Don Quixote, who has apparently had the outward-looking education recommended for men, points this out. Women's education looks inward, to the home, the family, and the spirit, and even

131 Cervantes Saavedra, Don Quijote, I, 30; 373-74; Cervantes Saavedra, Don Quixote, 251.

132 Don Quijote, I, 252; 374; Cervantes Saavedra, Don Quixote, $25^{2}$.

133 Covarrubias's legal definition of fuerça comprises not just rape but any violence that goes against the voluntad ('will') of a victim. It applies to simple assault and abduction as well as sexual assaults. Tesoro de la lengua castellana, $418 \mathrm{r}$. 
Dorotea's mercantile activities do not take her beyond the family farm. She may simply not know the names of Spanish port cities, as she would be unlikely to find them in either devotional books or romances of chivalry, whose geography tends toward the exotic. It is ironic, but indicative of the limits on women's education, that Dorotea can cite the speech of a character from Italian romance and yet does not seem to know whether her own city borders the sea. The priest covers for Dorotea's mistake, showing his own knowledge of the cities of Spain by surmising that Micomicona must have disembarked in Málaga. ${ }^{134}$ The priest's intervention could be taken as officious, or even as an attempt to reassert control over the narrative. However, it could also be taken as collaboration. Fiction requires readers, and plays require spectators. Luscinda lacked such sympathetic interlocutors, but the priest and the other characters present during the Micomicona scene play an essential role as a receptive audience. Indeed, at the inn, the priest proves himself a true ally.

Dorotea's convenient fiction of Micomicona removes the need for her interlocutors to choose between supporting the claims of a peasant woman against a male aristocrat or blaming a victim for crimes perpetrated against her. Both the priest and Don Quixote accept the romance version of Dorotea's plight, and each helps her in his own way. While sleepwalking at the inn, Don Quixote champions Micomicona by beheading the skin of wine he believes to be Pandafilando. The priest provides more concrete assistance by serving as a symbolic church authority to help legalize her clandestine marriage. His is the final speech made to Fernando, the argument that at last persuades the nobleman: 'Si se preciaba de caballero y de cristiano, que no podía hacer otra cosa que cumplille la palabra dada; y que, cumpliéndosela, cumpliría con Dios y satisfaría a las gentes discretas (If he valued himself as a gentleman and a Christian, he could do nothing but keep the promise he had made; by keeping it, he would keep his faith with God and satisfy all discerning people)' ${ }^{\prime}{ }^{35}$ The priest's speech references themes from Dorotea's narrative, namely the spiritually valid clandestine marriage and Fernando's special responsibilities as a caballero. The priest, like Dorotea, represents an unequal marriage as the lesser evil.

In his newfound support for Dorotea, the priest mirrors the hermit Nasciano of Amadís de Gaula, who persuaded Lisuarte to recognize Amadís and Oriana's union. During the civil war, Oriana confesses all to the hermit,

134 Cervantes Saavedra, Don Quijote, I, 30; 375 .

135 Ibid., I, 36; 454; Cervantes Saavedra, Don Quixote, 319. 
and he helps her bargain with the king. ${ }^{136}$ The priest likewise plays marriage broker in Cervantes. Moreover, he appears to have exchanged his initial negative opinion of Dorotea for one that renders her exemplary, telling Fernando that 'pocas o ninguna se le podían igualar (few, if any, women were her equal)'. Laura Gorfkle points out the importance of the priest in persuading Fernando, and for her, this fact signals the defeat of Dorotea's agency. ${ }^{137}$ I disagree with Gorfkle and join Anne J. Cruz in counting the recognition of the marriage as a victory for Dorotea. ${ }^{138}$ Martha García, in a similar vein, reads Dorotea's story as that of the triumph of all women: 'Dorotea shows that women too possess passion, courage, and mental capacity'. ${ }^{139}$ Cervantes defeats social convention by allowing Dorotea to accomplish a feat of literary magic, convincing her fellow chivalric readers to prefer her narrative to others. Even if, as an early modern woman, Dorotea has only incomplete agency, as her society forces her to defer to men in many circumstances, it cannot be denied that through the Micomicona fiction, Dorotea displays both a talent for authorship and the ability to construct her own narrative authority.

Dorotea's success as an author, in turn, leaves the way clear for Luscinda and Cardenio to conduct their own narrative and their own marriage as they see fit. Yvonne Jehenson states of Don Quixote Part I more generally that 'the doubling of characters results in a mirror effect'.. ${ }^{140}$ David Quint agrees that Dorotea and Luscinda face two versions of the same problem, 'male egotism, its relationship to codes of love and honor, and its concomitant victimization of women.' ${ }^{141}$ At the end of the episode, the fates of the two pairs resemble each other and their privileged literary model, the romance of chivalry. The final book of Amadis de Gaula contains the marriage not just of Amadís and Oriana but of all their friends as well, matched into neat, happy pairs. Even if Dorotea's partner is unworthy of her, she has nonetheless succeeded in bringing about the conclusion that she hoped for with the chivalry-inspired clandestine marriage. Cardenio and Luscinda, for their part, have little to lament.

With Luscinda and Dorotea, Cervantes sketches the outline of a community of women readers who might benefit from shared literacy. Luscinda and Dorotea are collaborative readers, though they are not friends or even

\footnotetext{
136 Rodríguez de Montalvo, Amadís de Gaula, II: 1114-15.

137 Gorfkle, 'The Seduction(s) of Fiction', 290.

138 Cruz, 'Dorotea's Revenge', 628.

139 García, La función de los personajes femeninos, 77.

140 Jehenson, 'The Dorotea-Fernando/Luscinda-Cardenio Episode', 210.

141 Quint, Cervantes's Novel of Modern Times, 22.
} 
acquaintances. If Luscinda had not resisted a formal betrothal to Fernando, he would not have been free to recognize his clandestine marriage to Dorotea. If Dorotea had not shared the gossip she heard about the failed betrothal, Cardenio might never have forgiven Luscinda. The resolutions of both episodes have subversive qualities, but together, the implications are even more striking. Cervantes suggests in Part I that communities of women readers are greater than the sum of their parts. The women readers of Part I of Don Quixote are masters of metaphor, of the revelation of truth through art. Together, women have the power to reconcile literature and life that male readers and writers of chivalry seek but rarely find. 


\section{The Defeat of Women Readers of Chivalry in Don Quixote Part II}

Part II of Don Quixote shares Part I's preoccupation with the readership of the romances of chivalry, but its view of the literary market and of women readers is less utopian. While Cervantes in Part II affirms that women can and should read, he presents chivalry as a tool for mischief rather than redemption. This shift reflects Cervantes's increasingly critical outlook on the powers of the reader as Don Quixote Part I circulates on the literary market. In Part II, the character Don Quixote truly has become like Amadís, though not in the way he would have liked. Both Quixote and Amadís are personalities of the printed page, unable to defend themselves against the imitations and interpretations of their readers. As in Part I, chivalric romance remains a tool that can be used to subvert or reinforce social hierarchy. While certain reading women in Part I were able to effect positive change by drawing on chivalric trope, in Part II, women readers of chivalry use their knowledge to corrupt, oppress, and discomfit others.

While characters in Part I observed Don Quixote's chivalric actions and laughed at their discordance with the environment, characters in Part II find in chivalric romance the building blocks for what Vladimir Nabokov terms 'mental cruelties'. ${ }^{1}$ For Don Quixote the character, at least, these cruelties reflect a literary market more hostile to chivalry than ever. Throughout the volume, Don Quixote the character must repeatedly confront his unflattering literary reputation. Indeed, as Howard Mancing has pointed out, Don Quixote Part I enjoyed swift and dramatic success. Printed in an economical octavo format that appealed to silent readers and readers of all classes, the work was published in six editions in 1605 and eleven by $1617 .^{2}$ The characters appeared as personae in public spectacles, and in Mancing's words, 'everyone from the king down to the lowliest peasant knew who the tall, thin knight-errant and his short, fat squire were'. ${ }^{3}$ Adaptations of the work appeared as early as 1605 with Guillén de Castro's Quixote-themed comedia, and Don Quixote proved so successful beyond Iberian borders that

1 Nabokov, Lectures on Don Quixote, 83. For other critics who term the readers in Part II 'cruel,' see Cruz, 'Don Quixote', 372; Quint, Cervantes's Novel of Modern Times, 131; Schmitz, 'Sancho's Courtly Performance', 453 .

2 Mancing, Cervantes' Don Quixote, 152.

3 Ibid. 
it eventually became the work of world literature translated into the largest number of languages. ${ }^{4}$ Don Quixote's reputation precedes him in the second volume, and anyone he meets is likely to be familiar with his mad chivalric exploits. They are more likely to mock him, however, than to celebrate him; even at the zenith of his fame, Don Quixote is an object of ridicule on par with romance personae during their genre's decline.

Amadís, Don Quixote's model for behavior in Part I, becomes an emblem of the negative dimensions of literary fortune in Part II. Don Quixote intuits this link between his hero and himself, and his response upon hearing that some readers consider him a pretentious, poorly dressed madman is to recall similarly impolite readings leveled at the characters of Amadís de Gaula. Quixote reports that certain sinister readers call Amadís's brother Galaor 'más que demasiadamente rijoso' ('more than a little quarrelsome') and Amadís himself a llorón ('tearful'). ${ }^{5}$ The term llorón implies the improper expression of emotion, which is, in this case, coded as feminine, or at the least as an infraction against the standard of masculine behavior. This personal insult to Amadís invalidates the very features of Amadís de Gaula that made it popular in its moment, particularly among women readers. Amadís's extraordinary devotion to Oriana, which led to frequent tears, is his most famous characteristic, and as Chapters One and Two of this book show, chivalric stories that follow the fidelity model popularized by Amadis make room for the agency of women and the representation of women's emotion. Quixote's comment at the outset of the volume looks forward to the gender-normative features of the chivalric imitations in Part II. Indeed, the inspiration for much of the malicious humor in Part II is the notion of chivalric masculinity and its counterpart, chivalric femininity.

The women of Part II, like the women of Part I, shape themselves according to feminine chivalric archetype, but their reading practices are less clever and their imitations more superficial than those of Luscinda or Dorotea. The Duchess and her servant Altisidora, explicit partners in imitation who parallel in some ways the collusion of women readers in Part I, force Don Quixote and Sancho to perform their literary exploits for a household audience, modeling the incorporation of pleasure reading into women's domestic activities. The duchess, though not the most sophisticated appreciator of chivalry in Don Quixote, creates a chivalric reading community for her serving women with herself at the center. For her, the imitation of chivalry is an exercise in control, a tableau of the social hierarchy in which she, 
though obeying the patriarchal authority of her husband, wields power over those below. The duchess's servant Altisidora, whose literacy status is uncertain but whose textual references are more specific than those of her mistress, models an opposing trend: the democratizing influence of print. In this chapter, I trace the relationship among hierarchy, gender, and reading communities, showing how Cervantes uses the Duchess and her household to build a model for his readership and then to critique those readers, especially women readers. Though the Duchess and Altisidora are very different readers, looking at them together allows me to explore reading as a site of class and gender struggle in early modern Spain. Humiliation awaits both women, but only Altisidora redeems herself, suggesting that the emergent print culture allows readers, in particular marginalized readers, to defy authors and authorities.

\section{Reading Communities}

As I discussed in the previous chapter, while readers in Part I often talk about texts together or even collaborate on imitations, no hierarchy orders their reading practices, and their cooperation is tacit rather than explicit. By contrast, the duke and the duchess stand at the head of two articulated reading communities - gendered masculine and feminine - which seek to ossify existing power relations. Roger Chartier observes that gender, along with social class, is a fracture line for early modern reading communities. ${ }^{6}$ That the ducal reading communities are separate reflects a social context in which parameters for intellectual activity vary by gender. Asunción Bernárdez Robal notes that the educational manuals of the day recommended private spaces and religious books to women but encouraged men to occupy public space and read many types of books. ${ }^{7}$ Chartier explains that 'reading is always a practice embodied in acts, spaces, and habits'. 8 The duke, the duchess, and their followers inhabit a space segregated by gender and infected by the imitation of chivalry. Although the duke and duchess likely read the same books, the chivalric performances they sponsor split along gender lines. The duchess and her serving women imitate chivalry in private spaces: the dining room, Don Quixote's sleeping quarters, the duchess's sitting room, and walled gardens. In such episodes as the 
proclamation of Merlin, the petition of the cross-dressed Countess Trifaldi, and the duel between Tosilos and Don Quixote, the duke and his male servants perform chivalry publicly and out-of-doors. ${ }^{9}$ The duke's servants offer Quixote adventures, namely a flight on a magical horse and a joust. The duchess's servants offer him help with personal grooming, gifts of handmade textiles, and love serenades at his window.

As is the case with the romance of chivalry itself, the men's performances are showier and easier to interpret than the women's. The outdoor entertainments at the ducal estate reference the Amadís romances, Espejo de príncipes y caballeros (The Mirror for Princes and Knights, 1555), medieval French Arthurian romance, and, as Giuseppe Mazzotta has discussed, Ludovico Ariosto's Orlando Furioso and Virgil's Aeneid. ${ }^{10}$ While Cervantes credits the duke and duchess with the co-creation of these marvels, it is less clear who read the texts. Mercedes Alcalá-Galán notes that the duchess, at least in public, always submits to her husband's will; perhaps the chivalric theater conforms more to his taste than hers. ${ }^{11}$ In terms of genre coverage, the duke may be a more impressive reader than his wife. He compares Dulcinea to Oriana, Madásima, and Alastraxerea, characters from Garci Rodríguez de Montalvo's and Feliciano de Silva's Amadís romances. The catalog of enchanters the duke's servants evoke includes Arcaláus and Alquife, of Amadís romances by Montalvo and Silva, respectively, and Lirgandeo, the enchanter of Espejo de príncipes. ${ }^{12}$ Urganda la Desconocida of Amadis de Gaula is notably absent. Dulcinea, the largest chivalric role given to a female character in the tableau, is played by one of the Duke's pages. Even those roles played by men that do not come from existing chivalric texts tend to be specific. The countess Trifaldi and her squire Trifaldín have names and an origin story, and the wealthy farmer's son whom Tosilos plays in the joust is a specific person rather than an archetype. The duke's male underlings may not be readers themselves, but they do appear to understand their roles and are thus part of a well-functioning reading community.

While the men and their collective reading practices could be seen as dominant in the ducal household, this chapter emphasizes the more subtle chivalric theater the duchess and her ladies enact within the domestic

9 One particular page, assigned to play Dulcinea, breaks with this paradigm to some degree. He is initially depicted as being an underling to the duke's mayordomo or steward, who plays the roles of Merlin and Countess Trifaldi, but he also reports directly to the duchess, serving as her messenger to Teresa Panza. See Cervantes Saavedra, Don Quijote, II, 36; 320, II, 50; 418.

10 Mazzotta, Cosmopoesis, 85-88.

11 Alcalá Galán, 'Las piernas de la duquesa', 29.

12

Rey Bueno, Quijote mágico, 50. 
sphere. Though the duchess's actions are sometimes difficult to distinguish from those of her husband, critics agree that she is conversant with chivalric trope. The duchess submits to her husband when he is present, but she also undertakes chivalric activity on her own. For José María Paz Gago, the evidence suggests that she is a 'compulsive reader' of chivalry. ${ }^{13}$ Martha García refers to her as the director of the chivalric tableaux at the ducal estate, and Judith Whitenack and Julia Barella argue that she co-organizes the collaborative imitations. ${ }^{14}$ Yet the duchess provides no direct evidence of chivalric reading outside of Don Quixote Part I, perhaps reflecting the fact that by the early seventeenth century, many readers of Don Quixote were familiar with the names of Amadís and other knights or perhaps had experienced the characters as part of public spectacle but had not read the books. ${ }^{15}$ The duke and duchess do not speak of owning books of chivalry, and they certainly do not come into physical contact with a copy of Amadís as Cardenio and Luscinda did in Part I.

The duchess and her women imitate chivalric behaviors and tropes rather than specific characters or lines of text. The duchess's female servants may or may not have direct experience of chivalry through silent or out-loud reading, but they have evidently received instruction in chivalric culture, likely from the duchess herself. Of the duchess's female servants, Altisidora comes across as the most sophisticated in terms of her intertextual references, and she is arguably more conversant with chivalry than her mistress. Altisidora pretends to be in love with Don Quixote, enacting a chivalric motif, but her reference points come not from Iberian romance, but from Don Quixote Part I, Orlando Furioso, Petrarchan lyric, Garcilaso de la Vega, Virgil's Aeneid, and Dante's Inferno. Altisidora is an expert performer of literary trope, and her favorite texts have greater prestige at the turn of the seventeenth century than the romance of chivalry. The duchess assigns herself a chivalric role, that of the enchantress, but her references to the genre are less specific than those of Luscinda, Dorotea, and even Maritornes and the innkeeper's daughter in Part I. The duchess's innovation as a reader comes not from her expertise with Iberian romance but from her desire to make the imitation of chivalry a community affair for women.

Literate men in early modern Spain had access to institutions like schools, universities, the Church, the print industry, royal bureaucracy, and the court 
through which to make their reading practices collective and formal. The women mentioned in earlier chapters, real and fictional, were educated in relative isolation, accessing literary culture piecemeal and expressing their literacy through private devices like letters. In a sense, the duchess liberates her female servants through providing them a collective education. Although the duchess commissions chivalric performances from her ladies that conform to the existing household hierarchy, the servants ultimately use chivalry to escape her control. Through the duchess and her ladies, Cervantes models the transformative potential of the early modern literary market for the woman reader. Women readers-even those who are members of the lower classes - find in their access to print culture a means to disrupt the social order, including traditional notions of gender roles.

\section{Social Class, Gender, and Chivalric Reading}

As a wealthy noblewoman, Cervantes's duchess is an appropriate leader for a reading community of women. Paz Gago has argued that the duchess represents the aristocrats of Golden Age Spain who frequently retired to country estates in pursuit of three pastimes: 'appearance [...] reading, and hunting. ${ }^{16}$ Chivalry is likewise a suitable genre choice. Daniel Eisenberg points out that folio-sized printed romances were more expensive than works in other genres and thus marketed toward those who could afford luxury. ${ }^{17}$ For bourgeois readers of chivalry, the discourse of individual merit that Jesús Rodríguez Velasco terms the 'chivalric fable', which undermines questions of lineage in many chivalric romances, likely held some appeal. ${ }^{18}$ Critics generally agree, however, that the nobility comprised the genre's implied reader. Maxime Chevalier writes that the romances of chivalry served as a 'literature of evasion' for aristocrats, allowing an imaginative escape from the city, the court, and an increasingly mercantile economy. ${ }^{19}$ Augustin Redondo concedes that bourgeois or even illiterate consumers of romance probably existed, but he agrees with Chevalier and Eisenberg that the primary audience for chivalry would have been aristocratic. ${ }^{20}$ The duchess appears to absorb the genre's insistence on rank, and she expects her 
servants' chivalric imitations to adhere to decorum. The duchess's chivalric fantasy never brings into question the social categories of the 'real' world, and one of the reasons Sancho and Quixote become targets for ridicule is that they have made gestures toward social mobility. The hidalgo's pretension to the title don and Sancho's gubernatorial ambitions indicate that they, unlike the duchess, appreciate the promises of class mobility contained in the chivalric fable. One wonders how the duchess might have absorbed the ideological ambivalence of Don Quixote Part I; perhaps she, like many other early readers of Don Quixote, read the novel superficially, as a work of broad humor but little depth. ${ }^{21}$

Given early modern Iberian restrictions on women's autonomy, the duchess might seem an unlikely figure of the reader, but though the duchess's gender limits her in some ways, it does not disqualify her from this role. A significant number of Golden Age women read romances of chivalry, and many women who could not read also had some access to these texts. Barbara Weissberger remarks that the aristocratic women to whom many romances were dedicated were a significant portion of chivalry's readership and had considerable influence in the public sphere. ${ }^{22}$ Lisa Vollendorf argues that notions of the early modern literary public should include less privileged readers, among them 'phonetic readers, comprehensive readers, and merely "aural consumers" of early modern texts', many of whom would have been women. ${ }^{23}$ As discussed in the previous chapter, Don Quixote Part I contains several characters who are likely illiterate but who appreciate chivalry nonetheless, including Maritornes and the innkeeper's daughter.

The two lower-class female consumers of romance from Part I are useful for thinking about the women readers of Part II because they imitate chivalry together. In a parody of the nocturnal meetings between lovers in chivalric romance, they play a joke on Don Quixote that ends with his hand tied to the stable wall. Neither civic nor parental authorities appear to notice that two peasant women have committed an offense against a social superior. Don Quixote himself attributes the event to encantamento ('enchantment'), as he did in his first nocturnal encounter with Maritornes, in which he imagined that she was an enamored damsel and inadvertently caused her to be beaten. ${ }^{24}$ The seizure of Don Quixote's hand perhaps even serves as a kind of poetic justice, a petty entrapment in payment for petty assault. 
Maritornes and the innkeeper's daughter use their knowledge of chivalry to act above their social station, and in Part I, they get away with it.

Juan Palomeque's inn is comparable to the ducal estate in some ways and distinct in others. The inn offers a space where members of different social classes listen to and discuss literature and in which social upheaval and reconstruction inspired by chivalry are possible. The duke and duchess have created a similarly corporate experience of reading for their servants. Retribution and revenge feature in chivalric imitations at the ducal estate, as they do with Maritornes and the innkeeper's daughter, but in Part II, the physical stakes are higher, and violations of the social order are followed by punishment. Sancho must self-administer real lashes in payment for an imaginary offense, and Don Quixote suffers physical damage to his face for a verbal affront to Altisidora. The servant girl, for her part, is condemned to a (metaphoric) hell for the presumption of playing a chivalric joke on Don Quixote. While the inn of Part I is a place where social class can be evaluated and remade, as in Dorotea's reconciliation with Fernando and the captive's unlooked-for restoration to family and wealth, the ducal household proves a slippery locus of change. However, both chivalric gathering places have in common the bifurcated nature of the roles they assign. With some exceptions, as with the cross-dressed Dulcinea at the ducal estate, the chivalric tableaux adhere to the gendered division of behavior present in Iberian romance.

\section{The Duchess as a Literate Enchantress}

Female characters in the romance of chivalry typically congregate in a royal household not dissimilar to the duchess's domestic circle. They are queens, princesses, ladies-in-waiting, and lower-class servants who spend their days reading, singing, playing music, sewing, and participating in courtly ceremony. Eisenberg states that female chivalric characters 'did not travel for pleasure or amusement; in fact, except for women in search of assistance or carrying out some vow, they did not travel at all unless forced to by evil-doers'. ${ }^{25}$ The duchess, however, assigns herself one of the few chivalric roles that gives women a high degree of agency and freedom, that of the sabia or enchantress. ${ }^{26}$ Many enchantresses in the Iberian tradition take the

26 Vladimir Nabokov refers to the duke and duchess as an enchanter and enchantress 'invented by the master enchanter, Cervantes'. See Lectures on Don Quixote, 63 . 
Lady of the Lake of the prose Lancelot as their model. These magical women are explicitly literate, and both they and the texts they create circulate through the romance world. Like other enchantresses featured in this book, including Montalvo's Urganda la Desconocida and Beatriz Bernal's Membrina, the duchess performs her magic via the interpretive pressure she asserts over the lives of others, in this case Don Quixote and Sancho. In her dress and actions, the duchess deliberately plays to the enchantress type, layering imitations of several powerful enchantresses in the romance tradition. Yet despite her beautiful exterior, the duchess also embodies the negative qualities of the enchantress, expressed in the ugliness that festers just below the surface and which reveals itself without the duchess's volition.

Don Quixote's initial encounter with the duchess in the forest suggests her as a figure of the evil enchantress, familiar from both Iberian and Italian chivalric texts. While good enchantresses like Urganda and Membrina protect and guide Christian knights, enchantresses of ill intent attempt to harm, seduce, or imprison them. ${ }^{27}$ Judith Whitenack observes that Don Quixote, unlike many male protagonists of Iberian romances of chivalry, never succumbs to erotic enchantment. ${ }^{28}$ Though Maritornes, the duchess, Altisidora, and even Dorotea attempt to entrap him with quasi-erotic promises, they never shake his fidelity to Dulcinea. The duchess leaves the seduction of Don Quixote to her handmaiden, but she does attempt to distract Don Quixote from his mission, and indeed, she succeeds in delaying him at the ducal estate through strategies both flattering and cruel. In this, the duchess resembles enchantresses of the Italian tradition, including Ariosto's Alcina and Tasso's Armida, who use a combination of magic and persuasion to trap knights. Ariosto's Alcina entices Ruggiero to stay on her magical island, delaying his destiny and preserving his life. He is fated to die soon after he converts to Christianity, marries Bradamante, and founds the Este dynasty. ${ }^{29}$ Tasso's Armida, who shelters Rinaldo in her magical garden and keeps him from the fighting at Jerusalem, employs strategic delay in a similar way. $3^{0}$

In evoking Alcina and Armida, whose beauty, like that of Cervantes's duchess, belies their moral corruption, Cervantes reworks not only Italian epic but also Part I. As the previous chapter discussed, Dorotea, like the duchess, is a declared reader of chivalry and a figure of Armida. In Part 
II, however, Cervantes opts for a more sinister interpretation of the figure from Tasso. No virtuous motives can be ascribed to the duchess, and her home is a theatre of humiliation, not a pleasure garden. It is worth noting, moreover, that Dorotea's performance of the enchantress is more specific than that of the duchess, as she cites Armida's language, rather than just her general characteristics. The duchess adapts from the maga archetype her literacy, her power, and her ambivalent morality without any of the softening features of particular enchantresses.

The duchess has few sympathetic qualities, and her intentions for her prey are sinister. Don Quixote, for his part, has also changed. He was helpless before Dorotea/Micomicona's elegant request, but he enters the duchess's sphere of influence prepared to cope with enchantment, good or evil. Travel by purportedly magical boat precedes the encounter with the duchess. On encountering a boat in the wilderness, Don Quixote explains to Sancho that chivalric enchanters use their magic to help knights travel long distances: 'O le arrebatan en una nube o le deparan un barco donde se entre, y en menos de un abrir y cerrar los ojos le llevan, o por los aires, o por la mar, donde quieren y donde es menester su ayuda (Either they carry him off on a cloud or provide him with a boat which he enters, and in the blink of an eye they move him through the air or over the sea, wherever they wish and wherever their help is needed)' ${ }^{31}$ Though many romances of chivalry involve magical transportation, the coincidence of the ship, the cloud-vehicle, and a nearinstantaneous voyage to foreign lands points to one particular romance as a potential intertext for this passage. El conde Partinuplés (Count Partinuplés), a fifteenth-century translation of the anonymous twelfth-century French Partonopeus de Blois, features an enchantress named Melior who makes scouting trips on a cloud and then sends a ship that steers itself to bring a French prince to her enchanted castle. ${ }^{32}$ This romance, incidentally, is also a probable source for Beatriz Bernal, as discussed in Chapter Two. The magic ship to which Don Quixote alludes transports Partinuplés to an estate with invisible servants who rearrange household objects and a seductive lady (Melior) who will only meet him in the dark. The plot of the romance is a gender-switched version of the story of Cupid and Psyche from Apuleius's The Golden Ass. The Iberian El conde Partinuplés, the source material for the seventeenth-century Ana Caro play of the same name, was reprinted several times in the sixteenth century and was widely known; Apuleius was likewise familiar to Cervantes's contemporaries in Spanish 
translation..$^{33}$ If indeed Cervantes references Partinuplés in this passage, it seems fitting considering the themes of entrapment and deception that will be important in the subsequent episodes. The duchess appears at the right place and time to play the role of the highly educated but morally ambivalent enchantress. The Melior of the romance is, by age three, 'la más sabia de todas las mugeres del mundo (the wisest woman in the world)'. ${ }^{34}$ The duchess is the most educated woman in her world, and she has the power to confine Don Quixote physically and impose her interpretations of literary texts on him and on others.

The duchess presents herself as bait for a trap, like both Tasso's Armida and Melior of Partinuplés. Don Quixote and Sancho happen upon her in a secluded forest, seated upon her palfrey, with a bird of prey on her arm. ${ }^{35}$ The encounter carries with it connotations of mystery, aristocracy, and magic. The duchess greets Sancho as if he were a long-expected emissary: 'Levantaos del suelo; que escudero de tan gran caballero como es el de la Triste Figura, de quien ya tenemos acá mucha noticia, no es justo que esté de hinojos (Rise up from the ground; it is not right for the squire of so great a knight as the Knight of the Sorrowful Face, about whom we have heard so much, to remain on his knees) ${ }^{36}{ }^{6}$ The duchess at once reveals her familiarity with Don Quixote Part I and her desire to exert control over that text. Sancho has introduced Don Quixote as the Caballero de los leones ('Knight of the Lions'), alluding to a recent triumph, while the duchess reasserts an older title from Part I.

The duchess's clothing, moreover, reinforces her moral ambivalence and her link to magic. She wears a green hunting outfit, a vaquero, which has evident predatory overtones. Carmen Bernis Madrazo describes the skirted vaquero as less heavy and restrictive than aristocratic formal attire and notes that warrior women on the Golden Age stage are often depicted wearing it. ${ }^{37}$ The vaquero, moreover, corresponds with the physical movement granted to enchantresses in Iberian chivalry. The duchess's costume is green, according to Bernis Madrazo a usual color for hunting dress. ${ }^{38}$ Julia Barella and Anne J. Cruz note the association of the color with madness, and Barella also

De Armas, Invisible Mistress, 171-74; Luna, 'Introducción', 41.

Monzó, 'Partinuplés', 412.

35 David Quint observes that the female characters in romances of chivalry always ride palfreys.

See Cervantes's Novel of Modern Times, 131.

36 Cervantes Saavedra, Don Quijote, II, 30; 269; Cervantes Saavedra, Don Quixote, 654.

37 Bernis Madrazo, 'El traje de la duquesa cazadora', 62.

38 Ibid., 66. 
links it with the concept of hope. ${ }^{39}$ Martha García observes that medieval literature associated the color green with the precious emerald and used it as a symbol for femininity. ${ }^{40}$ These divergent interpretations demonstrate that green is multivalent and not always associated with positive qualities.

In Iberian romance, the color green also has a history of association with another ambivalent force-magic. Feliciano de Silva's Florisel de Niquea Part IV features an enchantress wearing green who traps knights and ladies in a magical castle. The maga Sinestasia creates a ludic space of danger and delight for Florisel's entire cast. She raises a magical mist at the border of the woods surrounding her castle, trapping everyone within. The ladies roam the castle freely, but they can only travel in the forest while protected by a bubble of enchantment. The knights remain in the woods, exposed to danger from beasts and from each other. In Sinestasia's magical wilderness, men and women can speak and interact, but they cannot touch. Sinestasia wears a green dress each time she goes out into the woods, perhaps signifying magic itself or the vain hopes of her affection for Rogel de Grecia. ${ }^{41}$ Feliciano de Silva's romances have been a frequent reference point for Cervantes, and he mentions two of the characters of Florisel de Niquea Part IV, Daraida and Garaya, male warriors cross-dressed as women, in Don Quixote Part I. ${ }^{42}$ Silva's Sinestasia is a sympathetic character, but her love for Rogel de Grecia goes unrequited, and her enchanted castle, like the duchess's estate, ultimately fails to hold her prey.

Like other enchantresses of ambiguous moral status, the duchess conceals a festering ugliness under a veneer of beauty. During the initial meeting with Quixote and Sancho, the text describes the duchess as gallarda ('elegant') and bella ('beautiful'). ${ }^{43}$ Quixote remarks on her gran fermosura ('great beauty'), and Sancho is described as 'admirado [...] de la hermosura de la buena señora (amazed by the beauty of the good lady)'. ${ }^{44}$ Fermosura is a linguistic archaism, and Howard Mancing has shown that such constructions accompany Quixote's imitations of chivalry. ${ }^{45}$ The duchess is a corrupt reader of chivalry, and her gallant appearance is deceptive. The servant

39 Cruz, 'Don Quixote', 374; Barella, 'Atardece en la casa de placer', 263. As Chapter Two discusses, in Beatriz Bernal's Cristalián de España, the symbolic damsel who wears a green dress and carries a green apple likewise symbolizes hope.

40 García, La función de los personajes femeninos, 105.

41 Silva, Florisel IV, 22r-28v.

42 Cervantes Saavedra, Don Quijote, I, 24; 297.

43 Ibid., II, 30; 268-69.

44 Ibid., II, 30; 270; Cervantes Saavedra, Don Quixote, 653.

45 Mancing, The Chivalric World of Don Quijote, 32. 
Doña Rodríguez, likely with malicious intent, reveals her lady's secret ill health, which indexes her moral corruption.

The serving woman attributes the duchess's beauty to the salutary effects of 'dos fuentes que tiene en las dos piernas, por donde se desagua todo el mal humor (two issues she has on her legs, which drain the bad humors that the doctors say fill her body)'. ${ }^{6}$ Mercedes Alcalá Galán describes these fuentes as the consequence of medical bloodletting. ${ }^{47}$ Their purpose, Alcalá argues, would not have been cosmetic, though cosmetic secondary effects have been attributed to the procedure. ${ }^{48}$ Though many scholars have read the duchess as a middle-aged or elderly woman, for Alcalá, her beauty and vigor indicate that she is of childbearing age. No children are mentioned in connection with the ducal couple, and Alcalá surmises that the fuentes are a treatment for infertility. ${ }^{49}$ These open wounds would have severely impacted the duchess's health and perhaps even created a foul smell; Alcalá notes that the ill humors that exited them would have been the consequence of infection..$^{0}$

The contrast between beautiful appearance and corrupt reality renders the duchess an object of disgust. Chivalric enchantresses likewise have a dual physicality, one part attractive and one part loathsome. Urganda la Desconocida first appears to be a young lady of eighteen, but when she wipes magical ointment from her face, she reveals herself to be an old woman..$^{1}$ Ariosto's apparently beautiful Alcina is revealed to be 'exceptionally ugly' when Ruggiero puts on a magic ring that protects its wearer from the effects of enchantment. $5^{2}$ In the case of Alcina, physical ugliness indexes moral impurity. The duchess's fuentes likewise reveal multiple sources of secret shame: her childlessness, her repulsive physicality, and her lack of control over her own household.

\section{Rewriting Don Quixote Part I}

If the duchess is an enchantress, she is one who does not possess absolute power. Rather, she enters into conflict with Quixote, Sancho, and the

Cervantes Saavedra, Don Quijote, II, 48; 403; Cervantes Saavedra, Don Quixote, 771.

Alcalá Galán, 'Las piernas de la duquesa', 15.

48 Ibid., 20.

49 Ibid., 15-17.

50 Ibid., 21.

51 Rodríguez de Montalvo, Amadís de Gaula, I: 256.

52 Larrington, King Arthur's Enchantresses, 145. 
members of the household as they struggle to promote their own interpretations of chivalric romance. Dulcinea is a frequent subject of inquiry, which implies competition between the duchess and Quixote's ideal woman. The duke explicitly compares the two, favoring Dulcinea. Don Quixote praises the duchess as the 'digna señora de la hermosura (most worthy mistress of beauty)', and the duke replies: 'Adonde está mi señora doña Dulcinea del Toboso, no es razón que se alaben otras fermosuras (When Señora Doña Dulcinea of Toboso is present, no other beauty should be praised)'.53 The duchess later alleges that Dulcinea is entirely imaginary: 'Vuesa merced la engendró y parió en su entendimiento (Your grace engendered and gave birth to her in your mind)' ${ }^{54}$ In Part I, Dulcinea is a hybrid of the fantastic and the verisimilar. In the 1605 volume, Don Quixote is clear in his idea that the name Dulcinea represents Aldonza Lorenzo, a village girl he admires, just as the name Rocinante represents his pre-existing horse. In Part II, Sancho refers to Dulcinea as Aldonza Lorenzo in his letter to his wife, but Don Quixote never references the lady by her peasant name. Perhaps the duchess's influence cements an already developing change in Quixote's notion of the character, which distances Dulcinea from her once-humble social status. The duchess contests the authority of Part I of Don Quixote, attempting to substitute herself as a competing author-figure, and as regards Dulcinea, she achieves a measure of success.

In subsequent conversations with Don Quixote and Sancho, the duchess returns to a particular detail, the image of Dulcinea winnowing buckwheat, 'cosa que me hace dudar en la alteza de su linaje (which makes me doubt the nobility of her lineage)'. ${ }^{5}$ Quixote and Sancho offer different explanations. Don Quixote blames enchanters for the indecorous appearance of Dulcinea, and Sancho blames himself. However, the duchess has her own reading of the event: Dulcinea is real, Dulcinea is noble, and Dulcinea, Sancho, and Quixote have all been enchanted. The duchess declares that she will make her reading canonical: 'Yo desde aquí adelante creeré y haré creer a todos los de mi casa, y aun al duque mi señor, si fuere menester, que hay Dulcinea en el Toboso, y que vive hoy día, y es hermosa, y principalmente nacida (From now on I shall believe, and make my entire household believe, and even my lord duke, if necessary, that Dulcinea exists in Toboso, and that she lives in our day, and is beautiful, and nobly born) ${ }^{\prime}{ }^{6}$ The duchess's 
comment represents one of the few moments where she pushes back against her husband's authority. Here, the duchess is ready to overrule three men: her husband, Don Quixote, and Sancho. Don Quixote largely defers to her. The knight cares about Dulcinea's beauty, but he appears content with metaphorical existence and metaphorical lineage. About the reality of Dulcinea, he comments: 'Dios sabe si hay Dulcinea o no en el mundo (God knows if Dulcinea exists in the world or not)'. ${ }^{57}$ On the issue of lineage, he replies that 'Dulcinea es hija de sus obras, y [...] las virtudes adoban la sangre (Dulcinea is the child of her actions, and [...] virtues strengthen the blood).$^{5}{ }^{8}$ Roberto González Echevarría points out that Part I represents Don Quixote's ideal mistress as a labradora ('working-class woman') with a name, parents, a personality, a physical appearance, a geographical origin, and a history of acquaintance with Don Quixote. ${ }^{59}$ The 'real' Dulcinea of Part I-Aldonza Lorenzo - could not be more different from the duchess. She is a vigorous, hard-working, illiterate peasant of attractive but somewhat masculine appearance. ${ }^{60}$ The duchess's vision of Dulcinea shows that what she values in the romance of chivalry is nobility and archetypical femininity. Aldonza Lorenzo does not fit the duchess's concept of chivalric romance, and all trace of her must be expunged.

The conversation between Sancho and the duchess represents another attempt to impose her reading of Part I on others. Elias Rivers remarks that it is inappropriate for the duchess to invite a man from the working class into the privacy of her domestic apartment to converse with her and her ladies. ${ }^{61}$ However, if one thinks of Sancho as a synecdoche of the book in which he is a character, it makes sense that he would be allowed to invade the domestic space. Aristocratic women entertain themselves with books, and the duchess and her ladies entertain themselves by speaking to Sancho. The duchess forces Sancho to retell the enchantment of Dulcinea in a scene that mimics out-loud reading before a group. When Sancho has finished, the duchess seeks to change his interpretation of events: 'Toda fue invención de alguno de los encantadores que al señor don Quixote persiguen; porque real y verdaderamente yo sé de buena parte que la villana que dio el brinco sobre la pollina era y es Dulcinea del Toboso, y que el buen

Ibid., II, 32; 290; Cervantes Saavedra, Don Quixote, 672.

59 Roberto González Echevarría offers a reconstruction of the 'real' relationship of Don Quixote and Aldonza Lorenzo, emphasizing the social and legal implications of Quixote's fascination with the peasant girl. See Love and the Law in Cervantes, 38-41.

60 Cervantes Saavedra, Don Quijote, I, 25; 311-13.

61 Rivers, 'Sancho y la duquesa', 38. 
Sancho, pensando ser el engañador, es el engañado (It was all an invention of one of the enchanters who pursue Señor Don Quixote, because really and truly, I know from a reliable source that the peasant girl who leaped onto the donkey was and is Dulcinea of Toboso, and that our good Sancho, thinking he was the deceiver, is the deceived)'. ${ }^{62}$ The duchess herself is the reliable source and the enchantress of this episode; she rewrites Dulcinea for her own amusement.

The duchess is not content with changing Sancho's understanding of events. She is determined to influence his wife, Teresa Panza, as well. When Sancho writes a letter to Teresa, informing her that the duke plans to give him the governorship of an insula, the duchess arranges for delivery and pairs the missive with one of her own. Letter writing was among the ordinary preoccupations of noblewomen at the turn of the seventeenth century. Montserrat Pérez-Toribio argues that, for historical women, letter writing lent itself perfectly as an instructional medium through which women created an effective support system, a sanctioned means of expression that surreptitiously allowed them to communicate about matters other than classic maternal or filial responsibilities'. ${ }^{63}$ Letter writing is also a chivalric enterprise, and the duchess is not the first female character in Don Quixote to write a letter in imitation of chivalry. The previous chapter treats at length the moment when, in Part I, Luscinda tucks a letter for Cardenio in a copy of Amadis de Gaula, implying that it must be read against that text in order for its full meaning to emerge.

The duchess's letter, however, is quite different from Luscinda's private, emotional plea. The duchess evokes chivalry to mock Teresa for her low status. The letter resembles chivalric letters of prophecy, with an important difference - none of the duchess's predictions come true. The duchess writes of a future of prosperity and social advancement for Sancho's family that she knows will never arrive. She pairs the letter with a gift, a coral necklace. In sending this letter, the duchess channels Urganda's prophetic letters from Amadis de Gaula, discussed in Chapter One, which were sent with jewels. Urganda's letters predict the fates of important characters and help end a civil war. When her predictions come true, the king has them read aloud to the court, increasing the enchantress's prestige.

The duchess's letter to Teresa Panza is a prediction meant to be read aloud but never meant to come true. The duchess addresses Teresa in familiar terms, as Amiga Teresa ('my friend Teresa'), and promises future 
acquaintance: 'Tiempo vendrá en que nos conozcamos y nos comuniquemos (One day we shall meet and communicate with each other), ${ }^{64}$ If this time ever arrives, it will be when Cervantes's Part II of Don Quixote is published and Teresa Panza joins the other characters in the library of the ducal household. The duchess asks for a gift from Teresa, bellotas ('acorns'), that hints at the literary nature of her acquaintance with the Panza family. The request references Don Quixote and Sancho's humble meal in Part I with the goatherds; a handful of acorns evoked for Don Quixote the golden age of humankind, in which people enjoyed nature's bounty freely and without violence. ${ }^{65}$ Acorns have an implication for social class; in the meal with the goatherds, they were gifts offered from the humble to the great and shared together. Though it seems a utopian moment, the goatherds have less food for themselves because they shared with an hidalgo; Quixote can offer them only a fine speech in return. ${ }^{66}$ The duchess extends to Teresa Panza an equally dubious courtesy.

Teresa Panza's response to the letter is as exuberant and presumptuous as the duchess could have hoped. Teresa interprets the letter literally rather than through its chivalric frame. She finds acorns to send the duchess and plans an appearance at court. The letter appears to have accomplished the duchess's true purpose, exposing Teresa Panza to public ridicule. Because Teresa is illiterate, she needs a proxy in order to read the letter. Unlike Sancho's imaginary Dulcinea in Part I, she does not mind if others learn her business as they lend her their reading skills. The entire community, including Sansón Carrasco and the priest, finds out about Sancho's governorship, and the reply letter, also written by proxy, reflects their puzzlement. Teresa's ambitions delight the women of the ducal household, as they can laugh at her grasping for position and poor taste. Yet when Teresa Panza learns that Sancho's governorship has been a failure, both she and her daughter, Sanchica, accept the news with equanimity. They focus on the positives of the situation; their beloved Sancho has returned to them with more money than he had when he left. ${ }^{67}$ Their reaction demonstrates that the duchess's influence is not absolute. She cannot draw Teresa Panza into an aristocratic fantasy for long, as she has misunderstood the labradora's resilience and pragmatism. The null effect of the duchess's letter in Part II reveals the limitations of the interpretative power of readers, especially of

64 Cervantes Saavedra, Don Quijote, II, 50; 418; Cervantes Saavedra, Don Quixote, 785 .

65 Cervantes Saavedra, Don Quijote, I, 11; 155.

66 Cascardi, Cervantes, Literature, and the Discourse of Politics, 66.

67 Cervantes Saavedra, Don Quijote, II, 73; 583. 
aristocratic readers. The duchess likewise has a limited power to control the other readers in her reading community, especially her protégée Altisidora.

\section{Altisidora's Literary Rebellion}

Altisidora, the duchess's favorite handmaiden, joins with her fellow servants in a collective response to the romance of chivalry. Martha García emphasizes the theatrical dimensions of these scenes; for her, the servants are actresses the duchess has tasked with enacting a series of mock-chivalric rituals. ${ }^{68}$ Though the duchess attempts to impose her own reading strategies on her female servants, Altisidora escapes her. Altisidora is an interesting test case for the duchess's reading community. We have no direct evidence of her literacy, but her poems reveal extensive knowledge of literary culture. As a young servant of uncertain economic status, Altisidora might be expected to have little interest in or access to literature. Yet she is among the most creative literary performers on the ducal estate, able to combine genre references and parody literary tropes. Instead of imitating Don Quixote's reading habits, as the duke and duchess apparently do, Altisidora draws on an international set of texts important to Cervantes over the course of the novel. Her ludic iterations of literary trope show that the consumption of literary texts is a diffuse practice that extends across class lines and perhaps even beyond literacy to serve as a catalyst for social transformation.

Don Quixote's reprimand to Altisidora at first seems puzzling, as he criticizes her for using chivalry much in the way he does, as inspiration for new behaviors. In critiquing Altisidora's performances, Don Quixote draws on the language of the conduct tradition, which opposed the romance of chivalry and all other entertainment-oriented reading, especially for women. When Altisidora attacks Don Quixote by means of chivalric trope, she also attacks the social discourses, including conduct literature, which seek to limit women's behavior. In the episodes that concern the duchess's female servants, Cervantes emphasizes domestic enclosure of the kind conduct writers universally advocated. The objects featured in the indoor tableaux, which include towels, basins, soap, musical instruments, garments, pins, and slippers, index women's daily occupations and pastimes. Even the cats that scratch Don Quixote are domestic and not wild beasts. It must be said, however, that though Quixote critiques Altisidora's apparent love for him in terms that support the entrapment of women, it does not follow that 
Cervantes's opinion of female rebellion by way of literature is the same as the knight's.

Initially, the damsels of the ducal household imitate chivalry at their mistress's command. When Don Quixote arrives, the ladies disarm him without laughing, according to precise orders: 'Seis doncellas le desarmaron y sirvieron de pajes, todas industriadas y advertidas del duque y de la duquesa de lo que habían de hacer (Six maidens removed his armor and served as pages, all of them instructed and advised by the duke and duchess as to what they were to do). ${ }^{69}$ Such scenes are frequent in Iberian romance, and they signal hospitality and friendship. A knight who refuses to remove his armor, concealing his identity and remaining ready for battle, expresses distrust toward his hosts. Though the description credits both the duke and duchess with giving the orders, these are the duchess's handmaidens, and they are likely to be more solidly under her control than under her husband's, as they belong to her sphere of influence. A short while later, these same women invent their own chivalric welcome ritual, one perhaps meant to indicate to Don Quixote that he has accepted the hospitality of enemies, not friends. They arrive in the dining room with basins of water, towels, and soap, and instead of helping the diners wash their hands, they wash Don Quixote's beard. The duke and duchess 'de nada desto eran sabidores (knew nothing about this)', and to maintain the appearance of authority, the duke demands that his beard be washed as well. $7^{\circ}$ Every time the duke and duchess involve their servants in their imitative reading practices, the situation risks escaping their control.

Altisidora pursues Don Quixote with the duchess's consent, and the details of her performance reference both chivalry and early modern representations of women's daily lives. I consider Altisidora an inscribed reader of chivalry, though whether she has read chivalry on the page or heard chivalry aloud is unclear. She makes no specific references to Amadís de Gaula or Feliciano de Silva's romances, but she does understand the genre well enough to communicate with Don Quixote through a shared notion of chivalric trope. When Quixote hears her first song, he muses on chivalry: 'Le vinieron a la memoria las infinitas aventuras semejantes a aquélla, de ventanas, rejas y jardines, músicas, requiebros y desvanecimientos que en los sus desvanecidos libros de caballerías había leído (He remembered an infinite number of adventures similar to this one, with windows, jalousies, gardens, music, amorous compliments, and swoons, which he had read in his delusive 
books of chivalry)'. $\cdot^{1}$ There are many lovesick knights and ladies and many nocturnal meetings in the chivalric tradition. The rendezvous between Oriana and Amadís at her window in Amadís de Gaula is a midpoint, not the origin, of the trope: it reflects the influence of the prose Lancelot and generates echoes in many texts, including Don Quixote Part I. ${ }^{72}$ Cervantes's Part I, meanwhile, provides additional models for Altisidora's interpretation of the motif. Both Fernando and Luis haunt ladies' windows by night, attempting to seduce women through song. ${ }^{33}$

Altisidora's first song layers references to literary culture, and both her physical position as the musician and the lyrics imply gender reversal. Altisidora uses stock images from lyric poetry to describe Don Quixote. His eyes are dos soles ('two suns'), and she credits him with youth, beauty, and valor. ${ }^{74}$ Altisidora then references Part I by expressing a wish to trade places with Dulcinea. She goes on to reveal some degree of historical education by referring to Don Quixote as the emperor Nero, gazing down on a burning Rome. The song ends with two images of subtler provenance. Altisidora accompanies the blazon of Don Quixote with a series of garments that she will make for him:

Oh, qué de cofias te diera

qué de escarpines de plata

qué de calzas de damasco

qué de herreruelos de holanda

(O, what fine caps I would give you,

and oh, what gaiters of silver,

and oh, what breeches of damask,

And oh, what short capes of linen $)^{75}$

Altisidora promises Quixote four items of fine clothing: a cap, slippers, breeches, and a cape. There is something intrusive in the offer, as articles of clothing enter into intimate contact with the body. Nancy Vickers argues that the conventions of Petrarchan lyric deny subjectivity to women by reducing them to eyes, lips, cheeks, hands, and other stereotypically beautiful features. Altisidora's list of garments performs the same 'scattering' that Petrarchan 
lyric enacts on women by dividing Quixote's body into parts..$^{6}$ Clothing can also substitute for bodies in Petrarchan lyric, as in Garcilaso's 'Oh dulces prendas, por mi mal halladas (Oh sweet tokens, found to my despair)', in which an article of clothing reminds the poetic speaker of his lost beloved.

Altisidora follows the blazon of Don Quixote with a more conventional one enumerating her own traits. Aspects of Altisidora conform to the archetype of beauty: she says that she is fifteen years old and has long blond hair. However, she also admits to other features:

Aunque es mi boca aguileña

y la nariz algo chata

ser mis dientes de topacios

mi belleza al cielo ensalza

(And though my mouth is aquiline

and my nose is rather blunt,

I have teeth of topaz, raising

my beauty up to high heaven $)^{77}$

With her self-description, Altisidora twists the stock images of Petrarchan lyric. Noses, not mouths, are aquiline, and teeth are supposed to resemble white pearls, not yellow topaz. Altisidora's song represents her as an equivocal object of desire, equal parts beautiful and monstrous.

Part of the punishment Altisidora's chivalric theater imagines for Don Quixote is the confrontation of a fun-house mirror version of the ideal chivalric woman, the same punishment that awaits knights who fall for the deceptive beauty of the enchantress. Moreover, Altisidora's song reveals an awareness of the twisting of chivalric femininity in Part I. Her song echoes Don Quixote's dubious blazon of Dulcinea:

Sus cabellos son oro, su frente campos elíseos, sus cejas arcos del cielo, sus ojos soles, sus mejillas rosas, sus labios corales, perlas sus dientes, alabastro su cuello, mármol su pecho, marfil sus manos, su blancura nieve, y las partes que a la vista humana encubrió la honestidad son tales [...] que solo la discreta consideración puede encarecerlas, y no compararlas. (Her tresses are gold, her forehead Elysian fields, her eyebrows the arches of heaven, her eyes suns, her cheeks roses, her lips coral, her teeth pearls, her neck alabaster, her bosom marble, her hands ivory, her skin white as

76 Vickers, 'Diana Described', 265-66.

77 Cervantes Saavedra, Don Quijote, II, 44; 374. 
snow, and the parts that modesty hides from human eyes are such [...] that the most discerning consideration can only praise them but not compare them. $)^{78}$

Quixote's catalog is grotesque and clichéd, and his mention of the parts of Dulcinea hidden by clothing sexualizes her in a way that breaks Petrarchan decorum. Altisidora plays with the blazon much in the same way, invoking it at the edge of poor taste.

It is likely that Altisidora, having read or heard Part I as a member of her mistress's domestic circle, deliberately parodies Quixote's description of Dulcinea. Don Quixote might be offended at what this implies about his own poetic talents, or he may react badly to Altisidora because she serves as an unwelcome reminder of Dulcinea's (or perhaps Aldonza's) faults. Like her mistress, Altisidora participates in the reconsideration of the ideal of Dulcinea in Part II of Don Quixote. Altisidora implies a comparison between herself and Dulcinea by applying the blazon in this way, and perhaps Dulcinea is even the loser in the equation. Part of the discomfort of this juxtaposition may be Quixote's fading memory of an illiterate Aldonza/Dulcinea, who likely would not be able to perform a layered literary pastiche.

Altisidora's references to clothing, moreover, have a resonance beyond their metonymy with body parts. Sewing and weaving feature prominently in early modern discourse about women's lives, often alongside injunctions against reading for entertainment. Every episode involving Altisidora, including all her songs and speeches, contains at least one reference to the manufacture of textiles. Conduct books urged even women of high status to avoid sinful leisure by keeping their hands occupied in spinning, weaving, and sewing; Isabel la Católica, for example, learned embroidery as part of her early education. ${ }^{79}$ Altisidora imagines gifts for Don Quixote that would be within the realm of her daily experience. However, Altisidora's constant occupation has not answered the conduct books' promise, as domestic tasks have not prevented her from absorbing literary culture or imitating chivalry.

Many early modern writers combine descriptions of needlework and reading, suggesting that these are emblematic activities for women of the bourgeoisie and upper class. Juan Luis Vives mentions reading and spinning in the same sentence: 'She will learn, together with reading, how to work with wool and flax, two arts passed on to posterity from that former age of 
innocence. ${ }^{80}$ For Fray Luis de León, sewing and weaving are wholesome substitutes for reading chivalry, poetry, or letters. ${ }^{81}$ Perhaps ironically, Feliciano de Silva's chivalric version of a conduct book also combines treatment of reading and needlework. In Florisel de Niquea Part IV, the female characters gathered in Sinestasia's magical castle spend their evenings discussing women's education. They write a book called the Ornamento de princesas (The Ornament of Princesses) that encourages girls to learn four skills: leer, escrevir, rezar y labrar (reading, writing, praying, and needlework)'. ${ }^{82}$ Silva's characters offer no further detail on reading, but they represent needlework as the woman's equivalent of masculine prowess in battle. Their daughters should beautify household objects through embroidery 'ansí como los Cavalleros hermosean los campos con los cuchillos derramando sangre (just as the Knights make the fields more beautiful with their blades dripping blood), ${ }^{83}$ Even Silva, a chivalric writer known for his ludic sensibility and eroticism, depicts the ideal woman in a gender-segregated domestic circle, spending her days with a needle and thread.

In Part I of Don Quixote, Dorotea's narrative likewise pairs the concepts of sewing and reading. She tells Cardenio, the barber, and the priest that her leisure activities consist of 'la aguja y la almohadilla, y la rueca muchas veces (the needle and pincushion, and at times, the distaff)' and the reading of 'algún libro devoto (a book of devotions), ${ }^{84}$ Only later, when it proves convenient, does Dorotea admit to reading chivalry. For Christine GarstSantos, 'Dorotea represents the female subject whom Vives and Fray Luis fear and seek to contain: a woman who understands that, while the conduct manuals may offer a very limited set of norms for self-fashioning, anyone can manipulate the norms in order to remake themselves'. ${ }^{85}$ Like Dorotea, Altisidora cites the conduct tradition and twists it to her own purposes. While Dorotea is concerned with establishing herself as a young woman of virtue, Altisidora plays for laughs the basic assumption conduct writers make about female readers - that they use the romance of chivalry as a guidebook for sexual license.

Many didactic writers of early modern Spain follow the tradition of Erasmus in their recommendations, whether or not they cite his texts explicitly. According to J. K. Sowards, Erasmus recommends that women

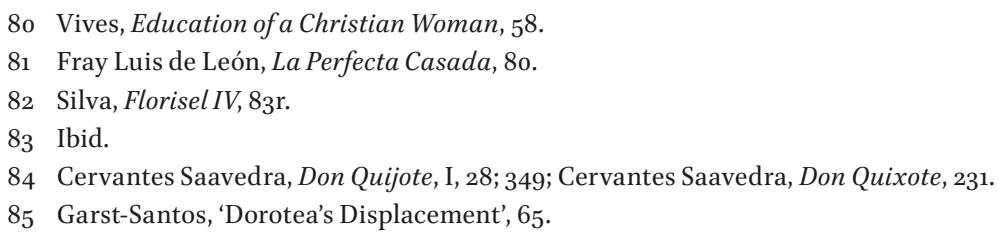


read only 'the literature of the church and the church fathers, with the ancient classical moralists appended'. ${ }^{86}$ Erasmus opposes all forms of idleness for both men and women. For him, virtuous reading has the potential to shield the mind, but fictional reading, an idle pursuit, poses a danger. ${ }^{87}$ Elizabeth Spiller writes that for Vives, the most famous Erasmian humanist from the Iberian Peninsula, 'readers' responses to [romances of chivalry] are inherently immoral because they result from the passion produced by reading., ${ }^{88}$ Alexio de Venegas equates books of chivalry with go-betweens: 'Vemos que veda el padre a la hija que no le venga y le vaya la vieja con sus mensajes, y por otra parte es tan mal recatado que no le veda que leyendo amadises y esplandianes con todos los de su bando le esté predicando el diablo a sus solas (We see that the father prohibits the old woman to go back and forth to his daughter with her messages, and by the same token it is just as unseemly if he does not prohibit that she read Amadíses and Esplandianes and all the others of that ilk, through which the devil preaches to her in her solitude): ${ }^{89}$ Venegas seems to have taken literally the famous episode from Dante's Inferno in which Francesca da Rimini explains that reading the prose Lancelot inspired her and Paolo Malatesta to commit adultery. ${ }^{\circ}$ This view of the dangers of reading had a high degree of diffusion in Golden Age Spain. When Altisidora pretends to be love-struck over Don Quixote, she parodies the lascivious behavior many didactic writers expected to find in women who read books of entertainment.

Quixote appears to share the anxiety of the didactic tradition about female readers of chivalry. In reply to Altisidora, he recommends sewing as a remedy against love:

Suelen las fuerzas de amor sacar de quicio a las almas tomando por instrumento la ociosidad descuidada Suele el coser y el labrar y el estar siempre ocupada ser antídoto al veneno de las amorosas ansias.

86 Sowards, 'Erasmus and the Education of Women', 79.

87 Ibid., 83 .

88 Spiller, 'Cervantes', 296.

89 Venegas, 'Prólogo al lector', 81; Menéndez y Pelayo, Orígenes de la novela, 1: 267.

90 Dante Alighieri, The Divine Comedy, 5: 127-38. 
Las doncellas recogidas

que aspiran a ser casadas

la honestidad es la dote

y voz de sus alabanzas.

(Often the power of love

can madden a maiden's soul,

using as its means, its instrument,

an unthinking leisure and ease.

Fine sewing and needlework,

constant devotion to labor,

can be the cure, the antidote,

to the poison of love's disease.

For sheltered and modest maidens

who aspire to be married,

chastity is the best dowry,

the best voice to sing their praises. $)^{91}$

Quixote reprimands Altisidora for ociosidad, the idle condition Erasmians feared. Idleness leads, according to Quixote's ode, to libertine behavior. Altisidora does not hear the reproof alone; the duchess, the duke, and the ladies of the house are listening, and they have prepared a response to Don Quixote in the form of a sack of cats with bells tied to their tails. Cats, hunters of household vermin, are appropriate agents for the women's vicarious revenge. Moreover, Quixote earlier implied a comparison between women and animals when he urged Sancho, in his new governorship, to resist the complaints and gemidos ('whimpers') of beautiful women. ${ }^{92}$ The confinement of the cats in the sack and their recourse to claws and teeth serves as a metaphorical representation of the women trapped in the domestic sphere. The women, including the duchess, enact similarly petty violence on each other, on Don Quixote, and on Sancho. The duchess and Altisidora beat Doña Rodríguez with a slipper and pinch Don Quixote, and the dueñas of the household prick Sancho Panza with pins. ${ }^{93}$

Quixote's indifference to Altisidora appears to discomfit her, though Cervantes never makes clear what response she desires from the mad knight. In her second song, she takes on the pose of the unrequited lover, calling

91 Cervantes Saavedra, Don Quijote, II, 46; 384; Cervantes Saavedra, Don Quixote, 754-55.

92 Cervantes Saavedra, Don Quijote, II, 42; 359. The word gemir can be applied to sounds made by many animals, including cats and dogs.

93 Ibid., II, 48; 403, II, 69; 560-61. 
Quixote a monster and comparing him to 'Cruel Vireno, fugitivo Eneas (Vireno most cruel, [...] fugitive Aeneas)'. ${ }^{44}$ Though Iberian romances of chivalry contain many examples of women scorned, Altisidora chooses Virgil's Dido, who, like the Cervantine character, is an ambivalent figure. In Virgil, Dido is sympathetic for her pain, but her disappointment and eventual suicide are necessary sacrifices to Trojan (and masculine) progress. Altisidora evokes her and Olimpia of Orlando Furioso, abandoned to die by her cruel husband, Bireno, to imply that Quixote is guilty of similar cruelties to women. Part I, meanwhile, is another intertext for Altisidora's song, as it depicts cruel men who abandon women to ignominious fates, most prominently Dorotea's seducer, Fernando.

Altisidora pairs her literary allusions with the accusation that Quixote has stolen 'tres tocadores / y unas ligas (de unas piernas / que al mármol puro se igualan en lisas) blancas y negras (three nightcaps / and garters both black and white / from legs that rival the purest / marble in their smoothness)'. ${ }^{95}$ These articles of clothing, especially the intimate garters, are female counterparts for the male clothing enumerated in the first song. In chivalric romance, ladies often give their knights a token to signal their acceptance of his service. In Amadís de Gaula, Oriana offers Amadís a ring, and in Las sergas de Esplandián and Cristalián de España, princesses send the titular characters valuable jewels as pledges of favor. These small items of clothing are tokens a servant like Altisidora can afford, and she would likely have made them herself.

The reference to garments made as part of a woman's domestic employment indicates that Altisidora and Quixote are negotiating not a love affair, but a set of beliefs and practices that determine the ways in which women are allowed to spend their time. The duchess was unaware that Altisidora had planned this second song: 'Quedó la duquesa admirada de la desenvoltura de Altisidora [...] no estaba advertida desta burla (The duchess was amazed at the boldness of Altisidora [...] since she had not been told about this joke). $\cdot{ }^{6}$ The duchess's authority is among the power structures Altisidora's performance seeks to contest. Altisidora's final appearances in the novel, moreover, stage both her defeat and her vindication. Whether the duchess and Golden Age society succeed in taming her is left unclear. 


\section{The Death and Resurrection of Altisidora}

Quixote leaves the ducal estate for several chapters and returns to a final spectacle, that of Altisidora dead of love on his account. The final ducal marvel is a complex set piece that involves both male and female servants and evokes many intertexts, including the myth of Orpheus and Eurydice, Aeneas's meeting with Dido in the underworld, Dante's Inferno, and the funeral of Grisóstomo in Part I. ${ }^{97}$ Altisidora, the central figure of this tableau, becomes an inscribed reader of all the intertexts her performance activates: her knowledge of them must have some source in reading or listening. When Altisidora regains consciousness after the dueñas attack Sancho, she levels at Don Quixote Garcilaso's famous line: 'Oh más duro que mármol a mis quejas (Oh, harder than marble to my complaints)'. ${ }^{9}$ Yet Altisidora seems to have grown tired of love, and she wounds Don Quixote in a new way by turning the conversation to his reputation as a literary character. In the ducal episode, Quixote and Sancho have been treated as incarnations of their book, circulating in a metaphorical literary market. From Chapter 59 onward and in the prologue, Cervantes also reacts to the publication of Fernández de Avellaneda's unauthorized second volume. ${ }^{99}$ Avellaneda's sequel is not a concern during the initial ducal episodes, but it is very much at issue during Quixote's second visit to the estate. Indeed, the combination of the figure of the sequel writer with the hostile ducal reading communities in this episode implies that, for Cervantes, all readers are potential 'writers' with the ability to twist and distort their reading materials to suit their own performative needs. For the same sin as a hack sequel writer-malicious and self-serving reading practices-Altisidora has been sent to hell.

In Altisidora's description of the underworld, books stand in for people, and bad books are punished in the place of sinners. Altisidora claims that she did not enter into hell proper, but rather stood watching a literary spectacle outside the gate:

97 Jehle, 'The Resurrection of Altisidora', 10-12.

98 Cervantes Saavedra, Don Quijote, II, 66; 545 . Here, the verse occurs as part of what Edward Dudley terms a farewell to the pastoral world. See Dudley, 'O mas dura', 30. Altisidora's citation of Garcilaso is part of a dense network of references to the poet. Jorge Aladro-Font and Ricardo Ramos-Tremolada identify fifteen references to Garcilaso in Part II in 'Ausencia y presencia de Garcilaso en el Quijote', 89-90.

99 Though the first direct mention occurs in Chapter 59, Montgomery argues that Cervantes may have learned of the illegitimate sequel as he was writing Chapter 58 . See Montgomery, 'Did Cervantes Learn of Avellaneda's Quijote Earlier than Chapter 59 of Part Two?', 11. 
Llegué a la puerta, donde estaban jugando hasta una docena de diablos a la pelota, todos en calzas y en jubón, con valonas guarnecidas con puntas de randas flamencas, y con unas vueltas de lo mismo, que les servían de puños, con cuatro dedos de brazo fuera, porque pareciesen las manos más largas; en las cuales tenían unas palas de fuego; y lo que más me admiró fue que les servían, en lugar de pelotas, libros, al parecer, llenos de viento y de borra. (I reached the gate, where about a dozen devils were playing pelota, all of them in tights and doublets, their collars trimmed with borders of Flemish lace and cuffs of the same material, exposing four fingers' width of arm so that their hands appeared longer, and in them they were holding bats of fire, and what amazed me most was that instead of balls they were using books, apparently full of wind and trash.) $)^{100}$

Altisidora's description of hell as a place with a gate and a region outside it recalls Dante's Inferno. In Dante, the ambivalent, those who chose neither good nor evil, are condemned to spend eternity outside Inferno's gates. They mix with those angels who neither obeyed nor rebelled: 'The heavens reject them so as not to be less / beautiful, nor does deep Hell receive them, for the / wicked would have some glory in them [...] The world permits no fame of them to exist'. ${ }^{101}$ Like the ambivalent angels, the poorly written books are of indeterminate status, unworthy of literary fame or even of a stable place in hell. Altisidora's description of the devils again pays attention to men's clothing, this time collars and sleeve-cuffs made of lace. The devils have their wrists exposed to make their hands look longer, as did the dueñas who pricked Sancho. ${ }^{102}$

Altisidora's anecdote about the books recalls the story of the madman and the dog in the prologue to Don Quixote Part II, in which a madman hesitates to drop a stone on any dog, remembering the moment when he was criticized for dropping a stone on a hound. Cervantes follows this enigmatic fable with a comment about sequel writer Avellaneda: 'Quizá de esta suerte le podrá acontecer a este historiador, que no se atreverá a soltar más la presa de su ingenio en libros que, siendo malos, son más duros que las peñas (Perhaps something similar may happen to this storyteller, who will not dare ever again to set his great talent loose among books, which, when they are bad, are harder than boulders)'. ${ }^{103}$ In the madman story, the

100 Cervantes Saavedra, Don Quijote, II, 70; 566; Cervantes Saavedra, Don Quixote, 915.

101 Dante Alighieri, The Divine Comedy, 2:40-42, 49.

102 Cervantes Saavedra, Don Quijote, II, 69; 560.

103 Ibid., II, 36; Cervantes Saavedra, Don Quixote, 457. 
stones represent books, and the dogs the reading public. Some books are only appropriate to drop on certain publics; other books, like Avellaneda's, are not appropriate for anyone. Altisidora's vision of hell has shown her the fate of the bad writer. Avellaneda's Quixote serves as one of the balls in the game Altisidora witnesses. One devil levels at it a diabolical sort of praise, calling it 'tan malo [...] que si de propósito yo mismo me pusiera a hacerle peor, no acertara (So bad [...] that if I myself set out to make it worse, I would fail)'. ${ }^{104}$ What is most puzzling about this description is that Altisidora, a woman of uncertain literacy status, should have journeyed Dante-like to the site of literary punishment.

Altisidora's association in hell with the apocryphal sequel writer reveals that what is at stake in the ducal episode is the power of the reader. A sequel writer, especially a bad one, is a proven reader with a concrete interpretation of a text, and thus can serve as a straw man for complaints about the way reading can twist and pervert an author's creation. By placing herself among the ambivalent and among the bad books, Altisidora declares that she is not in love with Don Quixote. If her sin were lust, she would have taken up a place with Francesca, Paolo, and Dido in the second circle. If she has sinned, she has sinned as a figure of the writer; her performance of chivalric trope did not convince Don Quixote. The duchess's ladies, especially Altisidora, are inscrutable as consumers of literary culture. How do they benefit, or hope to benefit, from imitating chivalry? Do they truly relish cruelty, or is it merely their response to being trapped, like the cats, in a repressive environment? The answer is likely different for each woman.

Don Quixote, frustrated with the entire reading community, utters a final condemnation for Altisidora's behavior not to the girl, but to the duchess. Perhaps he means for the mistress as well as the servant to follow his advice:

Todo el mal desta doncella nace de ociosidad, cuyo remedio es la ocupación honesta y continua. Ella me ha dicho aquí que se usan randas en el infierno; y pues ella las debe de saber hacer, no las deje de la mano; que ocupada en menear los palillos, no se menearán en su imaginación la imagen o imágines de lo que bien quiere.

(All the problems afflicting this maiden are born of idleness, and the remedy lies in honest and constant labor. She has told me that they use lace trimmings in hell, and since she must know how to make them, she should never let them out of her hands; if she is occupied in moving the 
bobbins, the image or images of what she desires will not move through her imagination.) $)^{105}$

Don Quixote returns to the strictures of the conduct book for his final comments. Perhaps the next time Altisidora goes to hell, she can offer the literary devils an appropriate gift.

Quixote's words seem particularly cruel given that it is not in Altisidora's power to change her own life. It is up to the duchess to decide whether Altisidora works or is idle, or whether she eventually gains any sort of independence. The entire reading community, starting with the primary readers, must address the problem of ociosidad ('idleness') and dedicate themselves to different pursuits if Quixote's commands are to be followed. Perhaps ironically, obeying Don Quixote the character would remove the entire community from the virtual audience for Don Quixote the book. The question remains of whether Cervantes would consider his other female characters - perhaps Luscinda or Dorotea rather than the duchess or Altisidora-ideal readers of his work, or whether the true ideal is in fact the illiterate Dulcinea. Don Quixote contains many female characters steeped in literary culture, which seems to indicate that Cervantes imagines women among his audience, but their status, like that of the bad books in Altisidora's hell, is ambivalent.

The key to understanding Quixote's regressive position on women's reading at the end of the novel is its timing. The resurrection of Altisidora occurs at the midpoint between Quixote's defeat at the hands of Sansón Carrasco and his death. ${ }^{106}$ The fortunes of women and of chivalry fall with Don Quixote's return to sanity. It is possible that Cervantes uses the ducal sequence to solidify his critique of chivalry, that most base and corrupt of literary genres. However, this reading would require us to rejoice at Don Quixote's death. At least in part, extradiegetic readers are meant to feel a sense of loss at the return to conventional standards for female behavior, just as we feel the shock of Quixote's demise. Furthermore, it seems likely that Don Quixote's condemnation of the woman reader is his own, an opinion that departs from that of the author.

Altisidora, unsympathetic though she may be, mirrors Cervantes in the complexity of her literary references and in her ludic imitations of those texts. Perhaps with the servant girl, Cervantes is suggesting that the most expert readers are not necessarily the most privileged. Though Altisidora 
joins Avellaneda briefly in hell, she is resurrected thereafter, to the words of Garcilaso ${ }^{107}$ While Altisidora's death models the exclusion of women readers, her resurrection suggests their resurgence. Though the romance of chivalry was crafted for an aristocratic male audience, the new genre that would coalesce into the modern novel, represented by Parts I and II of Don Quixote, directs itself to a wider public that ultimately includes readers like Altisidora. Don Quixote the character expresses discomfort with his readers throughout Part II, and perhaps his antipathy for Altisidora merely reflects a general stance against readers of either gender. Cervantes, however, is not as anti-reader as his character, especially when reading has the potential to break class barriers. The final glimpse of the ducal palace reduces the duke and duchess's participation in favor of that of their servants, especially Altisidora. The duchess recites no poetry and visits no imaginary landscapes, hellish or otherwise. Her preferred genre - the romance of chivalry - and the hierarchy-reinforcing principle with which she administers it to her reading community are part of the past, both for Part II of Don Quixote and for Golden Age Spain. In the end, Cervantes hints that the resurrected Altisidora, a figure of the newly emancipated bourgeois and lower-class readers of the print era, should move beyond Amadis and other artifacts crafted by and for the nobility. Instead, she should read the book in which she appears, which stages her revolt and her survival:Don Quixote, the most durable Iberian echo of Amadis de Gaula.

107 Just before Altisidora stirs, a musician sings the second octave of Garcilaso's Égloga III (II, $69 ; 559)$. 



\section{Conclusion}

Soy mujer y escribo.

Soy plebeya y sé leer.

Nací sierva y soy libre.

(I am a woman and I write.

I am a commoner and I know how to read.

I was born a serf and I am free.)

- Rosa Montero, La historia del rey transparente ${ }^{1}$

This book has traced the fates of women characters in chivalric romance along an intertextual pathway that reaches from Amadís de Gaula, a work of the late medieval period, through Don Quixote, Spain's first modern novel. The letter writers and wise women of Amadís and Cristalián de España indicate that in the first half of the sixteenth century, writing and reading, though controversial activities, provide fictionalized women a means of acting on the world by proxy, thereby circumventing conventional restrictions on their behavior. Cristalián de España, published at the beginning of chivalry's decline in Spain, shows how one specific female reader, Beatriz Bernal, finds in her chosen genre the blueprints for women's agency and self-expression. Cervantes, writing at the end of Iberian chivalry's long, slow fall from prominence, recovers many of these same genre tools through his inscribed women readers. Though in Part II Cervantes guides his literate women away from chivalric romance to genres of more prestige, including lyric poetry and the emergent novel, in the world of Don Quixote, chivalry still has an emancipatory role to play for women, serving as a bridge towards the kinds of creative, transformative intertextual practices that writers of the Renaissance celebrated. Throughout this journey, acts of writing and reading have served as an index for women's self-awareness and drive to act on their own behalf. Though women's autonomy in early modern fiction is always conditional, it becomes more possible when women characters perform or write texts. Literate female characters have the potential to resist or to decide, and though they sometimes reaffirm an existing social order, they may also work to transform it. 
The link among female characters, acts of writing, and chivalric trope outlives the early modern period in Spain. Chivalric romance has undergone periodic resurgence from the seventeenth to the twenty-first century, and some of the woman-friendly features of the genre persist today, especially in genre fiction from Spain and other countries. For just one example, the Lady of the Lake, who makes a cameo appearance in most of the foregoing chapters, is the landmark literate woman of medieval chivalry, and she continues to surface in works of contemporary high fantasy in many linguistic traditions. The priestess Viviane of Marion Zimmer Bradley's well-known The Mists of Avalon (1983) shows off an American use of the figure, while Ana María Matute's stern, grandmotherly Dama del Lago of Olvidado Rey Gudú (Forgotten King Gudu, 1996) offers a contemporary Spanish take. This chapter examines a neo-chivalric novel that features yet another Lady of the Lake, a version of the character that exploits the sorceress's potential as a product of intertextual crossings. Rosa Montero's 2005 La historia del rey transparente (The Story of the Transparent King) blends chivalric and historical sources in an exploration of a fictionalized medieval woman's emergent literacy and agency. Even in 2005, at the outset of a new millenium, a medieval and early modern literary form speaks to an author invested in women's experience. For Rosa Montero, a female knight's awakening to literary culture is just as important, and just as emotionally affecting, as her experiences in love and combat. Montero's Leola does not enjoy a happily ever after, but she does succeed at the twin vocations of arms and letters, rendering invalid for the twenty-first century chivalric motifs that silo men and women into archetypal active and passive roles.

For Montero's novel of the Middle Ages, historical accuracy is less important than establishing contact between Leola and medieval personalities that embody the modernizing features of the era. Montero's text might be considered neomedieval, following Humberto Eco's use of the term, as it fuses research on the period in which the novel is set with original material that reflects the author's own time period and worldview. ${ }^{2}$ La historia del rey transparente 'reads' both the past and the present, and the story of Leola and her twin initiation into the worlds of military action and literacy shows that chivalric romance continues, even after the rise of the modern novel, to offer a viable literary format in which to debate gender politics. Leola, Nyneve, and their Cathar allies ultimately fail to resist the pressures that surround them, and in fact, few of Montero's characters survive to the end of the volume. 
Rather than merely placing a modern woman of modern sensibilities in a medieval setting, Montero uses existing medieval and early modern building blocks, many of them from chivalric romance, to craft her female characters and their stories. The result is a work of fantasy built from historical and fictional relics - a medieval novel that, while historically inaccurate, harmonizes with its setting. While Montero's novel is more progressive on women's issues than any of the early modern texts I have discussed, its events are not a radical departure from the possibilities of chivalric fiction. Montero, herself a reader of the genre, reinterprets it for a modern, mixed-gender public. Montero is the last in the chain of women readers of chivalry this book has discussed, and fittingly, she is the one whose literary production illustrates most clearly the intimate tie between the reading of romance, the expression of women's interior lives, and the creation of fictional worlds in which women are free to maneuver.

\section{Montero's Feminist Romance of Chivalry}

As Sara Fernández Medina observes, Montero hesitates to describe herself as a feminist in interviews, but I join Pilar Nieva and Victoria Rivera-Cordero in noticing Montero's persistent interest in gender and in the self-actualization of women characters. ${ }^{3}$ In her postface to the novel, Montero describes $\mathrm{La}$ historia del rey transparente, which sends its protagonists wandering through the courts, debates, and battlefields of twelfth-century France, as a novel of 'las aventuras y lo fantástico (adventures and the marvelous)' rather than as a historical novel or as a feminist novel. ${ }^{4}$ For me, it is a novel of adventures built on a framework of research in both historical and fictional sources, and the result is more poignant than a strictly historical novel would be, as the author creates coincidences for an artistic purpose. The protagonist, Leola, is a twelfth-century French serf who becomes separated from her father, brother, and fiancé in the aftermath of a battle between local lords. She takes up the armor of a fallen soldier and pretends to be a man in order to keep herself from danger. When she fails in the attempt, the quixotic Pierre (alias San Caballero) rescues her and instructs her in the knight's altruistic vocation. Leola then partners with Nyneve, an overt figure of the Lady of the Lake, who claims to be a 'bruja de conocimiento (witch of knowledge)' and

3 Fernández Medina, 'Más allá de las palabras', 83; Nieva de la Paz, 'Modelos femeninos de ruptura', 122; Rivera-Cordero, '“El mundo fue un milagro"', 125.

4 Montero, Historia del rey transparente, $5^{8} 5$. 
to hail from the magical isle of Avalon. ${ }^{5}$ Together the two women become warriors in truth, fighting as mercenaries in a twenty-five-year journey across southern France.

Leola and Nyneve cross paths with several historical figures, including Eleanor of Acquitaine, her daughter Marie de Champagne, writer of Arthurian lais Marie de France, theorist of courtly love Andreus Cappellanus, nun and encyclopedia writer Herrade de Landsberg, and even Héloise, in the years after her affair with Abelard. Leola reports that chivalric author Chrétien de Troyes, alas, was not with his patron Marie de Champagne at Eleanor's court at Poitiers, and thus she misses her chance to meet him. ${ }^{6}$ The figures Montero collects are roughly from the same century, though their timelines do not intersect as they do in the novel. Montero describes her approach to history as 'uchronic', a temporal version of utopian. ${ }^{7}$ In Montero's words, the episodes and personae she selects from medieval French history reflect the 'protodemocracia y modernidad (protodemocracy and modernity)' of the Middle Ages which, as Leola and Nyneve find out to their sorrow, would be defeated by the forces of monarchy and Christian hegemony. ${ }^{8}$

My purpose here, however, is not to evaluate La historia del rey transparente's relationship to history, but rather its argument about women's literacy, which it develops in part through citations, both direct and indirect, of chivalric romance. Among the sources Montero cites in her postface to the reader, only one is fictional, John Steinbeck's The Acts of King Arthur and his Noble Knights (1976), based on Sir Thomas Malory's Le Morte D'Arthur (The Death of Arthur, 1485). Steinbeck's version of Arthur is an adaptation of an adaptation, a remote echo of the medieval French and English texts Malory reinterpreted for English readers of the fifteenth century. Steinbeck's adaptation renders Malory in the matter-of-fact language of the mid-twentieth-century United States. The result is an accurate recital of the events from Malory, modernized only in terms of language. Steinbeck buys into the myth of Arthur, and his impact on Montero's rosy view of Arthurian legend is quite clear. Yet Montero's novel also owes a hidden debt to Iberian romance and to the ideological project of Amadís de Gaula.

Though Montero does not mention Don Quixote or Amadís de Gaula in her text or in her postface, the description of two characters recalls these early modern works. Pierre or San Caballero ('Saint Knight'), an elderly 
gentleman who has left his home to perform deeds of arms on behalf of noble causes, recalls the persona of Don Quixote without the irony or the humor at this character's expense. The character dies soon after saving Leola from unsavory men on the road, and he and his horse are mummified in a cave that recalls Cervantes's Cave of Montesinos, where three personae from medieval ballads experience a living death. San Caballero, like Don Quixote during his repast with the goatherds, laments the fallen nature of the world and longs for the return of the Golden Age, which he defines as the age of Arthur. ${ }^{9}$ Montero plays the character of Don Quixote in a solemn and serious vein, which is wholly surprising for Spanish literature but in keeping with her project of resurrecting the real and imaginary utopian features of the past.

Montero's citation of Amadís is more direct but also more limited in its scope. She uses the word endriago ('monster'), which traces its etymology to the part-man, part-animal Endriago from Book III of Montalvo's Amadis, to describe the deformed body of a Cathar dwarf woman. ${ }^{10}$ Despite the pejorative term, both Montero and her narrator Leola are sympathetic to the many characters in the novel who suffer physical and mental disabilities. For Raúl Diego Rivera Hernández, Leola's advocacy on behalf of the marginalized reflects the author's own ideology. ${ }^{11}$ In fact, one of the featured entries in Leola's dictionary, her magnum opus, is compassion, which she has ample opportunity to practice among her coterie of misfit associates. ${ }^{12}$ Montero's one-word citation of Amadis might be accidental, chosen for its proverbial quality and not its pedigree in Iberian romance. However, Amadis de Gaula, along with Don Quixote, might be part of the fabric of Montero's perception of the Middle Ages, whether or not she is aware of it.

Both Amadis and Don Quixote have long been a part of Spanish school and university curricula, and indeed, it would be difficult to avoid Don Quixote. Montero's project, moreover, has much in common with Amadis de Gaula. Both rewrite the medieval French Arthurian tradition for later eras, though only Montero interpolates chivalric authors Marie de France and Chrétien de Troyes as minor characters. In their general plotlines, the works are Lancelot-influenced coming-of-age stories featuring a young knight of obscure origin and a benevolent female magician who performs a prophetic, scholarly variety of magic. Both are set outside of Spain, in

Montero, Historia del rey transparente, 551. 
Britain and France, respectively, and both discuss Iberian phenomena only through analogy and metaphor. While Montalvo's Amadis might be said to celebrate Fernando and Isabel's conquest of Granada through its battles between Christians and their giant neighbors, Montero's novel reinterprets that same event in a tragic light through her sympathy with the Cathars. The Catholic Church's genocidal effort to eradicate the Cathar heresy was termed a crusade, as was the Reconquest. That Montero's Leola and Nyneve land on the losing side is no accident. Victoria Rivera-Cordero agrees that Montero uses the Cathar heresy as an analogy for conflicts closer to home, though she points to the events of September 11, 2001, the war in Iraq, and the so-called war on terrorism, which was a frequent subject of Montero's $E l$ País articles, as the antecedent for Montero's vision of religious intolerance in France. ${ }^{13}$

\section{Women Readers and Writers in Montero}

Montero's medieval novel takes as its main business the reconsideration of gender archetype and renders literacy an index for women's agency. Myriam Osorio remarks that both of Leola's occupations are masculine pursuits in the Middle Ages and interprets Leola's acts of war and acts of writing through Judith Butler's theory of gender performativity. ${ }^{14}$ In a similar vein, Rivera-Cordero views Leola as a deliberate exception to the medieval norm. ${ }^{15}$ In partial disagreement with Osorio and Rivera-Cordero, I would remark that each of Leola and Nyneve's actions has some medieval or early modern precedent. Rather than being modern women in a medieval world, they are aggregates of the transgressive women, fictional and real, of the past.

Leola, the mercenary and scholar, is an update on the women warriors of the chivalric tradition, including Bernal's Minerva, Ariosto's Bradamante, and Spenser's Britomart. In her rough-and-tumble military life, in which her ambiguous gender presentation attracts both men and women, she also bears some resemblance to the historical Catalina de Erauso (1592-1650). This female soldier, nicknamed the Lieutenant Nun, participated in Spanish campaigns in Perú and Chile and wrote a memoir about her experiences as a means of apology for her crimes against gender roles. ${ }^{16}$ Leola shares

Rivera-Cordero, '"El mundo fue un milagro"', 123

Osorio, 'Sexo y género', no pagination; Butler, 'Performative Acts and Gender Constitution'.

Rivera-Cordero, "'El mundo fue un milagro"', 120.

Erauso, Lieutenant Nun. 
her cross-dressing and her zest for fighting with these medieval and early modern women. Her initial quest, moreover, suggests another link to the fictionalized girl warriors of chivalric romance. Leola leaves home to search for Jacques, her peasant betrothed, and the story does not end until she finds him, long after she has stopped looking.

It is not love or the search for a man, however, that structures Leola's life, as in the case of Bradamante, Britomart, and even Cervantes's Dorotea. Rather, like Bernal's Minerva, Leola appreciates her freedom for its own sake and undertakes many kinds of aventures. ${ }^{17}$ As a young woman, Leola works as a mercenary because she enjoys fighting, and as she ages, she transitions to a more contemplative life. Montero's representation of Leola's scholarly vocation owes a debt to the wise women of chivalric romance. Leola begins by learning the alphabet under Nyneve's tutelage and then becomes a fond reader, first of secular texts, and then of works of theology and philosophy. Upon settling in progressive, Cathar-controlled Albi, she begins teaching children to read and write. Then, inspired by Herrade de Landsberg, she begins to collect words for a highly personal dictionary, one that offers essays on the meanings and uses of words that have become important to her life. While a dictionary might sound detached and quasi-scientific, Leola's version of the genre is an emotional work, a companion volume for her first-person narration.

Indeed, the novel reads like an autobiography, its structure not so different from that of the narrative Catalina de Erauso wrote under papal command. At each stage in her development, Leola pays attention to emotion, both to her own feelings and those of others. While female characters in the chivalric narratives discussed in this book use writing to express their point of view, including their emotions, Leola uses writing to explain how the acts of writing and studying make her feel. As she first experiences formal schooling under Cathar tutelage at Albi, Leola says to the reader: 'Lo que yo ahora deseo es aprender, alcanzar cierta sabiduría, elevar mi alma [...] Estudio retórica, gramática, teología y lógica (What I desire now is to learn, to achieve a certain level of knowledge, to elevate my soul)'.18 One page later, she informs the reader that her position at school has led to a job as a teacher of young boys of the mercantile class: 'Me gusta este trabajo, disfruto dibujando mi versión del mundo en las cabezas de los niños [...] Creo que sería feliz aquí, en mi palacio de sueños y pintura, [...] si no fuera por el fragor cada vez más cercano de la guerra (I like this work, I 
enjoy drawing my version of the world in the minds of children [...]. I think I would be happy here, in my palace of dreams and paint, [...] if it were not for the clamor of war that approaches ever closer)'. ${ }^{19}$ Leola's descriptions of life in Albi are marked by scholarly pursuits and by emotion, signaled by the words deseo, disfruto, and feliz. These are the emotions one might expect to find in a chivalric love affair; Montero applies them instead to a woman's achievements in scholarship.

Leola is not content, however, to study passively and to teach the basics of literacy to children. After she meets two women writers, Herrade de Landsberg and Héloise, during a visit to a convent, Leola decides to write a dictionary. She formulates her project in direct imitation of Herrade's encyclopedic Hortus Deliciarum (Garden of Delights): 'Su pasión por el conocimiento es contagiosa: de repente yo también he tenido la extravagante idea de hacer algún día una enciclopedia, pero escrita en lenguaje popular (Her passion for knowledge is contagious: suddenly I have also had the extravagant idea to make an encyclopedia one day, written in the common language)'. ${ }^{20}$ Again, Leola uses the language of emotion, describing Herrade's pasión. Montero presents here a version of the emotional contamination moralists like Vives attributed to women's literary practices, but in this case, the process is a virtuous one. Leola's choice to imitate Herrade after leafing through Hortus Deliciarum recapitulates the relationship between readership and authorship apparent in other chapters of this book. Leola adapts Herrade's format in a way that makes sense for her life and scholarly process, embracing the vulgar language as a vehicle for the transmission of knowledge, as Bernal did in her proemio. Montero follows the pattern set by other chivalric works in representing narrative authority as something borrowed from intertexts, a transference from past to present via the written word. Here, Leola also begins to resemble the author who wrote the book in which she appears; Montero's postface describes how she found inspiration in historical and chivalric texts, and Leola encounters a similar creative spark through contact with Herrade.

Leola's dictionary also serves to articulate Montero's awareness of the dangers writing poses to a medieval woman. All the words Leola presents to the reader have to do with emotion, and most of the definitions reflect frustration, anxiety, and dread, even if the word being defined usually has a positive connotation. Leola's first definition is esperanza ('hope'), which she describes as a 'pequeña luz que se enciende en la oscuridad del miedo 
y la derrota (small light that burns in the darkness of fear and defeat). ${ }^{21}$ Leola also defines hope, for herself and perhaps for other women, as the act of writing: 'He empezado a coleccionar palabras para la enciclopedia que quizá algún día escribiré. Lo cual es, en sí mismo, un perfecto ejemplo de esperanza (I have begun to collect words for the encyclopedia which perhaps one day I will write. Which is, in itself, a perfect example of hope), ${ }^{22}$ Other prominent entries, sorrow (pesadumbre) and compassion, describe responses to suffering, either Leola's own or that of others. Leola's dictionary, in fact, mostly serves to explain the character's emotions to the reader, and it tracks the slow defeat of the Cathars and the end of Leola's independence. The dictionary is less a writing project meant for public consumption than an exploration of interior psychology. In a novel that contains much action, narrated by a woman less outwardly sentimental than Oriana, Luscinda, or even Altisidora, this sort of dictionary might surprise the reader. However, it reveals Montero's understanding of her chivalric and historical source texts as genres in which women's emotional lives are important and should be explored through writing. The dictionary also marks the limits of literacy's emancipatory potential for the medieval woman. It will never be finished, as Leola's enemies find her too quickly, and it has no inscribed readers within the volume.

Indeed, as Montero's novel draws to a close, male-dominated social structures conspire to silence all women. Leola wonders from time to time if she will be burned for heresy for cross-dressing or for associating with Cathars, and everywhere the titular story of the Transparent King haunts her. This fable brings disaster to all those who hear or recite it, and Montero reveals it to the reader piece by piece, including the fullest version only in an appendix. Even this text is not complete; perhaps Montero wishes to save her reader from the calamity that follows any time a person reaches the end of the story. The fable, moreover, reveals itself in Montero's appendix to be about language as a form of resistance. The Transparent King of the title, who, as Rivera-Cordero points out, is known for suppressing his critics, faces a dragon and must answer a riddle: 'Cuando tú me nombras, ya no estoy (When you name me, I am no longer there).. ${ }^{23}$ The answer to this riddle is silence, and Montero signifies it in the text by cutting off mid-sentence and ending the book with a blank page. The work's open ending, which requires the reader to supply the answer, resists literary convention, just as 
Leola resisted the strictures of her society through her writing. Leola never hears the full riddle, but her ignorance does not save her from defeat. As the forces of the Catholic Church close in on her, she lives the riddle's worst consquences, and her death ensures her silence.

The riddle has a second, more optimistic function, however, as its cooperative nature draws Montero and her extradiegetic reader into a partnership that parallels in some measure the extraordinary female friendship that provides much of the joy in the novel. Leola's literary activities and, indeed, the frequent discussion of literature and writing in Montero's novel, owe much to Nyneve, a figure of the wise woman who resembles the chivalric sorceresses depicted in this book. Montero's Nyneve is a hybrid figure, inspired by Malory and Steinbeck's character by the same name, the Lady of the Lake, and, humorously, Sancho Panza. Montero introduces Nyneve in a sylvan setting that seems alive with magic. Caught in the branches of a tree like the infantina ('little princess') of the medieval Spanish ballad, she asks Leola to free her. Nyneve claims that the Vieja de la Fuente ('Old Lady of the Fountain') trapped her with magic, but the crone, waiting nearby, claims that Nyneve has merely ensnared herself while climbing. ${ }^{24}$ Later, Nyneve impresses a group of townspeople by seeming to read their minds; she refuses to tell a wide-eyed Leola whether she has performed an act of divination or whether she has a local informant in her employ. Nyneve's magic, which she alternately affirms and disavows, remains a point of ambiguity throughout the book.

Nyneve, like the Lady of the Lake, takes charge of her protégée's initiation into the life of a knight. She adopts the guise of Nyne, squire to Leola, and her stocky figure, comical appearance, and common-sense advice recall Sancho Panza. Nyneve guides Leola to a master swordsman, named Roland in yet another echo of chivalric romance, who teaches her to overcome the inherent challenges of fighting against men. Leola learns to use her speed and lightness to her advantage, and when she is ready, Nyneve takes her to her first tournament and provides advice on managing her equipment and reading her opponents. After the tournament, Leola becomes more independent from Nyneve, but the two maintain their companionship, setting up household after household together. In masculine dress, Nyneve fights alongside Leola, and in feminine dress, she serves Leola and her rotating household as a healer, in further connection to the Lady of the Lake. As they put down roots in Cathar territory, Nyneve begins painting murals of Avalon, her alleged homeland, on the wall of every dwelling, a humble 
ekphrasis that recalls the more ornate decorations characters encounter in the palaces of chivalric romance.

Nyneve's paintings offer a visual counterpoint for Leola's dictionary. Like Leola's definitions, Nyneve's visions of her real or imaginary island draw specifically on the emotions. When she creates the first one at Albi, Nyneve remarks to Leola: '¿No percibes su fuerza? La mera contemplación de esta pintura produce calma y gozo (Can you not perceive its strength? The mere contemplation of this painting produces calm and delight)'. ${ }^{25}$ Leola agrees: 'Los trampantojos de Nyneve me endulzan el ánimo (Nyneve's illusions sweeten my mood)'. ${ }^{26}$ Yet, as with the dictionary, the emotions Nyneve paints slide into despair. Her final painting of Avalon, created in the tower where both women die, reflects her view of the world as an 'isla de infelicidad (island of unhappiness)' in which she is trapped, separated from the infinite gozo ('delight') of Avalon. ${ }^{27}$ Nyneve's paintings offer what William Reddy terms an 'emotional refuge', a ritual of resistence against social and emotional norms. ${ }^{28}$ However, as with other escape valves, the paintings are at best a temporary bulwark against disaster.

Nyneve's Avalon, real or imagined, is also key to understanding this character as a product of intertextuality. Nyneve claims to be immortal and to know Arthur, Guinevere, Lancelot, and Gawain personally. ${ }^{29}$ As with Nyneve's magic, Montero maintains a studied ambiguity over Nyneve's true nature. It is plausible that the character is, indeed, an Arthurian persona, but doubt creeps in early in the novel, when Nyneve teaches Leola to read with Wace's twelfth-century Roman de Brut. The references to chivalric reading suggest perhaps that Nyneve knows Arthur and his knights only through their representations in books. ${ }^{30}$ Nyneve explains to Leola, however, that she and Viviana, the Lady of the Lake, are one and the same, and that she has been falsely accused of deceiving and entrapping Merlin. ${ }^{31}$ Leola at first accepts this account at face value, but years later, she begins to doubt her friend, reasoning that Nyneve might have fashioned her biography in this way to wield greater influence over her naive protegée.

Nyneve is a product of reading, both intradiegetic and extradiegetic. Montero has clearly shaped her in consultation with sources, and Nyneve has

28 Reddy, The Navigation of Feeling, 129. 
quite possibly remade herself through her own reading. Nyneve and Leola are both inscribed readers of the Arthurian tradition, though not of Montero's precise source, as it is much more modern than the twelfth-century setting of the novel. Montero's Arthurian references draw on Steinbeck's The Acts of Arthur, and to understand Nyneve, it will be useful to examine Steinbeck's use of the character by that name. In Steinbeck's retelling of Malory, the Lady of the Lake and Nyneve are distinct characters. Nyneve is a damsel of the Lady of the Lake who uses Merlin for his magical teachings and then seals him into a cave for all eternity. ${ }^{32}$ This Nyneve repents of her actions as she grows older, and her final mention in the Steinbeck novel has her consoling Sir Pelleas - magically - for his unrequited love and then spending the rest of her life at his side. ${ }^{33}$ Steinbeck's Nyneve is a decidedly minor character who embodies many of the negative aspects of chivalric women's reputation. She is deceptive, superficial, cruel, and initially indifferent to the suffering of others. She does earn a degree of redemption through her love for Sir Pelleas, which Steinbeck does not develop in detail.

Montero reforms Steinbeck's figure, making her both more emotionally compelling and more tragic. Montero does not choose a rosy, heteronormative finale for her Lady of the Lake. While Leola adds compassion and happiness to her dictionary, Nyneve creates what she terms a magic potion to transport her to the Avalon she has painted in her last mural. Leola, still undecided as to whether Nyneve is a true enchantress, tries in vain to stop Nyneve from ending her life. Nyneve takes the potion, and a grief-stricken Leola places Nyneve's inert body, which she calls a cáscara ('shell') or espejismo ('illusion') into the river, hoping that it will thereby reach Avalon. ${ }^{34}$ The burial by water recalls, perhaps by accident, Elisena and Darioleta's placement of the infant Amadís in the ark in the early chapters of Amadís de Gaula. Leola's final act is to take the rest of the potion for herself, and the last lines of Leola's narration trace her imaginary transportation into the painting, where she believes she sees a young, smiling Nyneve. For Rivera-Cordero, Avalon 'symbolizes a utopia for women as well as the place of survival and creation'. ${ }^{35}$ Avalon is, after all, where the Lady of the Lake takes the mortally wounded Arthur after Salisbury. It bears remembering, however, that Arthur does not enjoy eternal life in Avalon, but rather a state of stasis that resembles death more than life.

Steinbeck and Malory, The Acts of King Arthur and His Noble Knights, 100-101.

Ibid., $1^{1-52 .}$

Montero, Historia del rey transparente, 562.

Rivera-Cordero, "El mundo fue un milagro"', 125. 
Though some critics, including Rivera Hernández, affirm the reality of Nyneve's magic, I prefer to view Nyneve as a verisimilar though exceptional woman and Avalon as a metaphor. ${ }^{36}$ If Nyneve's and Leola's lives do end in a suicide pact, there is ample literary precedent. The tragedy of the novel's end recalls Tristan and Iseult, the primitive Amadis, and Ovid's 'Pyramus and Thisbe', with one major difference: the two people who cannot live without each other are women, not entangled romantically but rather close friends and co-conspirators in a cultural rebellion. The image of female cooperation unto death, for me, cements the novel's feminism. Though Leola and Nyneve do not survive the siege of their tower, they never come under the dominion of men or Christian hegemony.

Leola, moreover, understands her life to have been a success and not a failure. As she reminds herself in the last chapter, her journey as a knight and a scholar has taken her far from her peasant origins, and she has lived a life more in accordance with her wishes and talents than she could have otherwise hoped to do. ${ }^{37}$ Montero's La historia del rey transparente expands upon the promises Amadís de Gaula and other romances of chivalry made to female readers-granting female characters self-sufficiency and selfactualization through both literacy and public life. Perhaps Cervantes's Dorotea would have enjoyed going into the mercenary business, or perhaps Oriana might have excelled at teaching children to read, had they been part of Montero's romance world. Rosa Montero, whether or not her work references Amadis in any concrete way, shows that the tropes of chivalric romance can still, in the twenty-first century, provide a vehicle for narratives about the intellectual and physical emancipation of women. Perhaps Amadis's final afterlife is to disappear into the tapestry of the neomedieval, its shadowy presence a reminder that chivalric romance has not just recently become allied with feminism; the building blocks for feminist readings of chivalry were always there.

\section{Chivalry is Dead, Long Live Chivalry}

Throughout this book, Amadis has served as the emblem of the durability of chivalric fiction, whether in the form of citation, imitation, or distant literary memory. The primitive Amadís has no clear origin, and the literary relevance of Montalvo's Amadis de Gaula has no clear end. Amadís has been 
rewritten for many purposes in many cultural moments, not all of which have been chronicled in these pages. In the Spain of the Catholic Kings, Amadis celebrated the spirit of an emerging nation and the values of its aristocracy. Importantly for this book, Amadis showed its early Castilian readers that women could use reading and writing to circumvent traditional restrictions on their behavior. For Beatriz Bernal, Amadís became an authority she could appropriate and use as a mask for her own narrative voice. For Cervantes, Amadis spoke to the past, but also to the future, primarily through the story it could tell about how readers reacted to the democratizing forces of print.

As this book has shown, women are key to the afterlives of Amadis and other early modern romances. Women were part of the readership for Amadis from the time of its first circulation, and as Bernal and Montero illustrate, the romance of chivalry became a genre in which women could write their own imaginary pasts, presents, and futures. Though men, of course, could see visions of their ideal selves in romances of chivalry, this book has suggested that there is a link between the inscribed female readers of chivalry- the literate women depicted within the texts - and the real readers in the world outside who responded to their activities. Amadís de Gaula and the works that draw inspiration from it embolden literate women, showing them that they are as much a part of the audience for fiction as men. Even the most recent visions of chivalric romance, like Rosa Montero's, dramatize the struggle between men and women over narrative authority. Yet there are few enduring victories, even in neomedieval novels, for chivalry's female characters. While chivalric romance offers a format for the development the authorial powers of women, both within the narratives and outside them, it also serves as a reminder that there is distance left to travel, whether in the early modern world or ours. 


\section{Bibliography}

Aguilar Perdomo, María del Rosario. 'La penitencia de amor caballeresca: Lisuarte, Florambel, Felixmarte y otros enfermos de amor'. In Fechos antiguos que los cavalleros en armas passaron. Estudios sobre la ficción caballeresca, edited by Julián Acebrón Ruíz, 125-50. Lleida: Universitat de Lleida, 2001.

Aladro-Font, Jorge, and Ricardo Ramos Tremolada. 'Ausencia y presencia de Garcilaso en el Quijote'. Cervantes: Bulletin of the Cervantes Society of America 16, no. 2 (1996): 89-106.

Alcalá Galán, Mercedes. 'Las piernas de la duquesa: Praxis médica y claves hermenéuticas en el Quijote de 1615'. Cervantes: Bulletin of the Cervantes Society of America 33, no. 2 (2013): 11-47.

Aldebrandin. Le régime du corps de maître Aldebrandin de Sienne : texte français du XIIIe siècle, publié pour la ıre fois, d'après les manuscrits de la Bibliothèque nationale et de la Bibliothèque de l'Arsenal. Edited by Louis Landouzy and Roger Pépin. Paris: H. Campion, 1911.

Alfonso X el Sabio. The Lapidary of King Alfonso X The Learned. Edited by Katherine Gyékényesi Gatto. New Orleans: University Press of the South, 1997.

Allen, John Jay. Don Quixote, Hero or Fool? A Study in Narrative Technique. Gainesville: University of Florida Press, 1969.

Altman, Janet. Epistolarity: Approaches to a Form. Columbus: Ohio State University Press, 1982. Alvar, Carlos. El Rey Arturo y su mundo: Diccionario de mitología artúrica. Madrid: Alianza, 1991.

—. 'La Materia de Bretaña'. In Amadís de Gaula, 1508: Quinientos años de libros de caballerías, edited by José Manuel Lucía Megías, 19-46. Madrid: Biblioteca Nacional de España, 2008.

Anderson, Ben. 'Becoming and Being Hopeful: Towards a Theory of Affect'. Environment and Planning D: Society and Space 24, no. 5 (1 October 2006): 733-52.

Ariosto, Ludovico. Orlando Furioso. Translated by Barbara Reynolds. Harmondsworth: Penguin, 1975. Arriaga, Mercedes. Desde Andalucía: Mujeres del Mediterráneo. Sevilla: Arcibel Editores, 2006. Austin, J. L. How to Do Things with Words. 2nd ed. Cambridge: Harvard University Press, 1975.

Avalle-Arce, Juan Bautista. El Amadís primitivo y el de Montalvo. México: Fondo de Cultura Económica, 1990.

Bakhtin, M. M. The Dialogic Imagination: Four Essays. Edited by Michael Holquist. Austin: University of Texas Press, 1981.

Bamford, Heather. 'Fragment as Phenomenon and Philological Subject: Two Cases of Chivalric Binding Fragments'. La corónica: A Journal of Medieval Hispanic Languages, Literatures, and Cultures 39, no. 2 (Spring 2011): 29-6o.

Baranda Leturio, Nieves. 'L'éducation des femmes dans l'Espagne post-tridentine'. In Genre et identités aux Pays-Bas méridonaux: L'éducation religeuse des femmes après le concile de Trente, edited by Silvia Mostaccio, 29-63. Louvain-la-Neuve: Academia Bruylant, 2010.

—. 'Women's Reading Habits: Book Dedications to Female Patrons in Early Modern Spain'. In Women's Literacy in Early Modern Spain and the New World, edited by Anne J. Cruz and Rosilie Hernández, 19-40. Burlington, VT: Ashgate, 2011.

Barella, Julia. 'Atardece en la casa de placer: de duquesas, dueñas y doncellas'. In El Quijote en clave de mujer/es, edited by Fanny Rubio, 257-81. Madrid: Editorial Complutense, 2005.

Barthes, Roland. Image, Music, Text. Translated by Stephen Heath. New York: Hill and Wang, 1977. Bassnett, Susan. Translation Studies. 3rd ed. London: Routledge, 2002.

Beebee, Thomas O. Epistolary Fiction in Europe, 1500-1850. Cambridge: Cambridge University Press, 1999. 
Benson, Pamela. The Invention of the Renaissance Woman: The Challenge of Female Independence in the Literature and Thought of Italy and England. University Park: Pennsylvania State University Press, 1992.

Bergmann, Emilie. 'The Exclusion of the Feminine in the Cultural Discourse of the Golden Age: Juan Luis Vives and Fray Luis de León'. In Religion, Body and Gender in Early Modern Spain, edited by Alain Saint-Saëns, 124-36. San Francisco: Mellen Research University Press, 1992.

Bernal, Beatriz. Comiença la historia de los invitos y magnanimos cavalleros don Cristalián de España, príncipe de Trapisonda, y del infante Luzescanio, su hermano, hijos del famosíssimo emperador Lindedel de Trapisonda. Valladolid: Juan Villaquirán, 1545.

—. Cristalián de España. Edited by Jodi Growitz. Newark: Juan de la Cuesta, 2014.

Bernárdez-Robal, Asunción. 'Las mujeres lectoras en el Quijote'. In El Quijote en clave de mujer/ es, edited by Fanny Rubio. Madrid: Editorial Complutense, 2005.

Bernis Madrazo, Carmen. 'El traje de la duquesa cazadora tal como lo vio Don Quijote'. Revista de dialectología y tradiciones populares 43 (1988): 59-66.

Booth, Wayne C. The Rhetoric of Fiction. Chicago: University of Chicago Press, 1961.

Bourdieu, Pierre. Distinction: A Social Critique of the Judgement of Taste. Cambridge, Mass: Harvard University Press, 1984.

Brennan, Teresa. The Transmission of Affect. Ithaca: Cornell University Press, 2004.

Brownlee, Marina Scordilis. The Severed Word: Ovid's Heroides and the Novela Sentimental. Princeton: Princeton University Press, 1990.

Burns, E. Jane. 'Courtly Love: Who Needs It? Recent Feminist Work in the Medieval French Tradition'. Signs 27, no. 1 (2001): 23-57.

Burton, Gideon. 'From Ars Dictaminis to Ars Conscribendi Epistolis: Renaissance Letter-Writing Manuals in the Context of Humanism'. In Letter-Writing Manuals and Instruction from Antiquity to the Present: Historical and Bibliographic Studies, edited by Carol Poster and Linda C. Mitchell, 88-101. Columbia: University of South Carolina Press, 2007.

Butler, Judith. Gender Trouble: Feminism and the Subversion of Identity. New York: Routledge, 1999.

- . 'Performative Acts and Gender Constitution: An Essay in Phenomenology and Feminist Theory'. Theatre Journal 40, no. 4 (1988): 519-31.

—. The Psychic Life of Power: Theories in Subjection. Redwood City: Stanford University Press, 1997.

Cacho Blecua, Juan Manuel. Amadís: heroísmo mítico cortesano. Madrid: Cupsa, 1979.

—. 'Introducción a los gestos afectivos y corteses en el Amadís de Gaula'. In Amadís y sus libros: 50o años, 55-93. México: Colegio de México, 2009.

Calvo, Juan. Primera y segunda parte de la Cirugia vniuersal, y particular del cuerpo humano que trata de las cosas naturales, no naturales, y preternaturales y de el Antidotario, en el qual se trata de la facultad de todos los medicamentos segun Galeno: añadidos tres tratados, vno de Anatomia, y otro de Morbo Galico del mismo autor, con otro de Fracturas y Dislocaciones por Andrès de Tamayo. Madrid: Antonio Gonçalez de Reyes, 1674.

Camargo, Martin. Ars dictaminis, ars dictandi. Turnhout: Brepols, 1991.

Casalduero, Joaquín. Sentido y forma del Quijote. Madrid: Ínsula, 1970.

Cascardi, Anthony J. Cervantes, Literature, and the Discourse of Politics. Toronto: University of Toronto Press, 2012.

Cátedra, Pedro M., and Anastasio Rojo Vega. Bibliotecasy lecturas de mujeres, siglo XVI. Salamanca: Instituto de Historia del Libro y de la Lectura, 2004.

Cervantes de Salazar, Francisco. 'Introducción y camino para la sabiduría, donde se declara que cosa sea y se ponen grandes avisos para la vida humana, compuesta en latin por el excelente varon Luys Vives, y buelta en Castellano con muchas adiciones que al propósito hacían por Francisco Cervantes de Salazar'. In Obras que Francisco Cervantes de Salazar ha hecho glosado y traduzido. Alcalá de Henares: Joán de Brócar, 1546. 
Cervantes Saavedra, Miguel de. Don Quixote. Translated by Edith Grossman. New York: Harper Collins, 2003 .

—. El ingenioso hidalgo don Quijote de la Mancha. Edited by L. A. Murillo. 2 vols. Madrid: Castalia, 1978 .

Chartier, Roger. The Author's Hand, the Printer's Mind. Translated by Lydia G. Cochrane. Cambridge: Polity Press, 2014.

- The Order of Books: Readers, Authors and Libraries in Europe Between the Fourteenth and Eighteenth Centuries. Translated by Lydia G. Cochrane. Redwood City: Stanford University Press, 1994.

Chatman, Seymour Benjamin. Story and Discourse: Narrative Structure in Fiction and Film. Ithaca, N.Y: Cornell University Press, 1978.

Chevalier, Maxime. Lectura y lectores en la España del siglo XVI y XVII. Madrid: Ediciones Turner, 1976.

Cixous, Hélène. 'The Laugh of the Medusa'. Translated by Keith Cohen and Paula Cohen. Signs 1, no. 4 (1976): 875-93.

Cohen, Jeffrey Jerome. Of Giants: Sex, Monsters, and the Middle Ages. Minneapolis: University of Minnesota Press, 1999.

Collet, Olivier, and Pierre-Marie Joris, eds. Partonopeus de Blois. Paris: Le Livre de Poche, 2005.

Corley, Corin, trans. Lancelot of the Lake. Oxford: Oxford University Press, 2008.

Covarrubias Horozco, Sebastián de. Tesoro de la lengua castellana. Madrid: Luis Sánchez, 1611. http://fondosdigitales.us.es.

Cravens, Sydney. 'Feliciano de Silva and His Romances of Chivalry in Don Quijote'. INTI 7 (1998): 28 -34.

Cruz, Anne J. 'Don Quijote, la duquesa, y la crisis de la aristocracia'. In USA Cervantes: 39 Cervantistas en Estados Unidos, edited by Georgina Dopico Black and Francisco Layna Ranz, 369-88. Madrid: Ediciones Polifemo, 2009.

—. 'Dorotea's Revenge: Sex and Speech Acts in Don Quijote, Part I'. Bulletin of Hispanic Studies 82 , no. 5 (2005): 615-32.

—. 'Introduction'. In Women's Literacy in Early Modern Spain and the New World, edited by Anne J. Cruz and Rosilie Hernández, 1-18. Burlington, VT: Ashgate, 2011.

—. 'Reading over Men's Shoulders: Noblewomen's Libraries and Reading Practices'. In Women's Literacy in Early Modern Spain and the New World, edited by Anne J. Cruz and Rosilie Hernández, 41-58. Burlington, VT: Ashgate, 2011.

Cuesta Torre, María Luzdivina. 'De combates interrumpidos y manuscritos incompletos: En torno a Quijote I: 8-9 y los libros de caballerías'. Bulletin of Hispanic Studies 84, no. 5 (2007): 553-71.

—. 'La realidad histórica en la ficción de los libros de caballerías'. In Libros de caballerías (de Amadís al Quijote): Poética, lectura, representación e identidad, edited by Eva Belén Carro Carvajal, Laura Puerto Morro, and María Sánchez Pérez, 87-109. Salamanca: SEMYR, 2001.

Dante Alighieri. The Divine Comedy of Dante Alighieri: Inferno. Edited and translated by Robert M. Durling. New York: Oxford University Press, 1996.

Daybell, James, and Andrew Gordon. 'Living Letters: Re-Reading Correspondence and Women's Letters'. In Women and Epistolary Agency in Early Modern Culture, 1450-1690, edited by James Daybell and Andrew Gordon, 18-38. Abingdon: Routledge, 2016.

De Armas, Frederick A. 'Captured in Ekphrasis: Cervantes and Ovid'. In Approaches to Teaching the Works of Ovid and the Ovidian Tradition, edited by Barbara Weiden Boyd and Cora Fox. New York: Modern Language Association of America, 2010.

—. 'Cervantes and the Italian Renaissance'. In Cambridge Companion to Cervantes, edited by Anthony J. Cascardi. Cambridge: Cambridge University Press, 2002.

-. The Invisible Mistress: Aspects of Feminism and Fantasy in the Golden Age. Charlottesville: Biblioteca Siglo de Oro, 1976. 
De Certeau, Michel. 'Reading as Poaching'. In Readers and Reading, edited by Andrew Bennett, 150-63. London; New York: Longman, 1995.

De Lauretis, Teresa. Technologies of Gender: Essays on Theory, Film, and Fiction. Bloomington: Indiana University Press, 1987.

Dudley, Edward. “ ‘O más dura que mármol a mis quexas!" Presencia intertextual de Garcilaso en La Galatea de Cervantes'. In Literatura y pensamiento en España: Estudios en honor de Ciriaco Morón Arroyo, edited by Francisco LaRubia-Prado, 15-32. Newark: Juan de la Cuesta, 2003.

Eco, Umberto. Travels in Hyper Reality: Essays. Translated by William Weaver. San Diego: Harcourt Brace Jovanovich, 1986.

Eisenberg, Daniel. Romances of Chivalry in the Spanish Golden Age. Newark:Juan de la Cuesta, 1982.

El Saffar, Ruth S. Beyond Fiction: The Recovery of the Feminine in the Novels of Cervantes. Berkeley: University of California Press, 1984.

Enterline, Lynn. The Tears of Narcissus: Melancholia and Masculinity in Early Modern Writing. Redwood City: Stanford University Press, 1995.

Entwistle, William J. The Arthurian Legend in the Literatures of the Spanish Peninsula. New York: Phaeton Press, 1975.

Erauso, Catalina de. Lieutenant Nun: Memoir of a Basque Transvestite in the New World. Edited by Michele Stepto and Gabriel Stepto. Boston: Beacon Press, 1996.

Fernández Medina, Sara. 'Más allá de las palabras: Juego metafórico y travestismo en Historia del Rey Transparente de Rosa Montero'. In La incógnita desvelada: Ensayos sobre la obra de Rosa Montero, edited by Alicia Ramos Mesonero and Rosa (prologue), 83-94. New York: Peter Lang, 2012.

Flores, R. M. ‘¿Cómo iban a terminar los amoríos de Dorotea y don Fernando? Primera parte del Quijote'. Nueva Revista de Filologia Hispánica 43, no. 2 (1995): 455-75.

Fogelquist, James Donald. El Amadís y el género de la historia fingida. Madrid: Ediciones José Porrúa Turanzas, 1982.

Forcione, Alban K. Cervantes, Aristotle, and the Persiles. Princeton: Princeton University Press, 1970.

Foucault, Michel. The Archaeology of Knowledge. New York: Pantheon Books, 1972.

—. 'The Subject and Power'. Critical Inquiry 8, no. 4 (1982): 777-95.

Francomano, Emily. "Puse un sobrescripto" [I wrote a new cover]: Manuscript, Print, and the Material Epistolarity of Cárcel de amor'. Fifteenth Century Studies 36 (2011): 25-48.

Fray Luis de León. A Bilingual Edition of Fray Luis de León's La Perfecta Casada: The Role of Married Women in Sixteenth-Century Spain. Edited by John A. Jones and Javier San José Lera. Lewiston: Edwin Mellen Press, 1999.

Freund, Elizabeth. The Return of the Reader: Reader-Response Criticism. London; New York: Methuen, 1987 .

Gagliardi, Donatella. “Quid puellae cum armis?” Una aproximación a Doña Beatriz Bernal y a su Cristalián de España'. Barcelona: Universitat Autònoma de Barcelona, 2003.

—. Urdiendo ficciones: Beatriz Bernal, autora de caballerías en la España del XVI. Zaragoza: Prensas Universitarias de Zaragoza, 2010.

García, Martha. La función de los personajes femeninos en Don Quijote de la Manchay su relevancia en la narrativa. Vigo: Editorial Academia del Hispanismo, 2008.

Garst-Santos, Christine. 'Dorotea's Displacement: Performing the Possible in Early Modern Spain'. Cervantes: Bulletin of the Cervantes Society of America 31, no. 2 (2011): 51-84.

Gatto, Katherine Gyékényesi. 'Medical Views of Women in the Lapidario of Alfonso X'. In Spain's Literary Legacy: Studies in Spanish Literature and Culture from the Middle Ages to the Nineteenth Century: Essays in Honor of Joaquin Gimeno Casalduero, edited by Katherine Gyékényesi Gatto and Ingrid Bahler, 43-52. New Orleans: University Press of the South, 2005. 
Genette, Gérard. Narrative Discourse Revisited. Translated by Jane E. Lewin. Ithaca: Cornell University Press, 1988.

Gerli, E. Michael. Refiguring Authority: Reading, Writing, and Rewriting in Cervantes. Lexington: University Press of Kentucky, 1995.

Gil-Albarellos, Susana. Amadís de Gaula y el género caballeresco en España. Valladolid: Secretariado de Publicaciones e Intercambio Científico, Universidad de Valladolid, 1999.

Girard, René. Deceit, Desire, and the Novel. Translated by Yvonne Freccero. Baltimore: Johns Hopkins University Press, 1965.

—.Mensonge romantique et vérité romanesque. Paris: Grasset, 1961.

González Echevarría, Roberto. Love and the Law in Cervantes. New Haven: Yale University Press, 2005.

Gorfkle, Laura. 'The Seduction(s) of Fiction and the Gendered Reader in/of Don Quixote: Dorotea's Tale'. Revista Canadiense de Estudios Hispanicos 17, no. 2 (Winter 1993): 281-95.

Green, Monica Helen. 'Introduction'. In The Trotula: A Medieval Compendium of Women's Medicine, edited by Monica Helen Green, 1-69. Philadelphia: University of Pennsylvania Press, 2001.

-, ed. The Trotula: A Medieval Compendium of Women's Medicine. Philadelphia: University of Pennsylvania Press, 2001.

Gregg, Melissa, and Gregory J. Seigworth, eds. The Affect Theory Reader. Durham: Duke University Press, 2010.

Grieve, Patricia. 'Mothers and Daughters in Fifteenth-Century Spanish Sentimental Romance: Implications for Celestina'. Bulletin of Hispanic Studies 67, no. 4 (1990): 345-56.

Growitz, Jodi. 'Introduction'. In Cristalián de España, by Beatriz Bernal, 9-34. Newark: Juan de la Cuesta, 2014 .

Guevara, Antonio de. Relox de príncipes. Edited by Emilio Blanco. Madrid: ABL Ediciones, 1994.

Gutiérrez Trápaga, Daniel. Rewritings, Sequels, and Cycles in Sixteenth-Century Castilian Romances of Chivalry: 'Aquella Inacabable Aventura'. Melton: Boydell \& Brewer, 2017.

Harney, Michael. Kinship and Marriage in Medieval Hispanic Chivalric Romance. Turnhout: Brepols, 2001.

- 'The Spanish Lancelot-Grail Heritage'. In A Companion to the Lancelot-Grail Cycle, edited by Carol Dover, 185-94. Cambridge: D.S. Brewer, 2003.

Hathaway, Robert L. 'Dorotea, or the Narrators' Arts'. Cervantes: Bulletin of the Cervantes Society of America 13, no. 1 (1993): 109-26.

Herberay des Essarts, Nicolas, trans. Le second livre de Amadis de Gaule. Paris: Denis Janot, 1541.

Hindson, Jean. 'The Fernando-Dorotea-Cardenio-Luscinda Story: Cervantes's Deconstruction of Marriage'. Romance Languages Annual 4 (1992): 483-86.

Howe, Elizabeth Teresa. Education and Women in the Early Modern Hispanic World. Burlington, VT: Ashgate, 2008.

Iser, Wolfgang. The Implied Reader; Patterns of Communication in Prose Fiction from Bunyan to Beckett. Baltimore: Johns Hopkins University Press, 1974.

Jehenson, Miriam Yvonne. 'The Dorotea-Fernando/Luscinda-Cardenio Episode in Don Quijote: A Postmodernist Play'. MLN 107, no. 2 (1992): 205-19.

Jehenson, Yvonne. 'Masochisma versus Machismo or: Camila's Re-Writing of Gender Assignations in Cervantes's Tale of Foolish Curiosity'. Cervantes: Bulletin of the Cervantes Society of America 18, no. 2 (1998): $26-52$.

Jehle, Fred F. 'The Resurrection of Altisidora in Don Quijote'. Hispanófila 25, no. 75 (1982): 9-16. Keen, Maurice. Chivalry. New Haven: Yale University Press, 1984.

Kennedy, Elspeth. Lancelot and the Grail: A Study of the Prose Lancelot. Oxford: Clarendon Press, 1986. —, ed. Lancelot du Lac. 2 vols. Paris: Librairie Générale Française, 1991.

Krause, Virginia. Idle Pursuits: Literature and Oisiveté in the French Renaissance. Newark: University of Delaware Press, 2003. 
Kristeva, Julia. The Kristeva Reader. Edited by Toril Moi. New York: Columbia University Press, 1986. La Noue, François de. Discours politiques et militaires du seigneur de La Noue, nouvellement recueillis \& mis en lumière. Basel: F. Forest, 1587.

Lacy, Norris J., ed. Lancelot-Grail: The Old French Arthurian Vulgate and Post-Vulgate in Translation. 5 vols. New York: Garland Publishing, 1992.

—, ed. The Lancelot-Grail Reader: Selections from the Medieval French Arthurian Cycle. New York: Garland, 2000.

Larrington, Carolyne. King Arthur's Enchantresses: Morgan and Her Sisters in Arthurian Tradition. London: I.B. Tauris, 2006.

Lida de Malkiel, María Rosa. 'Arthurian Literature in Spain and Portugal'. In Arthurian Literature in the Middle Ages: A Collaborative History, edited by Roger Sherman Loomis, 405-18. Oxford: Clarendon Press, 1959.

—. Estudios de literatura española y comparada. Buenos Aires: Editorial Universitaria de Buenos Aires, 1969.

Livy. The History of Rome, Books 1-5. Translated by Valerie M. Warrior. Indianapolis: Hackett, 2006.

Lobato Osorio, Lucila. 'El auxilio a Oriana desheredada, la más revelante de todas las aventuras del Amadís de Gaula para Rodríguez de Montalvo'. In Amadís y sus libros: 500 años, 121-37. México: Colegio de México, 2009.

López de Villalobos, Francisco. The Medical Works ofFrancisco López de Villalobos, the Celebrated Court Physician of Spain. Translated by George Gaskoin. London: Churchill, 1870.

Love, Harold. The Culture and Commerce of Texts: Scribal Publication in Seventeenth-Century England. Amherst: University of Massachusetts Press, 1998.

Lucía Megías, José Manuel. 'Los cuatro libros de Amadís de Gaula y Las sergas de Esplandián: Los textos de Garci Rodríguez de Montalvo'. Edad de Oro 21 (2002): 85-116.

Luján, Pedro de. Coloquios matrimoniales. Edited by Asunción Rallo Gruss. Andalucía: Junta de Andalucía, 2010.

Lully, Jean-Baptiste, and Philippe Quinault. Amadis: Tragédie en musique. Paris: Christophe Ballard, 1684 .

Luna, Lola. 'Introducción'. In El Conde Partinuplés, by Ana Caro, edited by Lola Luna, 1-68. Kassel: Reichenberger, 1993 .

Lyons, Martyn. A History of Reading and Writing in the Western World. Houndmills, Basingstoke, Hampshire; New York: Palgrave Macmillan, 2010.

Mancing, Howard. Cervantes' Don Quixote: A Reference Guide. Westport: Greenwood Press, 2006.

—. The Chivalric World of Don Quijote: Style, Structure, and Narrative Technique. Columbia: University of Missouri Press, 1982.

Marín Pina, María Carmen. 'Beatriz Bernal, Nicóstrata y la materia troyana en el Cristalián de España'. In Amadís y sus libros: 500 años, edited by Aurelio González and Ayaxácatl Campos García Rojas, 277-302. México: Colegio de México, 2009.

—. 'Introducción'. In Primaleón, i-xxvi. Alcalá de Henares: Centro de Estudios Cervantinos, 1998.

—. 'La mujer y los libros de caballerías. Notas para el estudio de la recepción del género caballeresco entre el público femenino'. Revista de Literatura Medieval 3 (1991): 129-48.

—.Páginas de sueños: estudios sobre los libros de caballerías castellanos. Zaragoza: Institución Fernando el Católico, 2011.

Márquez Villanueva, Francisco. Personajes y temas del Quijote. Madrid: Taurus, 1975.

Martín, Adrienne Laskier. An Erotic Philology of Golden Age Spain. Nashville: Vanderbilt University Press, 2008.

Martín Romero, José Julio. 'Amadís de Gaula humanizado: vejez y melancolía en la obra de Feliciano de Silva'. Letras (Buenos Aires) 59-6o (2009): 251-62. 
-. 'Biografía heroica y concepto de nobleza en Amadís de Gaula y otros libros de caballerías'. La corónica 40, no. 2 (2012): 231-58.

Martorell, Joanot, and Martí Joan de Galba. Tirant Lo Blanc. Translated by David H. Rosenthal. Baltimore: Johns Hopkins University Press, 1984.

Massumi, Brian. 'The Autonomy of Affect'. Cultural Critique, no. 31 (1995): 83-109.

Matulka, Barbara. The Novels of Juan de Flores and Their European Diffusion: A Study in Comparative Literature. New York: New York University, 1931.

Mazzotta, Giuseppe. Cosmopoesis: The Renaissance Experiment. Toronto: University of Toronto Press, 2001.

McCracken, Peggy. The Romance of Adultery: Queenship and Sexual Transgression in Old French Literature. Philadelphia: University of Pennsylvania Press, 1998.

McGaha, Michael. 'Cervantes and Virgil'. In Cervantes and the Renaissance, edited by Michael McGaha, 34-50. Easton: Juan de la Cuesta, 1980.

Menéndez y Pelayo, Marcelino. Orígenes de la novela. Vol. 1. Madrid: Bailly y Balliere, 1925 .

Montero, Rosa. Historia del rey transparente. Barcelona: Debolsillo, 2015.

Montgomery, James T. 'Did Cervantes Learn of Avellaneda's Quijote Earlier than Chapter 59 of Part Two?' Cervantes: Bulletin of the Cervantes Society of America 30, no. 2 (2010): 11-13.

Monzó, Clara, ed. 'El Conde Partinuplés: Transcripción'. Tirant 16 (2013): 409-68.

Monzón, Francisco. Norte de idiotas compuesto y revisto por el doctor Francisco de Monçon. Lisbon: Joannes Blavio de Colonia, 1563. http://purl.pt/23144/3/\#/1

Nabokov, Vladimir. Lectures on Don Quixote. Edited by Fredson Bowers. New York: Harcourt Brace Jovanovich, 1983 .

Nieva de la Paz, Pilar. 'Modelos femeninos de ruptura en la literatura de las escritoras españolas del siglo XX: Concha Méndez (1898-1986), Carmen Martín Gaite (1925-200o) y Rosa Montero (1951- )'. In Roles de género y cambio social en la literatura española del siglo XX, edited and introduction by Pilar Nieva de la Paz, 107-31. Amsterdam: Rodopi, 2009.

Ortiz-Hernán Pupareli, Elami. 'La escritura femenina del siglo XVI y los paradigmas usados por Beatriz Bernal en Cristalián de España'. Tirant 12 (2009): 133-50.

Osorio, Miryam. 'Sexo y género en Historia del rey transparente de Rosa Montero'. Ciberletras 19 (July 2008).

Ovid. Heroides. Edited and translated by Harold Isbell. London: Penguin, 1990.

—.Metamorphoses. Translated by David Raeburn. New York: Penguin, 2004.

Park, Sidney. 'Don Cristalián de España de Beatriz Bernal: Edición Modernizada'. PhD diss., Temple University, 1981.

Paz Gago, José María. 'La noble lectora. Las lecturas caballerescas de la duquesa'. Edad de Oro 26 (2007): $175^{-83}$.

Pérez-Toribio, Montserrat. 'From Mother to Daughter: Educational Lineage in the Correspondence Between the Countess of Palamós and Estefanía de Requesens'. In Women's Literacy in Early Modern Spain and the New World, edited by Anne J. Cruz and Rosilie Hernández, 59-78. Burlington, VT: Ashgate, 2011.

Petrus Hispanus. The Treasury of Health: Containing Many Profitable Medicines, Gathered out of Hipocrates, Galen, and Auicen, by One Petrus Hyspanius \& Translated into English by Humfrie Lloyd, Who Hath Added Therevnto the Causes and Signes of Euerie Disease, with the Aphorismes of Hypocrates, and Iacobus de Partibus, Redacted to a Certaine Order According to the Members of Mans Bodie, and a Compendious Table, Containing the Purging and Confortatiue Medicines, with the Exposition of Certaine Names and Waightes in This Booke Contained, with an Epistle of Diocles Vnto King Antigonus. Translated by Humfrie Lloyd. London: Thomas East, 1585 .

Piera, Montserrat. 'Minerva y la reformulación de la masculinidad en Cristalián de España de Beatriz Bernal'. Tirant 13 (2010): 73-88. 
Piera, Montserrat, and Jodi Shearn. 'Gendering Action in Iberian Chivalric Romance'. Medieval

Feminist Forum 45, no. 1 (2009): 85-109.

Pierce, Frank. Amadís de Gaula. Boston: Twayne, 1976.

Pinet, Simone. Archipelagoes: Insular Fictions from Chivalric Romance to the Novel. Minneapolis: University of Minnesota Press, 2011.

Plamper, Jan. The History of Emotions: An Introduction. Oxford: Oxford University Press, 2015.

Porras, G. Yuri. 'El mal de amores y las canciones en las primeras dos Celestinas'. Confluencia: Revista Hispánica de Cultura y Literatura 24, no. 1 (Fall 2008): 139-51.

Quint, David. Cervantes's Novel of Modern Times: A New Reading of Don Quijote. Princeton: Princeton University Press, 2003.

—. Origin and Originality in Renaissance Literature. New Haven; London: Yale University Press, 1983 .

Reddy, William M. The Navigation of Feeling: A Framework for the History of Emotions. Cambridge: Cambridge University Press, 2001.

Redondo, Augustin. Otra manera de leer el Quijote: Historia, tradiciones culturales y literatura. Madrid: Editorial Castalia, 1998.

Rey Bueno, Mar. Quijote mágico: Los mundos encantados de un hidalgo hechizado. Madrid: Algaba Ediciones, 2005.

Rhu, Lawrence F. The Genesis of Tasso's Narrative Theory: English Translations of the Early Poetics and Comparative Study of Their Significance. Detroit: Wayne State University Press, 1993.

Ricœur, Paul. Time and Narrative. 2 vols. Chicago: University of Chicago Press, 1984.

Riquer, Martín de. Estudios sobre el Amadís de Gaula. Barcelona: Sirmio, 1987.

Rivera Hernández, Raúl Diego. 'Historia del rey transparente de Rosa Montero: Una lectura contemporánea del Medievo a partir de un viaje de aventuras'. In La incógnita desvelada: Ensayos sobre la obra de Rosa Montero, edited by Alicia Ramos Mesonero, 27-39. New York: Peter Lang, 2012.

Rivera-Cordero, Victoria. "El mundo fue un milagro": Uses of the Past and Survival in Rosa Montero's Historia del rey transparente'. Confluencia: Revista Hispánica de Cultura y Literatura 26, no. 2 (Spring 2011): 118-27.

Rivers, Elías L. 'Sancho y la duquesa: Una nota socioliteraria'. Cervantes: Bulletin of the Cervantes Society of America 11, no. 2 (Fall 1991): 35-42.

Robertson, Elizabeth. 'Medieval Medical Views of Women and Female Spirituality in the Ancrene Wisse and Julian of Norwich's Showings'. In Feminist Approaches to the Body in Medieval Literature, edited by Linda Lomperis and Sarah Stanbury, 142-67. Philadelphia: University of Pennsylvania Press, 1993.

Rodríguez de Montalvo, Garci. Amadís de Gaula. Edited by Juan Manuel Cacho Blecua. 2 vols. Madrid: Cátedra, 1987 .

—. Las sergas de Esplandián. Edited by Carlos Sainz de la Maza. Madrid: Editorial Castalia, 2003.

Rodríguez Velasco, Jesús. Order and Chivalry: Knighthood and Citizenship in Late Medieval Castile. Translated by Eunice Rodríguez Ferguson. Philadelphia: University of Pennsylvania Press, 2010.

—. 'Teoría de la fábula caballeresca'. In Libros de caballerías (de Amadís al Quijote): Poética, lectura, representación e identidad, edited by Eva Belén Carro Carvajal, Laura Puerto Morro, and María Sánchez Pérez, 343-58. Salamanca: SEMYR, 2001.

Rodríguez-Moñino, Antonio R. El primer manuscrito del Amadís de Gaula. Madrid: Silverio Aguirre Torre, 1957 .

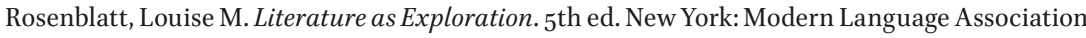
of America, 1995 . 
Rothstein, Marian. 'Clandestine Marriage and Amadis de Gaule: The Text, the World, and the Reader'. The Sixteenth Century Journal:Journal of Early Modern Studies 25, no. 4 (1994): 873-86.

- Reading in the Renaissance: Amadis de Gaule and the Lessons of Memory. Newark: University of Delaware Press, 1999.

Ruiz de Conde, Justina. El amor y el matrimonio secreto en los libros de caballerias. Madrid: Aguilar, 1948.

Ruiz Pérez, Pedro. 'La hipóstasis de Armida: Dorotea y Micomicona'. Cervantes: Bulletin of the Cervantes Society of America 15 (1995): 147-63.

Sales Dasí, Emilio José. 'Las continuaciones heterodoxas (el Florisando [1510] de Páez de Ribera y el Lisuarte de Grecia [1526] de Juan Díaz) y ortodoxas (el Lisuarte de Grecia [1514] y el Amadís de Grecia [1530] de Feliciano de Silva) del Amadís de Gaula'. Edad de Oro 21 (2002): 117-52.

Salvador Miguel, Nicasio. 'La instrucción de Isabel la Católica. Los años cruciales (1451-1467)'. Arbor 178, no. 701 (2004): 107-28.

San Pedro, Diego de. Cárcel de amor. Arnalte y Lucenda. Sermón. Edited by José Francisco Ruiz Casanova. Madrid: Cátedra, 1999.

Schevill, Rudolph. 'Ovid and the Renaissance in Spain'. Edited by Charles M. Gayley, H.K. Schilling, and Rudolph Schevill. University of California Publications in Modern Philology 4 (1913): 1-268.

Schmitz, Ryan. 'Sancho's Courtly Performance: Discreción and the Art of Conversation in the Ducal Palace Episodes of Don Quijote II'. MLN 128, no. 2 (2013): 445-55.

Schneider, Gary. The Culture of Epistolarity: Vernacular Letters and Letter Writing in Early Modern England, 1500-1700. Newark: University of Delaware Press, 2005.

Severin, Dorothy S. 'Diego de San Pedro's Arnalte y Lucenda: Subtext for the Cardenio Episode of Don Quixote'. In Studies on the Spanish Sentimental Romance (1440-1550): Redefining a Genre, edited by Joseph G. Gwara and E. Michael Gerli, 145-50. London: Tamesis, 1997.

Sharrer, Harvey L. 'The Acclimatization of the Lancelot-Grail Cycle in Spain and Portugal'. In The Lancelot-Grail Cycle: Text and Transformations, edited by William W. Kibler, 175-86. Austin: University of Texas Press, 1994.

Showalter, Elaine. 'Feminist Criticism in the Wilderness'. Critical Inquiry 8, no. 2 (Winter 1981): 179-205.

Silva, Feliciano de. Choronica del muy valiente y esforçado principe y cauallero de la ardiente espada Amadis de Grecia, hijo de Lisuarte de Grecia, Emperador de Constantinopla y de Trapisonda, $y$ Rey de Rodas que tracta de sus grandes hechos en Armas, y de sus altos, y estraños Amores: y es el noueno libro de Amadis de Gaula. Lisbon: Simón López, 1596.

- Florisel de Niquea: Cuarta parte, libros Iy II. Zaragoza: Pierres de la Floresta, 1568.

—. Florisel de Niquea (Parte III). Edited by Javier Martín Lalanda. Alcalá de Henares: Centro de Estudios Cervantinos, 1999.

Sowards, J. K. 'Erasmus and the Education of Women'. The Sixteenth Century Journal:Journal of Early Modern Studies 13, no. 4 (1982): 77-89.

Spiller, Elizabeth. 'Cervantes avant la lettre: The Material Transformation of Romance Reading Culture in Don Quijote'. Modern Language Quarterly 6o, no. 3 (1999): 295-319.

- Reading and the History of Race in the Renaissance. Cambridge: Cambridge University Press, 2011.

Steinbeck, John, and Thomas Malory. The Acts of King Arthur and His Noble Knights. New York: Avenel Books, 1982.

Stephens, Walter. Giants in Those Days: Folklore, Ancient History, and Nationalism. Lincoln: University of Nebraska Press, 1989.

Still, Judith, and Michael Worton. 'Introduction'. In Intertextuality: Theories and Practice, edited by Michael Worton and Judith Still, 1-44. Manchester: Manchester University Press, 1990. 
Suleiman, Susan Rubin. 'Introduction'. In The Reader in the Text: Essays on Audience and Interpretation, edited by Susan Rubin Suleiman and Inge Crosman Winters, 1-45. Princeton: Princeton University Press, 1980.

Tarzibachi, Susana Lidia. 'Sobre el "autor" y el "narrador" en Amadís de Gaula'. In Amadís de Gaula: Estudios sobre narrativa caballeresca castellana en la primera mitad del siglo XVI, edited by Lilia de Orduna. Kassel: Edition Reichenberger, 1992.

Tasso, Torquato. Discourses on the Heroic Poem. Translated by Mariella Cavalchini and Irene Samuel. Oxford: Clarendon Press, 1973.

—. Jerusalem Delivered. Translated by Ralph Nash. Detroit: Wayne State University Press, 1987.

Le Trésor des Amadis : Contenant les épîtres, complaintes, concions, harangues, deffis \& cartels, recueillis des douze livres d'Amadis de Gaule pour servir d'exemple à ceus qui désirent apprendre à bien écrire missives, ou parler français ([Reprod.]). Anvers: C. Plantin, 156o. http://gallica. bnf.fr/ark:/12148/bpt6k54553x.

Triplette, Stacey. 'From Guinevere to Isabel: Rodríguez de Montalvo's Transformations of Oriana in Amadís de Gaula'. La corónica: A Journal of Medieval Hispanic Languages, Literatures, and Cultures 43, no. 2 (Spring 2015): 29-55.

Vega, Lope de. La dama boba. Edited by Felipe B. Pedraza Jiménez. Madrid: Biblioteca Nueva, 2002. Vélez Quiñones, Harry. 'Barefoot and Fallen: Dorotea, Athena, Cervantes, and Homer'. Romance Quarterly 52, no. 4 (2005): 281-93.

Venegas, Alexio. 'Prólogo al lector. El maestro Alexio Venegas al benigno y pío lector'. In Apólogo de la ociosidad y el trabajo, by Francisco Cervantes de Salazar and Luis Mexía, edited by Consolación Baranda, 77-86. Salamanca: Ediciones Universidad de Salamanca, 2012.

Vicente, Gil. Tragicomedia de Amadís de Gaula. Edited by T. P. Waldron. Manchester: Manchester University Press, 1959.

Vickers, Nancy. 'Diana Described: Scattered Woman and Scattered Rhyme'. Critical Inquiry 8, no. 2 (1981): 265-79.

Villamandos, Alberto. 'De Dorotea a Micomicona (“Quijote” I: 28-29): Lecturas prohibidas y máscaras textuales'. Cuadernos Cervantes de la lengua española 11, no. 56 (2005): 14-22.

Vives, Juan Luis. The Education of a Christian Woman: A Sixteenth-Century Manual. Translated by Charles Fantazzi. Chicago: University of Chicago Press, 2000.

Vogeley, Nancy. 'How Chivalry Formed the Myth of California'. Modern Language Quarterly: A Journal of Literary History 62, no. 2 (June 2001): 165-87.

Vollendorf, Lisa. 'Cervantes and His Women Readers'. Romance Quarterly 52, no. 4 (October 2005): 312-27.

Ward, Jennifer C. Women in Medieval Europe, 1200-1500. London: Longman, 2002.

Weissberger, Barbara F. Isabel Rules: Constructing Queenship, Wielding Power. Minneapolis: University of Minnesota Press, 2004.

—. 'The Gendered Taxonomy of Spanish Romance'. La corónica: A Journal of Medieval Spanish Language and Literature 29, no. 1 (2000): 205-29.

Weruaga Prieto, Ángel. 'La lectura femenina en la Salamanca moderna'. In La memoria de los libros. Estudios sobre la historia del escrito y de la lectura en Europa y América, 2: 145-57. Salamanca: Instituto de Historia del Libro y de la Lectura, 2004.

Whinnom, Keith. 'Introducción'. In Obras Completas I: Tractado de amores de Arnalte y Lucenda, 9-84. Madrid: Castalia, 1973.

Whitenack, Judith. 'Don Quixote and the Romances of Chivalry Once Again: Converted Paganos and Enamoured Magas'. Cervantes: Bulletin of the Cervantes Society of America 13, no. 2 (1993): 61-91.

—. "'Emphasis Added”: An Introduction to Beatriz Bernal's Cristalián de España'. Revista Monográfica 13 (1997): 24-38. 
Williamson, Edwin. The Half-Way House of Fiction: Don Quixote and Arthurian Romance. New York: Oxford University Press, 1984.

Wilson, Diana de Armas. Cervantes, the Novel, and the New World. Oxford: Oxford University Press, 2003.

Worden, William. 'Cervantes Transforms Ovid: The Dubious Metamorphoses in Don Quixote'. In Ovid in the Age of Cervantes, edited by Frederick A. De Armas, 116-36. Toronto: University of Toronto Press, 2010.

Zimic, Stanislav. Los cuentos y las novelas del Quijote. Madrid: Iberoaméricana Veruvert, 1998. 



\section{Index}

Abelard, Peter: 188

adaptation: $12-16,34,153,188$

agency: $13,35-40,42,61-63,69,76,81,95$, 104-105, 114, 117, 120, 134, 151, 154, 16o, 185-186, 190

Aguilar Perdomo, María: 13, 45, 65, 105

Alcalá Galán, Mercedes: 156, 165

Aldobrandino de Siena, Le régime du corps: 47-48

Alfonso X el Sabio, Lapidario: 48

Allen, John Jay: 148, 159

Altman, Janet: 50-51, 128-129

Alvar, Carlos: 41,74

Amadís de Gaula: see Montalvo, Garci Rodríguez de

Amazon: 27, 33, 85, 89

Anderson, Ben: 43

Ariosto, Ludovico, Orlando Furioso: 18, 40, 96, $146,156,161,165,190$

Aristotle: 46,147

Arriaga, Mercedes: 47

ars dictaminis: $38,52,63,65-69,72,107-108$, 111-113, 123

Arthurian legend: $18,20,40,41,44,56,63,65$, $69,79,91,97,156,188-189,195^{-196}$

Austin, J.L.: 63

Avalle-Arce, Juan Bautista: 13, 17, 20, 41, 45, 52, $63-64$

Avellaneda, Fernández de: 40, 179-183

Bakhtin, Mikhail: 34

Bamford, Heather: 18

Baranda Leturio, Nieves: 22-24

Barella, Julia: 157, 163-164

Barthes, Roland: 34

Bassnett, Susan: 87

Beebee, Thomas: $37,5^{2}, 124$

Benson, Pamela: 27-28, 131

Bergmann, Emilie: 15

Bernal, Beatriz

author's background: 12, 23-24, 32, 81-83

Cristalián de España: 13, 38-39, 81-115

Bernárdez-Robal, Asunción: 23, 155

Bernis Madrazo, Carmen: 163

Boccaccio, Giovanni, De Mulieribus Claris: 27, 92,131

Boiardo, Matteo, Orlando Innamorato: 146

Booth, Wayne: 28

Bourdieu, Pierre: 36

Bradley, Marion Zimmer: 186

Brennan, Teresa: $5^{0}$

Brownlee, Marina: 51-52, 67, 126

Burns, E. Jane: 62, 69, 113

Burton, Gideon: 66

Butler, Judith: 36-37, 63, 135, 190
Cacho Blecua, Juan Manuel: 41, 53

Calvo, Juan: 47, 57

Cano, Melchor: 19

Casalduero, Juan: 143

Cascardi, Anthony: 147, 169

Castro, Guillén de: 153

Cátedra, Pedro: 22, 82, 136

Catherine of Aragon: 135

Catholic Kings (Isabel and Fernando): 41, 45, 198

Cervantes, Miguel de

Don Quixote: $39-40,117-183$

Altisidora: 40, 154-157, 160-161, 170-183

Cardenio: 13-14, 39, 118-133

chivalry: 20-21

El curioso impertinente: 127,131

Don Quixote's literary fame: 153-154

Dorotea: 24, 39, 117-119, 133-152, 154, 157, 16o-162, 175, 178, 182, 191, 197

the duchess: $39,117,154-171,177-178,181-183$

Dulcinea: 135-138, 156, 16o-161, 166-169, 172-174

Fernando: 119-120, 123, 127-133, 137-141, 144, $148-152,160,172$

Luscinda: 13, 30, 39, 117-137, 150-152, 154, 157, $168,182,193$

Maritornes and the innkeeper's daughter: 39, 118-119, 157, 159-161

Micomicona: 39, 141-151

Teresa Panza: 168-169

Cervantes de Salazar, Francisco: 12

Chartier, Roger: 28, 102, 155

Chatman, Seymour: 29

Chevalier, Maxime: 16-17, 23, 81, $15^{8}$

childbirth: $38,42,47-50,56-58$

chivalric romance: 18-21, 41-42, 81, 117, 137-142, $153,158-159,166-167,178,186,188,194-195$

Chrétien de Troyes: author: 188-189

Le chevalier de la charrette: 74

Cixous, Hélène: 84

clandestine marriage: $44,54-56,137-141,149-15^{2}$

Cohen, Jeffrey Jerome: 142

conduct books: $12,25,31-32,35,39,46,48-50$ $118,124,135-137,170,174-175,181-182$

courtly love: $11,44,61-62,68-69,89,105,113$, 129,188

Covarrubias, Sebastián de: 143, 149

Cravens, Sydney: 81

Cristalián de España: see Bernal, Beatriz

La crónica troyana: $24,38,81,92$

Cruz, Anne J.: 22-24, 36, 137, 139, 141, 143-144, 151, $153,163-164$

Cuesta Torre, María Luzdivina: 11, 45, 87 
Dante Alighieri, Inferno: 40, 157, 176, 179-181

Daybell, James: 36

De Armas, Frederick: 94, 121, 145, 148, 163

De Certeau, Michel: 29

defense of women: 28

Díaz, Juan: 39, 79, 81, 87

Don Quixote: See Cervantes, Miguel de

Dudley, Edward: 179

Eco, Humberto: 186

Eisenberg, Daniel: 13, 15, 20-21, 41-42, 45, 117, 158,160

El conde Partinuplés: see Partonopeus de Blois

El Saffar, Ruth: 148

Eleanor of Acquitane: 188

Elizabeth I: 17

emotion: $11,31-32,37-38,40,43,46-52,55^{-6} 7,72$, $86,88,99,105,107-108,110-112,122-127,130$, $137,140,154,168,186,191-196$

Enterline, Lynn: 147

Entwistle, William J.: 20, 41, 56

epistolary fiction: $37,43,50-53,64-68,122,124$, 126-128

Erasmus: 48, 135, 175-176

Erauso, Catalina de: $190-191$

eroticism: 13, 31, 67, 89, 107, 109, 114, 118, 122, 161, 175

Espejo de príncipes y caballeros: 156

Felipe II: 16, 19, 23, 117

Fernández de Oviedo, Gonzalo, Claribalte: 87

Fernández Medina, Sara: 187

Flores, Robert M.: 144

Fogelquist, James Donald: 146

Forcione, Alban K.: 146-147

Foucault, Michel: 33,36

Francomano, Emily: 50, 59, 129

Freund, Elizabeth: 29

Fuentes, Alonso de: 19

Gagliardi, Donatella: 12, 22, 24, 31-32, 82-83, 86, 89, 91-93

Galen: $37,46-47,62,67$

García, Martha: 151, 157, 164, 170

Garcilaso de la Vega: 40, 157, 173, 179, 183

Garst-Santos, Christine: 134, 136, 175

Gatos, Juana de (daughter of Beatriz Bernal): $82-83$

Gatto, Katherine: 46

Genette, Gérard: 30

Gerli, E. Michael: 119-120

Gil-Albarellos, Susana: 18, 41

Girard, René: 20, 117

González Echevarría, Roberto: 167

Gordon, Andrew: 36

Gorfkle, Laura: 142, 151

Green, Monica Helen: 46-47

Gregg, Melissa: 43

Grieve, Patricia: 15, 51-52
Growitz, Jodi: $24,32-33,83,88,110$

Guevara, Antonio de, Relox de príncipes: 19, 49, $57,82,92$

Gutiérrez Trápaga, Daniel: 18-19, 35

Harney, Michael: 18, 21, 41, 44, 49, 54, 140

Hathaway, Robert: 144

Heliodorus, Ethiopian History: 134, 142, 145

Héloise: 188, 192

Henri II: 16

Herberay, Nicolas de: 14, 16, 52, 79

Herrade de Landsberg, Hortus Deliciarum: 188, 191-192

Hindson, Jean: 54, 141

Hippocrates: 46

Howe, Elizabeth Teresa: 174

humoral theory: $38,46-48,67,165$

ideal reader: $28-29,182$

imitation: 12, 15-16, 20, 31, 33-34, 37, 39-40, 44, $66,79,82,105,109,117,119,120-122,127,130$, 133-135, 141, 148, 153-155, 157, 159-16o, 164, 168, 182, 192, 197

implied reader: 29-30, 158

inscribed reader: $30,33,39,51,53,59,63,69,76$, $118-119,127,171,179,193,196$

interlace: 14,41

intertextuality: $22,28,33-35,38,53,81-82$, $85,87-88,93,98-99,105,127,131,157,162$, $178-179,185^{-186}, 192,195$

Isabel de Valois: 23

Isabel la Católica: 11, 23, 25, 64, 174

Iser, Wolfgang: 29-30

Janot, Denis: 14

Jehenson, Miriam Yvonne: 31, 119, 151

Jehle, Fred F.: 179, 182

Keen, Maurice: 138

Kennedy, Elspeth: 74, 98

Krause, Virginia: 17

Kristeva, Julia: 34

Lancelot: $18,40,41,44,53,62-63,65-66,69,74$, $87,89,91,96,98,106,109,121,138,161,172$, $176,189,195$

Larquié, Claude: 22

Larrington, Carolyne: 165

Lauretis, Teresa de: 26-27

Lerner, Gerda: 15

letters: 11- $16,22,24,30,36-38,43,46,50-53,5^{8-}$ 79, 105-114, 122-133, 135-137, 166, 168-169, 175

Lida de Malkiel, María Rosa: 16, 18, 41, 44, 121

literacy: 11-13, 22-25, 28, 30, 32, 37, 42, 53, 61, $64-65,74,78-79,84-85,88,91,97,106,114$, $118,129,135^{-136,155, ~ 158, ~ 162, ~ 170, ~ 186, ~ 188, ~}$ 190, 192-193, 197

Livy: 131

Lobato Osorio, Lucila: 11, 45 
Lope de Vega, La dama boba: 24

López de Villalobos, Francisco: 47

Louis XIV: 16

Love, Harold: 60

Lucía Megías, José Manuel: 13, 41, 45, 157

Luis de Granada, Fray: 19

Luis de Leon, Fray. La perfecta casada: 32, 134-135, 175

Luján, Pedro de

Coloquios matrimoniales: 48-49, 135, 140, 143

Silves de la selva: 39, 79, 81, 135

Lully, Jean-Baptiste: 14, 17

Luna, Álvaro de, Libro de las claras y virtuosas mugeres: 27,92

Luna, Lola: 93,163

Lyons, Martyn: 28-29

Malon de Chaide, Fray Pedro: 19

Malory, Sir Thomas, Le Morte D'Arthur: 18, 188, 194,196

Mancing, Howard: 20, 41, 153, 164

Marie de Champagne: 188

Marie de France: 188-189

Marín Pina, María Carmen: 17, 22-24, 50-51, 63, $85,92,110,122$

Márquez Villanueva, Francisco: 143-144

Martín Romero, José Julio: 42, 79

Martín, Adrienne: 118

Martorell, Joanot, Tirant lo Blanch: 15, 24, 38, 51, $81-82,99,105,106,110-112$

Massumi, Brian: 43

matter of Britain (see Arthurian legend)

matter of France: 18

matter of Rome: 18

Matulka, Barbara: 56

Matute, Ana María: 186

Mazzotta, Giuseppe: 156

McCracken, Peggy: 44

McGaha, Michael: 132

Menéndez y Pelayo, Marcelino: 19, 32, 83-84, 176

Mexía, Pedro: 19

Montalvo, Garci Rodríguez de:

author's background: 11, 16, 41

Amadís de Gaula: 11-24, 38, 41-79, 81-82, 84, 86-87, 89-91, 96-98, 105-110, 117-118, 120-126, 130-131, 139-141, 150-151, 153-154, $156-157,165,168,171-172,176,178,185$, 188-190, $196-198$

Las sergas de Esplandián: 17, 24, 38, 44, 52, $54,61,73,79,81,87,90-91,96,106,110$, 143,178

Montero, Rosa, La historia del rey transparente: $21,35,40,185^{-197}$

Montgomery, James T.: 179

Monzó, Clara: 93, 162-163

Monzón, Francisco de: 25

Munday, Anthony: 14, 79
Nabokov, Vladimir: 153, 160

narratology: 28,30

Nieva, Pilar: 187

Noue, François de la: 16

Ortiz-Hernán Pupareli, Elami: 82

Osorio, Myriam: 190

Ovid:

Heroides: 30, 38-39, 52, 63, 66-69, 72, 119, $122,130,132$

Metamorphoses: 39, 119-122

Páez de Ribera, Ruy, Florisando: 39, 51, 79, 81, 90

Palmerín de Oliva: 15,24

Paris, Gaston: 62

Park, Sidney: 83, 113

Partonopeus de Blois (El conde Partinuplés): 93-94, 162-163

Paz Gago, José María: 23, 157-158

Pérez-Toribio, Montserrat: 168

Petrarca, Francesco (Petrarch): 157, 172-174

Petrus Hispanus, Thesaurus Pauperum: 47, 55-57

Piera, Montserrat: 24, 32-33, 42, 82, 86, 88, 91, 110

Pierce, Frank: 20, 41, 45, 73

Pinet, Simone: 21, 42, 68

Pizan, Christine de, The City of Ladies: 27, 92

Plamper, Jan: $38,43,62$

Porras, George Yuri: 49

pregnancy: 46-50, $55-58$

primitive Amadis: 20, 24, 41, 44, 140, 197

prophecy: 73-79, 91, 100, 104, 168

Quint, David: $34,42,68,125,127,131,148,151$, 153,163

reader-response theory: 30

reading: $28,42,84-85,101,105,115,117-119,122$, $127,134-135,151-160,187-188,190-192,195-196$ reception studies: 28

Reddy, William: 63, 195

Redondo, Augustin: 144, 158

Rey Bueno, Mar: 156

Rhu, Lawrence F: 146-147

Ricœur, Paul: 129

Riquer, Martín de: 18, 20, 41

Rivera Hernández, Raúl Diego: 189, 197

Rivera-Cordero, Victoria: 187, 190, 193, 196

Rivers, Elias: 167

Robertson, Elizabeth: 46

Rodríguez del Padrón, Juan: El bursario: $66-67$

Siervo libre de amor: $5^{1}$

Rodríguez Moñino, Antonio: 19

Rodríguez Velasco, Jesús: 12, 21, 42, 138-139, $15^{8}$

Rojas, Fernando de. La Celestina: 31-32, 49, 51, 82

Rojo, Anastasio: 22, 82, 136 
romance of chivalry: see chivalric romance Rosenblatt, Louise: 28

Rothstein, Marian: 16-17, 21-22, 28, 30, 44, 56 Ruiz de Conde, Justina: 45, 54-55, 137, 141

Ruiz Pérez, Pedro: 145

Sainz de la Maza, Carlos: 143

Sales Dasí, Emilio José: 81

Salvador Miguel, Nicasio: 64

San Pedro, Diego de:

Arnalte y Lucenda: 39, 51-52, 126-129, 137

La cárcel de amor: 31, 39, 50-51, 126-130, 134

Schevill, Rudolph: 121

Schmitz, Ryan: 153

Schneider, Gary: 60

Segura, Juan de, Proceso de cartas: $5^{2}$

Seigworth, Gregory J.: 43

sentimental novel: $18-19,35,38,50-52,65,67$,

$107,119,122,126-130,134,137$

Severin, Dorothy: 126-127

Sharrer, Harvey L: 18, 41

Shearn, Jodi (see Growitz, Jodi)

Showalter, Elaine: 14-15, 84

Silva, Feliciano de: $39,51,79,81-82,92,143,156$ Amadis de Grecia: 87, 99

Florisel de Niquea Part I: 82

Florisel de Niquea Part III: 143

Florisel de Niquea Part IV: 79, 164, 171, 175

Sowards, J.K.: 135, 175-176

Spiller, Elizabeth: 21-22, 31, 51, 106-107, 117-118, $123,126-127,176$

Steinbeck, John, The Acts of King Arthur and his Noble Knights: 188, 194, 196

Stephens, Walter: 142

Still, Judith: 34-35

Suleiman, Susan: 30

Tapia, Serafín de: 22

Tarzibachi, Susana Lidia: 41

Tasso, Bernardo, Amadigi di Gaula: 16
Tasso, Torquato:

Gerusalemme Liberata: 96, 119, 142, 145-146, 161-163

Discorsi sul poemma eroico: 146-147

Gerusalemme Conquistata: 146

Teresa of Ávila, St.: 22-23

translation: $12,14,16,23,30,34,66-67,79,83,87$, $93,94,121,127,162$

Trésor de L'Amadis de Gaule: 14, 17

Triplette, Stacey: 11, 45

Tristan and Isolde: 44, 51, 197

Trotula: 47-48

Tyler, Margaret: 32

Velez Quiñones, Harry: 144

Venegas, Alexio de: 19, 176

verba de praesenti marriage (see clandestine marriage)

Vicente, Gil: 14, 16

Vickers, Nancy: 172-173

Villamandos, Armando: 134

Virgil, Aeneid: 40, 132, 156-157, 178

Vives, Juan Luis: 19, 31-32, 51, 134-135, 174

Vogeley, Nancy: 17

Vollendorf, Lisa: 22-23, 118, 159

Wace, Roman de Brut: 195

Ward, Jennifer C.: 47

Weissberger, Barbara F.: 19, 33, 51, 126, 159

Weruaga-Prieto, Ángel: 22

Whinnom, Keith: 51

Whitenack, Judith: 31-32, 42, 83-84, 88, 90, 157 , 161, 191

Williamson, Edwin: 20, 44, 55, 68

Wilson, Diana de Armas: 21

women's culture: 14-15, 41-42

woodcut illustrations: 25

Worden, William: 121

Worton, Michael: 34-35

Zimic, Stanislav: 120, 134 